BRIDGING THE GAP IN FRENCH ROMANTIC REPRESENTATIONS OF BLACKNESS

1750 - 1880:

THE MALE MULATTO IN FRENCH LITERATURE

A Dissertation
presented to
the Faculty of the Graduate School
at the University of Missouri - Columbia
In Partial Fulfillment
of the Requirements for the Degree
Doctor of Philosophy
Dr. Carol Lazzaro-Weis, Dissertation Supervisor
July 2014


The undersigned, appointed by the Dean of the Graduate School, have examined the dissertation entitled

\section{BRIDGING THE GAP IN FRENCH ROMANTIC REPRESENTATIONS OF BLACKNESS 1750 - 1880: THE MALE MULATTO IN FRENCH LITERATURE}

presented by Huie Tomaz Cunningham, a candidate for the degree Doctor of Philosophy, and hereby certify that, in their opinion, it is worthy of acceptance.

Professor Carol Lazarro-Weis, Dissertation Supervisor

Professor Sheri Harrison

Professor Valerie Kaussen

Professor Mary Jo Muratore

Professor Dan Sipe 
This dissertation is dedicated to the memory of my mother, Ida B. Cunningham. Mom always instilled in her children the value of an education, and she was so pleased to attend the graduation ceremonies for my Bachelor's and Master's Degrees. However, pancreatic cancer took her from us before she could see me earn my doctorate. It is only fitting that the final step in achieving my educational goals be dedicated to her memory, because she wanted this for me long before I even knew that I wanted it for myself. 


\section{ACKNOWLEDGEMENTS}

I would like to acknowledge the skillful, patient and expert guidance of my dissertation committee. I have known each of them as classroom instructors, and their guidance has been invaluable.

Dr. Mary Jo Muratore, who helped me develop a deep appreciation for seventeenthcentury French literature. Baroque aesthetics will always be a large part of my teaching and research interests;

Dr. Valerie Kaussen, who introduced me to the wide, wide world of French Caribbean literature and listened to several ideas for conference papers before I presented them. For years, she routinely prompted me to "move forward" and "join the conversation;"

Dr. Sheri Harrison, who helped me discover the amazing similarities and differences between French and English literature of the Caribbean;

Dr. Dan Sipe, who helped me develop teaching skills in classes other than French grammar;

And of course, my dissertation advisor and mentor Dr. Carol Lazarro-Weis, whose constant encouragement, role-modeling, expert guidance and incredible scholarship have made such a difference in my career path.

I also must acknowledge the several other faculty members, fellow graduate students and friends whose help and support were invaluable along this path: Dr. Flore Zephir, who encouraged me to consider a Ph.D. in Romance Languages when I was still "playing" in Residence Life; Dr. Molly Olsen, who believed I was the right candidate to come to MU; Dr. Mannie Liscum, an amazing professor in every sense of the word; Dr. Traci Sharpley-Whiting, an incredible scholar whose input and encouragement have been invaluable; Dr. Chris Miller, a writer and academic of incredible renown who always responded to e-mails; Dr. Michelle Forbes, a great friend who made me feel so welcome as graduate student; Dr. Etti Naveh-Benjamin, whose passion for social justice is contagious; Pastor Karen Walker-McClure and John McClure, who were unfailing sources of encouragement; Dr. Karen Acton, Dr. Ana Zapata-Calle, Rochelle Baldridge, Marie Line Charles, Wendy McBurney, Kim Marmon and Danielle Neumann.

I also want to acknowledge the incredible faculty at Jackson State University. All of you are wonderful colleagues, and I would like to acknowledge the support, of Dr. Carol Schweitzer, Dr. Sakina Abdur-Rashied, Dr. Jean Chamberlain and Dr. Herd Graves, Dr. Everett Neasman, Dr. Brenda Anderson, Dr. Maria Harvey, Dr. Helen Crump, Dr. Persefanie McDaniels, Dr. Summer Graves and Dr. Kathi Griffin. I also would like to thank Dr. Deborah Barnes and Dr. Lawrence Potter, two leaders in academia who are truly committed to professional development and excellence in education. 


\section{TABLE OF CONTENTS}

ACKNOWLEDGEMENTS $\ldots \ldots \ldots \ldots \ldots \ldots \ldots \ldots \ldots \ldots \ldots \ldots \ldots \ldots \ldots$ Chapter

1. Introduction and Literature Review $\ldots \ldots \ldots \ldots \ldots \ldots \ldots \ldots$

2. Writing the Black Male Body: From La Littérature Négrophile to Romanticism

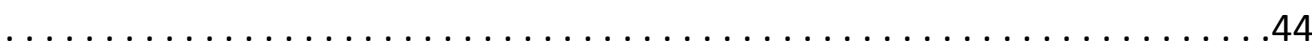

3. Leaving Heterotopia, Interrupting French History: Le Mulâtre Gothique . . 80

4. All In The Family? The Parricidal and Fratricidal Imagery of Le Mulâtre

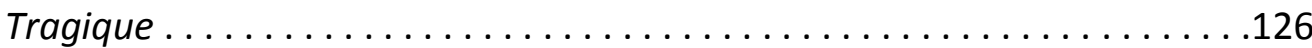

5. Alexandre Dumas and the Three Mulattoes: Le Mulâtre as Romantic Hero ... .......................................... 160

6. Surviving Storms and Defying the Symbolic Order: Interracial Romance . . 206

7. Conclusion: Taming the Anxiety: Le Mulâtre Becomes La Bourgeoisie de Couleur...................................... 240

Bibliography ............................. 255

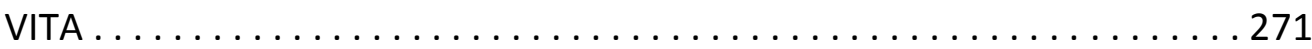


Chapter One: Literature Review of the Male Mulatto in the Enlightenment and Early Romantic Period of French Literature

\section{Introduction}

Eighteenth-century fascination with human diversity and the ethical questions surrounding slavery had unique results on metropolitan French literature. La littérature négrophile was one of the most popular forms of literary expression ${ }^{1}$ in France from the mid-eighteenth century until 1789. Various images of blackness inspired by Antoine LaPlace's 1745 French translation of Aphra Behn's Ooronoko (1688) were employed by both abolitionists and apologists for slavery as they discussed the moral, ethical and economic implications of enslaving other human beings based on the color of their skin. The literary tradition of black images in French metropolitan literature was interrupted by the French Revolution and the chaotic years that followed. Black characters almost completely disappeared from French literature until the Bourbon Restoration, at which time they resurfaced accompanied by another black character absent from la littérature négrophile: le mulâtre. The male mulatto appears much more seldom than other black characters in French Romantic fiction, and is generally portrayed with more psychological depth and a greater need for personal recognition than other male black characters. His disappearance from metropolitan French literature in the midnineteenth century is almost as sudden as his appearance.

The lack of scholarly attention given this literary image in French literature is, in my opinion, as interesting as its sudden appearance and unexplained disappearance. Why was there such a hesitancy to write about le mulâtre, and why has there been such reticence in examining this trope? I suggest that gleaning insights from another literary 
tradition, one less encumbered by the myths of racial egalitarianism as the French literary tradition, might hold some insight to the answers to these questions.

In her insightful article "White Slaves, The Mulatto Hero in Antebellum Fiction," Nancy Bentley brings our attention to a critical imbalance between the trope of the male mulatto hero and the trope of the "tragic" mulatta, both in the frequency of their appearance in American antebellum fiction and the scholarly attention each trope has received. Bentley concludes that there are two major reasons for the lack of scholarship on the male mulatto; first of all, the male mulatto appears much less frequently than the female mulatto in antebellum fiction. Secondly, when the male mulatto does appear, he seems to evoke a greater level of what Bentley refers to as "attendant anxiety" in the text (503). Throughout her article, Bentley gives several reasons for this "anxiety." Specifically, she suggests that the fictional mulatto in American antebellum literature evokes the image of the San Domingo rebellion established in Harriett Beecher Stowe's abolitionist novel and hallmark of western negrophile literature, Uncle Tom's Cabin (1852). More generally, Bentley discusses the possibility that the male mulatto introduces a sociological discussion with which writers of nineteenth century American antebellum fiction had only begun to wrestle: the male mulatto was in some ways a harbinger of the end of white patriarchal culture that pre-supposed a clear racial binary:

... white anxiety came from knowing what the law and society would not recognize: that blood relations bound Africans and Europeans and subverted the idea of a natural boundary between black and white. Repressed in social laws, this knowledge produced in whites a combination of sympathy, revulsion, and fascination for the Mulatto. The person of mixed black and white parentage stood precisely at the place where nature and culture could become unbound (504, emphasis mine). 
Although Bentley is speaking of the literary mulatto in American antebellum fiction, I argue that much of what she observes can be applied to nineteenth-century French literature. The scarcity of the mulatto in American antebellum fiction (and the anxiety which he evokes) could plausibly be explained by the very nature of nineteenth century literature in the United States. Black chattel slavery was an integral part of American history and culture, and societal marginalization was undeniably down the color line. Mulattoes in the United States had no more civil or legal rights than other black individuals, and emancipation only promised freedom, not equal treatment. The culture of the United States did not claim an ideology of equality. This was not the case in France; the ideals of liberté, égalité and fraternité were central to the nineteenthcentury ideology of French republicanism.

In his seminal work on blackness in French literature, Le Nègre Romantique, Personnage Litteraire et Obsession Collective, Léon-Francois Hoffman observes that there are relatively few male ${ }^{2}$ mulatto characters in French literature before 1815 (229). When French Romantic writers chose to portray a male mulatto in their works, they portray him in a variety of unsettling roles: le mulâtre for these writers was a military leader, a wily trickster, a psychopathic villain, a man driven by the need for revenge against white masculinity or an irresistible Don Juan who steals the affections of a woman whom society says that he cannot have. In various ways, the literary representation of le mulâtre seems to be a symbol of societal unrest. Therefore le mulâtre in French romantic fiction, like the literary mulatto in American antebellum fiction, consistently evokes anxiety in the texts in which he appears. It is this sudden 
appearance of le mulâtre on the literary scene and the "anxiety" that this image provokes that is the focus of my dissertation.

Whereas racial discourse was common during the latter half of the eighteenth century, I argue that the images of raced masculinity in la littérature négrophile are actually sentimental tropes of otherness that did not attempt to give any realistic representation of the black population. Taking the position that racial discourse must seek to portray some level of realism, I argue that la littérature négrophile did not contribute to any real progress of racial discourse during the Enlightenment. Le mulâtre makes a definitive break with common eighteenth and nineteenth-century literary images of black masculinity by being endowed with a greater level of personal agency. Certain of these romantic writers find the indeterminacy of race terrifying, and portray le mulâtre as the consummate villain. Others explore the alienation experienced by a mixed-race character in nineteenth century France as another type of romantic separation of the hero from society, and begin to portray race as a social construct that can be redefined or even subverted by a romantic hero who dared claim his personal agency and defy a society that would marginalize him based on his biological race. Therefore le mulâtre in French Romantic fiction can be effectively read as a racial discourse in which blackness entered French history and, eventually, French literary expression. Black characters in the eighteenth century were generally devoid of agency, whereas the character of le mulâtre claims agency.

I will now outline what I hope to be four major contributions of my dissertation to the study of the literary mulatto in French romantic fiction. First, I argue that le mulâtre is a 
transitional trope of incredible importance in the representation of black masculinity in French literature. It is this transition, I will argue throughout this dissertation, which results in the anxiety provoked by this trope. This anxiety is manifested in the images of bastardy, alienation, paternal-filial conflict, psychopathology, exceptional talent and impossible love that characterize romanticism. Secondly, I discuss the tendency to examine the literary trope of le mulâtre during the nineteenth century as a special type or sub-category of le métis, which presents certain challenges in analyzing the literary image of blackness in French literature. I argue that le mulâtre should be read as a different literary image than le métis. Thirdly, I discuss the importance of limiting my dissertation to the literary treatment of the male mulatto to writers in metropolitan France. Lastly, I will examine the sudden disappearance of le mulâtre as a nineteenth century trope after 1848 , a disappearance that I argue is more nuanced and complicated than the decline of Romanticism as an aesthetic. My research is based on historical and literary analysis and critical race theory. I also discuss certain aspects of Freudian psychoanalytical theory (The Family Romance) and theories of identity development introduced by Jacques Lacan. In the next portion of this chapter I will develop each of these four contributions more clearly.

The first contribution that my research will hopefully add to the field of race and Romanticism is the link that I argue should be established between the appearance of le mulâtre as a literary trope of black masculinity and a sudden change in the treatment of black male characters overall in French literature. Although not as common as other forms of blackness, le mulâtre is incredibly important as a transitional representation of 
blackness in French literature. As I mentioned earlier in this chapter, the latter half of the eighteenth century saw the immense popularity of la littérature négophile and variations of two common characters. Argued more thoroughly in the second chapter of my dissertation, I will show how the attribute of personal agency in the black male character allowed Romantic writers to explore the trope of black masculinity, its marginalization and eventual inclusion in French nineteenth century culture and history in more complex ways than la littérature négrophile ever permitted. Therefore le mulâtre redefines the literary treatment of blackness in French literature. This treatment of black masculinity as seen in le mulâtre marks an end of la littérature négrophile and establishes the trope of the black masculine as a primarily Romantic trope, along with the attendant gothic, isolationist, heroic, individualist and rebellious traits so common to Romanticism and that evoke the evasive but undeniable anxiety that is the subject of this dissertation.

The second area of interest for this dissertation is the treatment of le mulâtre as a special type of métissage. Most of the scholarship that studies the literary representation of le mulâtre in French literature (the major works of which are in the literature review portion of this chapter) portrays this tendency to lesser or greater extents. I argue that begin this subsuming of le mulâtre into the larger discussion of métissage is problematic for two reasons. First of all, examining le mulâtre as a type of métissage after the advent of negritude tends to place this vitally important literary trope in the light of a twentieth century literary concept that anticipates the study of $l a$ créolité. This approach tends, in my view, to overlook the fact that race was a very 
critical aspect of French literature in the late eighteenth and nineteenth centuries. Indeed, the manner in which France viewed and portrayed raced individuals is an essential aspect of how France formed national identity during the crucial years between the French Revolution and the colonial expansion into Northern Africa in the middle of the nineteenth century. Therefore to make the "leap" from colonial literature of the Enlightenment and eighteenth century negrophile literature to post-negritude literature of the twentieth century overlooks how post-revolutionary France perceived the racial other, as opposed to the exotic other, in Romantic literature. As a result, this gives an incomplete representation of how France came to perceive black masculinity during the height of its colonial history.

Secondly, examination of le mulâtre as a type of métissage tends to reduce the anxiety evoked by the black / white primal scene of conception into the much broader and much less threatening discussion of biological and cultural métissage. Many of the seminal works on métissage noted in the literature review below tend to efface the distinction between biological métissage and cultural métissage. Their descriptions of the mulatto are qualified definitions, or we can say sub-discourses, of a larger discourse of colonial metissage. For example, in Vergès' work Monsters and Revolutionaries, she states: "Métis troubled the European imaginary because they were the signifier of forbidden desire, of the attraction of the white for the black formulated only as perverted libertinage, and they were, of course, the living testimony of the rape of black women by their masters." (30). As we can see, Verges qualifies her statement of why the métis is so troublesome for the European imaginary and it is in her qualification 
("black women" and "masters") that she implies le mulâtre. Roger Toumson follows a similar pattern in his work Mythologies du métissiage:

C'est au sien d'une structure familiale radicalisée, dans le cadre de la société esclavagiste d'habitation et de plantation que le Métis fait son apparition. Né d'une faute charnelle, sous le signe d'une fatalité généalogique, le Métis est prédestiné à réincarner l'archétype du réprouvé primordial (139, emphasis mine)

By surrounding the term métis with the language of violence and slavery as well as the language of family and biological conception, Toumson makes the term mulâtre clear without stating the term itself. It is almost as if the "attendant anxiety" that Bentley refers to manifests itself in a hesitation to separate the tropes of le métis from le mulâtre in the current scholarship of mixed-race literary studies. This distinction, I argue, is a distinction that must be made, for le métis is as often seen as a site of New World utopic perfection as the transgression of a racial taboo. In his novels Les Natchez, the architect of French romanticism René de Chateaubriand exploits the concept of métissage in the New World to portray images of perfection and underscore the usefulness of French colonialism. As Prasad notes, the métissage that was so idyllic and encouraged between French colonials and Native Americans was greatly discouraged between French colonists and African slaves. In her work Le Métissage dans la littérature des Antilles françaises, Chantal Maignon-Claverie approaches this subject when she compares the le métis, which she qualifies as le métis amerindien, with le mulâtre :

La première figure nous reporte au temps de la conquête et de l'Etablissement, tandis que la seconde est associée à la société de Plantation (ou plus justement d'Habitation). Le substrat idéologique initial ne sera jamais totalement effacé, le métis symbolise la subjugation (la soumission préférée à la mort) de la population indigène ou native ; le 
mulâtre marque un espace de compromis, voire de compromission, dans un univers de violence ( 9 , emphasis mine)

Throughout this dissertation, I make a distinction between the terms métis and mulatto or mulâtre. Whereas the mulatto can be seen as métis in a strictly teleological sense, to subsume the mulatto into a larger category ignores the particular black / white racial discourse that the mulatto presents to France itself. More importantly to the study of blackness in French literature, categorization of le mulâtre as le métis ignores how postrevolutionary Romantic writers struggled to align the reality of a racial hierarchy with the post-revolutionary romantic ideals of liberté, égalité et fraternité. As Vergès outlines, the history of the nineteenth century links race, political rights, and métissage; specifically the male metis, whom she eventually identifies as le mulâtre in a type of historical progression:

The taboo of métissage was based on a series of fantasies and fears: fantasy of sterility of the metis, fear of deviance, fear of transgression of the social colonial order, fear of the degeneration of the white race, of the loss of its purity. Male métis were seen as potential revolutionaries because colonialists feared that they would demand, because of their part of white blood, a specific place in the racial hierarchy of colonialism ... The mulattoes' participation in the French Revolution's political debate made métissage a trope of the politics of race and rights (30, emphasis mine)

The hesitation to name le mulâtre, I suggest, is a hesitation to recognize an important portion of French history that problematized the post-revolutionary ideals of freedom and liberty among all Frenchmen.

This third contribution of my project is an examination of how metropolitan France perceived the mulattoes within France's borders and in French colonies. This vision that France had of mixed-race individuals is, I will argue, inextricably linked to the national perspective of le mulâtre in the history of revolutionary France. The works under 
consideration in this research project are novels and short stories by major and minor writers of both genders, but all of whom are writing for the readership of mainland France. Using critical theory to examine these works will, I believe, give insight on how metropolitan France saw the mulatto population as a traumatic site of memory and the living incarnation of the hypocrisy of the metropolitan ideals of liberté, égalité et fraternité. This was a hidden anxiety that French writers were unwilling to discuss in literature until well into the Bourbon Restoration, when royalist sentiment was fostered and revolutionary ideology called into question.

The fourth and final contribution I hope to make with this project is the exploration of the male mulatto's sudden disappearance from metropolitan French literature after 1848. Argued more thoroughly in the conclusion, I suggest that the disappearance of le mulâtre is more accurately examined as a cultural refashioning of the mulatto as just another raced outsider; in other words, the mulatto simply becomes "black." I argue that this refashioning of le mulâtre can be seen as a waning memory of the mulatto as a symbol of France's failure in Saint-Domingue, a renewed interest and political zeal in the colonization and abrupt political changes in French politics. In short, I argue that the disappearance of the male mulatto is due to several of the same reasons why he was initially excluded from the canon; le mulâtre evoked a certain anxiety that writers were not willing to explore. However, in the interim, the literary mulatto in French literature had given several major and minor Romantic writers the trope necessary to explore the black masculine endowed with agency. 
The sudden appearance of the male mulatto in French literature of the early nineteenth century is quite remarkable. More than one hundred years of French colonial rule and slavery had resulted in a very large mixed-race population (Prasad 45). Due to the massive import of African slaves to the French colonies in the Americas during the eighteenth century, a level of inter-racial blending took place in the French Antilles that surpassed that of the English, Spanish and Portuguese colonies (de Cauna, 21). The presence of the mixed-raced persons in France and her colonies were impossible to ignore, whether slave or free. As Jean-Philippe de Belleau states in his book chapter "Ethnographic Voices in Eighteenth-Century Haiti":

The mulatto was not an unknown category to the Enlightenment. As Jack Forbes has shown, the mulatto became part of the Spanish, Portuguese, and French conceptual vocabulary with the conquest (of America) and re-conquest (of Moorish Spain). The Encyclopédie, the most emblematic work of the Enlightenment, included a short definition of "Le Mulâtre" by Jaucourt in 1765, while in the Suppléments to the Encyclopédie, in 1777, M. de Bellecombe wrote a longer article on the subject with moralistic and racist arguments miscegenation. On the whole, however, the mulatto received minimal attention in France and greater consideration in colonial societies (228, 229 emphasis mine).

De Belleau's claim that the mulatto received minimal attention in France needs to be qualified. The "greater consideration" that the mulatto population attracted in colonial France was, during the sixteenth and seventeenth centuries, uneasy to say the least. Unlike other mixed-race populations in French colonies, mulattoes shared a troubled history with colonial France, which feared that the mulatto population would eventually demand economic and political equality (Kreuger-Enz 391). This anxiety was, to be sure, grounded in substantial socioeconomic reasons. Often wealthy, land-owning sons of metropolitan French aristocrats, male mulattos were groomed for a life of the cultural 
elite in France's colonies if not in France itself. Many mulattoes were sent to France by their fathers for educational opportunities that did not exist in the colonies. They demanded representation in French government assemblies and, despite their cultural and legal status as raced persons, saw themselves as different from the black population and were slave-owners themselves. The French mulatto population became a population apart; there was more wealthy, land-owning mulattoes in French New World colonies than in any other European colonial territory. The rapidly increasing affluent, educated and slave-owning mulatto population elicited a distinctive response from the white lower classes in France's colonies:

The free coloured population ... included a layer of proprietors who in St Domingue between them owned about 100,000 slaves; nowhere else in the Americas did those of partly African descent figure so importantly in the ranks of the propertied classes. The petit blancs and white cultivateurs were prone to resent the success of the coloured proprietor or lawyer, and their rancour was not diminished if the latter, as often happened, bore the distinguished name of a French father ... especially in St Domingue, the free people of colour were still an integral component of the slave-owning class and of the apparatus of slave subjection." (Blackburn 168-69)

Les petits blancs in the colonies, seeing their ambitions of social and economic ascendancy frustrated by the growing mulatto population, resorted to claiming social superiority by the only asset they had at their disposal: race. Mulattoes in the eighteenth century were subjected to a series of legal sanctions which, at various times, forbade them from military service, restricted their choice of marriage partners and denied them the right to representation at l'Assemblé Nationale. This is quite clear when we consider the legal steps taken in the eighteenth century to measure and control the mulatto population in France. As more Frenchmen elected to send bring their slaves with them to France during the eighteenth century, the possibility of a 
growing black / white mixed race population in France became a very real possibility.

This resulted in a series of race-based legislation to track and control the number of enslaved blacks and persons of color in France, who could often obtain freedom through a variety of ways if they managed to stay in France for too lengthy a time. In 1738, royal decrees limited the stay of black slaves in France to three years for the purpose of education. Literary scholar and historian William B. Cohen links the reason for these legislative measures to the anxiety of miscegenation and how it might affect the metropolitan French population:

The French government wanted to limit the stay of slaves because, while they were in France, slaves could be freed without receiving the necessary authorization from the administration in the colonies. Racial fears were actually responsible for the law of 1738. The entry to slaves into France should be discouraged, wrote the king, "for they give the occasion ... of the mixing of black blood in the kingdom." Hoping to prevent such a development, the government introduced specific laws against miscegenation; no slave was allowed to marry in France, even with the permission of his master (Cohen 110, italics mine)

Despite these initial measures, a general unease of the black and mulatto population in France continued, resulting in Louis XV's 1762 decree requiring all black persons (mulattoes included) to register with the French government. This meant that enslaved black individuals in France were required to indicate ownership, and free persons of color were required to divulge their black (and most often, enslaved) lineage. Eventually these measured resulted in the 1778 decree concerning les non-blancs in metropolitan France which permitted the deportation or containment of the black population. It must be noted that legislation forbidding marriage of black persons or requiring registration of the colored population were conditions of civil law unique to France: 
By the royal order of 1778 the slaves in France were all sent back to the colonies or kept apart in stockades. Free men of color were not allowed to enter the country, and those who legally resided in France because they had arrived before the promulgation of the decree were forced to register with the authorities and were forbidden to marry whites. It should be noted that no legal restraints were placed on free men of color or blacks in England, even though they constituted a ten-times-larger proportion of the population. The possible 5,000 blacks in France were part of a nation of 20 million inhabitants, whereas in England blacks represented 20,000 out of 8 million inhabitants. Free blacks in England did suffer from serious discrimination ... But the lack of legal restrictions seems to reveal a less profound level of hostility than was the case in France. Added to the weight of the law in France was social ostracism and prejudice (Cohen 112)

These pieces of legislation indicate that the population of persons with black and white ancestry was a topic of much discussion in eighteenth century French politics and culture. The Enlightenment's discourse of universal man, the ethical aspects of enslaving mankind and the image of le bon sauvage resulted in a popular form of sentimental literature, la littérature négrophile. Introduced into French literature ${ }^{3}$ in 1745 with Antoine LaPlace's translation of Apha Behn's novella Oroonoko, or The Royal Slave, la littérature négrophile presented raced masculinity in what I argue are two basic tropes, l'esclave royal and le bon nègre. Both of these tropes, coming on the heels of what Geoffrey Atkinson calls "The Sentimental Revolution" seemed appropriate to la littérature sensible and were embraced by the literary public during the latter half of the eighteenth century. However, literary treatment of raced masculinity in metropolitan French literature all but completely ignores the male mulatto until well into the Bourbon Restoration, despite the series of legislation that drew public attention to his existence. The metropolitan population of the mulatto was admittedly small, but if significant enough to enact legislation, why not significant enough to inspire literary representation? Opting to use yet another term for race mixing, Francoise Vergès notes 
that little or no attention has been given to the reasons why métissage awakened "anxiety" (9). In the next section of this chapter, I will review the literary and historical scholarly works that deal with this literary image.

\section{Literature Review: Literature}

Whereas there are many studies of the literary representation of le mulâtre in twentieth century French literature, not many focus on the literary representation of the mulâtre in the late eighteenth and early nineteenth centuries. I attempt to begin filling that void with this dissertation. However, there are works that do mention and examine le mulâtre as a part of a larger study on race or the theme of race-mixing in French literature. The first part of my literature review will focus on these works, which are Le Nègre Romantique: Personnage Littéraire et Obsession Collective (1973) by LéonFrançois Hoffman; Le métissage dans la littérature des Antilles françaises (2005) by Chantal Maignon-Claverie; Mythologie du métissage (1998) by Roger Toumson; Colonialism, Race, and the French Romantic Imagination (2009)by Pratima Prasad and Neither White nor Black Yet Both:Thematic Explorations of Interracial Literature (1999) by Werner Sollors. I also include Molly Kruger-Enz's dissertation entitled (In)between Identities: Representations of the Island and the Mulatto in Nineteenth Century French Fiction (2005) and a portion of Chris Bongie's book Islands and Exiles: The Creole Identities of Post/Colonial Literature (1998). Kruger-Enz's project is one of the first dissertations to focus exclusively on the trope of the mulatto in the nineteenth century, and Bongie gives a detailed analysis of Victor Hugo's treatment of the mulatto in BugJargal as a traumatic site de memoire of the Saint Domingue Revolution. 
Le Nègre Romantique, Léon-François Hoffman's seminal work on blackness in French literature from the Middle Ages to the nineteenth century, studies le mulâtre as a trope that captured the Romantic imagination of nineteenth century France due in large part to their perceived role in the Saint-Domingue Revolution. Hoffman notes that there were relatively few male mulattoes in French literature before the era of the Bourbon Restoration, and the mulattoes who did appear in literature after 1815 seemed to share a triple-reprobation: questionable heritage, a possible legacy of slavery, and the general question of inferiority introduced by his or her blackness (229). Hoffman states that many times the literary mulatto is seen as veritable superhuman (235); however, he can be as evil or psychologically twisted as he can be handsome and cultured. The representation of le mulâtre, according to Hoffman, can be read as revelatory of the personal prejudices of the writer who chose to approach le mulâtre as a literary subject:

Pour le raciste, le mulâtre, assimilé au Nègre, suscite une répugnance encore plus profonde que celui-ci. Il est la vivante incarnation du danger suprême : le métissage, la bâtardise, la déchéance de la sauvagerie africaine. Pour l'écrivain qui se veut sans préjugés, le mulâtre est par contre assimilé au Blanc : il s'agit de prouver que la partie noire de son hérédité ne l'empêche pas de se développer intellectuellement, moralement et affectivement dans la même direction que la race des Seigneurs (Hoffman 231)

Hoffman's treatment of le mulâtre, as thorough as it is, comprises only one part of a chapter on nineteenth century literary representations of race and analyzes the trope of le mulâtre alongside the literary representations of le nègre and le blanc. Hoffman cites metropolitan French writers such as Honoré de Balzac, Alexandre Dumas, Alphonse de Lamartine and Victor Hugo and gives detailed analysis on their treatment of this trope. Hoffman's research is central to this project not only because his work is a seminal 
examination of race in French literature, but also because he notices that le mulâtre as a literary trope is "plus complexe que le nègre." (234). Whereas the trope of the black man, or le nègre, does appear in French romantic literature, he is never portrayed with as many levels to his personality as le mulâtre. Hoffman qualifies le mulâtre as black, and studies the literary representation of le mulâtre alongside other representations of blackness:

Je me propose de passer en revue les personnages noirs presents dans la littérature romantique, et d'expliquer pourquoi tant d'écrivains les ont pris pour héros. Par personnages noirs j'entends non seulement les Africains et leurs descendants " pursang ", mais également les Mulâtres ou " sang-mêlés ", ces derniers posant, nous les verrons, des problemes specifiques $(12-13)$

I argue that le mulâtre is characterized by his attempt to resolve a disturbing liminality that affects both his personhood and his status in nineteenth century French society; Hoffman states that it is actually le sang blanc that complicates the circumstance of $l e$ mulâtre, requiring his placement somewhere between the treatment of the white person and the black person (Hoffman 237). I attempt to expand on Hoffman's work by offering a more detailed examination of le mulâtre as a trope that was formed in the French Romantic imagination not only by the events of the Saint-Domingue revolution, but several historical events of the nineteenth century in which France's colonial holdings and the issues of slavery were important considerations.

Chantal Maignon-Claverie's book Le métissage dans la littérature des Antilles françaises : Le complexe d'Ariel gives a thorough examination of the evolution of le mulâtre as the literature of the Antilles progresses from the eighteenth century to the twentieth. According to Maignon-Claverie, the image of le mulâtre during the 
nineteenth century is a creation of white colonial writers who tended to portray le mulâtre as "a romantic and denigrated character" (73). Le mulâtre becomes the ultimate marginalized character, as he is at once white and black, yet neither. The early nineteenth century in France redefined race as it redefined how raced individuals would relate to society based on a racial hierarchy. In such a state of transition, le mulâtre had to play a role. Maignon-Claverie links the evolution of le mulâtre in French literature to the political treatment of les gens de couleur libres as France transforms into a different political world power:

À travers sa politique à l'égard des hommes de couleur libres, la France opère en fait, dès le XVIII siècle, le passage d'une société esclavagiste à une société plus spécifiquement coloniale. L'idéologie raciste, plus qu'une simple survivance de l'esclavage, trouve une fonction nouvelle : justifier la prééminence européenne sur les autres peuples en distinguant artificieusement la liberté civile de l'égalité civique. Le stigmate de la couleur, s'il n'est plus un déni d'humanité, devient le signe de l'infériorité et de la vocation à être dominé (166)

The problem with le mulâtre is that he was not fully black, and therefore problematized the position of the dominated. Le mulâtre was, consequently, the most dangerous potential rebel. At the same time he was not fully white, and as such could not fully be the dominator. Hence, the wealthy, landed and slave owning mulatto occupied a troubling space of liminality both in the literary imagination and French politics. Whereas Maignon-Claverie's study focuses on the representation of le mulâtre in the Antilles, her work is important to this dissertation as it offers an explanation of the difference between the tropes of le mulâtre and le métis. This crucially important distinction, which I will treat more fully in Chapter Two, establishes le mulâtre as a site of violence, conflict and forced submission to white rule. 
Roger Toumson's work Le mythologie du métissage examines the different representations of le métis as a part of how Europe envisioned the New World. Toumson's work is central to the overall study of métissage as he describes how the original concept of le métis, originally a very utopian concept, assumed a more complicated nature and actually became a mythological concept as the idea of métissage became linked to the history of slavery. According to Toumson, the concept of métissage in the light of colonial slavery links the image of the slave master with the image of the father, establishing a type of family romance. Toumson's study is very important to this dissertation due to the careful connections he establishes between the myth of métissage and other literary images, such as those of Oedipus and Cain. These images suggest the inevitability of violence in the image of black / white family romances. As I argue in Chapter Four, this results in the mulatto being the perpetrator of violence within his biological or symbolic family.

Pratima Prasad's work Colonialism, Race and the French Romantic Imagination expands traditional chronological and historical definitions of French Romanticism by claiming that French Romanticism must include the concepts of "French colonial expansion, the antislavery movement, and developments in European racial theory" (9). This book explores how the metropolitan Romantic novel in France both was influenced by France's colonial activity. Prasad examines several different images of race in the nineteenth century, including the black aristocrat (Claire de Duras's Ourika 1823) and the Rebellious Slave (Hugo's Bug-Jargal 1826). Central to this dissertation is her book chapter "The Métis: Plotting Colonial Intimacies: The Miscegenated Subjects of the 
Romantic Novel" which compares the trope of the white / native North American métis with the more controversial white / black métis. Prasad notes that whereas promiscegenation policies encouraged interracial marriage between French colonists and the Native American population, the necessity of racial segregation highly discouraged such relationships between white French colonists and black or African women (46). Examining Bernadin de Saint-Pierre's La Chaumière Indienne, George Sand's Indiana and René de Chateaubriand's Atala, Prasad investigates the rhetorical strategies used to describe mixed-raced characters in the Romantic novel during a time in which scientific racism and belief in polygenism were increasing in French culture. She arrives at the conclusion that "métissage is seen in the Romantic novel as a transgression that cannot be voiced explicitly" (70) but is nonetheless central to the concept of French colonialism. Prasad ends her study of le métis by claiming that métissage allows for a discussion of French "colonial intimacies" which impacted the sexual, affective and domestic relationships of France to her slave-holding colonies (70).

Wernor Sollors's study Neither White Nor Black Yet Both examines several literary representations of mixed-raced individuals, not only in French literature but in American and German literature as well. Sollors emphasizes the role that the mulatto plays in the Romantic era:

The figure of the Mulatto as the ultimate marginal man was of immense importance in nineteenth century Western literature. This character was a living challenge to the central contradiction of the New World, where the anti-aristocratic promise of abandoning hereditary systems in favor of self-made men clashed with slavery and segregation, which reinstated a particularly sharp focus on the question of a character's ancestry (Sollors 241) 
Sollors's study is central to this dissertation project as it examines the role of Le Code Noir in two works that I examine in this dissertation: the short story Le Mulâtre by Victor Séjour and the romantic novella Les Épaves by Mme Charles de Reybaud. In both instances, Sollors notes, the writer creates a story line that seems to assume the reader's familiarity with Le Code Noir. Sollors's examination of these works suggests that, despite the appearances of le mulâtre in French literature, the reading public was so aware of their presence (as well as other images of blackness) that French Romantic writers were able to include the premises of Le Code Noir as a type of inter-textual reference. In this way, I hope to add another level of discussion to the few but growing discussions on race in the eighteenth and nineteenth century. For example, in her article "Who Belongs to Whom? Codes, Property, and Ownership in Madame Charles Reybaud's “Les Épaves,"'”, Molly Krueger Enz reads scholarship provided by Joan Dyan's analysis of Le Code Noir in Dyan's work History, Haiti and the gods, where Dyan states:

The Black Code is a document of limits [. . . We read [. . .] sixty articles that take us into a chilling series of qualifications: prohibitions that permit, limitations that invite excess, and a king's grandiloquence that ensures divestment. There is no time in the Code for discussions of innate inferiority, natural difference, or nightmares of contamination. (203)

Krueger-Enz reads Dyan's statements to conclude that Le Code Noir was "a puzzle that many people did not and still do not realize existed." (Krueger-Enz, Who Belongs to Whom, 230) Using Sollors's work, I argue that quite to the contrary, Le Code Noir (or some adaptation thereof) was such common knowledge among the readership of metropolitan France ${ }^{5}$ that writers such as Victor Séjour, Victor Hugo and Mme Charles de Reybaud could refer to the articles contained therein, assuming their readers could 
follow their inferences. Along with the series of legal steps taken to control the growth of the mixed-race population in France, I argue that the mulatto population was at least as much of a common concern in metropolitan France as in France's colonies. This type of assumed intertextuality with certain French romantic writers, when examined next to the series of legal steps taken to control the growth of the mulatto population in France (discussed above) and the growing acceptance of scientific racism and polygenism during the nineteenth century, I argue makes le mulâtre a literary trope much more common in the French cultural imagination than has been previously studied in depth. In turn, this makes the scarcity of literary representation of this trope more fascinating. Molly Krueger-Enz's dissertation (In)between identities: representations of the island and the Mulatto in nineteenth-century French fiction is one of the first projects that is entirely devoted to the trope of the literary mulatto. Using Hoffman's observations of le mulâtre as a point of departure, Krueger-Enz examines the mulatto as a type of literary metaphor for alienation in the works of Alexandre Dumas (Georges), Victor Hugo (BugJargal), Alphonse Lamartine (Toussaint Louverture), George Sand (Indiana) and Mme Charles de Reybaud (Les Épaves). In these works, Kreuger-Enz explores the "in-between" and exilic traits that "depict the tension surrounding racial (in)equality in France's island colonies (iii). Kreuger-Enz examines the tropes of le mulâtre and la mulâtresse, exploring the tropes of the tragic mulatto and the Revolutionary Heroine in her study of $l a$ mulâtresse. As a whole, (In)between identities examines "how racial and insular identities are representative of larger identity issues in nineteenth century French fiction," (188) and gives excellent analyses of canonical French romantic writers; 
therefore it is an important study for this dissertation project. However, this dissertation doesn't deal with the trope in terms of literary history, i.e. the tropes that precede and follow it. I attempt to expand on this work by placing the literary representation of le mulatre in the historical context of the late eighteenth and early nineteenth century.

In his work Islands and Exiles: The Creole Identities of Post / Colonial Literature, Chris Bongie gives a thorough examination of the mulatto as represented by Victor Hugo in his 1826 novel Bug-Jargal. Although Bongie limits his analysis of the mulatto trope to this one novel, his work is essential to this dissertation project for two reasons. First, Bongie examines the differences between Hugo's first work entitled Bug-Jargal (1824), a story in which the mulatto figure was virtually absent, and the novelized version in which the cruelest and most villainous characters are mulattoes. Whereas the eponymous hero Bug-Jargal (strikingly similar to Aphra Behn's Ooronoko) is handsome, virile, courageous and possessed of great intelligence, mulatto characters in Hugo's novel are ugly, buffoonish, nearly illiterate, villainous and grotesque. ${ }^{6}$ Bongie's study leads him to the conclusion that Hugo "scapegoats," the mulatto by positioning the character as the "place, the topos, where an anxiety about racial (in) differentiation can play itself out." (252). Bongie's study situates Hugo's writing historically; the 1820's was the era of the Bourbon Restoration (an era forced to accept the painful loss of Saint Domingue) and young Hugo at that time was a staunch royalist. Hugo's revision of BugJargal, therefore, can be read as a historical novel that places the loss of Saint Domingue at the feet of a literary image, le mulâtre and connects the image of political and financial loss of le menu peuple to that image. Secondly, Bongie gives a cursory but 
excellent aesthetic analysis of Hugo's concept of the "unpoetic" representation of le mulâtre. Hugo's depiction of the synthesis of opposites incarnated in le mulâtre Bongie's study, therefore helps to establish the trope of le mulâtre in French romanticism as a trope that synthesizes opposites, a trope of liminality and a possible representation of the grotesque. In Chapter Three, I argue that Bongie's observations can be used to examine not only how France remembered the history of Saint-Domingue, but France's anxiety about colonial holdings in the Caribbean during the early years of the Bourbon Restoration.

The paucity of literary scholarship on le mulâtre must be examined in contrast to the very noticeable historical presence of the mulatto population in the late eighteenth and early nineteenth century. Therefore, a thorough historical approach to this topic is required. In the following section of this chapter I will review the historical work that has been done on France's mixed-race population and the role they played in the formation of French colonial and revolutionary history.

\section{Literature Review: History}

The major historical works that deal with the topic of how colonial France dealt with the inevitability of race mixing to which I will refer to throughout my dissertation are There Are No Slaves in France: The Political Culture of Race and Slavery in the Ancien Régime by Sue Peabody (1996); Monsters and Revolutionaries: Colonial Family Romance and Métissage by Francoise Vergès (1999); The French Encounter with Africans : White Response to Blacks 1530 - 1880 by William B. Cohen (2003); A Colony of Citizens: Revolution and Slave Emancipation in the French Caribbean, 1787-1804 by Laurent 
Dubois (2004); The Libertine Colony: Early Creolization in the French Caribbean by Doris Garraway (2005); Claims to Memory: Beyond Slavery and Emancipation in the French Caribbean by Catherine A Reinhardt (2006); Être Noir en France au XVIII Siècle by Erick Noël (2006); Sweet Liberty: The Final Days of Slavery in Martinique by Rebecca Hartkopf Schloss (2009) and The World of the Haitian Revolution, a series of essays edited by David Patrick Geggus and Norman Fiering (2009). I selected these historical works in an effort to gain a comprehensive historical view of how metropolitan France viewed the mixed-race population in all of her colonies, Haiti (Greggus, Fiering and Garraway), Guadeloupe (Dubois and Reinhardt), Martinique (Reinhardt and Schloss) and Réunion (Vergès) as well as in France itself during the eighteenth and early nineteenth centuries. (Noël, Cohen and Peabody).

Sue Peabody's historical work There are No Slaves in France: The Political Culture of Race and Slavery in the Ancien Régime (1996) is a seminal work that challenges the myth of a colorblind France that did not allow slavery within its borders. Focusing on the history of metropolitan France from the mid- seventeenth century until 1789 and supporting her arguments by citing several pieces of race-based legislation since the inception of Le Code Noir, Peabody examines how the presence of black persons in France (both slave and free) affected the French imagination as the threat of miscegenation became a reality. Peabody gives succinct definitions of the racial categories that metropolitan France employed in the eighteenth century, racial categories that were considerably simpler than the racial categorization that existed in France's slave colonies. ${ }^{7}$ Peabody skillfully places her examination of France's treatment 
of the black population both in the colonies and in France within the context of the eighteenth century notions of freedom, which were being complicated by the increased dependence on slavery and the inherent contradictions placed on the slave system by the rapidly increasing presence of free blacks and mulattoes. Peabody states: "French championship of the abstract notion of freedom coupled with the persistent, indeed expanding, reality of slavery in the colonies necessitated a justification whereby the enslavement of some peoples and not others could be explained." (68)

Peabody's arguments are central to this project as she explains that the mulatto population and the duality of their heritage, in an interesting way, gave strength to the abolitionist position. The treatment of mixed-race persons confirmed France's racist ideologies, ideolgies which were in conflict with France's republican cult of liberty. Peabody places the mulatto population and their defiance of categorization near the center of the abolitionist argument:

Mulatto children of planters and their slaves posed an anomaly for the slave system in the colonies. In the bipartite system where black equals slave and white equals free ... the mulatto child [was a] term that belonged to neither category, necessitating some kind of justification for their inclusion in either world. That rationale proved, in the short run, to be racism. It was precisely this dilemma, however, that would also fuel the antislavery movements of the late eighteenth and early nineteenth centuries. (69)

Peabody's astute historical and legal analysis of France's stance on slavery has been seminal to the study of black / white race relations in France; however, I suggest that the situation of the mulatto population in mainland France was much more complicated than Peabody presents. Whereas the abolitionist movement did indeed use the mulatto population as a motive for emancipation, this strategy must be held in tension with the fact that the most economically powerful and influential mulattoes did themselves own 
slaves. During the period Peabody describes above (the late eighteenth and early nineteenth centuries), the mulatto population often distanced themselves from the abolitionist ideologies of organizations such as Les Amis des Noirs. Although deeply patriotic and very supportive of the French republic, the mixed-race population in France and the French colonies deeply resented that their demands for equality were placed on the same level as demands for emancipation. In Chapter Two, I seek to add what I believe to be a necessary depth to this study of the mulatto population by outlining how the mulatto population sought to separate themselves from the black population at large by claiming a filial relationship with metropolitan France. They went to great lengths to assimilate into nineteenth-century French culture. This assimilation resulted in very unique geopolitical relationships with different populations of mulattoes, geopolitical relationships that were, as I argue in Chapter Four, reflected in the metropolitan literature of France.

Françoise Vergès' book Monsters and Revolutionaries: Colonial Family Romance and Metissage (1999) is a thorough examination of interracial mixing in Réunion, one of France's colonies from the end of the seventeenth century until the 1980's. It is Vergès insightful and thorough examination of how métissage (as well as Vergès use of the terms métis and métissage) was seen in France during the eighteenth and nineteenth centuries that concern this project. Historically, Réunion presents an interesting situation for the study of slavery and race-mixing due to the fact that there was no indigenous population for France to conquer in order to claim Reunion. Slaves were bought to Reunion from India, Madagascar, and Africa to meet the need for slave labor 
to harvest sugar, and in 1674 governor Jacob De La Haye wrote the first law prohibiting métissage or race-mixing, stating that this would lead to "degeneration and lack of discipline" (Vergès xiii). However, the inevitable result of métissage, according to Vergès' view, gives an important historical perspective on the relationship between France and the French colonies. Borrowing from Lynn Hunt's work The Family Romance of the French Revolution, Vergès examines the presence of the mixed-race person, whom she often refers to as le métis, as being a traumatic site of memory in the European imaginary. The collective European imaginary found le métis both fascinating and repulsive (Vergès 8). The Enlightenment inheritance of certain myths of the mulatto's biology, coupled with his entrance into History during the latter part of the eighteenth century fed several fantasies of the mixed-race population:

The taboo of métissage was based on a series of fantasies and fears: fantasy of sterility of the metis, fear of deviance, fear of transgression of the social colonial order, fear of the degeneration of the white race, of the loss of its purity. Male métis were seen as potential revolutionaries because colonialists feared that they would demand, because of their part of white blood, a specific place in the racial hierarchy of colonialism ... The mulattoes' participation in the French Revolution's political debate made métissage a trope of the politics of race and rights (Verges 30)

Highly psychoanalytical and therefore quite useful for Freudian readings of mixed-raced figures in Romantic literature, Monsters and Revolutionaries follows Lynn Hunt's historical analysis of the fall of l'ancien régime as being analogous to the death of a paternal figure. Vergès explores France's post-revolutionary role as la Mère-Patrie who is completely devoted to the welfare of her children (the remaining French colonies). This is Vergès's version of what is known as the colonial family romance; an ideal version of how post-Revolutionary France perceived her colonial holdings and dealt as a 
republic with the reality of French slavery. The métis, according to Vergès, is problematic because he makes repression of the horrors of slavery impossible. Afterwards, the image of le métis leaves a pre-Oedipal state of childish loyalty to la Mère-Patrie, becoming thereafter a symbol of an ungrateful child of benevolent Mother France. In this dissertation, I argue that Vergès' analysis of the mulatto male can be used to examine certain spectral, matricidal representations of le mulâtre. I argue in Chapter Three that this rare but important representation of le mulâtre represents France's anxiety over the uneasy relationship with Guadeloupe and Martinique following the Saint-Domingue revolution.

William Cohen's The French Encounter with Africans (2003) is a thorough and broad overview of France's history with Africa, the Atlantic slave trade. Cohen explores in the ways in which France's colonial holdings and slave trade conflicted with the eighteenth century philosophy of universalism, resulting in a series of changing attitudes towards the black population both within metropolitan France and abroad. Beginning his study in the sixteenth century, Cohen traces the development of France's attitude towards persons of African descent, noting the interactions with black people that are unique to France as a major European colonial power.

There are three major reasons William Cohen's work is crucial to this project. First, Cohen's historical analysis of eighteenth century race-based legislation is crucial to a complete representation of the fear of racial mixing in metropolitan France and the myths of métissage surrounding those fears. Second, Cohen takes note of the seldommentioned change among the French liberal intellectual elite towards slavery and the 
plight of the black population in France's colonies after the Saint-Domingue Revolution.

Cohen discusses, for example, the historical context of René de Chateaubriand's statement that is was no longer fashionable to talk about "the noble black" after the Saint-Domingue Revolution. ${ }^{8}$ Whereas this quote is somewhat well-known; but much less known is are the words of feminist and playwright Olympe de Gouge, who after the Saint Domingue revolution stated in the preface of her play L'Esclavage des noirs, "Men were not born for chains, but you prove that they are necessary." ${ }^{9}$ These words, addressed to the black individuals who rebelled, show how the image of black persons among abolitionists began to change after 1791 . Finally, Cohen makes a few remarks about the literary representation of the male mulatto in his book chapter entitled "Scientific Racism." He states, interestingly, that the black male in two literary works, Georges by Alexandre Dumas (1848) and Le Chat Maigre by Anatole France (1879), present miscegenation (in the case of these two books, the love affair between a male mulatto and a white woman) as "being no different from any other relationship between the sexes" (247). However, Cohen qualifies this statement by noting that the racial identification of the authors themselves may contribute to this outcome:

That the principle male in each novel is a mulatto may reveal an underlying notion of closer biological and social affinity between whites and nonwhites of light color. Dumas himself was a man of color. France was very deeply and genuinely an egalitarian; his characters are only very incidentally colored, and color is not an issue in the novel (247, italics mine)

Laurent Dubois' book A Colony of Citizens: Revolution and Slave Emancipation in the French Caribbean, 1787 - 1804 (2004) studies the effect of revolutionary ideology in the French Caribbean, focusing on Guadeloupe. As Dubois notes, the influence of $L a$ 
Déclaration des droits de l'homme et du citoyen declared that French citizens had two basic rights: freedom and private property. This ideology produced several problems in the French Caribbean, where the language and principles of the French Revolution were embraced by both slaves and those who were socially oppressed on account of their race. First, the principle of private property rights placed individuals in French colonies in a position that seemed contradictory: the insurgent slaves' claim to freedom was simultaneously an encroachment on the property rights of France's colonial slaveholders. Secondly, the French republican declaration of freedom removed the one advantage free people of color had: their legal status as being a population separate from the slave population. Third and most important to Dubois' work, it resulted in the free colored population embracing the identity of French republicanism. This had farreaching implications in metropolitan France, which was dedicated to the reestablishment of colonial slavery during the Bourbon Restoration. Dubois' work is essential to this dissertation as he outlines how the establishment of colonial slavery and a racial hierarchy became more problematic as the colored population in Guadeloupe refused to completely return to the pre-revolutionary conception of race, and demanded to be treated, if even to a lesser extent, as French citizens.

Doris Garraway's book The Libertine Colony: Creolization in the Early French Caribbean (2005) is another historical analysis of the cultural formation of the French Caribbean as France ruled her colonies through racial oppression and sexual violence. Garraway looks at the French Caribbean under certain formative elements that shaped French colonial reality, such as the agricultural plantation economy, missionary ideology 
and the system of slavery. Together, these elements of the French Caribbean conspired to create a certain space in the colonial and metropolitan French imaginary; a space of moral deviance. Garraway uses the term libertinage to examine what she argues is "a sexual economy that undergirded exploitative power relations among whites, free people of color, and slaves." (xiii) In this light, Garraway examines the mulatto female as the embodiment of sensuality and the mulatto male as the embodiment of rebellion towards the white plantation owner, who was the symbolic and many times biological father of the mixed raced population of the French Caribbean. Garraway's The Libertine Colony is central to this dissertation for two reasons: first, it discusses how the fascination, guilt and anxiety produced by the mulatto population had certain origins in how the French Caribbean was conceived of as a space of libertinage in the political and literary imagination of metropolitan France. Secondly, Garraway's study of libertinage in the French Caribbean presents a model of the colonial family romance that establishes white paternity over all of the French colonial holdings. This particular model of the colonial family romance has fascinating implications for the mixed-race offspring of a father figure who was at once biological or symbolic father, slaveholder or social oppressor.

Doris Garraway's work gives an important account of the formation of the mixed-race population of the French colonies, and in Chapter Two of this dissertation I attempt to add two essential components of France's mixed-race history to her work. First, I argue that the change in the social standing of the mulatto population must be seen as a shift in paternity from poor engagés to wealthy French colonists. As the French colonies 
grew, so did the number of families that contained bi-racial children of wealthy French colonists. The resentment that Doris Garraway examines on the part of les petits blancs for the mulattoes was not, therefore, simply economic; but rather resulted from an extension of class privilege towards the black offspring of these wealthy colonists. Secondly, I argue that an accurate examination of the mulatto population must take into account their incredible contributions to metropolitan France as a part of the plantation class. The mulatto population did indeed evoke images of libertinage in the French imaginary, but also it also evoked images of political and military agency which were also sources of anxiety in the French imagination.

In Claims to Memory: Beyond Slavery and Emancipation is the French Caribbean (2006), Catherine A Reinhardt traces the evolution of blackness in the French Imagination from the establishment of le Code noir in 1658 to France's celebration of the abolition of slavery in April 1998. Reinhardt's observation of difference between France's celebration of the abolition of slavery and the memory of slavery in France's former colonies serves as the point of departure for her study. Reinhardt examines France's tendency to forget over three hundred years of slavery and celebrate the 1848 abolition of slavery as a testament to France's republican ideals and Enlightenment ideals of universal humanity. Such an approach to France's history, Reinhardt argues, misrepresents the realities of black individuals living in France and French colonies in the eighteenth and nineteenth centuries as well as erases the efforts of slaves to enact their own freedom. Reinhardt's study is particularly important to this dissertation due to her close analysis of the Enlightenment's ambivalent stance in regards to slavery, her 
observations of the representations of blackness in the literature of the eighteenth century and her detailed study of the political and economic influence of the mulatto population in France, as well as the pressure they experienced to accept the myth of assimilation to white French culture, in the years prior to the Saint-Domingue uprising. The efforts that the mulatto population in France made to embody the ideals of French republicanism, Reinhardt argues, is one of the reasons the Saint-Domingue uprising was so unexpected by white plantation owners (169). I argue that this observation is crucial to the myths of the mulatto population as responsible for the events at Le Cap and the horrors of the slave uprising.

Erick Noël's historical study Être Noir en France au XVIII Siècle (2006) offers a rare and thorough historical overview of how les non-blancs were treated in metropolitan France during the years of the Enlightenment. Noël examines how the treatment of les nonblancs in France was a result of the ambivalent racial positions of French thought during the Enlightenment and France's developing conception of alterity, which was influenced by the myth of le bon sauvage. Noël also examines the measures France took to track and control the meager population of les non-blancs within her borders, such as la police des noirs. The book as a whole examines the realities faced by the black population as whole, regardless of class distinctions. Overall, Noël explores the question that, in spite of the racial discourses of the eighteenth century, the position of the black population might have actually been worse at the end of l'Ancien Régime (11).

Noël's book is essential to both this dissertation and to any study of blackness in French history. I attempt to expand Noël's history by observing the role that the mulatto 
population played in the metropolitan conception of blackness by explaining how the mulatto population in France claimed kinship with white French colonizers during the last decade of the eighteenth century. This introduced, as I argue in Chapter Two, a liminal form of blackness in metropolitan France; a free, economically powerful black population that demanded inclusion into French history due to their contributions as colonial landholders.

Rebecca Hartkopf Schloss's study Sweet Liberty: The Final Days of Slavery in Martinique (2009) examines how Martinique's unique history with France helped shape the concept of race in the metropole. Schloss discusses in detail two major historical events that placed Martinique's mixed-race population in an unusual political and social position. First of all, unlike Saint-Domingue and Guadeloupe, Martinique was under the control of Great Britain during the years of the French Revolution. Therefore, slavery was not abolished by the French Republic. When Martinique went back to France in 1802, French officials were uncertain how eight years of British control had affected the legal and civil standing of les gens de couleur in Martinique. Secondly, the loss of SaintDomingue repositioned Martinique as France's largest and most productive sugarproducing colony. These two events placed the wealthy mulatto population of Martinique in a very unique position; a position they used to increase their standing with metropolitan France and redefine what it meant to be French, and white, in the late Restoration and the early years of the July Monarchy.

Schloss's examination of Martinique's history with France is very important for two reasons. First of all, Schloss' book is one of the few books that examine the political 
influence of mulatto population during the 1830 's. During the July Monarchy, as Schloss notes, Creole influence began to wane in French metropolitan politics. As a result, the myth of blood purity became increasingly important as a way of increasing political standing due to the rise of scientific racism in France. Secondly, as a result of the concern with racial purity, the image of the white female emerged as the emblem of white culture that had to be protected from the possibility of interracial sex. I use Schloss's historical analysis of race relations between France and Martinique to inform my study of the le mulâtre and interracial romance in Chapter Six. Schloss's observations of race relations give historical background necessary to examine Les Épaves, which takes place in Martinique, as well as the other works in this dissertation which examine interracial romance, all of which were published during the July Monarchy.

My literature review of the historical references pertinent to my dissertation concludes with The World of the Haitian Revolution (2009), a series of essays edited by David Patrick Geggus and Norman Fiering. This work examines the complex arrangement of political, economic and historical factors immediately preceding and following the Saint-Domingue Revolution. The tome begins with a description of how the slave trade was a project that resulted in Saint-Domingue becoming France's most valuable overseas possession. A considerable mulatto population came to economic prominence in Saint-Domingue. This work examines the many social changes caused by the mulatto population, including the development of a unique brand of French patriotism that existed among the mulatto population and the tension that existed between les petit blancs and the wealthier mulattoes in Saint-Domingue. The rebellion 
in Saint-Domingue left a world-wide legacy, inspiring revolt in Central and Southern America and the fear of slave insurrection in the United States. ${ }^{10}$ The time of the book notwithstanding, the essays do not limit themselves to the colonial events of the SaintDomingue Revolution. These essays also examine in depth the impact the SaintDomingue Revolution had on metropolitan France. Central to this project is the suppression of France's history with Haiti, carefully outlined by Alyssa Goldstein Sepinwall ${ }^{11}$, who examines the collective forgetfulness that France and the United States have experienced concerning the events that led to the world's first black republic. Not only was the Saint-Domingue revolution the first defeat of France's imperial army, it was the most humiliating, since France was defeated by its former slaves. In 1825, Louis XVI grudgingly acknowledged the sovereignty of Haiti. The SaintDomingue revolution, therefore, called for a re-evaluation of how the Enlightenment had constructed race and questioned the ability of the black race to govern itself. In the center of this re-evaluation stood the figure of le mulâtre, who is remembered in literature as the one responsible for the slave uprising. ${ }^{12}$

In the reminder of this chapter I will outline the chapters of this dissertation, citing how I plan to treat each topic and the theoretical models I have chosen to support the premise of each chapter.

\section{Chapter Summary}

As stated above, I argue that the eighteenth century presented two major representations of black masculinity, l'esclave royale and le bon nègre. The mulâtre in the nineteenth century heralded a major change in how French literature represented 
black masculinity. As I show in Chapter 2, le mulâtre distinguishes himself from the other two representations of black masculinity because of a fuller sense of personal agency. Put another way, le mulâtre in early nineteenth century French literature is a black man, but somewhat different ... he is a white black man. His biracial parentage (always assumed to be the son of a white father and a black or mulatto mother, as the romantic image of a black male and white female usually resulted in violent protest among the French public) inscribes the character of le mulâtre in a place of complete liminality. Chantal Maignon-Claverie describes this state of liminality as a state of hypostasis: "Le mulâtre est hypostasié sous une formulation négative ou affirmative; ni blanc, ni noir, ou blanc et noir (9, emphasis mine)." The characters' development from liminality to definition is enacted by his claim to personal agency. In order to make the arguments of le mulâtre as being invested with a level of personal agency (described by Bentley above as "his manhood"), I will use Ethan Kleinberg's observations of Franz Fanon's reading of Hegel and apply these observations to nineteenth century literary representations of le mulâtre. Unlike the other two tropes of black masculinity in la littérature négrophile, which were never liminal figures because they were representations of racial otherness, le mulâtre resolved liminality by claiming personal agency. Because the mulatto was a "white" black man, he was not sealed into a Hegelian "thingness," he not only wanted to be white; in French colonial legacy his paternity was recognized ${ }^{13}$ and he was white. As a "white" black man, le mulâtre in French literature had a right to struggle with oedipal drama, had a place in the family romance of post-revolutionary French politics, and could understandably suffer racial 
marginalization while at the same time owning slaves himself. As a white black man, le mulâtre in French romantic literature could wrestle with identity crisis, challenge the opinions of others, redefine his identity, become a separate entity from his parents and change history. As a man invested with agency, he had the right to challenge society and therefore could either instigate rebellion or choose to dupe social systems by race passing. Le mulâtre could even dare to choose a white woman as the object of his romantic affections and (unthinkable in the French literature of the eighteenth century and for the black male who was not bi-racial in the nineteenth century), the mulatto could become the object of her romantic affections. However, le mulâtre could never be fully white, he had to somehow deal with his own negritude ${ }^{14}$. As I shall show, the trope of le mulâtre allowed certain writers to conceive a raced man undergoing all of the personality depth and complexity of non-raced men in an era of unprecedented social and political change and unrest. Le mulâtre was the ultimate Romantic trope because he was the ultimate outsider.

In Chapter Two, "The Literary Representation of the Black Male Body," I show how the eighteenth century popularized literary representations of black masculinity with the noble savage myth and, eventually, la littérature négrophile. In this chapter, I will argue that the two principle representations of black masculinity in la littérature négrophile, l'esclave royale and le bon nègre, are best appreciated and studied as tropes of sentimentalism that did not seek to present black men as complex human beings with their own history and culture. Rather, these two tropes were images of propaganda that either supported abolitionism or, paradoxical as it may seem, actually justified France's 
participation in the slave trade. The slave trade was represented in French literature, I argue, by the black male body which had a subtext of helplessness and exchange value. In this chapter I examine the enormous influence of Aphra Behn's Oroonoko, or The Royal Slave (1685) on the representation of the black male body and show how the changes made in the French translation (1745) demonstrate how the black male body had actually become a site of literary discourse. Examining these tropes in the light of la littérature sensible, I will argue, shows that the aim of these writers was the evoking of la sensibilité. The black body of le mulâtre, however, presented subtexts of France's history that were uncomfortable; such as France's history of colonial slavery, the racial hierarchy that was an important part of French culture in the eighteenth and nineteenth centuries, France's the loss of Saint-Domingue and, of course, the reality of interracial relationships that resulted in the large mulatto population in France's colonies.

In Chapter Three, “Leaving Heterotopia, Interrupting French History: Le Mulâtre Gothique" I examine the le mulâtre as a gothic figure. At a time in which the French reading public was fascinated with the fantastic, the macabre and the inexplicable, writers such as Victor Hugo and Honoré de Balzac chose to portray male mulattos as individuals capable of eliciting unspeakable horror by performing acts of incredible cruelty. In Honoré de Balzac's Le Mulâtre (1824) and Victor Hugo's Bug-Jargal (1826), the male mulatto is seen as a twisted, demented and even psychopathic character. These characters owe a certain part of their psychological make-up to the rejection they experience as mixed-race characters and therefore represent a very modern discussion of internalized oppression based on race. I also argue that le mulâtre gothique is unique 
in that he is empowered by his position in a heterotopic space which allows him to reverse racial power structures. In Chapter Four, "All in the Family? The Patricidal and Fratricidal Imagery of Le Mulâtre Tragique," I examine the le mulâtre tragique, borrowing a term from twentieth-century literary critic Sterling Brown. Using Victor Séjour's short story Le Mulâtre (1837) and Victor Hugo's Bug-Jargal (1826) I examine this trope using Freudian theories of Oedipal Drama, the Family Romance and the taboo of fratricide. I make a distinction between le mulâtre romantique (a bi-racial male who realizes some form of agency) and le mulâtre tragique (the bi-racial male whose attempts to realize agency involve attempts to commit parricide and / or fratricide) in order to show that there are different representations of the agency afforded to this trope in French romantic literature. Both tropes are studied in the context of historical fiction, for le mulâtre at his most "romantic" or "tragic," is best represented in some form of historical fiction.

In The Chapter Five, "Alexandre Dumas and The Three Mulattoes: Le Mulâtre as Romantic Hero," I show how in detail the trope of le mulâtre romantique not only distinguishes himself from the other tropes of black masculinity but also signals the end of la littérature négrophile by placing the more common tropes of raced masculinity in terms of romantic, no longer purely sentimental, groupings. Using Alexandre Dumas's historical novel Georges (1843), I show how le mulâtre is represented as the nineteenth century romantic hero with all of his charm, intellect, melancholy, duplicitous nature and wiles. Le mulâtre romantique, I will argue, is by far the most modern image of black masculinity in French literature and explores the harmful psychological effects of racism, 
internalized oppression and the process of race passing on an individual and a family unit.

In Chapter Six, titled "Surviving the Storm: Le Mulâtre and Interracial Romance," I examine the le mulâtre as the first black male in French Romantic literature who dares to love and be loved across the color line. This links my examination of le mulâtre with gender studies as well as critical racial theory, for le mulâtre who loves a white woman is both a racial and gender emancipator. By loving a white woman he defies racial norms; by becoming the object of her affections he offers the white woman the opportunity to reject an oppressive patriarchal system. The interracial romance between the male mulatto and the white woman therefore announces possible equality between races and sexes.

I argue that the writers who approach this theme employ a common metaphor, the storm, to represent romantic relationships that were seen as contrary to nature. In this chapter I examine Mme Charles de Reybaud's novella Les Epaves (1838) and return again to Dumas's novel Georges (1843) to examine the eponymous hero's quest to win the heart and hand of the white heroine in spite of society's resistance to their union. I conclude my study of le mulâtre with a search for the reasons for his redefinition and eventual disappearance from metropolitan French Romantic literature. In the conclusion I argue that le mulâtre becomes subsumed into a general categorization of otherness that coincides with the decline of traditional romanticism, the rise of scientific racism, the fading memory of Saint-Domingue and the colonial ambitions of the Third Republic. When observed in this light, I argue that le mulâtre can be seen as a type of 
transitional trope in racial discourse, a link or a bridge between the Enlightenment discourse on race (the sentimental representations of blackness in la littérature négrophile) and certain twentieth-century representations of blackness in French literature (la bourgeoisie de couleur). The literary representations of le mulâtre afforded Romantic writers a chance to explore race as a social rather than biological construct. Images of le mulâtre in French Romantic literature explored, before negritude or créolité, the various images of blackness endowed with agency.

It is my hope that this work will contribute to the growing body of literature on race in the French imagination, a body of literature that has been increasing since the late twentieth century. 
Chapter Two: The Literary Representation of Black Male Body: How Le Mulâtre Changed the Representation of Black Masculinity in French Romantic Literature

In her article "White Slaves," Nancy Bentley states that the literary mulatto is "the figure who most distinctly locates the internal contradictions of domestic ideology and its subtext of the body" (503, emphasis mine). As I have argued in Chapter One, many of Nancy Bentley's observations can be applied to French Romantic fiction. Victor Hugo, the first major French romanticist to portray le mulâtre as a novelistic character, chose to portray the male mulatto as the ultimate villain in his historical romance Bug-Jargal (1826). As Chris Bongie states in Islands and Exiles: The Creole Identities of Post/Colonial Literature (1998), Hugo's portrayal of le mulâtre was an attempt to "determine the identity of this threateningly indeterminate identity, to give it a name in order the more effectively to suppress it" (232). The presence of le mulâtre in Hugo's novel was terrifying specifically because it was indeterminate; the evil mulatto stands in stark contrast to the black (non-mulatto) embodiment of nobility, compassion and courage, Bug-Jargal. French literature had a long tradition of representing the black male body; a representation that drastically changed with the appearance of le mulâtre. In this chapter I show how the black male ${ }^{15}$ body becomes a site of discourse in French literature starting with le Code noir. The male mulatto changes the discourse of blackness in the nineteenth century, introducing a black male body descending from white heritage. As a result, the body of le mulatre introduces the subtexts of racemixing, slavery, illegitimacy and, most important to the literary representation of le mulâtre, liminality. Moreover, unlike the other objectified representations of black masculinity, le mulâtre will demand recognition of his humanity. Therefore, I argue that 
le mulâtre changes the literary representation of black masculinity since the establishment of codified slavery and serves as a link connecting the sentimentality of $l a$ littérature négrophile to negritude. I end this chapter by showing that, like the literary mulatto that Bentley speaks of, le mulâtre in French literature evokes an anxiety by the indeterminate nature, or the liminality, of his body. The liminal representation of $l e$ mulâtre in French Romantic literature is, I argue, a result of how the mulatto population resisted the limitations of le Code noir and therefore changed the concept of blackness in French colonial history.

\section{Le Code Noir, L'Esclave Royal and Le Bon Nègre}

The image of blackness as more than the product of an artistic imagination became solidified in French consciousness with le Code Noir. During the last half of the seventeenth century, the nature of France's colonies changed from ranching and farming systems to large-scale sugar production. Prior to the era of sugar production, the manual labor required to work the French colonies came from a mixture of African slaves and white indentured servants (les engagés), the latter of whom served in the French colonies for a period of three years. The need for laborers increased as methods for refining sugar improved. At the same time, the amount of les engagés dramatically decreased, possibly due to the knowledge of the miserable existence of the slaves and the indentured serving in France's colonies (Cohen 38). In order to maintain her colonies, France needed a permanent supply of slave labor who could not claim manumission. The establishment of slavery and the document that codified it was le Code noir, the purpose of which was stated in its preambule: "en nos Îsles d'Amérique, 
la discipline de l'Eglise Catholique, Apostolique et Romaine, pour y régler ce qui concerne l'état et la qualité des esclaves dans nos dites isles." In his book France and the American Tropics to 1700: Tropics of Discontent? Philip Boucher observes the following about le Code Noir:

On its surface, the Code noir appears to be a relatively humane set of slave laws, if any such laws can be so dignified. It prevented masters from engaging in excessive and arbitrary behavior toward slaves, mandated work-free Sundays and holy days ... established precise guidelines for feeding and clothing bondsmen ... and tried to protect African women form sexual aggression (286-287)

Despite its stated purpose and philosophical function, le Code noir actually served to facilitate the change of France's system of slavery from indentured service to an official chattel system of slavery with a constant supply of slave labor produced by those already enslaved. According to article 13 of le Code noir, following the Roman principle of partus sequitur ventrum, any child of a slave woman was born into slavery. With the establishment of le Code noir, blackness was permanently associated with slavery and a black slave became a slave for life unless manumitted by his owner.

The justification of enslaving the African for life whereas the white engagé was only enslaved for a period of time is, historians admit, difficult to explain (Cohen 48, Peabody 164). Compounding this problem was the fact that slavery in mainland France had long since been illegal; slaves entering France were often able to gain their freedom based on the purported ideology of France being the land of liberty. The rather contradictory situation in the late seventeenth and eighteenth century, therefore, was that France, though publically disapproving of slavery, established and maintained a royal edict that made chattel slavery legal in her colonies. ${ }^{16}$ 
Le Code noir also completely failed as a legal instrument. Many of the statutes were nearly impossible to enforce, and most scholars agree that there was little attempt to actually do so (Curran 236). In his book Avengers of the New World: The Story of the Haitian Revolution, Laurent Dubois comments on the legal efficacy of le Code noir: "For the next century [after the 1685 edition of the Code noir was issued] slave masters [in Saint Domingue] brazenly, openly, and consistently broke almost every provision of the code ... [T] he Code Noir was always 'judged absurd' and its implementation 'never attempted.'" (30). In The French Encounter with Africans, Cohen states that le Code noir was more of a "legal ideal than social reality" (50) and rarely protected slaves from abuse of any kind. In The Libertine Colony, Doris Garraway notes that even the statutes that supposedly were to ensure the basic survival of the black slaves, such as provisions of food, clothing, and protection of the slave from mutilation or murder, were habitually ignored (244). What is indisputable is that the 1685 edit resulted in the complete victimization of the black slave. In sixty articles, the writers of le Code noir denied slaves such rights as the right to assemble, the right to choose or practice any religion other than the religion of France, the right to defend themselves from physical abuse from their master, and the right to have any economic dependence through individual commerce. Manumission itself did not guarantee the full enjoyment of any of the rights denied to slaves. Cohen notes:

The slave code of 1685, which outwardly had the appearance of promoting racial equality, contained contradictions between egalitarian pretensions and the determination never to forget the slave origin of the freedmen (52) 
The agency removed from the black slave by le Code noir was complete and never truly restored. Even manumission was a complex and ambiguous process; le Code noir contained no official procedure for liberating slaves, and manumissions were usually private ceremonies throughout the late seventeenth and early eighteenth centuries (Dubois 73). The lack of official weight given to early manumissions subjected les gens de couleur libres to several societal indignities based strictly on the color of their skin, a color which associated the person with slavery. In Mythologie du métissage, Roger Toumson observes that the provisions of le Code noir established a "racial line" that could not be crossed:

Aujourd'hui méconnu, oublié, voire refoulé par la mémoire collective, le Code noir demeure au regard de l'historien un texte canonique que régit ce principe intangible: l'esclave est une " chose "... Tout homme de couleur même affranchi (en latin libertinnus), tout esclave noir doit respecter [his former master] d'abord parce qu'il est blanc et partant parce que " Maitre " La barre raciale est infranchissable. (85, emphasis mine)

I present the argument that le Code noir not only codified slavery within France's colonies, but also made the black male body the place of complete victimization. As a result, the black male body, whether enslaved or free, becomes the place where agency is denied. The black male was reduced to the color of his black skin, which carried the subtexts of slavery, the heritage of slavery, or the possibility of being enslaved. In her book chapter entitled "Le corps noir dans la fiction narrative du XVIIIe siècle: Voltaire, Montesquieu, Behn, de la Place, Castilhon, de Duras," Catherine Gallouët agrees that the effect of le Code noir was not on the institution of slavery as such; rather, le Code noir "acts" upon the black body itself: 
Le texte dont le titre même inscrit la couleur de la peau dans le système juridique français, et dans son économie ... Avec le Code noir, la régulation d'une pratique économique, l'esclavage, est assimilée à la couleur de la peau. L'Africain est défini par le corps où se situe sa fonction. L'esclave est noir ; l'Africain est noir ; l'Africain est esclave. Au cours du XVIIle siècle et jusqu'à Napoléon, le Code noir reçoit plusieurs modifications qui vont toutes dans le même sens : un durcissement de pratiques dont le lieu est le corps noir. (104, emphasis mine)

The eighteenth century witnessed the questioning of nearly every establishment of I'ancien régime, including slavery. The Enlightenment ideals of universal humanity called the practice of slavery into moral question. The Enlightenment as a whole did not deal directly with le Code noir, but the image of blackness did change radically in the course of the eighteenth century. The growing anti-slavery sentiment in eighteenth century France needed to portray more positive images of blackness than had been previously offered by the travel narratives of the early eighteenth century. The first literary convention that was of some assistance in this regard was the image of le bon sauvage, a concept that had been applied to the American Indian since the sixteenth century (Cohen 70). The Enlightenment's fascination with travel and the model of the traveling philosophe afforded the opportunity to apply the model of le bon sauvage to the Polynesian population and the civilizations of the Far East (Le Supplément au Voyage de Bouganville by Denis Diderot, for example). However, as William Cohen states in The French Encounter with Africans, this model was applied only with difficulty to African populations. Whereas African populations were presented as being closer to nature than European cultures, they were not always seen as being a virtuous people. In fact, the image of the black culture was often portrayed as unusually savage:

At times, the African's presumed savagery and barbarity were accentuated, the better to point out that if even such peoples could be generous and hospitable, take care of 
their children and the age, respect authority and share property in common - then Europeans should be still more virtuous (Cohen 71)

Whereas the trope of le bon sauvage did have some rehabilitating effect on the image of blackness in French literature, his image fell short of changing the image that the French public held of blackness. As a result, the black body remained one that, if not fully deserving of slavery, still benefitted from the cultural advancement that came from European rule. It seems that the major contribution of the image of le bon sauvage to the representations of blackness was that it prepared the way for the two other tropes of blackness in the latter half of the Enlightenment, l'esclave royale and le bon nègre. In these two tropes, blackness inscribed on the body will become a crucial aspect of their literary representation.

The middle of the eighteenth century witnessed an increased fervor in the debates surrounding the enslavement of the black populations. As a result, a series of arguments justifying the perpetual enslavement of black individuals came to the fore. The argument of enslavement as work of evangelism (slavery required baptism) began to lose its appeal among the French public, especially among the philosophes who "took particular pleasure in juxtaposing the tenets of Christianity and the horrors of the slave trade" (Curran 177). The more secular arguments to justify slavery once again returned to the site of the black body which, by this time, had taken on mythical proportions. The physical constitution of the African was seen as being better suited to physical labor, being able to endure the heat of France's colonies. The rapidly growing fields of cultural anthropology and anatomy gave rise to what Andrew Curran has termed "body-based negritude." (Curran 9). The body of the black male was mythically constructed as being 
black in all of its parts; for example, the epidermis of the black male was reportedly darker due to a blackish subcutaneous mucous membrane that lay under the skin, the brain matter of the black individual was reportedly much darker, and the blood a darker red, than that of non-black individuals. Even the reproductive system of black men was reported as producing black semen, which was considered to be an "active and violent structure" responsible not only for black skin but all of the traits associated with black skin, among them decreased intellectual capacity, poor memory and arrested social and cultural development (Curran 127). The tradition of categorizing human beings that was developed in the Enlightenment furthered these assumptions and placed persons with black skin into a race-based hierarchy. In his work Systemae naturae (1735), Swedish physician, botanist and zoologist Carl von Linné arranged human beings in what he termed was a natural hierarchy, the black body occupying the lowest order of human. Other Enlightenment scientists and ethnographers such as Georges Léopold Cuvier and David Hume expanded this position, claiming that groups of people with black skin were more savage, less attractive, less intelligent and therefore less able to rule themselves than those having white skin. Slavery, therefore, was justified due to the end result of civilizing the black race that bore the proof of their inferiority in their skin.

The growing anti-slavery position in France responded to this discourse of the black body. In large part, this was accomplished by the literary tradition of la littérature négrophile, a unique manifestation of la littérature sensible. The task undertaken by negrophile writers of the late eighteenth century was to rehabilitate the image of blackness. In his book Anti-Slavery Opinion in France, Edward Seeber defines la 
littérature négrophile as a literature in which the black person rises above "his despised condition and takes on heroic possibilities (53). Writers of eighteenth century negrophile literature did this by employing the larger Enlightenment aesthetic of Ia sensibilité. In her book Sentimental Figures of Empire in Britain and France (2006), Lynn Festa explains one of the essential aspects of French literary construction of the sentimental:

How does French literature create the sentimental? The French deploy an exemplary man who condenses universal processes into a single figure ... devoting great attention to an abstract concept of the human, to the theoretical elaboration of what the human de base might be. ... For the French, the point is to create a threshold that allows the individual to appear by elaborating a more general template of man; sympathy enables the individual to recognize himself by knowing his own likeness in other men (Festa 36 37, emphasis mine)

In his book Sentimental Narrative and the Social Order in France, 1760 - 1820, David

Denby describes another essential aspect of French sentimental literature:

Central to the theme of sentimental literature is the notion of misfortune ... Without misfortune, the whole process of sentimentalisation, dependent as it is upon the existence of a victim, would be compromised, as would the sense of protest or outrage which sentimentalism generates ... Misfortune is seen as setting the victims apart from the rest of society and conferring upon them a superior status (Denby 13, emphasis mine)

Therefore, the reader of la littérature négrophile had to recognize himself within what had become the myth of the enslaved black body. The recognition of "the other" was not a goal of the negrophile literature of the Enlightenment; la littérature négrophile primarily concerned itself with creating an image of blackness that would be accepted as a part of the concept of the universal man. ${ }^{17}$ The image of universal man was European, eurocentric, male and white. The first black image in literature to meet these criteria was the eponymous hero of Aphra Behn's novel Oroonoko, the Royal Slave. 
Antoine LaPlace's 1745 translation of Aphra Behn's Oroonoko, le prince nègre was an immediate success. Oroonoko was one of the nine most read English novels in France in the middle of the eighteenth century, copies of Ms Behn's novel outnumbering new editions of Don Quichotte, Manon Lescault, Zadig and even Mme de La Fayette's La Princesse de Clèves between the dates of 1760 and 1780. (Seeber 59). The tragic story of an enslaved prince and his love Imoinda captured the interest of France and set a new paradigm for representations of blackness. In Ms Behn's original novel, Oroonoko is described as a man of unusual physical beauty and striking intelligence:

He was pretty tall, but of a shape the most exact that can be fancied; the most statuary could not form the figure of a man more admirably turned from head to foot. His face was not of that brown, rusty black which most of that nation are, but a perfect ebony or polished jet. His eyes were the most awful that could be seen, and very piercing; the white of them being like snow, as were his teeth. His nose was rising and Roman instead of African and flat. His mouth, the finest shaped that could be seen, far from those great turned lips which are so natural to the rest of the Negroes. The whole proportion and air of his face was so noble and exactly formed that, bating his colour, there could be nothing in nature more beautiful, agreeable and handsome ... Nor did the perfections of his mind come short of those of his person; for his discourse was admirable upon almost any subject, and whoever heard him speak would have been convinced of their errors that all fine wit is confined to the white men ... (15)

Throughout the text, Behn continues to describe Oroonoko as a person of passion, leadership ability and social grace. However, it does not escape the careful reader that the aesthetic of beauty imputed to Oroonoko's black body is one of Greek antiquity. Although black, Oroonoko does not possess a body that is black in terms of racial phenotype. The only thing black about Oroonoko is his skin; he shares the language, learning, social graces and culture of a European white male. In creating a hero of very dark skin (in fact, darker than his subjects) Aphra Behn makes a radical departure from the traditional depiction of African royalty, who in visual art was often "painted as 
white" (Gallagher 245). In her article "The Folk, the Nobles, and the Novel: The Racial Subtext of Sentimentality," Laura Doyle notes "In short, Oroonoko is great and noble insofar as he is more like a European than an African" (170). The original text marks a significant change in representations of blackness by placing a noble soul and elevated intellect within a black body. Catherine Gallagher observes in her article “Oroonoko's blackness": "Oroonoko emphatically breaks the traditional Western metaphoric links between black skin and moral degeneracy" (235). Oroonoko's character is not only black, he is blacker than the other slaves in the novel. The subtext of his very black, gleaming, polished body seems to evoke a superiority over his fellow countrymen and sets him apart as the one black body who should not have been enslaved.

In order to appreciate the influence Oroonoko had on the literary representation of the black body, Ms Behn's novel must be compared to the changes made by Antoine LaPlace. Compared to Ms Behn's detailed description of Oroonoko's physical perfection and intellect as compared to the white persons in Oroonoko's company, La Place's translation is very reductionist: "Rien, enfin, ne sentoit en lui le Barbar: et il se conduisoit en toute occasion, comme s'il avait été élevé dans quelque Cour de l'Europe (La Place 18). Catherine Gallouët attempts to explain LaPlace's departure from Behn's original text:

Adapter le roman anglais du goût français n'est pas seulement affaire de style mais d'acceptation par une culture qui n'envisage la représentation du Noir que selon un discours entendu (Gallouët 109, emphasis mine)

Gallouët's explanation for the changes Antoine LaPlace supplies in his French translation suggests that the black body did indeed have a specific and accepted discourse by the 
middle of the eighteenth century, a discourse still connected to the notion of black inferiority. The French anti-slavery movement was much weaker than the one in England and therefore the French reading public as a whole was not yet ready for the literary representation of a black male body that was the equal of the white male body.

La Place's translation of Oroonoko did, however, introduce the French reading public to a novel that set a precedent for the representation of black masculinity in French sentimental literature. Many other writers of Enlightenment negrophile literature would follow Ms Behn's example, and do so more boldly than LaPlace. Jean-François de SaintLambert in Ziméo (1769) describes his eponymous black hero in a manner similar to Aphra Behn's original novel : "les statues de l'Apollon et de l'Antinous n'ont pas des traits plus réguliers et de plus belles proportions." In Joseph LaVallee's novel Le négre comme il y a peu de blancs (1789), the enslaved African prince Itanoko is also described in a manner very similar to Behn's description of Oroonoko: "un noir jais ... un œil perçant, une bouche large et richement meublée" (La Vallée, vol II 27). The hero of Madame de Stael's Mirza (1795) is described in similar manner : "la taille de l'Apollon du Belvédère n'est pas plus parfaite," and "ses traits n'avaient aucun des défauts des hommes de sa couleur."

Althought the representation of the black body began to change with the trope of l'esclave royale, the image remained devoid of personal agency. Blackness may no longer have been as physically repugnant as before, but it still remained a symbol of slavery and exchange value. The black individual may have been attractive, but he was still more of a commodity than a person. The lasting effects of le Code noir still, well into 
the latter half of the Enlightenment, managed to place the black body outside of the realm of individual personhood. Catherine Gallagher observes this in her article:

'Black' . . . is connected to bodies but is also an abstraction from them signifying exchangeable value. It is not so much descriptive of the skin as of the difference between African skin and all other skin that has arbitrarily come to take on the meaning of exchange value per se. (Gallagher 170, emphasis mine)

L'esclave royale as a sentimental figure portrayed a person of noble birth and unusual beauty not as a black person, but rather as an exotic, exceptional individual connected to blackness. His black body places him in the position a slave or, because of his black skin, potentially a slave only able to produce enslaved offspring. Therefore, the black male is cast into "thingness;" he is not a human being rather but a commodity to be bought and sold. The European reader of la littérature négrophile does not recognize black masculinity as "the other" worthy of European recognition, but rather recognizes himself as he might be with black skin.

The other trope common to negrophile literature was le bon nègre, the good or noble negro. This representation of the black masculine took the form of the exceptional slave who was devoted to his master, even going so far as to acknowledge the benefit of his own enslavement. The "Janus-faced" image of le bon nègre in negrophile literature ${ }^{18}$ owes much to the writings of eighteenth century apologists for slavery, such as PierreFrancois de Charlevoix and Jean-Baptiste Labat. In his multi-volume work Histoire de I'isle Espangnole ou de Saint-Domingue, the Jesuit priest Charlevoix presented in the years between 1730 - 1734 the idea that black Caribbean slave was "happy" because he was actually made, or born, for a life of servitude : 
Effectivement, outré qu'un nègre fait autant de besogne, que six Indiens, il s'accoûtume bien plus tôt à l'esclavage, pour lequel il parait né, ne se chagrine pas si aisément, se contente de peu de choses pour vivre, et ne laisse pas, en se nourrissant mal, d'être fort et robuste. II a bien naturellement un peu de fierté, mais il ne faut pour le dompter, que lui en montrer encore d'avantage, et lui faire sentir à coups de fouet qu'il a des Maîtres. Ce qu'il y a d'étonnant, c'est que le châtiment, quoique pousse quelquefois jusqu'à la cruauté, ne lui fait rien perdre de son embonpoint, et qu'il en conserve assez peu de ressentiment pour l'ordinaire (Charlevoix, Histoire de l'Isle Espagnole, 1 :288 emphasis mine)

Charlevoix's ideas reflected a substantial philosophy of the eighteenth century that rationalized slavery by arguing that the black individual was born to serve. Charlevoix seconded the observations of the Dominican priest Labat, who had become one of the leading authorities on the treatment of slaves with his best-selling Nouveau voyage aux isles de l'Amérique (1722) and his subsequent publication, Nouvelle relation de l'Afrique occidentale (1728). In both of these works Labat portrayed black slaves as children who needed the paternal influence of European culture. Labat was often very harsh, even cruel with his slaves and did not hide that fact in his writings. However, his observations of the slaves' gratitude when shown kindness was of great interest to his readers. This aspect of Labat's writing was very comforting to those in mainland France who were removed from, yet concerned with, the realities of France's slave-based economy and the need for control in a plantation environment:

Despite the text's presentation of the undeniable brutality of the slave system, Labat ultimately provided a comforting early eighteenth-century view of slavery that combined an impassive assessment of the day to day economic realities of the plantation system with anecdotal examples of the potentially humane psychology of the slave owner. (Curran 61)

According to Labat, the successful slave master would often secure the undying devotion of his slaves if he treated his slaves in accordance with their child-like mindset. 
Beatings are warranted, according to Labat; but these corporal punishments must be accompanied by the paternal care of a benevolent master:

Pour peu qu'on leur fasse du bien, et qu'on le fasse de bonne grâce, ils aiment infiniment leur maitre, et ne reconnaissent aucun péril quand il s'agit de lui sauver la vie, aux dépend même de la leur (Labat Nouveau Voyage, 229)

The conceptions of the black slave offered by Charlevoix and Labat create the image of the black male body as a child who inhabits the body of an adult. As noted in Charlevoix's quote, the black slave is seen as being naturally strong and robust despite living on little nourishment. More pertinent to the construction of the representation of the black body, Charlevoix states that a black slave easily forgets violence inflicted on his body and seems to demonstrate no need for personal dignity. The black male body, therefore, is not only a place of denied agency, but a place where violence could be inflicted to benefit the slave.

The ideas of Pierre-François Charlesvoix and Jean-Baptiste Labat and the ambivalent status of several philosophes on the idea of racial equality resulted in the image of le bon nègre as a popular literary trope. Le bon nègre was the black male who knew his place in the racial hierarchy and lived in stoic acceptance of his servile position. Possibly the best known example of this image is found in Jacques-Henri Bernadin de SaintPierre's famous pastoral classic Paul et Virginie (1787). The families in Paul et Virginie are separated from French society and served by two loyal slaves, Marie and Domingue. When the young eponymous heroes are lost, the aging yet faithful Domingue searches for and rescues them. The utopian society envisioned by Saint-Pierre doesn't portray slavery as reprehensible in and of itself; only the abuse of slaves by their owners is seen 
as despicable. This use of le bon nègre trope allows white European culture to shape deserving blacks into their image by correcting their stagnant development. Le bon nègre, if able to sufficiently appreciate the superiority of European culture, may be set free to rule over other black people in Europe's place. The body of le bon nègre, then, becomes yet another site of victimization; it becomes a place where one cultural identity is exchanged for another, either by physical force (Charlevoix), benevolence (Labat), or cultural violence. In her article "Le mythe du bon nègre ou l'idéologie coloniale dans la production romanesque du XVIII siècle," Leila Sebbar-Pignon notes that the myth of le bon nègre in eighteenth century literature is a means of transmission of European culture and transforming black identity through the agency of le bon maître: Le bon maître remplit une fonction bien déterminée . . . attentif et sensible, [il] reconnaît à des signes divers les qualités sociales inattendues et les dons exceptionnels des nouveaux esclaves. Ainsi peut-il choisir, sans la crainte d'être trompé, l'esclave qui mérite d'être sauvé, digne de recevoir les éléments essentiels de la culture européenne, puis avec la liberté, une identité nouvelle fabriquée par le maitre blanc. (2588)

Once again, the black body of le bon nègre becomes devoid of any personal agency in order to become a container for the transmission of European culture. Even more subtly, le bon nègre often becomes an apology for black slavery. The enslaved black (le bon nègre) is an exceptional person who loves his master, exchanges the culture and history of his master for his own, and realizes that slavery is ultimately for the good of the black person. The black slave who does not love is master is simply not among the "elite;" to use Catherine Gallagher's reading of Aphra Behn's symbolism, the he would not be a black slave of "gleaming ebony skin," but rather one of the common group of black slaves. 
The two preceding tropes of la littérature négrophile present certain representations of the black male body connected to the themes of helplessness and exchange value. This exchange may be a type of financial transaction, as represented by the slave trade, or the substitution of one culture by another, as represented by the Sebbar-Pignon's concept of le bon nègre. As figures of sentimentality, they were by necessity devoid of any type of agency and defined by their inability to determine their own fate. The writers of la littérature négrophile did seek to humanize and demystify the figure of the black person but only by a method of sentimental writing known as "redundant humanization"; the making human of what was already human. ${ }^{19}$ When the black person rebels (as was common in la littérature négrophile) he wants nothing more that the freedom to return to his primitive state of being. In Masks: Blackness, Race and the Imagination, Adam Lively states possible reasons for this, among them the fact that the black male (also referred to in Lively's text below as "the Negro" and "the African") lacks of any history of his own. The black person is an abstraction, not a person; and therefore even his rebellion lacks any deeper significance:

From Ooronoko to 'The Grateful Negro' (1802), the European imaginative literature on slavery and the Negro is strikingly homogeneous. There are differences of emphasis and inflection, but en masse it presents a common idealization of the African. He ... is defined above all by his enslaved condition, his suffering. To the extent that he is thought to have any existence at all anterior to his being a slave, it is as the expression of a philosophically imagined Nature. He has, of course, no independent culture or history. Before slavery there is only the state of nature, a tabula rasa. And in slavery, too, there is no culture, no economics, no shades of collaboration, no daily, covert acts of resistance... The African is always either kneeling or running amok. His gratitude is an expression of the natural benevolence he carries over from his Edenic, pre-slavery existence. But his vengeance, too, is a natural response, the instinctual backlash of a cornered animal. Black rebellion is like a tropical storm breaking over the Caribbean ... (83, emphasis mine) 
In summary, the images of the black male prior to the early nineteenth century did not advance the discourse of blackness past the image of sentimentalisation. At the end of the eighteenth century the sentimental portrayal of blackness in French literature reached an abrupt end. There were several reasons for this. As David Denby demonstrates, the limit of sentimentality itself is revolution (Denby 56). The French Revolution and the ensuing Terror drastically changed eighteenth century literary tradition (of which la littérature négrophile was a significant part) by closing the salons and colleges (Ridge 9). The second reason for the end of la littérature négrophile was the dependence of this literary aesthetic on class divisions. La littérature sensible was greatly shaped by class distinctions that were abruptly redefined by the French Revolution. Sentimentality, the trait necessary to appreciate the literature of the latter half of the Enlightenment, was considered a trait of the educated and an indication of aristocratic social grace. Those who were not members of the aristocracy could associate with those who were by indulging in the discussion of sentimental texts. This type of social ascendency fell out of favor when class distinctions were swept aside by the French Revolution:

Discussions of the way sentimental texts forge community have largely focused on class. The subtle codes of sensibility allow socially aspiring members of the middle ranks to present themselves as genteel, permitting readers to claim authority based on virtue or merit rather than on historically contingent factors like birth, nation or wealth (Festa 16)

The third, final and most significant reason for the end of la littérature négrophile was the Haitian Revolution. Images of black masculinity were no longer harmless figments of the metropolitan French literary imagination: 
Avec l'insurrection des esclaves de Saint-Domingue et la répressions qui s'inscrit de la part des blancs - causes d'inconcevables atrocités de part et de l'autre - le nègre révolté sortit de son existence purement littéraire pour faire son entrée dans l'Histoire, en se dressant, figure colossale et effrayant, en danger réel et concret (Gewecke, Frauke 55)

The abrupt change in the representation of blackness was followed by several years of empirical censure, during which references to the Saint-Domingue revolution were suppressed. In 1826, Victor Hugo revitalized the trope of l'esclave royal in Bug-Jargal. As David O'Connell notes in his article The Black Hero is French Romantic Fiction, Hugo is only one of several romantic writers who chose to portray black heroes in literature during the 1820's and 1830's, among them Prosper Merimée (Tamango, 1829), Alphonse de Lamartine (Toussaint Louverture, 1850) and Eugene Sue (Altar Gull, 1830). The revitalization of the black male image in French literature was contemporaneous with the development of the romantic hero in French literature. However, the portrayal of these black characters fall short of the complex, multi-layered representations of the romantic hero who claims the agency necessary for the search for self-realization and fulfillment. As a result, the image of blackness was, as far as l'esclave royale and le bon nègre, limited to a type of exoticism during the nineteenth century. These two tropes had a place in the literature of the nineteenth century, but displayed no more agency than la littérature négrophile of the Enlightenment. Advancing the racial discourse required a trope of black masculinity that was not limited to the blackness of his skin, in other words, a black man with a white body. Such a trope could be used to explore what might happen if a black male would demand recognition of his humanity. This would 
only come to pass with the literary portrayal of le mulâtre, a portrayal of blackness that became a part of French culture by means of a very unique history.

\section{Le Code Noir, Le Mulâtre and French Republicanism : A Demand for Recognition}

Le mulâtre was much more of an enigma than the other tropes of blackness in the seventeenth century and throughout the Enlightenment. As Larry Woelff notes in The Anthropology of the Enlightenment, the eighteenth century struggled to find a place for the mulatto (211). The enigma of le mulâtre, like le nègre, centered on the blackness of his body, which challenged and sometimes disproved many of the eighteenth century efforts to group human beings into racial taxonomies. Like le nègre, the body of le mulâtre was inscribed into blackness by the auspices of le Code noir and the provision of partus sequitur ventrum. However both mixed-race individuals and their biological families often sought to challenge the ability of le Code noir to limit the social life of the mixed-race population. These practices, as I shall show, would expand until the mulatto population refused to be associated with black slaves.

The image of le mulâtre first enters French colonial and metropolitan discourse as an unexpected and initially embarrassing result of French colonization, a result of the impropriety of French settlers. The word nègre, meaning simply "black male," came to be almost synonymous with slavery and, therefore, a fixed identity. The term mulâtre is much more complicated. The word itself seems to have come from the term mulato, the Spanish term for mule, evoking images of sterility and hybridity. The Encyclopédie of 1765 differentiates the uses of the term mulato in the Spanish and Portuguese colonies from the use of the term mulatre in the French colonies. In the former, the term mulato 
describes a child born of a black man and an Indian woman, or an Indian man and a negresse. The entry for mulâtre, quoted below, associates the existence of mixed-race children with libertinage as well as attests to the growth of their population:

In the French islands, mulatto signifies a child born of a black mother and a white father, or of a black father and a white mother. This latter case is rare, the first very common due to the libertinism of the whites with the negresses (Encyclopédie 1765 vol 10 p. 853 Jaucourt, Louis, chevalier de. "Mulatto." The Encyclopedia of Diderot \& d'Alembert. Collaborative Translation Project, trans by Jennifer Palmer. Ann Arbor: MPublishing, University of Michigan Library, 2004)

The image of le mulâtre was one of offspring that was a product of sexual license and societal disorder. According to colonial legend, the primary reasons for their existence were the lack of white women in France's slave colonies, the primitive and insatiable sexual appetite of the black woman and the lack of propriety on the part of the French settlers. This perception of the mulatto's parentage presented the subtext of rebellion against established order and social deviancy. Could the fruit of such a union ${ }^{20}$ be a productive member of France's colonial enterprise? In his article The Blood of France: Race and Purity of Blood in the French Atlantic World, Guillaume Aubert observes as early as the 1720 's, the mulatto population was seen as a combination of vices from both races:

In 1722 , the superior of the Jacobin missionaries based in Saint-Domingue emphatically denounced the "infortunate commerce of impurity" between white men and black women. The "criminal coupling of men and women of different species," he explained, posed the greatest threat to the colonies, as they produced "a fruit which is one of Nature's monsters," "a third species of men called mulattoes, who are neither whites nor Negroes but retain all that is the worst in the ones and the others." (Aubert 466) 
In The Libertine Colony, Doris Garraway notes that the black and white mixed-race population, even those who were not enslaved, was associated with the loose morals of France's colonies:

In the law and in colonial narratives, free people of color were figures as a congenitally immoral, bastard race that had inherited the moral ills of libertinage and wore the stain of slavery (Garraway 197)

Another reason the Enlightenment struggled to find a place for the mulatto is that the discussion of their existence disproved certain myths of blackness. According to certain Enlightenment thinkers, the black body was black because it came from a certain geographical location and had, to varying degrees, phenotypical traits that many Enlightenment anatomists and ethnographers attributed to climatic conditions. The phenotype of mixed-race offspring, born and raised in these same conditions, disproved this hypothesis. The monogenesis vs. polygenesis debate, which began to take root in the late eighteenth century, was also troubled by the existence of the mulatto:

Si le nègre et le blanc ne pouvaient produire ensemble, si même leur production demeurait inféconde, si le Mulâtre était un vrai mulet, il y aurait alors deux espèces bien distinctes; le nègre serait à l'homme ce que l'âne est au cheval; ou plutôt, si le blanc était homme, le nègre ne serait plus homme, ce serait un animal à part comme le singe, et nous serions en droit de penser que le blanc et le nègre n'auraient point eu une origine commune ; mais cette supposition même est démentie par le fait, et puisque tous les hommes peuvent communiquer et produire ensemble, tous les hommes viennent de la même souche et sont de la même famille (Buffon, Histoire naturelle, vol 4 $388-389$ )

The body of le mulâtre, therefore, displayed the inadequacies and inaccuracies of Enlightenment racial taxonomies.

The most significant difficulty of defining the mulatto, I argue, results from efforts of certain French colonialists to free their mixed-race offspring from the limits of le Code 
Noir. Garraway's observation of the perceptions of the mixed-race population in the colonies brings another important and disturbing aspect of the mulatto population; the association of slavery with bodies that were not fully black by genealogy. Le Code noir not only removed agency from the black male, but it also denied him any role in determining the status of his offspring through the stipulation of partus sequitur ventrum. This provision had unique repercussions if a bi-racial child was born to an enslaved black woman. The enslavement of the black slave population was the enslavement of "the other," but the enslavement of le mulâtre was the enslavement of France's biological children. This was not a particular concern when the mulatto children were mostly assumed to be the children of les engagés, themselves either in servitude or disenfranchised Frenchmen in search of a better life in France's colonies. However, the social standing of mulatto children become more complex as the living conditions on plantations became more tolerable and affluent French colonizers came to live in France's colonies. Many influential plantation owners sought ways to circumvent the partus sequitur ventrum provision of le Code noir, such as registering the births of mulatto children in baptismal records as "white" and encouraging manumission of mulatto children at age twenty or twenty-one. In his book France and the American Tropics to 1700: Tropics of Discontent, Pierre Boucher observes these measures to protect mixed-race children from racial oppression as an admission of paternity on the part of plantation owners (Boucher 289 - 291). Concubinage with black or mulatto women was very common towards the middle of the eighteenth century. The mixedrace children born to these arrangements were often sent to France, educated, and 
then returned to the colonies to administer their fathers' plantations. The mulatto population began to form a third type of caste within France's colonies, les gens de couleur or les gens de couleur libres. By the end of the eighteenth century, this racially intermediate class began to destabilize the French colonial system that was based on a clear racial binary. Les gens de couleur clearly had black ancestry, but claimed the rights and recognition of their white counterparts. This image of mixed-race individuals as les gens de couleur (cultured, educated, economically empowered and included to lesser or greater extents in white families) began to change the image of le mulatre in the French imaginary. Instead of an embarrassing by-product of sexual libertinage or the coercion of black women by the lower class of les engagés, those of mixed-race were indeed productive members of French colonial society. Gradually, the mixed-race offspring was seen as a liminal being, a black person who claimed the same privileges of the white planter class.

The rapid growth of an economically empowered and educated colored population in France's colonies motivated the white planter class to maintain their social standing by the one resource at their disposal: race. Race-based legislation marginalized the mulatto population and formed a very unstable three-tiered colonial system: les blancs, les nègres, and les gens de couleurs. At various times, the mixed-race population were forbidden from practicing certain professions, holding governmental office or receiving commission in the military, carrying firearms and even wearing certain items of clothing. This despite the fact that the growing mulatto population were children of very wealthy plantation owners. Seeing themselves as the economic and cultural equivalent of white 
Frenchmen, les gens de couleur used their considerable economic resources to demand political change in metropolitan France. However, the mulatto population in Paris was quite small, and for most of the eighteenth century were easily ignored.

The population of les gens de couleur came to the attention of metropolitan France in May 1789 with the convening of les états généreux. White plantation owners throughout the Caribbean quickly organized themselves and sent elected representatives to Paris. Les gens de couleur were not allowed to participate in these elections for fear that their growing population would, in the near future, equal or outnumber the wealthier white plantation owners and disrupt the racial hierarchy by power in L'Assemblé nationale. This slight provoked the first of a number of demands by les gens de couleur to equal rights in revolutionary French politics. This was done in a manner heretofore unthinkable: the mulatto population based their rights to equal treatment on a filial relationship with France. No longer content to be seen as a result of colonialism, French mulattoes demanded recognition in political process due to the fact that they were France's children. However, the white planter class successfully frustrated these efforts for years by confusing the demands of les gens de couleur for equal treatment with the abolition of slavery. As slavery was the source of their wealth and economic power, the majority of the wealthy, landed les gens de couleur vehemently opposed abolition and deeply resented the confusing of their political rights with the freedom of slaves. Finally, in an effort to hold off a full scale impending insurrection throughout all of its colonies, the French government extended full equality to people of color throughout the French Caribbean in April 1792. In her work Claims to 
Memory: Beyond Slavery and Emancipation in the French Caribbean, Catherine

Reinhardt observes that the "in-between," liminal standing of the les gens de couleur worked to their advantage:

Positioned between two racial groups of opposite social standing, people of color manipulated the racial ambivalence of their own social group so as to realize their political interests (117)

The mulatto image entered French revolutionary history defined by racial liminality. It is precisely this association with French history that accords le mulâtre more agency than any other image of black masculinity. The black male and the discourse surrounding his body was a result of Le Code noir, the development of eighteenth century philosophy and the popularity of la littérature sensible. The images of the black male as l'esclave royale or le bon nègre therefore, are fixed as a part of France's imaginary colonial past. This fixed position is a result of how the black body has been represented in the French imagination since le Code noir, which removed agency from the black male body:

The black is always already fixed in the realm of a thing. It is encoded in his skin and in the colonized world in which he lives. He is denied access into the historical progression by the gaze of the white Other who arrests any possibility of teleological development by denying the possibility of black Self-Consciousness. The black is "sealed into thingness." Furthermore, once relegated to the position of an object, a "thing in the schema of an Other and more specifically the white Other, the possibility of ontological investigation is denied (Kleinberg 122, emphasis mine)

The Haitian uprising changed the sentimental figure of black helplessness that was so popular in France during the latter half of the Enlightenment; however, agency was immediately removed from the black body with the reestablishment of slavery and le Code noir in 1802. The mulatto, having carved out for himself a history of agency in revolutionary history, inspired another image of blackness. The mixed-race individual 
could revolt by arms, but also by assembly for political activism and economic empowerment; two elements of agency that were expressly denied the black male by le Code noir. The history of les gens de couleur was, at the onset of French revolutionary history, a fight for recognition by the white other. Léon-François Hoffman discusses this aspect of blackness in Le nègre romantique, comparing other images of blackness to le mulâtre:

[Le Noir] n'avait qu'un nombre limité d'emplois: victime résignée, criminel primitive, héroïque insurgé, Bon nègre épanoui. C'est que, dans la réalité comme dans l'imaginaire, le Noir, c'est l'Autre, l'étranger, l'intrus; il lui faut s'adapter au monde blanc, mais de par sa couleur il n'en fera jamais partie; il en subira le devenir sans participer à son élaboration. Devant sa propre negritude il ne peut choisir qu'entre deux attitudes possibles : I'acceptation stoïque et la revendication par la révolte. Le Mulâtre a par contre du sang blanc dans les veines, ce qui complique la situation. (230, emphasis mine)

I argue that Hoffman's observation of the "white blood" that complicates the portrayal of le mulâtre in the French imagination is more accurately discussed as the mulatto being a black man having a white body. Unlike the popular images of the black body of the eighteenth century, discourse surrounding the body of le mulâtre was very scarce. Therefore, the body of le mulâtre entered French literary imagination undefined by any other racial discourse other than the historical ambiguity of their race, an ambiguity which they manipulated to their advantage. Therefore le mulâtre is inscribed into a complete ambiguity that was consistently reflected in French Romantic literature:

Ainsi est tracée la limite que jamais le Métis ne saurait atteindre : si blanc soit-il, d'apparence, celui-ci n'est jamais, dans tous les cas, qu'un " mal-blanchi. " Le terme premier de cette progression arithmétique est le Mulâtre. Produit de l'union d'un Blanc et d'une Négresse, incarnant le premier degré du métissage, il est le Métis archétypal, le Métis des Métis ; son caractère premier est l’ambiguïté. (Toumson 112) 
The situation of the wealthiest mixed-race individuals in French colonial history must be held in proper tension with their marginalization. At various times, mixed-race individuals in Saint-Domingue, Guadeloupe and Martinique were subjected to a series of social humiliations, including segregated pubic facilities and the barring from commissioning in French military forces. This was due to the lingering effects of le Code noir and the suggestion of a history of slavery by the mulatto phenotype. The body of le mulâtre may approach a white phenotype, but blackness was written upon his body in a way that could not be erased:

On reconnait là l'origine de l'une des obsessions de la société coloniale des XVIle et XVIIle siècles: le topos de la ligne infranchissable qui sépare à jamais le mulâtre de I'homme blanc; on considère alors que les stigmates de l'esclavage sont, de manière indélébile, inscrits dans ses gènes. (Maignon-Claverie 35)

Regardless of social marginalization, the mixed-race population continued to be a growing political and economic competitor for the white plantation class. This became a crucial issue after the Saint-Domingue revolution, during which certain gens de couleur grudgingly joined forces with slave insurrectionists due to metropolitan France's hesitancy to extend equal rights. Because of his proven ability to manipulate the tenets of race to his advantage, the mulatto body was the body most to be feared. As Roger Toumson notes, the mulatto was a black male without black skin:

C'est à l'anthropologie romantique et non à l'anthropologie des Lumières qu'est due la nouvelle articulation des deux termes : un Mulâtre est un Nègre qui n'a pas la peau noire. (Toumson 95, emphasis mine)

The image of a black man who does not have black skin is of crucial importance to the discourse of blackness, because the black body is the place where agency has been 
denied throughout the eighteenth century. Again, Nancy Bentley's observations of the male mulatto in American antebellum fiction are useful as she describes the role of raced male bodies in the domestic novel:

The tacit rules of the domestic novel, I will argue, are these: for women's bodies and black bodies the infliction of violence of abuse can be a means by which the individual achieves a transcendent grace or enriched dignity or identity. But for the body of the white male, this law does not hold. Certainly evil white men can be beaten, humiliated, assaulted; this is imaginable within the poetics of the sentimental novel. But the idea that violence to a white man's body is nonsensical or heretical - Put another way, the physical humiliation of a white man is obscene in the domestic novel; the representation can only degrade, never redeem. (502, emphasis mine)

I argue that this observation can be applied to the mulatto in French Romantic literature. As Margaret Waller observes in The Male Malady, Fictions of Impotence in the French Romantic Novel, the romantic mal du siècle is specifically, almost exclusively, a masculine condition (14). Because the black male who is not a mulatto is remains sealed into Hegelian "thingness" by his skin, he cannot embark on the quest for ontological significance that the white male does in the Romantic tradition. Le mulâtre, however, can because of his status as, in Toumson's words, "un Nègre qui n'a pas la peau noire."

\section{Dislocating French Ideology with the Subtext of the Mulatre's body}

The imperial censure following the Saint-Dominque revolution resulted in very few black characters of any sort finding representation until the Bourbon Restoration. Literary representation of le mulâtre, as a result, took place during the birth and development of French romanticism. Certain romantic writers found le mulâtre to be an image that incarnated several romantic themes. Chantal Maignon-Claverie observes that the difficult situation of le mulâtre is a result of their complex position in society: 
La dualité raciale du mulâtre, sa position dans la société, le fait même que sa situation est complexe, constituée d'un ensemble de cas particuliers . . . tout cela est perçu comme une ambivalence foncière. Dès les origines, comme le montrent les récits des premiers chroniqueurs, le stéréotype de la duplicité du mulâtre s'impose avec une série de connotations négatives : illégitimité, bâtardise, indétermination, compromission, individualisme (164)

These negative connotations become some of the most common traits of the romantic male in the nineteenth century. Bastardy becomes a route of rebellion against the father, which in Romanticism is often portrayed as the symbolic order. Roger Toumson observes the unique aspect of rebellion that the mulatto (here referred to as métis) evokes: "Le romantisme a fait du métis la figure canonique d'une double révolte, à la fois métaphysique et historique; révolte contre Dieu et révolte contre le père." (93) The revolt of the son against the father must differ, however, if the son is excluded from the symbolic order by his race. This was the case with the literary representation of le mulâtre who, even if successful in his rebellion, often found himself without nation or home. In this way le mulâtre is different from the other types of romantic masculinity; he will rebel against established order, but will not find a place of order for himself. The goal of le mulâtre, however, is not to establish a new order; it is simply to resolve his liminal identity as he enters into confrontation with white masculinity and demands recognition for his human worth.

The mulatto engenders anxiety because the demand of recognition for his human worth is a demand for the recognition of a black body. In the remainder of this chapter, I present four basic subtexts presented by le mulâtre that, in Bentley's words, "dislocate" certain French ideologies in the history and culture of early nineteenth-century France. 
Le mulâtre demonstrated the hypocrisy of French republicanism and fraternity.

Regardless of France's tumultuous post-revolutionary history, nineteenth-century French identity was greatly dependent on la devise of liberté, égalité, fraternité. The continued marginalization of les gens de couleur libres, regardless of their wealth, education and military service to France, showed that France was still very selective about who would enjoy the benefits of revolutionary ideology and that "racism continued to underlie republican politics long after 1789" (Sepinwall 324). The mulatto population had attempted, at great lengths, to assimilate into French culture, only to find their expectations of equal treatment frustrated. Until the advent of the Third Republic, the blackness of le mulâtre would keep him out of the circle of liberté, égalité, fraternité that nineteenth century France held as fundamental to its national identity. The novelistic character of le mulâtre, then, is developed as he attempts to somehow resolve his racial ambiguity, or his liminality.

The marginalization of the mulatto population made them an ideal subject for the French romantic writers, who reveled in exposing the hypocrisy of the bourgeois culture. The reading public increasingly comprised le menu peuple, those middle class artisans, merchants and professionals who rose to prominence in the early nineteenth century and to whom romantic writers now had to appeal for success. In her work Trauma and Its Representations: The Social Life of Mimesis in Post-Revolutionary France, Deborah Jenson speaks about the popularity of the mulatto after the July Revolution: There was particular interest in the figure of the mulatto during the "bourgeois" monarchy of Louis-Philippe following the July Revolution. During that time there was a sudden increase in artistic expression by the working class. Writers such as Hugo, 
Lamartine, Dumas and Sand took part in the endeavor of helping workers enter the world of literary production. (147)

As a result, le mulâtre became an intriguing, but still very uncomfortable literary image. Scientific racism steadily gained ground during the first half of the nineteenth century in France. Léon-François Hoffman goes so far as to state that the literary treatment of le mulâtre consistently shows the prejudices of the writers who dared explore the topic:

On peut formuler au départ une hypothèse de travail: pour le raciste, le Mulâtre, assimile au Nègre, suscite une répugnance encore plus profonde que celui-ci. Il est la vivante incarnation du danger suprême: le métissage, la bâtardise, la déchéance de la sauvagerie africaine. Pour l'écrivain qui se veut sans préjugés, le Mulâtre est par contre assimilé au Blanc : il s'agit de prouver que la partie noire de son hérédité ne l'empêche pas de se développer, intellectuellement, moralement et affectivement dans la même direction que la race des Seigneurs (231)

Hoffman's intriguing observation is of crucial importance in the study of this trope, as he effectively observes that the romantic writer who chose a mulatto as a protagonist faced the challenge of writing his or her mulatto character into whiteness. Intellectual and moral development, in French romanticism, were not attributes accorded to the black character unless he was of mixed race. This even affected the right of le mulâtre in literature to rebel; the rebellious black was simply, in Robert Lively's words, "running amok." The closer that that the mulatto possessed the phenotype of a white male, as in Alexandre Dumas' novel George and Mme de Reybaud's novella Les Épaves, the more romantic and justifiable his rebellion was:

The male Mulatto possessed a white man's body . . . To be redeemed the male body required either a new, literally displaced identity as an African or the inviolate identity of the white man with the power to wield physical force (Bentley 513)

Le mulâtre was une site de memoire for the first and most humiliating defeat of the French imperial army. The history of the early nineteenth century had inscribed le 
mulâtre as the one responsible for the Saint-Domingue revolution (Daut 6). I suggest that there were two principle reasons for this. By the last decade of the eighteenth century, the term mulâtre had become an all-encompassing (and rather derogatory) term for all free people of color, whether or not they were actually of biracial parentage (Benot 99). The large mixed-race population in France's colonies and the smaller, but usually wealthy mixed-race population in Paris became more and more of an irritant to the white planter class. The term mulâtre, as a result, came to mean any person of color who aspired to greater social standing. The term associated all mixed-race individuals with the "stain" of slavery and therefore being complicit with the loss of Saint Domingue. The second reason for associating the mixed-race population with the SaintDomingue Revolution was the implausibility of a successful slave revolt in the imagination of metropolitan France. Unable to believe that uneducated black slaves devoid of resources and military training were capable of organizing a successful revolt, the French public of the Bourbon Restoration laid the blame for the horrific massacres of the Saint-Domingue revolution at the feet of the mulattoes, who had both financial resources and a record of military service. This was far more myth than fact, as the gens de couleur libres in France's colonies lost as much property as the white plantation owners. However, the long-standing history of political unrest caused by the mulatto population in Paris, coupled with the 1802 the uprising in Guadeloupe and the long revolution in Martinque, made their responsibility for the Haitain revolution easier to believe. This idea found its way into Victor Hugo's historical novel of the Saint-Domingue revolution: 
Ce n'est pas que les esprits même les plus prompts à s'alarmer, s'attendissent sérieusement dès lors à la révolte des esclaves, on méprisait trop cette classe pour la craindre; mais il existait seulement entre les blancs et les mulâtres libres assez de haine pour que ce volcan si longtemps comprimé bouleversât toute la colonie au moment redouté où il se déchirerait (Hugo, Bug-Jargal 44)

The phenotype of le mulâtre evoked anxieties of racial contamination. The trope of le mulâtre started to gain popularity during a period of French history when the French conception of nationalism included the concept of race purity. The image of le mulâtre was painted as a danger to French national purity due to the philosophy of French utopian thinker Henri de Saint-Simon and the writing of Moureau de Saint-Méry. Henri de Saint-Simon considered the lack of industrial progress of the African countries as proof of their inferiority to European nations. In Saint-Mery states that certain mulattos combine the best of both races into mixed race individuals that are strikingly beautiful. Worse, after a certain combination of race mixing, it becomes almost impossible to tell le mulâtre from his white counterpart. This anxiety manifested itself in the literary tropes of the passing mulatto, examined in this dissertation as the trickster.

The idea of racial contamination became of increasing interest in French literature as writers began to explore the ideas of biological determinism. Writers such as Hugo, Balzac and even Dumas make reference to the black and / or mulatto characters in their novels as having inherited a savagery, a deceptive nature or a sensual nature because of their black heritage. This became especially terrifying if a French woman found herself the mother or sister of a mulatto male, and became the major theme in Honoré de Balzac's gothic thriller Le Mulâtre. 
Finally, le mulâtre evoked the anxiety of the weaknesses of France's colonial system.

The nineteenth century was the apex of French colonialism. As France prepared to expand her colonial empire into northern Africa, le mulâtre served as a reminder of the enormous loss of Saint Domingue, the subsequent loss of Louisiana and France's precarious relationship with Martinique and Guadeloupe. Assimilation of the mixed-race population in France and her colonies had only resulted in a large body of wealthy, landed economic competitors with white plantation owners who constantly demanded equal treatment in a society of rising scientific racism. The image of le mulâtre was the embodiment of France's past "mistakes," and therefore brought France's approach to colonial expansion into question.

In Chapters Three through Six of this dissertation, I examine how romantic writers exploit the trope of le mulatre to express each of these anxieties in the first half of the nineteenth century. The mulatto begins a new racial discourse in French literature; the discourse of race as a social construct that can be overturned by rebellion, trickery, or exceptional talent. Le mulâtre begins the discourse of racial oppression resulting in psychological dysfunction, anticipating later works by Aimée Césaire and Franz Fanon. In this way, I argue that le mulâtre anticipates in several ways the tenets of negritude. One of the principle aspects of negritude, the exploration and valorization of African history and culture, would not be available until the early twentieth century. The history of $l e$ mulatre, on the other hand, was the history of France's colonial holdings throughout the previous two centuries. This was an uneasy history, but it was French history nonetheless. In the next chapter, I will examine how France's history with Saint- 
Domingue and the uneasy relationship with her other colonial holdings resulted in the representation of what I call le mulâtre gothique. 


\section{Chapter Three: Leaving Hetertopia, Interrupting French History: Le Mulâtre Gothique}

The Saint-Domingue revolution was a crippling blow to France and changed France's entire approach to colonial slavery. Curiously, the effects of this revolution on nineteenth-century French history have not been fully studied until the late twentieth century. As I discussed in Chapter Two, Napoleonic censure ensured that this humiliating defeat received as little attention as possible. The Bourbon Restoration aimed to promote a royalist culture and discouraged revolutionary ideology. One of the revolutions the writers of this period wanted to suppress was the Saint-Domingue revolt. Not only was this revolution humiliating, it was very costly. Saint-Domingue had been France's most lucrative colony and historically was the French colony where hardworking petit-blancs could make their fortune. The Napoleonic wars had taken an incredible financial toll on France, and the loss of France's most productive sugar colony was impossible to ignore after 1815. Initially, the Bourbon Restoration was committed to the reconquest of Saint-Domingue again and the return of plantations to their former owners; however, after many failed attempts, Louis XVIII was obliged to grudgingly recognize the sovereignty of Haiti in exchange for an enormous indemnity.

The Bourbon Restoration found itself in a difficult situation in regards to SaintDomingue; the only way to recoup some of France's financial loss was to remember several events that were in France's best interests as a nation to forget. The remembrance of Saint-Domingue brought with it a humiliating defeat, several failed attempts to reclaim an important and lucrative part of France's colonial history, the disappointment of several powerful aristocratic families and a bloody slave revolution. 
The French history that the Bourbon dynasty desperately wanted to shape was being "transgressed" by the image of the black rebel slave. To make things worse, smaller scale rebellions had been taking place in Guadeloupe and Martinique since the last decade of the eighteenth century. The figure held responsible for all of this colonial and political unrest was le mulâtre.

The recognition of Haiti's independence in 1825 was very close to the publication of two novels by men destined to join the ranks of France's major romanticists: Honoré de Balzac's Le Mulâtre (1824) and Victor Hugo's Bug- Jargal (1826). In the tradition of British gothic fiction, Balzac and Hugo wrote psychological and historical novels that feature the male mulatto as a psychopathically deranged, blood-thirsty villain whose presence was a threat to the upstanding white French individual, family or nation. In this chapter I examine the mixed-race characters in both of these novels. I call this character le mulâtre gothique. As all of the other literary representations of the mulatto that I study in this dissertation, le mulâtre gothique lays claim to agency in a way that more prevalent tropes of black masculinity do not. However, le mulâtre gothique distinguishes himself from other mixed-race tropes in this study in two important ways: first, the liminality of le mulâtre gothique goes much farther than evoking anxiety, it evokes terror. Le mulâtre gothique is either psychopathic, blood-thirsty and inhumanly cruel (Bug-Jargal) or the deranged product of a text that involves gothic science fiction reminiscent of Shelley's Frankenstein (Le Mulâtre). The target of his cruelty or deranged passion is most often whiteness, specifically French whiteness whether symbolized by the French aristocratic family or members of the French military. The attributes of his 
personality that render le mulâtre capable of such acts are not necessarily the result of past trauma or environment; they seem to emanate from his nature. Second, le mulâtre gothique seems to emanate from and have a dependence upon a heterotopic space. It is in this heterotopic space that le mulâtre is able to reverse racial hierarchy and either enacts vengeance for a wrong suffered, as in the case of Hugo's Bug-Jargal; or serve as the tool of vengeance for black slave, as in Balzac's Le Mulâtre. In the texts under consideration in this chapter, heterotopic spaces are places where racial confrontation takes place in many forms; physical and psychological torture, incest, political debate, pagan religious ritual and scientific investigation. In the two novels that I will examine in this chapter, the representation of le mulâtre as a gothic villain relies heavily on the memory of Saint-Domingue as an idyllic space disrupted by the Saint-Domingue revolution. First, I will outline certain aspects of European gothic literature as a whole that made la littérature gothique a perfect medium to express racial tension in nineteenth century France. Then, I will examine how both Balzac and Hugo used these characteristics to figure le mulâtre as the embodiment of France's racial anxieties during the Bourbon Restoration. In Balzac's Le Mulattre, the mixed-race villain is a threat to the aristocratic family; in Bug-Jargal, the mixed-race villain is a threat to colonial peace. In both novels, the danger posed by le mulâtre gothique is neutralized by another image common to la litterature gothique: le justicier. Le justicier not only confronts the image of le mulâtre gothique, he also removes the threat of continuing racial mixture. 


\section{Le Mulâtre Gothique}

An analysis of le mulâtre as a gothic figure in early French romanticism presents some problems, as nineteenth-century French literature cannot accurately be said to have had a "gothic" period. The gothic genre was much more popular (and remains much better studied) as either belonging to British or German literature. French literature does have two sub-genres that are similar to the British and German gothic: the eighteenth century roman noir, a result of adventure stories and la littérature sentimentale of the Enlightenment, and la littérature frénétique, a style of horror fiction that enjoyed popularity among France's bourgeois reading public during the Bourbon Restoration. ${ }^{21}$ There are some commonalities in theme between le roman noir, le roman frénétique and European gothic fiction; namely, the heightened sense of terror in the novels classified as such. However, neither le roman noir nor le roman frénétique deal with themes of otherness as commonly as British or German gothic fiction, which is characterized by an anxious encounter with "the Other." (Anolik 8). In the next section of this chapter, I will argue that there are four reasons that the image of le mulattre is best analyzed if we analyze certain themes common to British and German gothic literature and compare them to the two French novels under consideration.

First, gothic literature explores the transgression of natural boundaries and reflects the cultural and national anxieties of the people who produce it. The "popular literature" of France in the 1820's rebelled more and more against the neoclassical restraints of the years between 1800 and 1816. In France as in the rest of Europe, the horrible realities of The Terror and bloody wars across Europe had de-sensitized the reading public to 
human atrocities, and only excess in fiction could truly stir their sympathies. France also had to deal with the horrible memories of a humiliating defeat by former slaves, as well as somehow appease and regain the support of former colonial landowners. These political problems took place during a time of rising scientific racism and the advent of Romanticism. Secular worldviews led to a increased discrediting of monogenesis, which was essentially a stance of the Church. Overall, post-revolutionary France had set aside the Enlightenment ideals of universal man and began to embrace the idea of individualism; not just of individual persons, but of individual groups of people with individual traits that held them in common.

Importantly, William Cohen identifies this new racial ideology as an aspect of Romanticism:

The forces of nationalism released by the revolutionary wars stressed the particular at the cost of the universal. So did romanticism. The romantics shunned uniformity and upheld the particular genius and nature of individuals and whole peoples. The romantics believed also that individuals and groups were endowed with innate qualities that determined their destinies (213)

The popular ideals of Henri de Saint-Simon supported the position of different groups of people and helped establish the ideals of white superiority early in the nineteenth century. Citing the military and scientific accomplishments of a nation as indicative of its superiority, Saint-Simon considered Africa to be inferior to Europe and Africans to be inferior to Europeans. Polygenism seemed to present the idea of race-mixing as a type of transgression against nature. The gothic was fascinated with the concept of the transgression of any natural boundary; boundaries between human and animal, male and female, the living and the dead were all transgressed in gothic literature. In his 
book Gothic Images of Race in Nineteenth-Century Britain, Howard Malchow explores the similarity between mixed-race individuals and the creatures that occupy the gothic literary imagination: "Both vampire and half-breed are creatures who transgress boundaries and are caught between two worlds. Both are hidden threats-disguised presences bringing pollution of the blood." (168). In his introduction to The Cambridge Companion to Gothic Fiction, Jerrold Hogle states, "The Gothic has a tendency to blur any cultural distinctions that it adopts as a theme, such as gender, race, class or even species." (11 - 12) As a result, le mulâtre was a perfect image to represent in gothic literature, as the reading public of the Bourbon Restoration was greatly concerned with a preservation of national purity.

Secondly, gothic literature is indicative of social unrest and cultural anxiety. Gothic fiction scholar Kelly Hurley encourages the examination of literary genres in terms of their "cultural instrumentality," that is, the way that a literary genre negotiates problems or expresses significant terms of its readership. In her book chapter titled "British Gothic Fiction 1885 - 1930," Hurley observes the following characteristic of the gothic:

The Gothic is rightly, if partially, understood as a cyclical genre that reemerges in times of cultural stress in order to negotiate anxieties for its readership by working through them in displaced (sometimes supernatural) form (194)

Hurley also states that the gothic expression of literature can actually serve as a sort of historical or sociological index of the culture that produces it:

If the genre serves to manage a culture's disturbances and traumatic changes, its thematic preoccupations will allow us to track social anxieties at one remove, in the register of supernaturalism (197) 
In this chapter I argue that one of these social anxieties that Balzac and Hugo explore is the French negrophobia of the 1820 's. Fear of the black male was a new development of French Romanticism resulting from the black male's proven ability to enact revenge on French colonialists. In his book chapter titled "French and German Gothic, the Beginnings," Terry Hale states, ". . the Gothic is inherently connected to an exploitation of the emptied-out past to symbolize and disguise present concerns, including prejudices." (76)

Thirdly, gothic literature is a reaction to the extreme rationalism of the Enlightenment and an examination of Enlightenment ideals. Gothic scholars Fred Botting and Terry Hale agree that the emergence of the gothic in the nineteenth century was a reaction to the rationalism of the eighteenth century. The gothic therefore is not simply a reaction to the Enlightenment; it is an examination of the Enlightenment's failure to fully grasp the totality of the human experience:

'Gothic' functions as the mirror of eighteenth century mores and values: a reconstruction of the past as the inverted, mirror image of the present, its darkness allows the reason and virtue of the present a brighter reflection (Botting 5)

This observation is of particular interest in examining le mulâtre as a gothic figure because, as we have seen in the preceding chapter, the Enlightenment struggled to classify le mulâtre as a "raced" individual. The social behavior of the black male was observed as that of an enslaved African, either l'esclave royal or le bon nègre. The nobility of l'esclave royal restrains him from engaging in race mixing; the major black figures in the gothic literature under our consideration are le bon nègre and le mulâtre. In both of the novels that I will examine in this chapter, several Enlightenment ideals will 
be examined, such as the presumed sufficiency of science to deal with the contact of different races, the trope of le bon nègre, the theme of abolition and the hypocrisy of les négrophiles, and the impotence and naïveté of l'ancien régime in regards to the possible dangers of different races in contact with each other.

Finally, gothic literature very often constructs heterotopic spaces to provide historical approaches to cultural anxieties. The France of the 1820's found itself in the difficult and contradictory position of being both a colonial power and a post-colonial power. The possibility of history repeating itself in Martinique and Guadeloupe troubled the French nation as a whole, making le mulâtre a perfect scape-goat for the revisions of French history undertaken by the Bourbon monarchy:

Gothic remains ambivalent and heterotopic, reflecting the doubleness of the relationship between present and past. Indeed, Gothic continues to stand as a trope of the history of the present itself, a screen for the consumption and projection of the present onto a past at once distant and close by. The play of distance and proximity, rejection and return, telescopes history, both condensing the past into an object of idealized or negative speculation and unraveling and disarming the gaze of the present with its ambivalent return (Botting 22, emphasis mine)

Another possibility causing cultural anxiety is the social changes that resulted from the recognition of Haitian sovereignty. Heterotopias are places of unrest that result from the process of different social ordering, counter-sites that allow closer and more critical examinations of society. These examinations of society are presented in literature as the marginalized come to positions of power, and the powerful often find themselves at their mercy. In The Badlands of Modernity: Heterotopia and Social Ordering, Kevin Hetherington explains:

Heterotopia are spaces in which an alternative social ordering is performed. These are spaces in which a new way of ordering emerges that stands in contrast to the taken-for- 
granted mundane idea of social order that exists within society ... They are set up to fascinate and to horrify, to try and make use of the limits of our imagination, our desires, and our sense of power / powerlessness (40)

Le mulâtre gothique examines previous ideas of race in heterotopic spaces.

Heterotopias are the ideal space to examine the mulatto as a part of a frightening French history; they are the mysterious result of a discouraged, previously illegal, union. Moreover, heterotopias create a space to examine le mulâtre in regards to eighteenth century concepts of race, which struggled to find a place for the male mulatto. I will start examining these ideas with Honoré de Balzac's Le Mulâtre.

\section{Balzac's Etienne: Le Mulâtre Gothique and The Heterotopia of Deviation}

Honoré Balzac wrote his gothic thriller Le Mulâtre under the pseudonym Aurore

Cloteaux. ${ }^{22}$ Balzac was a stranger neither to gothic literature nor to the use of a pseudonym; in fact, the two seemed to almost go hand in hand in his works. Why he chose a female pseudonym for this particular work could possibly be explained by the perceived target public, which were mostly women. ${ }^{23}$ The entire novel is a horror-story meta-narrated by a woman who, throughout the novel, interrupts the story to express her horror at the events she recounts and explains that her female insight gives her an understanding of the passions motivating the characters.

The novel opens in an idyllic Saint-Domingue, much more peaceful and utopic than France. In the Saint-Domingue of Balzac's novel, courageous and brave French colonizers were regarded as "les notabilitiés des îles" (8). One of the wealthiest planters of the island was Monsieur Merval de Savenage, a very chivalrous man of military distinction: 
Envoyé fort jeune en Europe, il avait honorablement fait deux campagnes à la tête d'une compagnie de dragons que son père lui avait achetée. Devenu amoureux de la fille de son major, vieux gentilhomme aussi noble que pauvre, il était, après milles obstacles, parvenu à l'épouser. (Le Mulâtre 8)

Balzac's clever description of de Savenage's military service in the cavalry as service "à la tête d'une compagnie de dragons" evokes images of a medieval vassal who manages to earn the love of his lord's noble-born daughter. The two young people are married in France. The reference to medieval imagery is common to the gothic, which often uses themes of castles, labyrinths and mythical creatures such as dragons. The above text comes very close to portraying Merval de Savenage as a young man from la noblesse d'epée, deemed worthy by les faits cheavelresques to marry into a noble family.

The union of this chivalrous young man and noble woman produces a beautiful daughter, Stéphanie Merval de Savenage. Unfortunately, Stephanie's mother dies in childbirth. The heartbroken Merval de Savenage takes his daughter and returns to SaintDomingue, where they can forget the pain of their loss. The kindness of de Savenage family result in a large number of grateful and happy slaves, the most worthy of whom are given the honor of being Stéphanie's personal servants: "Ces jeunes esclaves traités aussi doucement que les domestiques les plus favorisés de l'Europe racontaient à leurs parents les bontés dont ils étaient comblés." (11) Among these favored slaves was a young man named Féo, who finds his greatest personal satisfaction in serving his young mistress. Féo's devotion to Stéphanie leads him to risk his life to save hers when Stéphanie accidently falls off of a cliff and into the ocean while on a hunting trip. After swimming Stéphanie to safety, Féo collapses from physical exertion and is treated by Dr Vincent, the Merval's family physician. As a reward for saving his daughter's life, M. 
Merval de Savenage manumits Féo and his family, and gives the loyal ex-slave a small plantation and the opportunity for an education. When Féo's parents choose to travel back to Africa, Féo chooses to remain in Saint-Domingue in order to continue his education and serve the de Savenage family. Féo's new role as a free black man is not described in the text; however, his duties seem to resemble that of a valet. As a result, Féo is established in the text as an image of le bon nègre, the faithful black who serves white individuals and families out of personal choice.

Stéphanie de Savenage, the gothic heroine in the novel, is extremely rich, very beautiful and deeply concerned for Féo's well-being. She demands that Féo's small farm be located next to the Savenage mansion and assumes that Féo will choose to stay with her and her family when he is given the opportunity to return to Africa. In the text, Stéphanie becomes an image of la mère patrie; the kind, powerful and doting maternal figure of France who rewards slaves for their loyalty and devotion. Stéphanie sees Féo as her personal responsibility, and insists that he stay close to her and her father. The fact that Stéphanie does this at the expense of a vague sense of danger is revealed by another literary element quite common in gothic fiction: the gothic dream. The repressed belief in her ability to transform Féo into another race, and the danger of doing so, are revealed in the text:

Pendant son sommeil, Sténie eut un rêve; elle est fée, et à l'aide de sa baguette magique, elle vient de transformer le fidèle, mais noir Féo, en un jeune prince blanc comme un lis, dont elle se plait à protéger l'intéressante jeunesse: bientôt elle le lance dans le monde, lui fait tuer des lions, des serpents et de méchants princes, blancs cependant comme lui; enfin elle est sur le point de lui accorder la plus noble et la plus douce récompense; mais voici qu'au moment même où elle tend à Féo une main qu'elle croit donner au prince le plus amiable et le plus blanc qu'il soit sur le globe, le beau prince disparait, et à sa place se montre un grand vilain génie, noir comme l'ébène qui, 
fixant sur elle une prunelle sanglante, la regarde avec un sourire affreux, et l'entraine dans une grotte profonde; la tout disparait, et la pauvre Sténie, victime d'un supplice qu'elle ne peut concevoir ni définir, n'ose même pas invoquer le secours de dieu, terrifiée qu'elle est par la vue de deux gros yeux noirs, brillants, isolés dans le vide et qui semblent planer sur elle comme l'épée de Damoclès. Le jour vint enfin délivrer Sténie du supplice que lui avait imposé sa riche imagination. Pleine d'une terreur dont elle ne peut se rendre compte, elle se lève, court après de sa gouvernante avec l'intention de chercher un refuge, mais à peine arrivée près d'elle tout est oublié et Sténie ne conserve plus du cauchemar affreux qui l'a fatiguée qu'en malaise général dont elle ne peut assigner la cause. (Le Mulâtre 18)

The above text, I argue, introduces a gothic inversion of the Pygmalion myth into Balzac's text. Seeing herself as capable of transforming Féo into a white vassal in her service, Stéphanie (Sténie) proceeds from protecting her slave to releasing him into the world to battle her enemies which were "as white as he." I suggest that this imagery refers to other nineteenth-century European colonial powers that France (la mère patrie) believed could be conquered with the loyal service of French slaves in Martinique and Guadeloupe. The Pygmalion myth of the gothic tradition (such as in Shelly's Frankenstein, which greatly influenced Balzac's early writing) usually results in the creator being in danger from their creation. This particular type of Pygmalion myth calls for a re-examination of two Enlightenment representations of black masculinity: le bon nègre (which I have previously mentioned) and le nègre philosophe, the exceptional black slave who accepts the superiority of European culture and learning. In Balzac's novel, Féo becomes greatly disturbed by his education. The years immediately following his manumission speed by in a type of innocence during which Féo is blissfully aware of his growing passions for Stéphanie:

Quelques années se passèrent rapidement, et ni M. Merval, ni Sténie, ni aucun commensal de l'habitation, ni Feo lui-même ne vint soupçonner qu'un amour effréné 
brulait le cœur d'un noir pour la noble et riche héritière du plus opulent propriétaire des colonies françaises... (Le Mulâtre 32)

The more Féo absorbs the Eurocentric education that his former masters give him, the more he becomes increasingly convinced of his innate inferiority. Far from empowering him to acquire a level of agency, Féo's education convinces him that he is condemned by nature to be less than the family he has grown to love and chosen to serve:

Féo, élevé dans l'esclavage et avec tous les préjugés de l'esclavage, se regardait toujours malgré la liberté dont il jouissait, comme un être d'une nature imparfaite, condamné par cette même nature à vivre et à mourir dans un cercle extrêmement circonscrit. Ses progrès dans les espèces d'études qu'il avait entreprises ne faisaient qu'ajouter à cette intime conviction, car elle lui permettait d'admirer l'étendue des connaissances de Sténie et les talents vraiment admirables dont cette jeune fille était douée. (Le Mulâtre 33)

Féo's education seems to include an appreciation for European standards of beauty. As his name implies, Féo was not the black Adonis of late eighteenth-century negrophile literature. The black male body, even that of le bon nègre and le nègre philosophe, is read in Balzac's novel as wholly unattractive and therefore seems to mark a distinct change from the representations of la litterature négrophile. Féo falls in love with his mistress, and the very education that enables him to appreciate her gifts and talents convinces him that he is repulsive both to her and to himself:

L'amour même, l'amour qui, dit-on, rapproche les distances, était précisément ce qui les faisait paraitre plus immense aux yeux du jeune nègre. Transporté d'une brulante admiration pour Mademoiselle de Savenage, Féo ne pouvait reporter ses yeux sur luimême sans un profond dégout. Son teint, ses cheveux, ses traits, si différents de ceux qu'il contemplait dans Sténie, avaient anéanti en lui la vanité qui est la mère de l'espérance et par conséquent de l'amour. Son ignorance (car comment oser nommer autrement l'innocence d'un nègre) son ignorance, disons-nous, avait mis des bornes à la violente passion qui le dévorait. Son bon cœur, sa reconnaissance et son respect religieux pour la fille de son bienfaiteur, avaient achevé de déguiser entièrement à ses yeux et aux yeux de tous les commensaux de l'habitation, ses véritables sentiments qui 
ne paraissaient être qu'un dévouement, exalte a la vérité, mais naturel et louable dans ses conséquences (Le Mulâtre 33)

The above text introduces an important aspect of gothic literature: an examination of the excesses of abstract reason credited to the Enlightenment. Both images of le bon nègre and le négre philosophe are tested in Balzac's text, and both are presented as weaknesses of the excess of reason. The admirable devotions of le bon nègre are presented as a possible mask for hidden, much more terrifying motivations. Rather than becoming the grateful container for Eurocentric culture embodied by the image of le nègre philosophe, Féo becomes a confused and dangerous presence in the house of his masters.

Féo's devotion to Stéphanie is again tested and proven when Stéphanie accepts the marriage proposal of a handsome, wealthy and very naïve French nobleman. After le Comte de Clémingis and Stéphanie marry, the family decides to relocate en masse to the Clémingis castle in France. When a hurricane interrupts their naval voyage, Féo once again saves Stéphanie's life as well as the life of her father and husband. The relocation of the Clémingis family to France marks a crucial turning point in the text as the family is moved out of the idyllic and utopic space of Saint-Domingue into the heterotopic space of a medeival French castle. The Clémingis castle helps to establish the site of Feo's continuing education as a heterotopia:

The main features of Gothic fiction, in neoclassical terms, are heterotopias: the wild landscapes, the ruined castles and abbeys, the dark, dark labyrinths, the marvelous, supernatural events, distant times and customs ... (Botting 19)

The very geography of Saint-Domingue, the racial utopia of French colonial society, seemed to place limits on Féo's passions for Stéphanie. In France, these passions are no 
longer policed by as strict a system of racial hierarchy and begin to exceed Féo's control. The Cléminigis castle becomes a certain type of heterotopia: a heterotopia of deviation. In his essay Des Espaces Autres (1967), Michel Foucault defines heterotopias of deviation as alternate sites for individuals whose behavior is deviates from required norms (5). Surrounded by French culture and France's Enlightenment heritage of sensibilité, Féo can no longer deny his passions to possess Stéphanie. Away from the utopian environment of Saint-Domingue, he begins to act on his passions. Féo's continued education in France transforms his noble heart and drives him literally insane. Balzac's narrator lays the responsibility for this transformation from noble servant to menace at the feet of the teachers of French Enlightenment and the vulgarization of knowledge:

Hélas! comment a-t-il pu se faire que ce jeune homme né avec une âme tendre et reconnaissante soit devenu tout à coup un être cruel et malfaisant? Qui a changé le naturel de ce malheureux noir ? Qui l'a rendu barbare et stupide ? c'est la même cause qui a égaré encore tant de jeunes gens faits pour la vertu ; une éducation mal dirigée. Honte à nos prétendus sages, à nos soi-disant instituteurs! (Le Mulâtre 92)

The heterotopia of the Cléminigis castle examines more Enlightenment tropes than le bon nègre and le nègre philosophe. The castle provides an environment in which Balzac examines the "excesses" of Enlightenment reason. Dr Vincent is a type of Voltarian "Plangloss," a portrayal of "irresponsible science." This, too, is a common image of gothic literature that Balzac uses to great effect. Dr Vincent develops a keen interest in Féo and sees to a large portion of his philosophic as well as his scientific education. "Le Docteur Vincent avait eu de tout temps un grand fonds d'amitié pour le jeune noir; le regarder comme son élève et comme son ami." (Le Mulâtre 58) Dr Vincent's keen sense 
of science seems to blind him to the realities of his surroundings. Sensing his grip on reality starting to weaken, Féo seeks counsel from Dr Vincent, who doesn't at all suspect that Féo might be suffering from unrequited love, melancholy, or jealousy. The aspects of human experience that couldn't be explained by science seem to completely escape Dr Vincent. Furthermore, the hapless doctor demonstrates a confidence in Enlightenment ideas of racial difference, such as differences in blood chemistry and temperament:

Pour un autre home que le bon docteur, pour un home enfin plus versé dans la science du monde, que dans la chimie et les mathématiques, la confidence de Féo eut été aussi claire que précise ... Il ordonna donc des bains et des saignées, au lieu de faire entendre la voix de l'espérance, et celle de l'honneur, au lieu surtout de prévenir le comte et $\mathrm{M}$. Merval, du danger qui les menaçait, il ne leur parla que de l'âcreté du sang des hommes d'Afrique, et de la différence qui existait entre leur tempérament et celui des Européens. (Le Mulâtre 59)

Dr Vincent represents what Kelly Hurley refers to as "careless or irresponsible science" that results in monsters such as Mary Shelley's Frankenstein (Hurley 192). His naïve believe in the unfounded assumptions about racial differences that characterized the Enlightenment would eventually leave the Clémingis family in grave danger.

Féo's insanity sends him from the Clémingis castle for long periods of time during which he roams the French countryside. Convinced that Stéphanie is deliberately ignoring his love for her, Féo plans to take revenge. Using his education and keen aptitude for science, Féo concocts an anesthetic ${ }^{24}$ that he injects into a large basketful of wild mountain strawberries. He delivers the fruit to the Clémingis chateaux, placing all of the inhabitants of the castle into a drug-induced sleep. That night, Féo enters the 
castle and climbs to Stéphanie's room. Under the influence of Feo's concoction,

Stéphanie sleeps deeply and dreams of her husband:

La jeune comtesse dormait profondement, doucement agitee par un reve de bonheur, sa bouche souriait avec une grace enchanteresse. Est-ce toi, mon ami? s'écrie-t-elle. Le noir laisse échapper un ricanement sourd, s'élance vers la porte, la verrouille, et revient à pas de loup auprès du lit de sa victime (Le Mulâtre 100)

Féo's ensuing contemplation of his former mistress displays a complete lack of pity or sense of human decency. He announces his rape of Stephanie with a cry that displays his true intent, which is to defile an angel and destroy her beauty:

Là, il s'arrête un moment, non que le respect et la pitié lui parlent encore, non que la vertu jette un dernier cri dans son coeur, mais il veut contempler sa victim, il admire avec un orgueil satanique ces chefs d'oeuvre de grâce et de beauté, ce visage touchant, cette tête pure, et ces charmes secrets que la pudeur ne laissa entrevoir jamais qu'à l'amour purifié par l'hymen. Les anges sont tombés, s'écrie-t-il enfin avec un cri sauvage ... (Le Mulâtre 100)

Féo's crime does not wake Stéphanie. Frustrated by Stéphanie's chemically-induced stupor and wanting her to know the identity of her attacker, the deranged Féo cuts off one of his fingers and leaves it on Stéphanie's bathroom sink attached to a cryptic note that sentences Stéphanie to a life of uncertainty and terror: "Juge de quoi a été capable I'homme qui ainsi a pu se mettre en pièces! . . Malheureuse, soupçonne tout, et existe!!!" (101)

Féo's attack on his former mistress results in Stéphanie becoming pregnant. The married comtesse gives birth to a baby boy whose livid complexion horrifies the new mother (130). The dark-complexioned baby immediately delights the hapless physician, who immediately sets about finding a scientific explanation for his dark color. After much reflection, Dr Vincent concludes that Etienne's color had to have been the result 
of Stéphanie's being struck by lightning during the early stages of her pregnancy (136). His explanation is delivered with such conviction that both M. Merval and Stephanie's husband are delighted with his pseudo-scientific discourse. (136 - 137). Accepting the doctor's explanation, the Clémingis family names the boy Etienne and attempts to adjust to the addition of a child to the household. However, this dark-complexioned child soon demonstrates a propensity for cruel behavior and manipulation:

Le caractère du petit Etienne se développait énergiquement avec le temps. Chaque année, chaque mois, je dirais presque chaque jour, voyaient naitre une mauvaise pensée ou une mauvaise action. Gai, aimable, caressant, flatteur, même avec le comte et M. Merval ; insolent, colère, boudeur avec sa mère, il était avec les domestiques et les paysans, dur, méchant et féroce. Plein de malice et d'esprit, il était devenu le surveillant de tout le château. (Le Mulâtre 139)

Etienne's behavior by far surpasses that of a spoiled child; he has a deep, inexplicable hatred of his mother. Stéphanie, representing la mère patrie, is in danger from le mulâtre, the mixed race individual that results from France extending freedom and education to slaves.

The Cléminigis marriage soon results in another child, a daughter that Stéphanie names Eugenie. Etienne's dark, sinister side is initially manifested in a dark, yet comical way against his younger sister. Eugenie is described from her birth as an exceedingly beautiful baby with blue eyes and exceedingly white skin; in other words, the phenotype of feminine whiteness. Etienne's first "attack" on his sister is to darken her perfectly white skin. While his sister sleeps, Etienne slips into her chamber with a childish plan to erase her whiteness:

Le méchant enfant avait sous sa veste une fiole remplie d'une couleur noire à l'huile semblable à celle qu'il avait vu mettre sur les voitures et dans différents endroits du château. Cette couleur qu'il croyait ineffaçable lui paraissait devoir servir 
merveilleusement ses desseins. Il en exprima quelques cuillerées sur une éponge qu'il tenait à la main, puis passant doucement cette éponge sur le visage d'Eugénie, il en fit en peu de temps la plus jolie négresse de l'Afrique (Le Mulâtre 144).

Etienne's actions are quickly addressed by la comtesse, who cleans off the harmless oil and presents the freshly washed Eugenie back to her brother. Emboldened by this lack of punishment and increasingly frustrated by the attention lavished on Eugenie, Etienne makes a much more sinister attack on his sister. Despising not only his sister's white skin but her blue eyes, Etienne devises a plan to hurt both his sister and his mother by focusing his attention on the beautiful blues which were the cause of his mother's constant pride.

An afternoon in the courtyard of the Clémingis castle nearly resulted in disaster for la comtesse and Eugenie. After playing with Eugenie, Stéphanie decides to put the infant down for a nap and leaves her sleeping daughter in the courtyard for a brief moment while she returned to the castle for a pillow. Etienne seizes the opportunity to once again attack the whiteness of his sister:

Il jette un regard malin sur sa sœur et fouillant précipitamment dans sa poche, il en tire une longue aiguille dont il examine la pointe avec un plaisir cruel; nous verrons si l'on parlera toujours de tes beaux yeux bleus, s'écrie-t-il. Il se baisse alors vers Eugénie et va percer les yeux de l'innocent enfant, lorsque la comtesse parait à l'entrée du bosquet. Elle voit l'intention d'Etienne, jette un cri terrible et s'élance sur lui. Il est sans doute trop tard, car Eugénie répond au cri déchirant. L'aiguille est enfoncée non dans l'un des ses yeux, la surprise a fait vaciller la main d'Etienne, mais dans le sourcil de la pauvre petite ... Etienne a disparu (Le Mulâtre 145)

The failed attempt to blind his sister showed only the surface of Etienne's pathological nature. Stéphanie orders her servants to find Etienne who, anticipating punishment, refuses to allow any of them to escort him back to his mother. Only one of Stéphanie's servants, Antoine, dares to physically bring the young child back to his 
mother. Stéphanie orders Antoine to beat Etienne, resulting in Etienne's plotting a terrible revenge. As soon as Etienne is allowed to play unsupervised in the park outside the Clémingis castle, Etienne gathers Antoine's son and a group of other young boys for an afternoon of games. Etienne proposes that they play "le bûcher" with Antoine's eight-year old son Joseph in the role of the pig. Tying the boy as if he were to be butchered, Etienne slices Joseph's neck and passively looks on as Joseph dies from exsanguination. Learning of Etienne's murder of his son, Antoine inflicts a series of injuries on Etienne, stopping just short of permanently injuring the boy. While $\mathrm{Dr}$ Vincent treats Etienne for multiple fractures and flesh wounds, the members of the Clémingis family wonder how they will live with a boy capable of murder. Three weeks after Joseph's murder, Antoine's body is found outside the Clémingis castle with wounds and fractures identical to the wounds inflicted on Etienne. The discovery of Antoine's body confirms Stéphanie's worst fears: Féo is still living in the French countryside and is watching the castle.

Despite the terror that reigns in the castle, Etienne remains with his family. Having developed a habit of solitary walks in the countryside, Etienne eventually meets his true biological father. Féo is living in a cave, his only companion a savage wolf named Zamor that Féo imagines being an instrument of racial justice: "Zamor . . . tu viens de faire sans doute un acte de justice. Puissent tous les blancs perir sous ta dent." (172) The terrifying wolf quickly becomes Etienne's fawning pet; soon the two are rolling on the cavern floor like a boy and a playful, completely domesticated house puppy. 
The introduction of the bloody wolf, playing as a puppy with the mulatto child, introduces a double of the mixed-race child who has just discovered the identity of his father. The wolf has killed what Féo announces was likely a white person; the young Etienne child has likewise killed a white playmate. In his book Gothic Images of Race in Nineteenth-Century Britain, H.L. Malchow describes the role the wolf plays in gothic literature:

The dog is an owned and mastered thing, fawning, loyal, and grateful; the wolf is a redeyed savage and threatening creature of folk myth, and the cross is suggestive, not of a tamed wolf, but of a demonized dog. As in the literature of the half-breed generally, such analogies have negligible scientific importance, of course, but considerable emotive significance. It is a comparison that elicits an essentially gothic response. The wolf or half-wolf became, in fact, a common trope for the threatening half-breed in the nineteenth century. Seeing the half-breed as a lone wolf, isolated from both communities that gave him birth, needless to say, suggests a familiar form of gothic monstrosity. (181, emphasis mine)

Etienne stays with Féo for several days during which Féo convinces Etienne of his complete alienation from the Clémingis family. Etienne's role, Féo convincingly states, is to avenge the purposeful humiliation of his true father:

Etienne, lui dit-il, tu es maintenant la seule espérance qui me reste au monde, ne va pas la détruire en laissant pénétrer dans ton cœur d'indignes faiblesses . . . Pense à moi, pense à mes injures, aux malheurs qui depuis douze ans m'ont accablé sans relâche, pense aussi au repoussement, au dégout, à l'aversion générale que tu inspires. Ta mère, n'en doute pas, connait le mystère de ta naissance, tout son amour est pour ta sœur et tu as hérité de l'horreur qu'elle me vouée (Le Mulâtre 175)

Having instructed Etienne to bring him the keys to the castle doors and to the bedchamber of le comte, Féo leaves Etienne in his cave and goes to the Clémengis castle one last time and murders Philippe de Clémengis. In Féo's mind, this crime secures his son's future as the head of the Clémingis family: “Etienne, tout est dit, s'écrie-t-il, il 
n'existe plus dans le monde qu'un seul et legitime comte de Clémengis. C'est mon fils ! Embrasse-moi, je le mérite." (186)

An observation of the above text shows that Balzac establishes Etienne's character as an instrument of vengeance for le bon nègre. The black male body, still connected to the representation of helplessness and exchange value, remains unable to realize any level of recognition or agency other than rape or murder. Etienne is not only the result of a Féo's crime, he is the embodiment of Féo's crazed desire to possess Stephanie. Féo's education informed him of the futility of this desire; his love for Stéphanie and his humanity will never be recognized by the Clémingis family. The educated black male who is not biracial has only one hope for recognition, and that is his mixed-race son. Le mulâtre gothique, therefore, has a much higher level of personal agency than the black male even thought that agency is realized through terror. The liminality of Etienne's existence (the eventual direction of his pathological behavior) is resolved by his association with his father; Etienne, now aware of his biracial heritage, will be the tool of Féo's demand for personal recognition.

Balzac realizes the height of terror in his novel by employing the romantic theme of incestuous desire. In his book Sick Heroes, Alan Pasco observes that the theme of incest in nineteenth-century French Romantic literature indicates the extreme instability of the post-Revolutionary France (214). I expand Pasco's argument and argue that the theme of incest in Balzac's novel serves to link the incest taboo to the fear of race-mixing in general and the danger the black male poses to the white female. Eugenie's entrance into adolescence is accompanied by her becoming a great beauty and a tender-hearted 
and overly trusting young woman. In spite of Etienne's murder of his playmate and attacks on her, Eugenie displays a deep level of sibling affection for her brother. Eugenie's naïveté makes her an extremely vulnerable to her brother's growing, incestuous desire:

Ma plume répugnait à le tracer; mais hélas il n'est que trop vrai; les grâces, la beauté touchante d'Eugenie, ont allumé dans le cœur d'Etienne un délire frénétique qu'il ose appeler du nom d'amour, salissant ainsi le plus tendre sentiment dont l'âme de I'homme soit susceptible. Etienne ose donc bruler pour sa sœur, et ce qu'il y a de plus effroyable c'est que cet amour indigne, criminel, en horreur aux hommes et à la religion, n'existe que dans des vues de honte et de turpitude, c'est la même ce qui lui donne sa force et son énergie (Le Mulâtre 202)

Féo's murder of Philippe de Clémengis leaves the entire household vulnerable not only to Etienne's manipulation and murderous pathology, but also to his incestuous lust for Eugenie. The educated and cultured black male, this time the gothic image of le mulâtre, is the heir apparent of the Clémengis castle. Etienne is tormented by his growing desire for his sister, and endogamy and exogamy are mixed. The heterotopia of the Clémengis castle, therefore, fulfills the gothic function of providing a space where history could conceivably repeat itself: Eugenie could become a victim of the same crime that her mother did at the hands of Féo.

Balzac neutralizes the threat posed by le mulâtre gothique with the introduction of another gothic character, le justicier. M. Merval de Savenage is informed of the death of a close family friend and becomes the guardian of Jacques de Kervens, the only son of a family of minor nobility in Breton. Courageous and handsome, Jacques de Kervens is nonetheless completely uncultured and the heir of an estate that is in complete disarray. Jacques becomes M Merval de Savenage's ward, and comes to the Clémingis 
castle with his faithful valet Bombeck. Unlike the rest of the inhabitants of the Clémingis castle, Jacques de Kervens seems to have the ability to confront Etienne and refuse to fall under his intimidation. Under the close tutelage of M. Merval de Savenage, Jacques quickly rebuilds his family fortune and falls in love with Eugenie. He manages to win Eugenie's affection by saving her from her brother's attempt to act on his incestuous desires. Having constructed a small cabin in the woods near the Clémingis castle, Etienne invites his sister to visit. Once inside, Eugenie is horrified to see the cabin is actually a torture chamber equipped with trap doors, moving walls and shackles. Hearing Eugenie screams, Jacques enters the cabin at the last moment:

On frappe violemment à la porte d'entrée, on la brise, on est dans la volière. Eugénie, alors, redouble ses cris malgré Etienne qui s'efforce de lui fermer la bouche avec un mouchoir. Un cri terrible répond aux cris d'Eugénie ; la porte, semblable à un verre fragile, vole en mille éclats et Jacques se précipite dans la chambre obscure. En l'apercevant, Eugénie se dégage des bras d'Etienne stupéfait et court se jeter dans les siens.

-Que faut-il que je croie ? s'écrie Jacques tremblant d'horreur. -Défendez-moi ! sauvez-moi M. de Kervens, Etienne veut me tuer. -Vous tuer ! non, non, reprend Jacques d'un air d'incrédulité; telle n'a point été son intention. Quoi qu'il en soit, ne craignez rien, mademoiselle, vous êtes sous ma protection et je périrai avant de souffrir qu'il vous soit fait la moindre violence. (Le Mulâtre 243-244)

Jacques's rescue of Eugenie establishes what I argue is the first role of le justicier in regards to le mulâtre gothique : le justicier prevents the possibility of further racial miscegenation. In the above text, Eugenie herself did not perceive Etienne's purpose; Jacques, however, understood that Etienne had planned a sexual assault. As Eugenie's protector, he becomes the protector of white femininity and blood purity that, in Balzac's text, represents French aristocracy and the plantation aristocracy of French colonies. The image of a courageous, noble-born hero who would protect white 
femininity would have resonated well in the years prior to Saint-Domingue's

independence, years in which the mixed-race population was blamed for the loss of France's most precious colony.

Immediately after Jacques and Eugenie's wedding, Stéphanie addresses Jacques and asks him to fulfill a "duty." This brings us to what I argue is the second duty of le justicier in la littérature gothique: to redeem any honor that the gothic hero or heroine might have lost to the gothic villain. The duty Stéphanie requests of Jacques is to defend her honor as la comtesse de Clémingis and a married woman at the time of her attack. Having changed from her gown into hunting dress, Stéphanie asks him to accompany her outside the castle:

Mon fils, dit-elle, la fortune et l'amour vous ont tout accordé, il faut maintenant que vous accordiez tout à l'honneur. Vous allez me suivre ; vous avez à sauver votre épouse, votre mère et votre père adoptif. Pendant que vous rempliez ce devoir sacre, M. Merval veillera sur Eugénie. Les moments sont précieux, venez (Le Mulâtre 274)

Jacques de Kervens summons the help of his valet Bombeck and a few soldiers.

Together, the small band quickly finds the cave where Féo has lived for years. The first enemy that the small band encounters is Feo's wolf, the gothic symbol of racial mixture that guarded the entrance to Féo's cave. Bombeck shoots the wolf and he, Stéphanie and Jacques enters Féo's dwelling. The three find Feo and Etienne after the wolf dies: La comtesse, Jacques et Bombeck se trouvent tous trois au milieu de la première habitation de Féo. Ils regardent de tous côtés et n'aperçoivent d'ennemis que le loup qui rend en ce moment le dernier soupir. La tapisserie du fond frappe Jacques, il va la franchir lorsqu'elle se relève brusquement et laisse voir le nègre et Etienne. La rage et le crime sont peints sur les traits de ces deux méchants. Etienne paraît blessé ; mais Féo possède toutes ses forces. (Le Mulâtre 277) 
The link between Etienne and the gothic image of the wolf is again established by the injury to the wolf and Etienne's heretofore unexplained injuries. The struggle that will soon take place between the four men is preceded by the revelation of Etienne's heritage. Standing wounded next to his father, Etienne finally admits his inexplicable hatred for his mother. Stéphanie's offer of mercy to Etienne results in the secret of Etienne's birth to be revealed to Jacques de Kervens and Bombek, and offers one of the few times in Balzac's text in which Etienne is referred to as a mulâtre. As le justicier, Jacques de Kervens is once again shocked by the idea of miscegenation, and quickly engages in a struggle to avenge such a great dishonor:

Etienne, ajoute-t-elle, vous que je n'ose plus nommer mon fils, je vous promets la vie et la liberté si vous abandonnez ce monstre.

-Je vivrai et je mourrai avec mon père, répond le mulâtre d'un air sombre . . . Femme ou plutôt démon, vous ne me tenterez point, car je vous hais.

-Son père! s'écria Jacques, quelle horreur infernale j'entrevois.

-Oui, son père, reprit Féo. La vertueuse Sténie fut à moi !

-Tu mens scélérat !

-Qu'il meure, qu'il meure !s'écria la comtesse dont les dents s'entrechoquaient avec force (Le Mulâtre 277)

The revelation of Etienne's birth results in a terrible battle between the four men.

Etienne's seems to admit and embrace his evil nature during his battle with Bombek.

Overpowered and defeated by Jacques de Kervens' powerful valet, Etienne chooses to take his own life rather than abandon his father and accept the results of his manipulations, murder and incestuous desires: "Etienne sourit amèrement . . . et rassemblant toutes ses forces, il se releva sur son séant et se frappe la tête sur le roc. Enfer! Enfer ! reçois-moi ! il dit et expira" (277). 
Etienne's death is quickly followed by the death of his parents. Maddened by the presence of her attacker and the murderer of her husband, Stéphanie de Clémingis is consumed by her desire to see Féo killed: "La comtesse, spectatrice forcée de cette lutte épouvantable, ne regardait que Féo. Perce-le, perce-le, mon fils, criait-elle à Jacques" (277). Jacques de Kervens' obedience to his mother-in-law, coupled with his own rage at the revelation of Etienne's birth, sends Jacques to fight Féo and avenge the honor of his family. Jacques is injured, but la comtesse dies:

Le nègre, se jetant alors à corps perdu sur Jacques, le renversa et, courant sur la comtesse, lui plongea son sabre dans le cœur ; mais avant qu'il l'eut retiré de sa plaie, avant que Bombek put accourir, Jacques se releva et d'un coup terrible fendit le crane du noir. Le scélérat tomba et perdit la vie en mugissant d'affreuses imprécations. L'infortunée comtesse jeta un dernier regard d'amour sur Jacques : je te bénis, mon fils, murmura-t-elle ; et son âme s'envola vers les demeures célestes. (Le Mulâtre 277)

Balzac adds an afterward to his novel, outlining the bright future of the remaining family. Under the protection of Jacques, now le marquis de Kervens, the family lives very prosperous and happy lives. Jacques and Eugenie have children who grow up under the tutelage of Doctor Vincent. Most of all, Jacques and his servant Bombek make certain that no-one, not even M. Merval or Eugenie, ever discovered the secret of Etienne's parentage.

Jacques et Eugenie, conservant toujours la plus tendre vénération pour la mémoire de la comtesse, ne crurent pouvoir mieux l'honorer qu'en associant son nom à tous les actes de bienfaisances et d'humanité qu'ils exercèrent. (Le Mulâtre 279)

The death of Stéphanie de Clemingis as the image of la mère patrie may seem contradictory to the idea that France needed a representation of colonial survival. However, it must be remembered that the image of la mère patrie is only one type of colonial history, one that attempted to share French identity with French colonies. This 
was characteristic of the approach to French colonialism in the areas that were under British rule during the French Revolution. When Guadeloupe and Martinique were returned to France in the Congress of Vienna, France was very uncertain what to expect from the black and mulatto population who had been under foreign rule for years. The colonial history of France was venerated under the Bourbon restoration, which sought in many ways to reestablish France as a powerful colonial presence. This history was sullied by the presence of le mulâtre (a symbol of shame for French culture) and the freed African slave (unable to successfully synthesize freedom and education). Le Mulâtre as a gothic novel, therefore, stands as a cautionary tale against assimilation taken too far, such as the assimilation attempted with the freed slave and mixed-race population in Saint-Domingue. Such assimilation is represented in Balzac's novel as a heterotopia of deviance, which attacked the blood purity of the French aristocratic family.

Le mulâtre gothique not only posed a threat to the French aristocratic family, he also posed a threat to French government as a whole. This idea is expressed, I argue, in Victor Hugo's historical novel Bug-Jargal.

\section{Hugo's Biassou : Le Mulâtre Gothique and the Crisis Heterotopia}

In Bug-Jargal, we see the second fundamental type of heterotopia, the crisis heterotopia. In Des Espaces Autres, Foucault describes crisis heterotopias as privileged, sacred or forbidden places for those individuals that are in crisis in relation to society (4). This definitely describes the image of le mulâtre in the French literary imagination of the 1820 's. In the remainder of this chapter, I will show how Hugo creates a space for le 
mulâtre that is neither the utopic vision of pre-revolutionary Saint Domingue nor the dystopic revolutionary Saint-Domingue. The image of le mulatre, embodied by many fictional representations of historical figures such as Jean Biassou, André Rigaud and Vincent Ogé, rise to power on the heels of the destruction of Le Cap and control the carnage of the revolution from a cave with serves as Jean Biassou's rebel headquarters. From this heterotopic space, le mulâtre re-orders society and is, ultimately responsible for the atrocities and excesses of 1791.

Hugo's Bug-Jargal is a "conte sous une tente," a tale of the life of a young Léopold d'Auverney narrated by an older, world-weary Léopold d'Auverney. Before the uprising, Saint-Domingue was an ideal location for the young d'Auverney. Originally from France, D'Auverney becomes the ward of his wealthy uncle. As a romantic hero, Leopold d'Auverney's character is too sensitive a soul to accept the abuse of the slaves on his uncle's plantation; however, he is still a wealthy white male who is part of the plantation system of France after 1789. Engaged to his cousin Marie and therefore the future heir of his uncle's plantation, Léopold d'Auverney is set for a brilliant future. For him, Saint-Domingue is a beautiful place that approaches perfection:

Peu d'hommes ont coulé plus heureusement que moi leurs premières années; peu d'hommes ont senti leur âme s'épanouir à la vie sous un plus beau ciel, dans un accord plus délicieux de bonheur pour le présent et d'espérance pour l'avenir. Entouré presque en naissant de tous les contentement de la richesse, de tous les privilèges du rang dans un pays où la couleur suffisait pour le donner, passant mes journées près de l'être qui avait tout mon amour, voyant cet amour favorise de nos parents, qui seuls auraient pu l'entraver, et tout cela dans l'âge où le sang bouillonne, dans une contrée ou l'été est éternel, où la nature est admirable ; en fallait-il plus pour me donner une foi aveugle dans mon heureuse étoile? (Bug-Jargal 41) 
Like the Merval de Sauvenage family in Balzac's novel, Léopold d'Auverney has a great deal of compassion for slaves on his uncle's plantation. He and his future bride made a habit of interceding on behalf of those slaves who were mistreated. The romantic hero of the text, therefore, is neither despot nor villain; he is a member of a utopic society ordered along racial lines.

Other than the cruelty that d'Auverney's uncle exhibits towards the plantation slaves, the only source of anxiety in d'Auverney's utopia is the possibility of racial mixture. D'Auverney has a particular revulsion for one of his uncle's slaves, a dwarf named Habibrah, a biracial slave of Spanish nationality. In spite of his general fondness for his uncle's slaves, D'Auverney is continually irritated by Habibrah's overly servile behavior and physical deformity:

"Ce nain hideux était gros, court, ventru, et se mouvait avec une rapidité singulière sur deux jambes grêles et fluettes, qui, lorsqu'il s'asseyait, se repliaient sous lui comme les bras d'une araignée." (39) Habibrah wins the favor of the plantation owner by being overly cruel to the other slaves; however, he seems to occupy a place of fear-inspired respect among the other slaves (40). Habibrah represents the physical product of miscegenation; a gothic monstrosity that represents a particular Enlightenment racial discourse of mulattoes that claimed racial hybrids would be infertile, physically weak and repulsive (Garraway 274). The threat of miscegenation even casts a pall over D'Auverney's romance with his cousin Marie. The night of 1791 (the day when bi-racial citizens of France were granted full civil rights), a nameless plantation owner happens to share a dance with Marie at a governor's ball. The plantation owner was rumored to be 
sang-melé, a bi-racial individual able to pass for white. The bi-racial plantation owner's presence among the other wealthy slave-owners of Saint-Domingue, along with his interest in Marie D'Auverney, establishes le mulâtre as a threat to both the economic power and family structure of French white masculinity in the novel. This threat would, according to the text, eventually result in catastrophe and bring an end to D'Auverney's utopic existence:

Les yeux fixés sur mon bonheur qui s'approchait, je n'apercevais pas le nuage effrayant qui déjà couvrait presque tous les points de notre horizon politique, et que devait, en éclatant, déraciner toutes les existences. Ce n'est pas que les esprits même les plus prompts à s'alarmer, s'attendissent sérieusement des lors a la révolte des esclaves, on méprisait trop cette classe pour la craindre ; mais il existait seulement entre les blancs et les mulâtres libres assez de haine pour que ce volcan si longtemps comprimé bouleversât toute la colonie au moment redouté ou il se déchirerait. (Bug-Jargal 44)

The idea of race-mixing is also suggested by the eponymous hero himself. Shortly before their wedding, Marie is serenaded in Spanish by a mysterious stranger who identifies himself as a slave, a king, and a black man. His song ends with the desire to produce a bi-racial child: "Tu es blanche, et je suis noir; mais le jour a besoin de s'unir a la nuit pour enfanter l'auroure et le couchant, qui sont plus beaux que lui!" (p 52) D’Auverney overhears Bug-Jargal's song, however, he does not know Bug-Jargal's identity until after the noble slave saves Marie from a crocodile attack and a fellow slave from a cruel beating. Arrested for striking a white person to spare his fellow slave, BugJargal awaits his execution. D'Auverney is able to secure Bug-Jargal's release by informing Marie's father that the slave has saved her life; as a result, Marie's father agrees to spare Bug-Jargal's life as a wedding present to the young couple. When BugJargal is informed that Marie's marriage occasions the stay of his execution, he cannot 
help but display his hurt emotions. It is here that D'Auverney starts to suspect that BugJargal might be his rival: "J'avoue que mes soupçons assoupis se réveillèrent, mais sans colère et sans jalousie. J'étais trop près du bonheur, et lui trop près de la mort, pour qu'un pareil rival, s'il l'était en effet, put exciter en moi d'autres sentiments que la bienveillance et la pitié" (69). A mutual respect is kindled between the two men; they begin to refer to each other as "frère." Discovering that Marie is D'Auverney's finance and the date of their wedding is August 22, Bug-Jargal warns D'Auverney to marry before that date. After delivering this enigmatic warning, the slave escapes the plantation. The fraternity established between the two seems to assuage D'Auverney's anxiety evoked by Bug-Jargal's nocturnal serenade, and D'Auverney once again enters a utopic existence.

The bliss of his marriage is interrupted by the attack on Le Cap, which takes place on August 22. D'Auverney is immediately summoned to duty as an officer in the colonial militia. D'Auverney immediately looks for orders from his superiors : "Je me rendis en hâte à l'hôtel du gouverneur, M. de Blanchelande. Tout y était dans la confusion, jusqu'à la tête du maître (78). The assembled political and military provide accounts of plantation owners killing their slaves for fear of their joining the rebellion. The artisan slave owners, les petit blancs, are accused of blaming the entire rebellion on the sangmêlé libres. D'Auverney is surprised to encounter the same plantation owner, rumored to be bi-racial, that had danced with Marie the night of the governor's ball. Blaming the rebellion on les sang-meles, the enigmatic planter does his best to encourage suspicion of the bi-racial population: "Les sang-melés sont nos pires ennemis. Eux-seuls sont à 
craindre pour nous." (81) The leaders of the various governing assemblies (provincial, national, general and colonial) cannot come to a consensus on the best plan of action. D'Auverney is witness to the dystopia that Saint-Domingue has become as one of the plantation owners, a renowned negrophile named le citoyen $C^{* * *}$, suggests murdering and decapitating several of the slaves that did not revolt as a deterrent to the mounting rebellion (86). The colonial leaders place the blame of this reversal of utopia as part of the French Revolution and the failures of the Enlightenment positions on slavery: Les philosophes ont enfanté les philosophes, qui ont procrée les négrophiles, qui produisent les mangeurs de blancs, ainsi nommés en attendant qu'on leur trouve un nom grec ou latin. Ces prétendues idées libérales dont on s'enivre en France sont un poison sous les tropiques ... Toutes les horreurs que vous voyez aujourd'hui à SaintDomingue sont nées au club Massiac, et l'insurrection des esclaves n'est qu'un contrecoup de la chute de la Bastille. (Bug-Jargal 84 - 85)

After much debate among the political and military leaders assembled at M . de Blanchelande's residence, D'Auverney manages to obtain his military orders and is plunged into the midst of the uprising. As a military officer, D'Auverney sees the massacre of white families and the widespread destruction of property, including the burning of his uncle's plantation.

Young and inexperienced as a soldier, D'Auverney is taken prisoner soon after the uprising and taken to the rebel headquarters. D'Auverney would now witness the site from which the rebellion is guided and meet the one responsible for the carnage: Jean Biassou. Biassou is presented in the text as a frightening liminal figure; he seems part human, part animal:

Le chef sacatra devant lequel j'étais introduit était d'une taille moyenne. Sa figure ignoble offrait un rare mélange de finesse et de cruauté. II me fit approcher, et me considéra quelque temps en silence ; enfin il se mit à ricaner à la manière de l'hyène. 
-Je suis Biassou, me dit-il.

Je m'attendais à ce nom, mais je ne pus l'entendre de cette bouche, au milieu de ce rire féroce, sans frémir intérieurement. (Bug-Jargal 119)

Biassou's environment, as well as his person, is a complex and confusing mixture of

symbols. A sacara, Biassou is a dark-skinned mulatto of more African than white

ancestry. Hugo describes Biassou's costume in detail:

Son costume était ridicule. Une ceinture magnifique de tresse de soie, à laquelle pendait une croix de Saint-Louis, retenait à la hauteur du nombril un caleçon bleu, de toile grossière; une veste de basin blanc, trop courte pour descendre jusqu'à la ceinture, complétait son vêtement. Il portait des bottes grises, un chapeau rond, surmonté d'une cocarde rouge, et des épaulettes, dont l'une était d'or avec les deux étoiles d'argent des maréchaux de camp, l'autre de laine jaune. Deux étoiles de cuivre, qui paraissaient avoir été des molettes d'éperons, avaient été fixées sur la dernière, sans doute pour la rendre digne de figurer auprès de sa brillante compagne. Ces deux épaulettes, n'étant point bridées à leur place naturelle par des ganses transversales, pendaient des deux côtés de la poitrine du chef. (Bug-Jargal 118)

Biassou's ill-fitting, makeshift uniform underlines the liminality of his character. The effective raids on the Saint-Domingue plantations and successful sacks of French colonial military forts seem unlikely under the leadership of such a ridiculous figure; one who is unable to even put together a uniform that would command the respect of a French military officer. A portrait of the mulatto rebel leader Vincent Ogé is placed over Biassou's seat, connecting the history of rebellion to the leadership of mulattoes.

Biassou also places military standards, guidons and national flags in a haphazard manner around his seat, displaying either a lack of understanding of military standards or a lack of national loyalty. In his book Islands and Exiles, Chris Bongie explains Hugo's portrayal of Biassou:

As soon becomes clear, what is primarily at stake in the representation of Biassou is the fate of representation itself. Biassou becomes the figure through whom Hugo can explore, and yet at the same time (attempt to) dispel, one of the commonplace 
anxieties of postrevolutionary writers: namely, that arising from the evaporation of an authentic connection between signs and their referents, the melting of all that is solid into air. (Bongie 242)

I expand Bongie's argument by suggesting that Biassou as le mulâtre gothique occupies, and is actually the individual who controls, a crisis heterotopia. Biassou's appearance and environment may very well be assembled in haphazard manner, but every detail is based on mimicry of existing elements of military power. As a result, Biassou wields a power that D'Auverney finds terrifying because it is outside of his control. However, each tactic that Biassou employs from this heterotopic space is an attempt to mimic what he perceives as French culture. In his book chapter "Space, Discourse, Power: Heterotopia as Analytics," Derek Hook notes that signs and referents are dissociated in heterotopic spaces, resulting in a text that evokes similitude rather than certainty:

Similitude works on the basis of unexpected or unusual associations. In a relation of similitude there is no obvious code, no direct referent and no immediate or obvious translation. Rather than solidifying a stable relation of reference, similitude is thus about the effects of juxtaposition, of bricolage, which confound the attempts to read a regular or stable code of meaning $(187,188)$

The destruction of any dependable code of meaning not only reflects the liminality of Jean Biassou, it serves to create a mood of complete terror for the reader. The position of black masculinity (incarnated in le mulâtre) in a position of military power over white masculinity is seen as evoking horror and, in this case, complete powerlessness (Hetherington 40).

Léopold D'Auverney is forced to kneel and witness a pagan re-enactment of a Catholic mass and a military address by Biassou to the rebel slaves. He finds himself both repulsed and fascinated by the effect Biassou has on the rebel slaves, who show 
their support of the rebellion in all manner of frenzied behavior: beating their chests, brandishing weapons and playing musical instruments. Biassou's apparent concern for the soldiers, however, is soon exposed as cruel manipulation of desperate and uneducated slaves. Biassou's religious leader begins to tend to the medical needs of the wounded rebels. The helpless rebel soldiers suffer greatly due to the lack of medical attention given to them, which consists of a combination of folklore medicine and voodoo ceremony. D'Auverney sees that the efforts of the rebel leadership only serves to make the rebel followers believe in the supernatural powers of their religious leader (129). As a result, Biassou is represented as a leader who is the embodiment of cruelty, using black rebel slaves to enact vengeance on the French colony.

The heteropic space of Biassou's cave, like the heterotopic space in Balzac's Le Mulâtre, serves as a place where the excesses of eighteenth-century thought are examined. Biassou conducts an interrogation of three characters that, I argue, represent three aspects of life in pre-revolutionary Saint-Domingue: slavery, negrophile philosophy, and racial categorization:

Le mariscal de campo leur imposa silence d'un signe de main, et fit avancer les trois captifs sur le seuil de la grotte. J'en reconnus deux avec surprise ; l'un était ce citoyengénéral $C^{* * *}$, ce philanthrope correspondant de tous les négrophiles du globe, qui avait émis un avis si cruel pour les esclaves dans le conseil, chez le gouverneur. L'autre était le planteur équivoque qui avait tant de répugnance pour les mulâtres, au nombre desquels les blancs le comptaient. Le troisième paraissait appartenir à la classe des petits blancs ; il portait un tablier de cuir, et avait les manches retroussées au-dessus du coude. (BugJargal 144)

The character in the leather apron is a carpenter who also happens to be Biassou's former master. The captive, Jacques Belin, infuriates Biassou by refusing to salute him. He then further insults Biassou by publically reminding him of his slavery: "Tu feins de 
me méconnaitre; mais souviens-toi, Jean Biassou, je t'ai vendu treize piastres-gourdes à un marchand domingois." (145) Biassou commands that the carpenter be sawn in pieces, a sentence which terrifies D'Auverney. Belin, however, refuses to give Biassou the satisfaction of showing fear and goes to his death with another insult: "Oui, dit-il, je dois te remercier, car je t'ai vendu pour le prix de treize piastres, et tu m'as rapporté certainement plus que tu ne vaux." (146). It becomes clear in the text that Biassou's goal is neither justice nor freedom, but rather enacting bloody and humiliating acts of revenge. Biassou's gothic pleasure at the death of his former slave-master calls the right of rebellion into question; therefore, Hugo's text doesn't condemn the Saint-Domingue revolution itself, but does condemn the excesses of the revolution, which he lays at the feet of the mulatto leaders.

The second prisoner that faces Biassou is le citoyen-general $\mathrm{C}^{* * *}$, who immediately begins to flatter Biassou in hopes of gaining his mercy. The title "negrophile" disturbs Biassou, who takes pleasure in badgering the prisoner:

-Négrophile, interrompit le généralissime: qu'est-ce que c'est qu'un négrophile? -C'est un ami des noirs, balbutia le citoyen. -Il ne suffit pas d'être ami des noirs, repartit sévèrement Biassou, il faut l'être aussi des hommes de couleur. -Je crois avoir dit que Biassou était sacatra. -Des hommes de couleur, c'est ce que je voulais dire, répondit humblement le négrophile. Je suis lié avec tous les plus fameux partisans des nègres et des mulâtres... Biassou, heureux d'humilier un blanc, l'interrompit encore : - Nègres et mulâtres ! qu'est-ce que cela veut dire ? Viens-tu ici nous insulter avec ces noms odieux, inventés par le mépris des blancs ? Il n'y a ici que des hommes de couleur et des noirs, entendezvous, monsieur le colon? (Bug-Jargal147)

The above text indicates a desire for recognition on the part of Biassou by the colonial system. Biassou's rejection of the words nègre and mulâtre is a refusal of the stigma of 
slavery and illegitimacy that these terms carry; the terms hommes de couleur and noir connote the status of legitimate citizens. The exchange between Biassou and le citoyen $C^{* * *}$ ends as Biassou divulges his intelligence of the negrophile's actions:

Je te connais! Comment as-tu été assez stupide pour ne pas t'en apercevoir? C'est toi qui as présidé aux supplices de juin, de juillet et d'aout; c'est toi qui as fait planter cinquante têtes de noirs des deux côtés de ton avenue, en place de palmiers; c'est toi qui voulais égorger les cinq-cents nègres restes dans test fers après la révolte, et ceindre la ville du Cap d'un cordon de têtes d'esclaves, du fort Picolet à la pointe Caracol. (BugJargal 154)

The gothic character Biassou, in the above text, exposes the hypocricy of the band of negrophiles who were popular at the end of the eighteenth-century. French national interests were greatly tied to a strong French colonial system, which resulted in a group of negrophiles who were actually very much in favor of suppressing revolution at all costs. The heterotopia of Biassou's cave permits a text in which a former slave has the ability to expose the hypocrisy of the French negrophile philosophy.

The final character interrogated by Biassou represents the colonial system of racial hierarchy. Biassou and André Rigaud confront the same bi-racial planter that D'Auverney confronted and dueled the night of the governer's ball and encouraged suspicion of les sang-melés at Blancheland's residence. Now a prisoner of the uprising, the unnamed planter claims that he is a mulatto, and therefore belongs among Biassou's rebels. Accused of being a white plantation owner and desperate to prove his bi-racial ancestry, the character shows his fingernails:

-Je n'ai point d'autre gloire et d'autre bonheur que d'appartenir aux noirs. Je suis un mulâtre! -Si tu étais un mulâtre, en effet, observa Rigaud paisiblement, tu ne te servirais pas de ce mot. 
-Hélas ! sais-je ce que je dis ? reprenait le misérable. Monsieur le général en chef, la preuve que je suis sang-mêlé, c'est ce cercle noir que vous pouvez voir autour de mes ongles (Bug-Jargal 156 - 157)

The reference to the darkened half-moon circling in Hugo's text is quite significant as a theme of bi-racial ancestry. The myth of bi-racial ancestry shown in the fingernails becomes a common theme in literature between 1840 and 1950, and Hugo was one of the first Romantic writers to exploit this image as a racial determiner and part of the mulatto phenotype:

As a motif, the fingernail as a racial sign is sometimes linked with other signs that transform the body into a text and that are presumed to be racial indicators - such as hair, skin, or eyes; the sign is strongly determined racially, and the instances where even its absence functions as a racial marker suggests that some of the texts implies a reader who shares certain ideas about race (Sollors 151)

In his book Neither Black Nor White: Thematic Explorations of Interracial Literature, Werner Sollors traces the use of the fingernail motif to Enlightenment thinkers and anatomists Alexis Littré, Count Georges Louis Leclerc de Buffon and Jean-Baptiste Labat. These three eighteenth-century writers all claimed that children with black ancestry will always retain black markings either on their fingernails or, if they are males, their genitals. The image of darkened fingernails as a part of mulatto phenotype appears in the work of Eugene Sue and Mme de Reybaud. As one of the first to exploit such a motif as a racial marker of blackness in mixed-race individuals, Hugo may have set a precedent of racial discourse:

Hugo's choice was all the more momentous since his text may have held the position of a funnel that gathered forms of other discourses and utilized them, however contradictorily, in fiction; his work, through the dissemination of Revue de Paris novellas (like Les Épaves) and feuilleton fiction (like Les Mystères de Paris) may thus have been one literary ur-text of the motif under scrutiny. (Sollors 157) 
Unconvinced of the racial identity of the anonymous planter, Biassou instructs him to prove his alliance to the rebel cause by killing two white Frenchmen: Leopold D'Auverney and le citoyen $C^{* * *}$. Seeing his initial terror and reluctance, Biassou calls for him to be taken: "Fort bien! Dit Biassou en se tournant vers les nègres; il ne veut pas être bourreau, il sera patient. Je vois que c'est un blanc ; emmenez-le, vous autres ..." (158) The text links cruelty, cold-blooded nature, with the mixing of race. Seeing that he is about to be killed himself, the unnamed planter seizes the dagger and attacks le citoyen $\mathrm{C} * * *$. Unaware of the arrangement that provoked the attack, le citoyen $\mathrm{C} * * *$ exposes the planter's previous race passing:

- Épargnez-moi! Vous m'en voulez peut-être de ce que j'ai dit autrefois que vous étiez un sang-mêlé? Mais laissez-moi la vie, je vous proteste que je vous reconnais pour un blanc. Oui vous êtes un blanc, je le dirai partout, mais grâce !

Le négrophile avait mal choisi son moyen de défense.

- Tais-toi ! tais-toi! Cria le sang-mêlé furieux, et craignant que les nègres n'entendissent cette déclaration.

Mais l'autre hurlait, sans l'écouter, qu'il le savait blanc et de bonne race. (Bug-Jargal $158-159)$

Satisfied that the anonymous planter would be loyal to his cause, Biassou spares D’Auverney's life and names the planter a "good brother" and "bourreau de notre armée" (160). The heterotopia of Biassou's cave is the place where the unnamed sangmêlé receives both a name and a group affiliation that resolves his liminality. Along with le mulâtre gothique embodied by Biassou, the bi-racial planter displays the treacherous and cold-blooded nature of le mulâtre.

Like Balzac, Hugo neutralizes the threat of le mulâtre gothique with the image of le justicier. Also like Balzac, Hugo assigns le justicier the role of confronting le mulâtre gothique, ending the anxiety presented by possible racial contamination and redeeming 
the honor of the hero. A rebel leader of the band at Mourne-Rouge, Bug-Jargal earns a reputation as a courageous leader and humane rebel. Biassou notes that Bug-Jargal's leadership has influenced the band of rebels that he leads; a group who are, not incidentally, not mulattoes: "Je les hais; ce sont Presque tous des congos! Et puis ils ne savent tuer que dans le combat; idole Bug-Jargal, jeune fou qui voulait faire le généreux et le magnanime." (166). Despite his leadership and military acumen, Bug-Jargal eventually falls into the hands of the colonial militia; fortunately, he soon manages to escape and find Biassou's military headquarters. In Biassou's cave, Bug-Jargal learns of Boukmann's death. The eponymous hero proceeds to confront Biassou and Rigaud, reproaching them for their inhumane actions. Bug-Jargal states the death of Boukmann is just: "Ecoutez-moi, Jean Biassou: ce sont ces cruautés qui perdront notre juste cause. Prisonnier au camp de blancs, d’où j'ai réussi à m'échapper, j'ignorais la mort de Boukmann, que vous m'apprenez. C'est un juste chatiment du ciel pour ses crimes." (188) The details of Bug-Jargal's reproach start by accusing mulattoes of abusing religion to gain the trust of the rebel slaves:

Il y a au Trou-Coffi un charlatan mulâtre, nomme Romaine-la-Prophétesse, qui fanatise une bande de noirs ; il profane la sainte messe' il leur persuade qu'il est en rapport avec la Vierge, dont il écoute les prétendus oracles en mettant sa tête dans le tabernacle ; et il pousse ses camarades au meurtre et au pillage, au nom de Marie! (Bug-Jargal 189)

In the above text, Bug-Jargal is used to condemn the abuse of religion to motivate rebels to murder. Hugo's use of I'esclave royal (see Chapter Two) places the abuse of religion squarely at the feet of the mulatto leaders instead of the black rebels overall.

Bug-Jargal calls Biassou to a more humane form of rebellion, stating that the white plantation owners are less cruel than the rebels. Their interest in their slaves is, Bug- 
Jargal admits, motivated more by financial interest than their concern for the well-being of the enslaved; however, the end result is that they appear more compassionate and able to listen to reason. The atrocities committed by the rebels, on the other hand, pose the danger of leaving a legacy of senseless violence:

Notre cause sera-t-il plus sainte et plus juste quand nous aurons exterminé des femmes, égorgé des enfants, torturé des vieillards, brulé des colons dans leurs maisons? Ce sont la pourtant nos exploits de chaque jour. Faut-il, répondez, Biassou, que le seul vestige de notre passage soit toujours une trace de sang ou une trace de feu ? (Bug-Jargal 190)

Even as an escaped prisoner of war far below Biassou's position, the force of BugJargal's words is delivered in a manner similar to an adult rebuking a willful, mischievous child. Face to face with Bug-Jargal, Biassou loses his comportment and acts like a cornered animal: "Comme un renard pris par un lion, l'œil obliquement baissé de Biassou semblaient chercher par quelle ruse il pourrait échappé à tant d puissance." (190) Like Jacques de Kervens, Bug-Jargal seems to be the only one in the heterotopic space with the ability to see and confront the villainous action of le mulâtre gothique.

Bug-Jargal's confrontation with Biassou (representing Hugo's use of fiction to interrogate History) is followed by Bug-Jargal's fulfilling the dual roles of le justicier confronted with le mulâtre gothique. The first role, which is to prevent miscegenation, is complex in Hugo's novel due to the fact that the theme of race-mixing is presented by Bug-Jargal himself. The confrontations that take place between black and white masculinity involve one white woman who, like Stephanie Merval in Le Mulâtre, seems to become "every woman" by the lack of other female characters in the novel. BugJargal was indeed in love with the beautiful Marie, and made certain that she was safe when her father's plantation was burned. Léopold D'Auverney happened to have 
witnessed Bug-Jargal's rescue of Marie, and misinterpreted what he saw: “En ce

moment un grand noir sortit de derrière une palissade enflammée, emportait une jeune femme qui criait et se débattait dans ses bras. La jeune femme était Marie ; le noir était Pierrot. Perfide! Lui criai-je." (91 - 92) Notions of fraternity between the two men are replaced by the image of Marie being abducted by the man who had previously saved her from a crocodile. The hero now represents the terror of interracial sex. In his book Victor Hugo and the Visionary Novel, Victor Brombert observes the image of miscegenation that Bug-Jargal represents for Leopold d'Auverney, an image that seems to be confirmed by what $D^{\prime}$ Auverney sees:

There can be no doubt that the French officer sees the powerful, muscular Bug as the figure of the "phallic negro." Sexual violence seems to be a constant threat. When the gigantic negro carries off the Frenchman's bride to save her from the flames, the vision is that of abduction, if not rape (22)

As le justicier, Bug-Jargal puts D'Auverney's anxieties to rest by taking him to the hiding place where Bug-Jargal has kept her safe. The reunion of the newlyweds is torture for the noble rebel leader:

-Léopold, dit-elle, mon Léopold!

-Marie! ... répondis-je; et le reste de nos paroles s'acheva dans un baiser. -Pas devant moi au moins! s'écria une voix déchirante.

Nous levâmes les yeux : c'était Pierrot. Il était là, assistant à nos caresses comme à un supplice. Son sein gonflé haletait, une sueur glacée tombait à grosses gouttes de son front. Tous ses membres tremblaient. Tout à coup il cacha son visage de ses deux mains, et s'enfuit hors de la grotte en répétant avec un accent terrible : - Pas devant moi !

Marie se souleva de mes bras à demi, et s'écria en le suivant des yeux : -Grand Dieu ! mon Léopold, notre amour parait lui faire mal. Est-ce qu'il aimerait ?

Le cri de l'esclave m'avait prouvé qu'il était mon rival ; l'exclamation de Marie me prouvait qu'il était aussi mon ami. (Bug-Jargal 198)

The "voix déchirante" places Bug-Jargal textually as "the voice" that serenaded Marie from her garden. Bug-Jargal's nobility in rescuing another man's wife and the lengths 
that he went to in order to reunite the two, despite his love for Marie (199) establishes

Bug-Jargal as one too noble to act in his own interests. The entire threat of miscegenation, introduced by Bug-Jargal's presence early in the novel, is dispelled by his role as le justicier.

The second duty of le justicier, that of redeeming the honor of the hero, is accomplished on the heels of D'Auverney's trust of Bug-Jargal. D'Auverney obtained permission to leave Biassou's camp with the solemn promise that he would return two hours before sunset. He remembers his promise three hours before sunset:

Il faillait une bonne heure pour me rendre au camp de Biassou. - Mon devoir était impérieusement prescrit; le brigand avait ma parole, et il valait mieux encore mourir que de donner à ce barbare le droit de mépriser la seule chose à laquelle il parut se fier encore, l'honneur d'un français." (Bug-Jargal 206-207)

Having been reunited with Marie, the only way he could keep his promise to Biassou was to entrust his bride to Bug-Jargal's safe-keeping. Bug-Jargal agrees to take Marie to a colonial camp, where he is told to go back and save D'Auverney's life. Ten rebel soldiers would be killed if Bug-Jargal failed to save D’Auverney. Bug-Jargal rushes back just in time to save D'Auverney from death at the hands of Habibrah. Bug-Jargal then returns to save the ten prisoners, but is killed when D'Auverney does not arrive at the camp in time to prove the success of Bug-Jargal's mission. Biassou hoists a black flag from the top of a mountain, announcing the execution of Léopold D'Auverney. In grief and rage, D'Auverney's aide-de-camp executes Bug-Jargal. The eponymous hero does indeed help D'Auverney redeem his honor in front of Biassou, but ultimately gives his life to do so. Léopold D’Auverney's friendship and abiding veneration of Bug-Jargal 
underlines the treachery of le mulâtre gothique, who is portrayed in the text as directly responsible for the uprising and indirectly responsible for the death of Bug-Jargal.

In conclusion, this analysis of le mulâtre gothique is greatly connected with the history of the early Bourbon Restoration. The heterotopic spaces that this literary image occupies are a condensation of France's history with Saint-Domingue. In both of the novels under consideration in this chapter, the history of France's relationship with her most valuable colony is condensed into the life of one character, either Stéphanie de Sauvenage or Léopold D’Auverney. Both characters represent aspects of France before the Saint-Domingue uprising: the French aristocratic family, and the post-revolutionary French Republic. It must be remembered that Saint-Domingue was not France's only colonial holding, it was simply the most valuable colonial holding. The crippling loss of Saint-Domingue and the terrors of the uprising were remembered in tension with the rest of France's colonial holdings in Guadeloupe, Martinique, Reunion, and Mauritius where France had established a republican colonial family romance. The portrayal of le mulâtre as a gothic monster, wreaking havoc in French families and government, appealed to a large French reading public as they attempted to deal with a past that was still a present anxiety. The gothic seems to be the most appropriate genre to explore the contradictory aspects of negrophobia with the ideals of French republicanism. The complicated position of these novels, then, is how to represent a fear of race-mixing during a time in French history where France was desperately seeking to define itself in clear terms. The best way to represent the terror of racism was to project it on the 
indeterminate figure of le mulâtre, the image scapegoated for France's humiliating and costly loss:

In general, these deep fears and longings in western readers that the Gothic both symbolizes and disguises in "romantic" and exaggerated forms have been ones that so contradict each other, and in such intermingled ways, that only extreme fictions of this kind can seem to resolve them or even confront them (Hogle 4)

I argue that these novels display an anxiety concerning France's colonial history during the early nineteenth century. This was a complicated time to examine this aspect of France's history, as France was simultaneously a post-colonial and a colonial European power. France's need to accept and resolve her past colonial losses while at the same time garner support for her current colonial holdings necessitated a scapegoat; one that could be blamed not only for the independence of Haiti but also the atrocities that had by the mid-1820's become legend in the mind of the French reading public. Le mulâtre, a racially indeterminate being whose very existence seemed to transgress natural boundaries, was the perfect image for that end.

In this chapter I have examined le mulâtre as a gothic character that disturbed French history by his association with a heterotopic space. Two other images of mixed-race masculinity are the oedipal son and the mulatto guilty of fratricide. These images are formed by Freudian concepts of the Family Romance. I will explore these two images of le mulâtre in Chapter Four. 
Chapter Four: All in the Family? The Patricidal and Fratricidal Imagery of Le Mulâtre Tragique

French romanticism was a product of the French revolution. The characteristic traits of French romantic literature; le mal du siècle, the search for le moi, the image of the extraordinary individual and his quest for greatness, travel, exoticism and a nostalgia for the past resulted from the overthrow of I'ancien régime and the search for another political system that could take its place. The fall of I'ancien régime was also, in politics as well as in literature, a fall of the patriarchal system that had been France. In her book The Family Romance of the French Revolution, historian Lynn Hunt studies the French Revolution as an adaptation of a Freudian Family Romance, the latter a model the psychological state of a child who, dissatisfied with his biological parents, images parents better suited to fulfill the child's desires. As applied to the politics of the French Revolution, however, the family romance takes on a different connotation. Hunt states: "Family Romance is defined in the context of the revolution as the collective, unconscious images of the familial order that underlie revolutionary politics." (xiii) The Freudian family romance of the French Revolution, according to Hunt, required the removal of the oppressive father figure so that France could be a nation of liberté, égalité et fraternité. This disenchantment with paternity and removal of the father figure had a large impact on the literature of late eighteenth and early nineteenth century France, which often portrayed father figures as despotic and tyrannical. This type of literature took on several forms after 1795 , not only sentimental and romantic, but also grotesque and gothic. The major character of French Romanticism was the 
young man, often a bastard or an orphan, who realized a sense of agency by righting the wrongs of his father, refusing his father's way of life, or even rebelling against his father. This literary pattern resulted in an interesting portrayal of le mulâtre, almost always the son of a white father and a black mother in the French literary imagination. As I have argued in Chapter Two, The Literary Representation of the Black Male Body, the literary mulatto distinguishes himself from the other basic tropes of black masculinity due to his claim to agency, which I define as his ontological quest for identity and his demand for recognition. If his efforts to realize his agency achieve a level of success, as I will argue in Chapter Five, we can classify him as le mulâtre romantique, so called because this literary character represents the black masculine who manages to lay claim to agency in common romantic literary codes and traditions (the Byronic hero, the early romantic hero who suffers from and manages to resolve his mal de siècle, the dandy and the trickster). If, however, the literary mulatto's efforts to achieve agency and recognition are not realized, I argue that we can classify him as le mulâtre tragique, so called because the very efforts to realize a sense of personal agency and demand for recognition culminate in his death but also are accompanied by images of patricide and / or fratricide. This is the case in the two texts under consideration in this chapter, Victor Séjour's short story Le Mulâtre (1836), the tale of Georges, an enslaved mulatto son who unknowingly kills his father and Victor Hugo's historical novel Bug-Jargal (1826). Written during the height of French romanticism, both texts are fictional accounts of the Saint-Domingue revolution and present mulattoes as principle characters who, after having suffered unimaginable indignities, encourage and commit 
either literal or symbolic parricide and / or fratricide. This quest for agency and the death of le mulâtre in France's nineteenth century literary imagination is, I will argue, the result of a family romance particular to France's colonial holdings.

\section{The Colonial Family Romance and The Mulatto's Special Oedipal Triangle}

Lynn Hunt's use of Freud's conception of the family romance has particular application and multiple layers of meaning to the relationship between France and France's colonial holdings, populated by grand and petit blancs, des gens de couleur libres, and slaves both black and mulatto. The fall of l'ancien régime and the replacement of the father figure that represented the ancient regime were, to the gens de couleur libres, the removal of the system that for decades had embraced several methods of maintaining them as second-class citizens and denying them full rights as members of I'Assemblé Nationale. To the enslaved population, both mulatto and black, it meant the promise of freedom, a hope that seemed to be realized with the abolition of slavery in 1789. This hope was disappointed with the reinstitution of slavery throughout France's colonies by Napoleon in 1802 and the reestablishment of Le Code Noir. An important change in the dynamics of family romance occurred with the establishment of Imperial France, during which time the image of the paternalism that had been gradually effaced before the French Revolution was explicitly rehabilitated (Hunt 152). The family romance of Republican France clearly no longer meant liberté, égalité, et fraternité in a universal or Enlightenment sense, and metropolitan France needed a modified family romance, a colonial family romance that would define, in Hunt's words, the familial structures that underlay politics. Interestingly, this colonial 
family romance has been defined in two different manners. Francoise Vergés and Doris Garraway both posit a version of the colonial family romance that seem to vary in accordance with specific colonial holdings and their place in French colonial history.

In her book Monsters and Revolutionaries: Colonial Family Romance and Métissage, Françoise Vergés argues that the colonial family romance replaced the patriarchal order of l'ancien régime with the concept of La Mère-Patrie, an image of the protective yet castigating mother. La Mère-Patrie was imagined as the devoted mother figure to which colonial children would be forever indebted for bringing civilization to their coasts. Because this debt was constituted on French ideals of republicanism, revolution, and Enlightenment, this particular version of colonial family romance included the colored population into France's post-revolutionary family, although racial inequalities were still an integral part of this imagined post-revolutionary colonial family dynamic (Vergés 6). This seems to be the colonial family romance that took root in Guadeloupe, Réunion, Mauritius and Martinique. Vergés comments on the success of this version of the family romance in Réunion:

The fraternal bond dreamed by metropolitan brothers was affected by colonialism and its logic of racism. Colonized men might be their brothers, but they were their little brothers ... Yet this fiction was adopted by Reunion's educated colored, intellectuals, workers, and peasants. They imagined themselves as the brothers of French citizens. (Vergés 5 , emphasis mine)

Vergés notes that the establishment of La Mère-Patrie as the head of a colonial family romance also hides the reality of slavery in the reality of métissage. Instead of an abusive white patriarchal system that established rule over a slave population bought in India, Madagascar and Africa, France's colonies were under the protection of a caring 
but strict parent. Slavery and métissage, therefore, became le secret de famillie. (Vergés

9) Rebellion was, as a result, seen as the ingratitude of children to one parent who had lavished maternal affection on her children.

The second version of the colonial family romance, provided by Doris Garraway in her book The Libertine Colony, is actually an interpretation of Moreau de Saint-Mery's Description de la partie francaise de l'isle de Saint-Domingue. In Garraway's study, the colonial family romance is described as the white male slave-owner, the black or mulatto mother, and the mixed-race offspring. This version of the colonial family romance has, in Garraway's view, important sociological and political implications as it positions the white male as the origin of society:

Especially significant is Moreau's forceful claim of biological paternity over the class of mixed race ... In Moreau's colonial imaginary [ ... ] what becomes important is [precisely] the genetic claim of white paternity, a gesture that disgraces the class of free colored people as the master's bastards. His declaration of filiation thus offers a discursive means by which to co-opt the power of mulattoes and free people of color by claiming responsibility for them. (Garraway 275-76)

Garraway's usage this interpretation of the colonial family romance provides a model that she uses to explain the politics of sexual libertinage in the French Caribbean during the eighteenth and nineteenth centuries. The concept of libertinage in a slave society, as Garraway explains, not only provided the slave owners with an endless supply of manual labor to exploit but also furnished the white slave master with an endless supply of black and colored women for his sexual exploitation. The concept of women as legal property with no rights to her personhood or body redefined libertinage in France's colonies and legitimated the sexual pursuit of the colored woman by the white male, whether she was the daughter of the white male or not. 
I argue that this interpretation of Saint-Mery's ethnography offers compelling insight in how France remembered the loss of Saint-Domingue in early nineteenth century fiction. Saint-Mery's attempt at racial classification not only makes the mulatto woman a legitimate object of white male libertinage (and thereby legitimizes incest between the white father and his mulatto daughter), but makes the mulatto woman the desired endpoint of interracial reproduction. Sensual, beautiful and mythologized as being sterile, la mulâtresse was the perfect concubine and became in literature the figure responsible for the lax morals and excessive financial expenses in France's colonies. However, what would happen if the mixed-raced offspring were a male? Garraway's interpretation of the colonial family romance not only figures la mulâtresse as the endpoint of colonial libertinage; it also draws an Oedipal Triangle that places the male mulatto in the position of the oedipal offspring. Because the black male is not included in Garaway's version of the colonial family romance, the only parental figure le mulâtre could rebel against in his ontological quest for significance is the white male and / or what the white male represented; specifically France's slave system, the lack of filial recognition by the white father, and the degradation of the black or mulatto woman. This colonial family romance became very important after Napoleon's re-establishment of slavery in 1802 throughout France's colonial territories. The reestablishment of paternity, slavery and Le Code Noir would motivate the black enslaved male population that existed outside the colonial family romance to rebellion against an unjust and oppressive political system. This was the very reaction of France herself in 1789. Garraway's version of the colonial romance, however, places revolution on the part of 
either les gens libres de couleur or the mulattoes as parricide, a certain type of oedipal rebellion unique to the male mulatto. The rebellion of le mulâtre evoked a particular type of anxiety because his rebellion was not just rebellion against slavery and political oppression, it was a rebellion against the mulatto's symbolic, and possibly biological, father. The Saint-Domingue uprising turned this anxiety into a historical reality. As Marlene Daut states in her article "Sons of White Fathers: Mulatto Vengeance and the Haitian Revolution in Victor Séjour's The Mulatto":

In the nineteenth century the miscegenated "oedipal drama" of slavery described in Séjour's story was distinctly and explicitly associated with the Haitian Revolution. In fact, the idea that miscegenation might make "black" sons want to kill their white fathers constitutes one of the primary metaphors of the Haitian Revolution in the nineteenth century (Daut 5)

In his study of métissage, Roger Toumson outlines a Freudian connection between the image of the father and the image of the slave master: "Les rapports qu'entretiennent "Maîtres et esclaves" correspondent, dans le tableau symptomatique de la névrose obsessionnelle que décrit Freud, aux rapports entre le père et l'enfant" (107). We can, therefore, establish the slave master as the symbolic father figure in the colonial family romance described by Garraway.

Despite her proposed colonial family romance and the clear Oedipal conflict it would establish if the mulatto offspring were male, Garraway herself seems to caution against too hasty a recourse to traditional oedipal analyses of texts that recount the Haitian revolution. In The Libertine Colony, Garraway notes that the notion of tracing an oedipal complex is problematic in a slave society because the family is often "cut through with racial and class antagonisms" (279). This point is well taken; the traditional Freudian 
concept of an oedipal triangle (one mother, one father and male child) is skewed because the traditional family structure has been destroyed by slavery. The child born within this system would not have likely witnessed the affection of a father towards the mother; in fact, white paternity of mulatto slaves was often denied under threat of violence. Miscegenation, though common, was generally regarded as shameful behavior on the part of the white colonizers. The libertine freedom of the slave master to father mulatto offspring created what Garraway has called a "shadow family," a family that did not restrain the sexual advances of the white male towards the mulatto female even if she were possibly his daughter, because societal rules of kinship did not apply to slaves. The colonial family romance that Garraway posits not only positions all free people of color as the master's bastards, but it also posits places all slaves as the master's property. Therefore, the oedipal conflict of le mulâtre with the white father includes seeing his mother as his father's property:

Just as the very principle of ownership of persons radically contradicted social meanings of self and personhood in white society, miscegenation under slavery allowed for the eruption of two parallel yet entirely conflicting sets of norms relating to desire and kinship. Whereas the master observed rules of kinship in his white family, in his mixedrace shadow family slavery promoted his treatment of all slave women as his property, irrespective of blood ties (Garraway 285)

I argue here that the concept of the colonial family romance that Garraway presents, despite her acknowledgment of its difficulties, is actually the key to establishing the aggressions of the mulatto son. The difficulty in establishing clear in establishing an oedipal connection is resolved by applying Orlando Patterson's model of slavery as social death, which argues that the institution of slavery requires that the slave inhabit a place of non-being, a denial of basic human rights that define social existence. This 
creates a three-tiered set of oedipal motivations that are unique to the male mulatto, three different sources of aggression of the mixed-race son towards either biological or symbolic white paternity. The first motivation explanation of oedipal aggression towards white paternity follows the typical Freudian model: the male mulatto wishes to remove the father and enjoy the affections of the mother. As we shall see in our literary analysis, the affections of le mulatre towards his mother more take the form of protection of his mother. The second source of oedipal aggression is associated with the social standing of the male mulatto's mother: he also desires to enact retributive justice against the father for the mother's descent into social death. The third source has to do with the male mulatto's sibling relationships: the male mulatto is driven by his desire to remove the white male from his position of patriarch in order to protect mulatto women, for in Garraway's conception of the colonial family romance the female mulattoes are the offspring of the white father and therefore the male mulatto's sisters, symbolically if not biologically. The exclusion of the black male from the colonial family romance is of crucial importance in Garraway's model; as the black male poses no threat to the father, the sole source of white anxiety from another masculine figure is le mulâtre:

The most significant challenge to the white father remains [ . . . ] the threat of revenge from the mulatto sons. They seek not to replace him in his position of patriarch with sexual rights over all women but rather to save their sister from his criminal desires. In so violently opposing the white father's willful evasion of the incest taboo, the rebellious sons and daughter affirm that taboo, and in so doing, make a symbolic declaration of belonging to the master's family (Garraway 287)

Therefore, the image of the mulatto son becomes a triple threat to the white father (the symbol of slavery) for not only does he compete with the father for the mother's 
affection (traditional Oedipal aggression) he also is motivated to avenge her for her social death at the hands of the white father. Furthermore, he is motivated to protect is mulatto sibling from his father's incestuous libertinage. Victor Séjour's short story Le Mulâtre is the perfect text to examine this hypothesis, as it requires an appreciation of the protagonist's maternal history.

A thorough analysis of the Oedipal images in Victor Séjour's short story must entail the time frame in which it was written and its audience. Juan Victor Séjour Marcourt Ferrand, himself a mulatto and a member of the mulatto elite ${ }^{25}$ from New Orleans, Louisiana, wrote this story in France in 1836, six years into the July Monarchy. The July Monarchy was characterized by very ambivalent convictions on slavery itself, but was committed to redefining the relationship between metropolitan France and the French colonies. One of the ways in which the Orleanist monarchy intended to enact this was with a closer regulation of les gens de couleur libres in the colonies. In the era of a monarchy torn between preserving the support of the landed slave-owning colonists and the abolitionist stances that the July Monarchy initially promised, Victor Séjour's story stands as a reminder of the terrors that came from the continued institution of slavery in Saint-Domingue; a revolution that was remembered in the July Monarchy as the rebellion of the mulatto class against the rule of France. Victor Séjour's mature writings reflected certain constant themes of nationalism and family; characteristics that were present in seed form in his short story Le Mulâtre. 


\section{Images of Oedipus: Victor Séjour's Le Mulâtre}

The first words the mulatto protagonist states, his very entrance into the text, express his desire to make the father pay for a wicked behavior and sets an opposition between the mulatto son and his biological father: “ . . . je pourrais du moins lui reprocher sa conduit infâme" (Séjour 3). An oedipal reading of this one line has several layers of meaning. Exactly what wicked behavior does the young George wish to make his father pay answer for? A traditional oedipal family pattern would suggest the following: sleeping with the mother and competing with the father for the mother's affection. However, the reality of colonial slavery and the protagonist's racial identity as a male mulatto adds more questions to those initially posed, and complicates the young protagonist's dilemma. The answer to these oedipal dilemmas lay not in George's history, but the history of his mother, the enslaved black woman who is given personhood due to the racial identity of her son.

The story begins with a description of a slave trading post. This is where Séjour introduces Laisa, an eighteen year old Senegalese woman of exceptional beauty who finds herself sold to the then twenty-two year old Alfred. Her descent into social death proceeds in almost step-wise fashion: Laisa is removed from her country and place of birth, humiliated sexually by the slave trader and then sold. As she is taken to Alfred's plantation, she is serendipitously re-united with her blood brother Jacques, the only other living relative who happens to be driving the wagon Laisa is riding. The son of their dead father Chambo, Jacques represents an alternate father figure for Laisa and source of family connection, a family connection which would upset the colonial family 
romance of the plantation system of slavery. Jacques and Laisa's joyful reunion and sibling embrace is witnessed by the overseer ${ }^{26}$ of Alfred's plantation who, mistaking sibling affection for physical attraction, mercilessly whips Laisa's brother. Whether or not Laisa's brother survived the beating is left unanswered in the text, but the cruel beating of Laisa's brother functions both to emasculate the image of African black masculinity and remove any other source of masculine affection or protection for Laisa. ${ }^{27}$ White male dominance is established as the law of Alfred's plantation, superseding any other manner of black familial order and subsequently placing Laisa firmly as the property of the white male.

Over the next year, Alfred fathers a child by Laisa and then, refusing to acknowledge the son as his, abandons both mother and child and assigns them the most decrepit cabin on his plantation. As Marlene Daut notes (24), Séjour's text places the sexual relationship of Alfred and Laisa in a kind of ambiguity: "she was almost raped." Séjour's unique turn of phrase (almost raped) doesn't imply seduction or consent on Laisa's part; it rather underscores her complete lack of agency. The system of slavery that denied Laisa personhood as a woman places her in a realm of non-being; she knew it pointless to resist the man whom she now belonged, and existed in a state of being where she was forced to choose between social death and physical existence, or social existence and physical death. Laisa's only recourse to protesting her treatment was the slightest hints at her disdain of her owner, which irritated Alfred: "Pendant près d'une année, elle partagea la couchée de son maître; mais déjà Alfred commencait à s'en lasser; il la trouva laide, froide, insolente (3). Alfred's heinous acts towards Laisa are compounded 
as Laisa gives birth to a son that she names Georges. Séjour casts the biological paternity of the son into slight ambiguity as well, establishing Alfred as most probably, but not certainly, the Georges's biological father; thereby creating a "shadow family" that exists biologically, but outside rules of kinship and lineage in the colonial family romance:

Alfred le méconnut, chassa la mère de sa présence, et la fit reléguer dans la plus mauvaise cabane de son habitation, quoique convaincu, autant qu'on peut l'être, qu'il était le père de cet enfant ("Le Mulâtre" Séjour 3, emphasis mine)

The word used to describe Laisa's rejection, chasser, implies that Laisa's ousting from Alfred's presence was forceful and violent, requiring Laisa to flee for her life and the life of her infant son. The reprehensible treatment of a young woman and her son establishes a reign of terror over Laisa that has replaced control by sexual domination:

By creating sexual relationships with slave women based upon terror and fear, Alfred attempts to ensure that any progeny that result from these relationships will share that same terror and thus reproduce the power structure of white dominance over black submission. (Daut 23)

Laisa's purchase as chattel property, alienation from any other familial connection and subsequent abandonment completes Laisa's descent into social death, which Pattern explains is the state necessary for slavery to exist in a society. De-socialized and depersonalized, she is simultaneously the object of her son Georges's oedipal affection as well as a "non-being." Appreciating Laisa in this manner completes the oedipal triangle regardless of the identity of the father, for even if the mulatto character Georges could resolve any oedipal aggressions by identifying with his biological father (an unlikely outcome across the divide of racial hierarchy), he still must avenge his mother's social 
death against the system of slavery which has denied her the social rights of personhood.

Georges's growth into manhood takes place in the presence of his mother, with whom he shares a double attachment as an enslaved male mulatto. Not only is Laisa Georges's sole source of parental affection and protection, but he shares his mother's social status through the law of partus sequitar ventrum, meaning the child of a female slave will also be enslaved. ${ }^{28}$ Georges's youth becomes increasingly oedipal as he tries to pierce the mystery of his father's death with the determination which Oedipus displayed before the Sphinx. Refusing to answer her son's question, Laisa assures Georges that the knowledge of his identity would result in his father's hatred of him, which was would be death for Georges:

In the plantation economy, Alfred represents father and master, and thus Laisa's threat is a real one to the simultaneous son and slave, who as a son submits to the authority of his father and as a slave submits to the authority of his master ... (Daut 23, 24)

Georges's growth into manhood is accompanied by the death of his mother and a hint of his father's identity. Laisa leaves Georges a deerskin pouch containing a portrait of his father, securing Georges's promise that he will not open it until his twenty-fifth birthday. Following his mother's physical death, Georges occupies a strange type of nonidentity in the text; he is both slave and son, both property and progeny. Even more curious is the deep affection Georges has for Alfred. Although a slave, Georges experiences an inexplicable deep emotional connection to Alfred. Georges exhibits a filial love for his master, despite the fact that Alfred treats Georges as being no better than a prize animal: 
Comme si la nature le poussait vers Alfred ; il l'aimait, autant que l'on puisse aimer un homme : tandis que celui-ci l'estimait, mais de cette estime que l'écuyer porte au plus beau et au plus vigoureux de ses coursiers ("Le Mulâtre" 4)

This identification with his master / father would resolve the oedipal conflict but for the fact that Georges doesn't know that Alfred is his father and Alfred refuses to recognize Georges as his biological son. Ana Brickhouse calls this state of non-identity a state of liminality unique to the mulatto:

As a mulatto in the French West Indies, Georges occupies a racial and cultural position of liminality, lying unstably between the 'most miserable shack' of the slave and the educated gentleman that Georges has the legal and social potential to become in later adulthood, if his paternity is acknowledged" (Transamerican Literary Relations, p. 117).

The identity of his father is what Georges wishes to know the most, posing an oedipal dilemma which must lead to confrontation between father and son; the alternate resolution of oedipal conflict being accepting and identifying with the father, impossibility when the young protagonist cannot identity with a person whose identity he does not know. The withheld paternal name causes Georges to stay in Séjour's fictional society as a non-person, and sets the stage for Georges's hostility. Olympe de Gouges had called particular attention to the unwillingness of fathers to acknowledge their offspring of color as one of the conditions most likely to produce violence in the colonies. Her words, which closed out her writing of la Declaration des Droits de la Femme:

Ces Colons inhumains dissent; notre sang circule dans leurs veines, mais nous le répandrons tout, s'il le faut, pour assouvir notre cupidité ou notre aveugle ambition. C'est dans ces lieux, les plus près de la Nature, que le père méconnait le fils ... Que peut-on espérer de la résistance qu'on lui oppose ? la contraindre avec violence, c'est la rendre terrible, la laisser encore dans les fers, c'est acheminer de l'homme, la liberté, la loi seule a le droit de réprimer cette liberté, si elle dégénère en licence, mais elle doit être égale pour tous. (Gouges 112) 
Georges's liminality, other than his withheld paternal name and non-reciprocated love for Alfred, is seen in a very unique way: the complete lack of any identifying physical description. In this manner, Victor Séjour's portrayal of unresolved identity is quite remarkable; to write of a male mulatto in nineteenth century French literature with no physical description is so rare as to be almost unheard of. Romantic writers were typically fascinated with the physical description of le mulâtre and most often linked the physical traits of le mulâtre to the extent of his heroism or the depth of his depravity:

Quant à l'écrivain large d'esprit, il créera de préférence des Mulâtres héroïques, aux traits réguliers et à la peau très claire. Toute une série de ces héros ont tellement peu de sang noir dans les veines qu'ils passent pour des Blancs . . . La noirceur de l'épiderme reflet de la noirceur de l'âme est une ressource traditionnelle de la rhétorique raciste. Les écrivains qui ont créé des Mulâtres dont le léger bronzage ou la pâleur du teint annoncent toutes sortes de vertus ont inconsciemment sacrifie au même préjugé : simplement, au lieu d'insister sur la nocivité du sang noir, ils ont souligné que la valeur rédemptrice du sang blanc (surtout lorsqu'il prédomine largement) en neutralise l'action délétère. La différence entre les deux points de vue ne porte pas sur l'essentiel (Hoffman 232)

The lack of any identifying physique casts Georges's character in a state of complete liminality. This results in a lack of identity that will only be resolved by the father who, following the death of Georges's mother, is the only one who can solve the riddle of Georges's parentage.

Georges's complete devotion to Alfred is proven as Georges places his own life in jeopardy to save his master / father from an attempt on Alfred's life. Georges's mysterious knowledge of the assassination attempt and cryptic pleas to get his master to follow him to safety trigger Alfred's mistrust. Alfred flees the house, leaving his slave 
/ son to face the three would-be assassins single-handedly. Georges's brave fight against the three brigands leaves him wounded, and Alfred has him taken to his cabin and trented by his physician. During the twelve days during which Georges hung between life and death, Alfred's repeated visits resulted in an attraction to Georges's young wife Zélie, ${ }^{29}$ herself a mulâtresse and therefore Georges's symbolic (and due to the miscegenated history of colonial slavery, possibly his biological) sister. Alfred's repeated advances are rebuffed, and Zélie eventually injures Alfred in the course of defending herself. Insulted to be rejected and overpowered by une esclave mulâtresse, Alfred orders Zélie's execution and motivates Georges to avenge her life.

Denied identity by his father, Georges will realize identity, as Nancy Bentley has shown, by enacting revenge on the man who transgressed Georges's right to protect his wife from sexual assault and save his symbolic sister from a wrongful death. The man responsible for these heinous actions is, though not yet known to Georges, also the man who condemned his mother to social death. Georges leaves Alfred's presence and, taking his infant son, seeks refuge among the négre-marrons, a group of fugitive slaves. His greeting to the leader of the fugitive slaves "Afrique et liberté," once again suggests a son's affection for his deceased mother who was a native of Senegal. Georges's familiarity with the hiding place of the fugitive slaves also seems to resolve the mysterious knowledge of the assassination plot against Alfred, a man to whom Georges was completely devoted until Alfred's lecherous advances towards his wife. Georges now swears allegiance to the fugitive slaves, and Georges's emergence as his father's 
enemy is mirrored in the text as the rising sun (son) that silhouettes the gruesome hanging of his young wife. Georges now identifies as Alfred's enemy:

Ainsi cette femme pour avoir été trop vertueuse est morte du supplice des infâmes; croyez-vous que ce seul fait ne suffit pas à rendre l'homme le plus doux, méchant et sanguinaire ? ("Le Mulatre" 8)

Georges waits three years and, with the assistance of Alfred's other slaves, returns to Alfred's plantation. Georges's arrival finds him face to face with Alfred's acknowledged Oedipal Triangle, governed by the societal rules of kinship. Georges, the result of Alfred's shadow family, enters Alfred's home which now includes a wife and an infant son. Before enacting a physical revenge, Georges destroys Alfred's family, making Alfred beg for the life of his wife as George begged for the life of Zélie. Again, this action has been traced to on oedipal conflict resulting from the violation of George's identity: "the violation of identity caused by miscegenation" exacerbates a desire for patricide in the son, who seeks to dismantle the alliance between father as lawmaker and ruler ... by transforming him into the vulnerable, victimized role that the mother and son once occupied (Hathaway 154, 165)

Having poisoned Alfred's wife, Georges confronts Alfred and forces him to listen to his wife's cries for help as he Georges holds before Alfred's eyes the antidote that would save her life. Georges's vengeful bloodlust is stopped only momentarily by the suggestion that Alfred holds the mystery that Georges has searched for his entire life, the identity of his father and, consequently, his Georges's own identity. Georges's hateful, crazed banter, marked with the familiar personal pronoun $t u$, is replaced with the respectful vous as he tearfully almost begs Alfred to reveal the mystery of his identity: 
À ce mot la colère de Georges tomba, - Mon père ... mon père, dit le mulâtre la larme à l'œil, vous le connaissez ... oh ! dites-moi son nom . . . je vous bénirai . . . je vous pardonnerai.

Et le mulâtre était prêt à se mettre à genoux devant son maitre. Mais tout à coup des cris aigus se font entendre...

- Juste ciel . . . c'est la voix de ma femme, s'écria Alfred en s'élançant du côté d'où partaient les cris ...

- Comme rappelé à lui-même, le mulâtre se souvint qu'il était venu chez son maitre, non pour savoir le nom de son père, mais pour lui demander compte du sang de sa femme. ("Le Mulâtre" 10)

Alfred's insistence on his responsibility of his recognized fatherhood taking precedence over Georges's tearful pleas brings Georges back to his mission of retributive justice, and he restrains Alfred until Alfred's wife dies. Having enacted his vengeance for the murder of his own wife, Georges lifts an axe and decapitates his former master. As Alfred's severed head rolls on the ground, George hears Alfred finally acknowledge that he is George's father. Opening the satchel that contains his father's portrait, George realizes that his efforts for revenge have ended in the bloody slaughter of his own father, and George kills himself. The issue of liminality, again symbolized by a rising sun, shows the body of the white master / father lying next to the mulatto slave / son. The dénouement of Séjour's portrayal of le mulâtre tragique leads to a senseless death that both shocks and touches the reading audience:

It is precisely this desire for and fulfillment of bloody revenge, generating simultaneous sympathy and outrage in the reader, that makes up the core of the powerful image of the tragic mulatto. Séjour's mixed-race character Georges embodies the image of the revengeful, mixed-race son/slave who, motivated by an intense desire for revenge, becomes wholly tragic. What makes Georges tragic rather than purely despicable is that he does not set out to kill his own father, but rather becomes unwittingly entangled in the web of secrecy and lies that form the epicenter of slavery's miscegenated histories. (Daut 12) 
The other text I will examine in this chapter is Victor Hugo's Bug-Jargal, a historical novel recounting the terrors of the Saint-Domingue revolution. Whereas the similar images of parricide will occur in Hugo's novel, I argue that the Oedipal images that constitute historical memory of the Saint-Domingue revolution are accompanied by another image of familial turmoil, fratricide represented by the image of Cain.

Originally a short story written in 1819 and published anonymously in Conservateur Litteraire, Bug-Jargal was novelized as a historical romance by a very young, staunchly royalist Victor Hugo in 1826. Hugo's novelized account of the Saint-Domingue revolution differed from his short story in more than length; the name of the French narrator was changed from Captain Delmar to Léopold d'Auverney, and the character Marie d'Auverney was introduced as Léopold d'Auverney's finance and first cousin. Most significant to this dissertation was the introduction of the mulatto (all of them male) as the archetypal villain. The male mulatto was a character that Hugo did not include in his original story; le mulâtre as a character was added to Bug-Jargal after Hugo read several of the captivity narratives of French military officers who survived the Saint Domingue uprising. Hugo's representation of le mulâtre and his portrayal the liminality ${ }^{30}$ of $l e$ mulâtre in this historical romance offers, I argue, valuable insight into the representation of the mulatto population in the French imagination at a time when France had only recently recognized the independence of Saint-Domingue and the sovereignty of Haiti. To the romantic commonplace of Oedipus, Hugo revitalizes the eighteenth century image of Cain and adds the idea of fratricide. 


\section{Images of Cain: Victor Hugo's Bug-Jargal}

According to Roger Toumson in his seminal work Mythologie du métissage, the image of le métis has several different family paradigms, one of them being the image of Cain. The image of Cain itself actually predates the Oedipal images I have examined thus far in this chapter; the image of Oedipus came into vogue in the late eighteenth century and, as a symbol of the displaced father, appears often in Romantic literature. The figure of Cain, the image of primal murder and the crime of fratricide, came into vogue in the baroque era of the seventeenth century and reached great popularity during the Enlightenment:

Au XVIle siècle, tirant profit des bonnes fortunes du baroque, la représentation [de] Caïn devient le prototype du premier tyran auquel s'oppose le premier martyr, Abel. La laïcisation du personnage s'accélère au XVIII siècle et se parachève au XIXe siècle, avec le romanticisme ... Au schème du fratricide se superpose le schème du parricide. La «révolte contre le père» l'emporte sur le conflit fratricide (Toumson 138)

The image of Cain as a branded or marked assassin also has, Roger Toumson notes, a particular interpretation in the colonial discourse of slavery:

La symbolique du mythe de Caïn s'est prêtée, dans le discours colonial, aux variations les plus significatives, la marque du fer chauffée au rouge étant l'indice de la double malédiction métaphysique et historique qui frappe l'esclave "noir", "bossale", comme l'esclave de "couleur", mulâtre ou "zambo". (Toumson 136)

I will argue in the remainder of this chapter that Victor Hugo, with his novel Bug-Jargal, employs certain images of oedipal drama to pit images of white paternity against images of le mulâtre tragique. However, the most detailed acts of violence which result in the death are the acts of the deformed Spanish mulatto dwarf Habibrah. I argue that with Bug-Jargal, Hugo presents the image of parricide against the father figure of French 
colonial slavery, but represents the Saint-Domingue revolution as a site of another along with another, Biblical image of familial strife: fratricide.

As I have explained in Chapter Three, the narrator of the text is Léopold d'Auverney, a captain in the French colonial army who decides to entertain his military comrades with the story of his friendship with one of the slain leaders of the Saint-Domingue uprising, the African slave Bug-Jargal. The character of d'Auverney is a mixture of the military man of action and the introspective, solitary thinker:

Toujours le premier à cheval et le cornier sous la tente, il semblait chercher dans les fatigues corporelles une distraction à ses pensées. Ces pensées, qui avaient gravé leur triste sévérité dans les rides précoces de son front, n'étaient pas de celles dont on se débarrasse en les communicant, ni de celles qui dans une conversation frivole, se mêlent volontiers aux idées d'autrui. . . il était jeune. On lui eut donné trente ans, il était loin encore de les avoir (Bug-Jargal 31, 32)

Léopold d'Auverney is not a paternal figure in the text; that role is occupied by his paternal uncle, a very wealthy plantation owner in Saint-Domingue. D'Auverney is sent from France to live with his uncle with the intention of eventually marrying Marie, his uncle's daughter and therefore his first cousin. Léopold d'Auverney describes his uncle as a despotic slave-owner whose cruelty towards his slaves was only exacerbated by the intervention of his family:

Mon oncle était du nombre, heureusement assez restreint, de ces planteurs dont une longue habitude de despotisme absolu avait endurci le cœur. Accoutumé à se voir obéi au premier coup d'œil, la moindre hésitation de la part d'un esclave était punie des plus mauvais traitements, et souvent l'intercession de ses enfants ne servait qu'à accroitre sa colère. Nous étions donc le plus souvent obligés de nous borner à soulager en secret des maux que nous ne pouvions pas prévenir (Bug-Jargal 37, italics mine)

The above text, along with the physical and emotional descriptions of d'Auverney as a melancholic and pensive young man, establishes him as the mal du siècle hero who, 
according to Margaret Waller, is "a fiction of impotence." (Waller 14) Rich, young, and most of all French, Léopold d'Auverney is the quintessential romantic hero, a young man devoid of a true father figure and a victim of great loss.

Hugo's text places this archetypal Romantic hero in two types of sibling relationships, both of them characteristic of Romanticism. The first sibling relationship is one of incest, as Léopold d'Auverney is promised to marry a woman who is his biological cousin and, symbolically, his sister. The other relationship is a fraternal relationship that he shares with both the other inhabitants and the slaves of his uncle's plantation. As we have noticed from Roger Toumson's work, the relationship of a master to his slaves is portrayed as the relationship of a father to his children (Toumson 107). Most of the slaves seem to find favor in d'Auverney's, who pities their difficult lives. There is one particular slave however, a mulatto named Habibrah, whom d'Auverney finds extremely disagreeable. This slave, a mulatto categorized as un griffe, is distinguished from the other slaves by the special position he seems to have found with d'Auverney's uncle and his physical appearance:

Entre tous ces esclaves, un seul avait trouvé grâce devant mon oncle. C'était un nain espagnol, griffe de couleur, qui lui avait été donne comme un sapajou par lord Effingham, gouverneur de la Jamaïque ... Le griffe Habibrah (c'était son nom) était un de ces êtres dont la conformation physique est si étrange qu'ils paraitraient des monstres, s'ils ne faisaient pas rire. Ce nain hideux était gros, court, ventru, et se mouvait avec une rapidité singulière sur deux jambes prèles et fluettes, qui, lorsqu'il s'asseyait se repliaient sous lui comme les bras d'une araignée ... Mon oncle l'aimait à cause de sa difformité rare et de sa gaieté inaltérable. Habibrah était son favori. (BugJargal 39)

The fact that all of the villains in Bug-Jargal are mulatto makes mixed-race anxieties a given in the text. The mixture of white and black blood seems to result in untrustworthy 
individuals at best ${ }^{31}$, devious and depraved characters at worst. Habibrah's character also evokes a type of phenotypical anxiety; he has an appearance that is almost inhuman. This description is all the more remarkable considering that the category of griffe is, according to Moreau de St Méry's ethonography that supposedly informs Hugo's novel, one of the more attractive categories of mulatto: "[the griffe] is so favored by nature it is very rare to see one that does not have an agreeable countenance and pleasing features as a whole." (Déscription p 80) It seems that Habibrah is too servile and excessive in his actions for d'Auverney's uncle:

Je n'aimais pas cet esclave. Il y avait quelque chose de trop rampant dans sa servilité ; et si l'esclavage ne déshonore pas, la domesticité avilit. J'éprouvais un sentiment de pitié bienveillante pour ces malheureux nègres que je voyais travailler tout le jour sans que presque aucun vêtement cachât leur chaine ; mais ce baladin difforme, cet esclave fainéant, avec ses ridicules habits barioles de galons et semés de grelots, ne m'inspirait que du mépris. (Bug-Jargal 40)

The above text connects d'Auverney's dislike for Habibrah not only to Habibrah's excessive servile nature, but also with his excessive, gaudy clothing. As Garraway notes in The Libertine Colony, slaves were not allowed to wear any type of finery (137). This, along with the special position that Habibrah seems to enjoy, places Habibrah is the position of a favored "colonial child" of d'Auverney's uncle, and introduces what I suggest can be read as a type of sibling rivalry between d'Auverney and Habibrah. Hugo emphasizes this rivalry when d'Auverney's cousin and fiancée Marie is serenaded in Spanish by Bug-Jargal, who identifies himself as an African prince. As d'Auverney listens in mute rage, Bug-Jargal sings of conceiving a future with Marie: "Tu es blanche, et je suis noir; mais le jour a besoin de s'unir à la nuit pour enfanter l'aurore et le couchant, qui sont plus beaux que lui!" (52). As if to give physical form to the horrible thoughts 
that enrage d'Auverney at the thought of a black rival for Marie's affections, Habibrah suddenly appears at his side. The dwarf, knowing that d'Auverney is clearly outraged by the Spanish serenade by a black prince, taunts d'Auverney by responding in a mixture of Spanish and French, remarking that Spanish language brings back cherished memories of when he was a child and not a dwarf or a fool (54). Knowing that the idea of a black slave in love with Marie d'Auverney was enraging his master, Habibrah offers to identify the unknown singer for a price of ten bolsas. After taking the money, Habibrah again taunts d'Auverney with the idea of miscegenation, laughingly stating that the singer must be a fool to state that a mixed-race child such as Habibrah would be more beautiful than Léopold d'Auverney. Habibrah's short monologue emphasizes the idea of the union between black and white:

Or, si cette chanson dit vrai, le griffe Habibrah, votre humble esclave, né d'une négresse et d'un blanc, est plus beau que vous, señorito de amor. Je suis le produit de l'union du jour et de la nuit, je suis l'aurore ou le couchant dont parle la chanson espagnole, et vous n'êtes que le jour. Donc je suis plus beau que vous, si usted quiere, plus beau qu'un blanc (Bug-Jargal 55)

In identifying himself as the union of night and day, Habibrah identifies himself as an embodiment of the idea of black and white métissage, a concept that enrages d'Auverney. This type of taunting, mocking and contemptuous relationship exists between d'Auverney and Habibrah until the night of the Saint-Domingue uprising. This night is also the night of Léopold and Marie's wedding, the very night when Habibrah and d'Auverney's fraternal relationship becomes even more concrete as Habibrah's "colonial father" in the colonial romance becomes d'Auverney's father in law. Summoned from his marriage chambers to help put down the rebellion, Capitan 
Léopold d'Auverney discovers that his uncle's home has been overrun by slave rebels

and his uncle has been murdered in his sleep. The scene of his uncle's room changes his

opinion of Habibrah, who he has assumed has died trying to defend his uncle:

Mon malheureux oncle était là, gisant sur son lit ensanglanté, un poignard profondément enfoncé dans le cœur. Au calme de sa figure, on voyait qu'il avait été frappe dans le sommeil. La couche du nain Habibrah, qui dormait habituellement à ses pieds, était aussi tachée de sang, et les mêmes souillures se faisaient remarquer sur la veste chamarrée du pauvre fou, jetée à terre à quelques pas du lit. Je ne doutai pas que le bouffon ne fut mort victime de son attachement connu pour mon oncle, et n'eut été massacré par ses camarades, peut-être en défendant son maitre. Je me reprochai amèrement ces préventions qui m'avaient fait porter de si faux jugements sur Habibrah ... je mêlai aux larmes que $m$ 'arracha la fin prématurée de mon oncle quelques regrets pour son fou. D'après mes ordres, on rechercha son corps, mais en vain. Je supposai que les nègres avaient emporté et jeté le nain dans les flammes; et j'ordonnai que, dans le service funèbre de mon beau-père, des prières fussent dites pour le repos de l'âme du fidèle Habibrah (Bug-Jargal 94)

The slave uprising continues, with the eventual capture of Captain d'Auverney. Held prisoner in the camp of rebel slaves, d'Auverney is witness to the inner workings of the slave rebellion, led by the terrifying mulatto Biassou. ${ }^{32}$ In a strange type of address to the rebel slaves, Biassou urges the slaves to merciless killing of their former masters, having a special address to the mulattoes in the ranks:

Noirs créoles et congos, ajouta Biassou, vengeance et liberté! Sang-mêlés, ne vous laissez pas attiédir par les séductions de los diabolos blancos. Vos pères sont dans leurs rangs, mais vos mères sont dans les nôtres. (Bug-Jargal 126)

In this monologue, the character of Biassou establishes an Oedipal Triangle based on slavery, the white master as father, the black woman as mother, and the mixed-raced son. Having displayed filial affection towards the black maternal figures in the rebel camp by placing them under the protection of the rebel mulatto sons, Biassou now 
addresses the collective body of mixed-raced sons in the rebellion who are the products of the Saint-Domingue "shadow family":

Au reste, o hermanos de mi alma, ils ne vous ont jamais traités en pères, mais bien en maîtres; vous étiez esclaves comme les noirs. Pendant qu'un misérable pagne couvrait à peine vos flancs brulés par le soleil, vos barbares pères se pavanaient sous de buenos sombreros, et portaient des vestes de nankin les jours de travail . . (Bug-Jargal 126)

Biassou doesn't deny the white biological paternity of the mulatto men among his ranks, but rather uses the lack of white paternal affection and recognition of the mulatto sons to incite the revenge of the mulatto rebels. Biassou has gruesome instructions to those rebels in his army who may by chance find themselves face to face with their fathers during the massacres:

Maudissez ces êtres dénaturés! Mais, comme les saints commandements du bon Giu le défendant, ne frappez pas vous-même votre propre père. Si vous le rencontrez dans les rangs ennemis, qui vous empêche, amigos, de vous dire l'un à l'autre: Touyé papa moé, ma touyé quena toué! ${ }^{33}$ (Bug-Jargal 126)

I argue that in the above text Hugo, at the time a young royalist under the Bourbon Restoration, makes a very subtle suggestion to the resemblance of the Saint-Domingue Revolution to the French Revolution. Both uprisings required the killing of the symbolic father figure. However, the Saint-Domingue revolution, more bloody and barbaric than the French revolution in the French metropolitan imagination, called for a specific type of parricide: that of the biological as well as the symbolic father. Again, the complex web of the "shadow family" transforms the role of le mulâtre in the Saint-Domingue uprising into an almost completely oedipal drama, either symbolic or literal:

Since the plantation system was characterized by hidden and often-denied webs of kinship between white-father-masters and their mixed-race slave children, these secret webs of filiation meant that in the revolutionary hour a father could be mistaken for a master and vice-versa. (Daut 13, 14) 
Léopold d'Auverney's recollection of these bizarre events culminates in his sentence of execution. D'Auverney is led, bound, by a contingent of black (not mulatto) former slaves under the command of a short, hooded figure in a long march that leads to a deep pit next to a waterfall. The short, hooded figure announces d'Auverney's impeding execution, taking great pleasure in mocking d'Auverney and savoring the chance to kill him. Despite his fear, d'Auverney seems to recall having heard the voice of the hooded figure. When d'Auverney asks the short figure to identify himself, the enigmatic figure doesn't take off his hood but rather bares his chest, showing the names of two of his former masters branded on his leathery skin:

Je me penchai jusqu'à lui. Deux noms étaient gravés sur le sein velu de l'obi en lettres blanchâtres, traces hideuses et ineffaçables qu'imprimait un fer ardent sur la poitrine des esclaves. L'un de ces noms était Effingham, l'autre était celui de mon oncle, le mien, d'Auverney! Je demeurai muet de surprise (Bug-Jargal 220)

The name d'Auverney places the hooded slave in the household as Léopold d'Auverney. The image of the shared last name and the brand on the figures' skin evokes the image of Cain (the marked brother) and, therefore, Habibrah's desire to kill d'Auverney becomes a desire for fratricide. Finally realizing that the hooded figure must be Habibrah, d'Auverney watches Habibrah remove his hood and confess that he is the assassin of d'Auverney's uncle. In an obviously oedipal image on the night of the slave uprising, Habibrah left the child's bed and stabbed his master while his master slept. D'Auverney listens as the mulatto dwarf explains murder of his former master, a murder more motivated by the personal humiliation of being his master's buffoon and pet than the actual humiliation and social death of slavery: 
Je m'en suis vengé sur lui, je vais m'en venger sur toi ! Écoute. Crois-tu donc que pour être mulâtre, nain et difforme, je ne sois pas homme ? Ah! J'ai une âme, et une âme plus profonde et plus forte que celle dont je vais délivrer ton corps de jeune fille. J'ai été donné à ton oncle comme un sapajou. Je servais à ses plaisirs, j'amusais ses mépris. II m'aimait, dis-tu; j'avais une place dans son cœur; oui, entre sa guenon et son perroquet. Je m'en suis choisi une autre avec mon poignard! (Bug-Jargal 221)

Habibrah's oedipal blood lust resulted in an inability to find any satisfaction in the coldblooded murder of his former master, who died too suddenly for Habibrah's satisfaction. If Habibrah's sense of personal worth could not be recognized with his master's life, he wanted it to be recognized in death. His hatred and murderous rage, however, frustrated his designs:

Mais j'étais trop impatient d'entendre son dernier râle, j'ai enfoncé trop vite le couteau : il est mort sans m'avoir reconnu, et ma fureur a trompé ma vengeance ! Cette fois, du moins, elle sera plus complète. Tu me vois bien, n'est-ce pas ? II est vrai que tu dois avoir peine à me reconnaitre dans le nouveau dans le nouveau jour qui me montre à toi ! Tu ne m'avais jamais vu que sous un air riant et joyeux : maintenant que rien n'interdit à mon âme de paraitre dans mes yeux, je ne dois plus me ressembler. Tu ne connaissais que mon masque : voici mon visage! (Bug-Jargal 222, 23)

Habibrah's constant call for recognition evokes Kleinberg's analysis of recognition as an essential portion of the quest for ontological significance. The above text problematizes Bongie's reading of Bug-Jargal as an "anti-mulatto novel" (Bongie's appendix to BugJargal 215) Although coupled with savagery and blood-lust, Victor Hugo gives a psychological depth to the suffering of le mulâtre that has not traditionally been observed in scholarship of this novel. Like Georges in Victor Séjour's Le Mulâtre, Habibrah's blood-lust, barely sated by the death of the paternal image of the slave master, must be read against the unimaginable emotional angst of a life of unrecognized humanity. Like the mulatto slave Georges, Habibrah was considered as nothing more than an animal in the house of his master. Like Georges, Habibrah will enjoy the words 
of his enemy as he asks his life to be spared because the enemy has loved ones who love him. Like George, Habibrah is a mulatto who will kill his symbolic father; however, the character of Habibrah will extend this trope of family blood lust beyond the desire to kill the father to include the killing of the white, French brother.

D'Auverney's impending death is halted by the arrival of Bug-Jargal, who, ignoring both the presence and authority of Habibrah, commands the black guards to untie the prisoner. The image of fraternity is suggested in this passage as Bug-Jargal constantly refers to the non-mulatto black guards as "frères." The prompt obedience of the black guards sends Habibrah into a rage, promising to use his power as obi to rain curses on the guards if they do not carry out his orders to kill d'Auverney. Bug-Jargal loses his authority as a rebel leader for only a brief moment in the face of the superstition of the black slaves; he immediately and definitively regains authority over the guards by evoking his authority as African royalty:

Il vivra! Je suis Bug-Jargal. Mon père était roi au pays de Kakongo, et rendait la justice sur le seuil de sa porte.

Les noirs s'étaient prosternés de nouveau.

Le chef poursuivit:

Frères! allez dire à Biassou de ne pas déployer sur la montagne le drapeau noir qui doit annoncer aux blancs la mort de ce captive; car ce captive a sauvé la vie à Bug-Jargal, et Bug-Jargal veut qu'il vive! (Bug-Jargal 227)

Securing d'Auverney's release from the contingent of guards, Bug-Jargal leaves the scene. Having rereated into the shadows with the guards, Habibrah seizes the opportunity of Bug-Jargal's departure to again attempt to kill d'Auverney with a dagger, recalling the parricidal murder of d'Auverney's uncle. The abrupt attack results in Habibrah stumbling into the nearby pit, managing to halt his descent by seizing the root 
of a huge tree. From this precarious position, the mulatto dwarf begs d'Auverney's assistance. The metaphorical root from which Habibrah hangs becomes a platform for him to appeal to the goodness of the white race and the bloodline that connects him and d'Auverney:

Maître! criait-il, maître! Ne vous en allez pas, de grâce! . . N'aurez-vous aucune pitié pour votre pauvre bouffon ? II est criminel ; mais ne lui prouverez-vous pas que les blancs valent mieux que les mulâtres, les maitres que les esclaves ? (Bug-Jargal 230)

No sooner than d'Auverney chooses to attempt to reach Habibrah than the treacherous dwarf attempts to pull his would-be rescuer into the pit with him, preferring to kill d'Auverney even if it means his own death: "Je sais que j'aurais pu me sauver avec toi, mais j'aime mieux que tu perisses avec moi. J'aime mieux ta mort que ma vie! Viens!" (232) D’Auverney cries to Bug-Jargal for help, hoping that he has not gone too far from the scene of planned execution. He again escapes death when Bug-Jargal, who hears his cries for help and sees his plight, sends his faithful dog Rask to hold on to d'Auverney as Habibrah loses his grip and falls into the pit.

In this rescue scene, Hugo cleverly figures two tropes of black masculinity - l'esclave royale and le mulâtre - and portrays the latter as a deranged assassin. Bug-Jargal, who as an enslaved prince has at least as much reason to murder as Habibrah, is portrayed as a humane and courageous leader. D’Auverney embraces Bug-Jargal and thanks him profusely for his rescue. Bug-Jargal also tells him that he has also saved the life of his bride Marie, whom Bug-Jargal refers to as "ma soeur," and tells d'Auverney where to find her. D'Auverney's gratitude finds a deeply emotional expression:

Il me tendit la main et ajouta:

Frère, es-tu content ? 
Je le serra de nouveau dans mes bras, je le conjurai de ne plus me quitter, de rester avec moi parmi les blancs; je lui promis un grade dans l'armée coloniale. II m'interrompit d'un air farouche.

Frère, est-ce que je te propose de t'enrôler parmi les miens ?

Je gardai le silence, je sentais mon tort. (Bug-Jargal 235 - 236)

The idea of brotherhood or fraternity between different races is seen as a possibility, but only between the pure-blooded African prince and the white French romantic hero. The two tropes here are transcendent characters, Léopold d'Auverney much different from his cruel uncle, and Bug-Jargal and the pure-blooded black guards much less driven by revenge than the blood-thirsty mulatre. The liminality of le mulâtre twists his character to the extent where he is seen as a murderer of fathers and brothers ; as Roger Toumson states, "Le complexe de Cain et le complexe d'CEdipe en lui coincident." (Toumson 139). Bloodline fraternity between the races isn't seen as possible in Hugo's revised novel:

In Hugo's revision, the mulatto - embodied most spectacularly by Biassou and Habribrah - emerges as the place, the topos, where an anxiety about racial (in) differentiation can play itself out; sheer (African) blackness can, as a result, be treated more positively than before. (Bongie 252)

The analysis of these two works of French romantic fiction posits le mulâtre as the source of disruption in the colonial family romance. Whether portrayed as an image of Oedipus, who unknowingly kills his own father, or as an image of Cain who desires to kill his brother, le mulâtre who exhibits murderous tendencies is a tragic figure whose efforts to murder his brother or father lead to his death.

In each of these works, the character of le mulâtre tragique is motivated by either symbolic or biological patricide and / or fratricide. Le mulâtre romantique, on the other hand, seems to successfully negotiate a desired place in society and realize personal 
agency by resolving issues of identity, and either proudly acknowledging or accepting their mixed-race heritage. With this in mind, I suggest that the literary image of le mulâtre tragique and his frustrated attempts to achieve personal agency result from unresolved issues that were, ultimately, all in the family. The anxieties produced by the tragic mulatto in these two works of French Romantic fiction can be read the undesirable results of the existence of the male mulatto.

A conclusion of this discussion of Victor Séjour's and Victor Hugo's protagonists as tragic mulattoes must recognize the possible overuse, or possibly even misuse, of the term itself, which actually originates in American literary criticism. Sterling Brown coined the usage of the term tragic mulatto as a literary stereotype, usually a woman. The tragic mulatto was a character whose conflict was often believed to be biological, coming from the "warring blood in his veins" (Sollors 224). Victor Séjour's short story Le Mulâtre and Victor Hugo's Bug-Jargal both show the source of the mulatto's conflict to be social and psychological, not biological. The tragic end of le mulâtre tragique was completely avoidable in both Le Mulattre and Bug-Jargal. However, the death of both George and Habibrah were caused by the internal, complicated and miscegenated structures of the colonial family romance.

The use of the term "tragic mulatto" in critical literature seems to carry the sense of violent action, sentimentality, and denouement in an unhappy ending ... It is evocative of heavy emotions, tough confrontations between the recognizable forces of good and evil, innocence beleaguered by perfidious villainy, disastrous turns of the plot, the power of coincidence, and tears at the end. (Sollors 242, 243)

Although initially a product of American literary criticism, the image of the tragic mulatto, motivated to an oedipal aggression due to confront the father or a fraternal 
aggression to kill his brother, gives a very accurate model of literary representation in French romantic fiction for mixed-raced male character who failed to achieve a desired level of personal agency. 
Chapter Five: Alexandre Dumas and the Three Mulattoes: Le Mulâtre as Romantic Hero

In his seminal work on representations of blackness in French literature, LéonFrançois Hoffman says of the mulatto character in French romanticism : "Les personnages mulâtres les plus importants (dans ce sens que la trame d'un roman ou d'une pièce s'organise autour de leur aventure personnelle) sont des hommes libres devant la loi . . . à l'exception toutefois de ceux qui se révèlent être des "épaves" "(236). Hoffman's observation indicates that le mulâtre who is not enslaved or an épave (a former slave who could be sold into slavery) face other challenges in the French romantic imagination. As I have argued in Chapter Two, black masculinity was originally depicted in French literature in terms of exchange value and absence of agency. Therefore, a black male in the French literary imagination was either a slave, subject to slavery, or valued as having the worth of a slave.

The Saint-Domingue Revolution began to dissociate these two images (black masculinity and slavery) in the French Romantic imagination. As I have shown in the preceding chapter, memories of Saint-Domingue resulted in ghastly portrayals of $l e$ mulâtre during the 1820's. Under the more liberal leadership of Louis-Philipe and the triumph of romanticism in 1830, The black male proved to be an increasingly complex and interesting character to portray. If a romantic writer could not inscribe black masculinity within the image of slavery, how could he develop him as a character? In her book chapter "Georges, or the "Mixed-Blood Settles Scores," Claudie Bernard expands Hoffman's observation by explaining the socioeconomic realities of much of the French mulatto population: 
Individuals of mixed race could be both slaves and freemen. The latter, whether by birth or manumission (for services rendered or on account of clandestine lineage) had an ambiguous social situation .... Free "mulattoes" were dynamic demographically and active economically. They spoke the French of the elite class rather than vernacular Creole, practiced a Catholicism devoid of pagan influences, were indispensable to the defense of the colonies and looked upon as a rampart against the subjugated masses. Further, on occasion, they were themselves slave owners. Yet, they were perceived as a menace to the whites, and used as pawns by governors inclined to rule by division. (131)

A free mulatto in possession of the talent, internal reflection and complex personality that characterized the French Romantic hero provided a unique literary model for the romantic writer to explore. Unfortunately, such images were rare in metropolitan French literature during the 1800's. Alexandre Dumas, himself a Frenchman of biracial ancestry, provides three such mulatto characters in his historical novel Georges (1843). The development of the characters in Dumas's novel have been compared to the characters in other romantic novels, such as Stendhal's Le Rouge et Le Noir:

“George est [aussi] un roman d'éducation dont la problématique rappelle, quoique sur un mode imitative et dégradé confinant à la caricature, celle du roman stendhalien. Comme dans Le Rouge et le Noir, dont le récit récapitule partiellement la topique romanesque - le choix amoureux comme défi social, la pause réflexive de la prison, la marche à l'échafaud en tant que sacrement de l'individu d'exception - on y trouve I'histoire d'un jeune homme qui cherche le sens de son existence et l'affirmation de soi dans la lutte contre une société dégénérée, vide des valeurs authentiques - ou posées comme telles - dont il ressent en lui l'exigence." (Racault 191 - 192)

I explained in Chapter Two how the term mulâtre evolved from a very general, loosely defined biological category in the mid-eighteenth century to a highly complex system of racial categorization in the nineteenth century. France's costly and humiliating loss of Saint-Domingue and the steady rise of mixed-race elite in France's other colonies resulted in an uneasy interest in the mulatto population. This unease eventually found 
voice in French metropolitan literature, especially when wealthy biracial families began to enjoy increased prestige under the July Monarchy.

The 1830's and early 1840's not only marked the apogee of Romanticism, it also seemed to signal a shift in the way in which le mulâtre was depicted in French metropolitan literature. No longer limited to the deranged spectre of the Bourbon Restoration, le mulâtre could now take the literary trappings of the romantic hero (wanderlust, alienation, physical beauty, brooding genius, rebellious nature and contempt for society). I suggest that these romantic traits, when applied to the mixedrace male, could be studied as another literary categorization: le mulâtre romantique. Unlike le mulâtre tragique, whose quest for personal agency ends in Oedipal revolt and death, le mulâtre romantique seems to experience some measure of success in his quest for personal agency and the recognition of his humanity. As is the case with each mulatto character studied in this dissertation, le mulâtre romantique is inscribed into complete liminality. All of these traits take on a specific purpose in the literary representation of le mulâtre romantique, for the quest of le mulâtre romantique is to somehow identify and reconcile his particular liminality as he embarks on a quest for ontological significance. Alexandre Dumas gives us three examples of what I term le mulâtre romantique in his historical novel Georges (1843) with racial admixture and the familiar images of romanticism. Using the literary conventions of the traditional romantic hero as established by René de Chateaubriand and expanded by other romantic writers such as Stendhal and Honoré de Balzac, I argue that Dumas' representation of the three mulatto characters in Georges represent three possible 
avenues of personal agency for the wealthy, intelligent mulatto. Dumas portrays three specific types of romantic heroes: the rebel leader, the dandy and the trickster. The roles that these three mixed-race men assume in order to claim their place in the French colonies make le mulâtre romantique the principle character in a type of bildungsroman where le mulâtre learns how to deal with a French society who will respect his wealth and talent but still marginalize him for his race.

\section{Pierre Munier's Mal du Siècle, Le Mulâtre as the Rebel Leader}

In her groundbreaking study of masculinity and romanticism entitled The Male Malady: Fictions of Impotence in the French Romantic Novel, Margaret Waller examines le mal du siècle as a literary aesthetic introduced by René de Chateaubriand in 1802 with his novel René. Chateaubriand's depiction of his hero, in Waller's words, "became the avatars of melancholy, masculine genius for the Romantic generation ... This notion of literary genius as a solitary, melancholic and male has become synonymous with the Romantic writer and hero in most traditional literary histories and in the popular imagination." (9). This is an apt description of the first mulatto character that we encounter in Dumas' novel. In this section of Chapter Three, I will show how Pierre Munier, initially suffering from a mal quite similar to other romantic heroes, resolves his liminality and realizes a degree of personal agency. The manner in which he does this is reminiscent of romantic portrayals of Toussaint Louverture as a soldier and devoted father.

Pierre Munier is a wealthy, landed and slave-owning mulatto who makes his home on the beautiful French colony of Mauritius. Dumas introduces this father figure at a point 
of historical rebellion: I'lle de Bourbon is under attack from the British navy. A cultured man of remarkable military talent and loyalty to France, Pierre Munier comes voluntarily to defend his homeland. Pierre Munier is described in terms reminiscent of Moreau de Saint-Méry, displaying the importance of nineteenth-century mixed-race phenotypology:

L'homme était grand, maigre, d'une charpente tout osseuse, un peu courbé, non point par l'âge, puisque nous avons dit qu'il avait quarante-huit ans au plus, mais par I'humilité d'une position secondaire. En effet, à son teint cuivré, a ses cheveux légèrement crépus, on devait, au premier coup d'œil reconnaitre un de ces mulâtres auxquels, dans les colonies, la fortune, souvent énorme, à laquelle ils sont arrivés par leur industrie, ne fait point pardonner leur couleur. (Georges 53)

Pierre Munier is a brave, wealthy, middle-aged man driven by a fierce sense of French patriotism. However, his voluntary service to la guarde nationale is unceremoniously rebuffed by the other inhabitants of the island who, even in a time of national crisis, cry out "Pas de mulâtres! Pas de mulâtres!" Pierre Munier's efforts to join the military forces of I'lle de France were also refused by the primary antagonist, the battalion commander Malmédie (Georges 59). Despite this humiliating refusal, Pierre Munier proves himself superior to Malmédie by taking command of a regiment of black soldiers and heroically repelling the British naval advance. In the course of defending Mauritius, Pierre Munier saves the lives of his detractors and captures the enemy flag. Pierre Munier is again reduced to a murmuring child as Malmédie commands Pierre Munier to surrender the flag to him:

- Mais Monsieur, murmura Pierre Munier, c'est moi qui ai pris le drapeau aux Anglais.

- Je le sais bien, Monsieur ; mais il ne sera pas dit qu'un mulâtre aura impunément tenu tête à un homme comme moi. Donnez-moi ce drapeau.

- Cependant, Monsieur... 
- Je le veux, je l'ordonne; obéissez à votre officier.

- Pierre Munier eut bien l'idée de répondre; "Vous n'êtes pas mon officier, Monsieur, puisque vous n'avez pas voulu de moi pour votre soldat"; mais les paroles expirèrent sur ses lèvres; son humilité habituelle reprit le dessus sur son courage (Georges 72 - 73).

Pierre Munier's surrender of the British flag is a pivotal point in the text for all three male members of the Munier household. First, it launches Jacques and Georges Munier's individual ambitions to lead lives different from their father. It also is the catalyst that empowers them to do so, because after this heated exchange Pierre Munier decides to send his sons to France to protect them from the repercussions of defying the Malmédie family. For Pierre Munier, however, the surrender of the British flag symbolizes his personal surrender of his standing in the French colonies. Dumas explains Munier's conflicted actions as resulting from his marginal status in society:

Cela était incroyable, étrange, misérable, n'est-ce pas, de voir une nature d'homme si riche, si vigoureuse, si caractérisée, céder sans résistance à cette autre nature si vulgaire, si plate, si mesquine, si commune et si pauvre? Mais cela était ainsi ; et, ce qu'il y a de plus extraordinaire, c'est que cela n'étonna personne ; car, dans des circonstances, non pas semblables, mais équivalentes, cela arrivait tous les jours aux colonies; aussi, habitué dès son enfance à respecter les blancs comme des hommes d'une race supérieure, Pierre Munier s'était toute sa vie laissé écraser par cette aristocracie de couleur ... (Georges 73 emphasis mine)

Pierre Munier embodies an intersection of two literary images that were quite popular in the first decades of nineteenth century France; the romantic hero and the black male. ${ }^{34}$ The intersection of these two images requires a detailed examination of both, starting with the image of the early romantic hero.

Pierre Munier is in many ways the prototypic early romantic hero, who generally suffered from some vague psychological malady. Despite his wealth of personal talent and resources, the early Romantic hero usually struggled with internal contradictions. It 
is his internal battle that makes the Romantic hero interesting, for he is more than able to best his peers. In his book Sick Heroes: French Society and Literature in the Romantic Age 1750 - 1850, Alan Pasco offers a character sketch of the literary Romantic hero:

Though defeated, rejected, and impotent, literary Romantic heroes are usually portrayed as above the common herd, either because of their great intelligence, acute sensitivity, or heightened powers of insight or wisdom, and they are not at all adverse to being set off as an astonishing if not admirable spectacle (7)

Despite financial independence, unusual talent and resourcefulness, and a demonstrated military ability described in the text as "sublime" (Georges 65), Pierre Munier is also frustratingly indecisive, submissive to the point of humiliation, overly emotional and unable to claim his place in the social order. Instead of facing his detractors, Pierre Munier chooses a type of self-imposed exile:

... sa vie fut tout entière occupée à excuser sa naissance. Loin de briguer, malgré ses richesses et son intelligence, aucune fonction administrative, aucun emploi politique, il avait constamment cherché à se faire oublier en se perdant dans la foule ... (Georges 104)

After the conflict with the Malmédie family, Pierre Munier's paternal devotion towards his two sons turns into a maternal brooding and constant worry for their welfare. Margaret Waller's observation of the early romantic hero is consistent with the character of Pierre Munier: a mal du siècle protagonist with exceptional talent and rather feminized attributes:

The early Romantic hero ... is far more submissive than controlling, chooses to avoid society rather than swagger through it ... the mal du siècle protagonist demonstrates the passivity, sensitivity, and vulnerability associated with the era's idealized image of woman ... the mal du siècle represents, precisely, the hero's failure to be a "man," ... the protagonist's difficulty has to do with his inability to take up the traditional male role in a man's world. (11). 
Taking Waller's definition of le mal du siècle as an inability to assume a masculine role in society allows us to examine Pierre Munier's psyche. Margaret Waller calls the mal of the male romantic character a "fiction of impotence" (5). Racism has emasculated Pierre Munier, and every aspect of his life reflects this lack of masculine agency: "la meme pensée qui l’avait écarté de la vie publique le guidait dans la vie privée. Généreux et magnifique par nature, il tenait sa maison avec une simplicité toute monastique" (104). Avoidance of conflict, even with those who are clearly his intellectual and cultural inferiors, becomes his way of life. Rather than choosing a geographical exile however, as the traditional romantic hero does, Pierre Munier choses a social exile of "non-being." This defining attribute of his life defines in many ways his portrayal as a romantic hero. In James F Hamilton's article "The Anxious Hero in Chateaubriand's René," the mal that Chateaubriand sets into literary vogue is analyzed as a certain type of anxiety that is a result of radical societal change and "collapsing value systems and institutions which expose the individual to nothingness" (415). In her essay "Romantic Exile and the Melancholia of Identification," Kari Weil connects the melancholia characteristic of the Romantic hero with Freud's analysis of mourning, a reaction to the loss of a "fatherland, liberty, an ideal and so on" (Freud 243, emphasis mine). Pierre Munier's age, stated in the text as being in his mid- to late forties at the time of the British naval attack on l'lle de France (1810) would place the character's formative years as a young man at the intersection of pre-and post-revolutionary France. Pierre Munier's armement suggests a background of military service:

Il était vêtu avec une riche simplicité, tenait à la main une carabine damasquinée d'or, armée d'une baïonnette longue et effilée, et avait au côté un sabre de cuirassier, qui, 
grâce à sa haute taille, restait suspendu le long de sa cuisse comme une épée. (Georges 53)

These years of loyalty to France and military service, suggested by Pierre Munier's military experience, were a crucial place in history for France's wealthy mulatto population. The turmoil of the Revolutionary years, inspired by the Enlightenment ideals of universal man and fraternity, carried the promise of a life free from the daily subjugation of the colonial mulatto population. In true romantic tradition, the years that followed witnessed the death of that illusion. Nineteenth century French history placed the character of Pierre Munier at a cultural and historical crossroads; the SaintDomingue revolution ${ }^{35}$ had destroyed any trust that France's colonies may have had in the mulatto population, and the Mauritius of British racial assimilation is yet to come. Pierre Munier's state of deep disappointment with his present circumstances is typical of the early romantic hero, often a military figure who proved his loyalty to France only to find few opportunities to enjoy the glory for which they valiantly served.

The second examination of Pierre Munier that is central to our examination of this character as a romantic hero is as a black male. As I argued in Chapter Two, le mulatre is one of three basic tropes of black masculinity in the French literature of the eighteenth and nineteenth centuries, but the only one who does not repeat in some way the sentimental tropes of le bon nègre or l'esclave royale. These latter two tropes appear occasionally throughout the nineteenth century in works such as Victor Hugo's BugJargal (1826), Prosper Merimeé's well-known short story Tamango (1829), Eugene Sue's eponymous hero Altar Gull (1830), David, the brilliant ex-slave and medical doctor in Sue's Les Mysteres de Paris (1830) and Edouard Corbière's Le Negrier (1832). However, 
none of these characters offer the level of liminality incarnated by the trope of le mulâtre. The character of Pierre Munier is presented in a disturbing state of duality, simultaneously possessing potential for decisive, courageous action yet living in fearridden, self-imposed social exile. He also stands in a state of extreme liminality as a father: his devotion to his sons is divided between the pride of a father for his young courageous sons and a brooding type of worry more representative of maternal instinct. The mal of this character is caused by a racial alienation that doesn't allow the character to be definitively male. Therefore the mal du siècle of Pierre Munier's character can be seen, to borrow the title of Monique llboudo's novel, as le mal de peau. ${ }^{36}$ This mal is very similar to the mal du siècle caused by le vague de passions so characteristic of the traditional romantic hero. The difference between the black romantic hero and the more traditional romantic heroes is important to notice in the Romantic era, when the question of slavery, the loss of French colonial holdings and the gradual rise of scientific racism were starting to affect the French public at large. As Arthur Saint-Aubin states: "The question of the status and the role of black men within the body politic and within society at large subtends the collective consciousness of the period." (15). Le vague des passions is not a part of the black romantic hero's literary construction, for the mal of these characters have a specific source and can be named. ${ }^{37}$

In her article entitled "French Romantic Drama in Blackface, Le Doctor Noir", Barbara Cooper connects the mal of the Romantic hero to racial marginalization: "Race can read as another of the signs of marginality that often define and determine the destiny of the French Romantic hero" (77). The primary difference between the traditional romantic 
hero and the black romantic hero is that in the latter case, the $\mathrm{mal}$ is a marginalization based on skin color in a post-revolutionary republic. Herein lay the crucial difference between le mulâtre romantique and the other tropes of black masculinity in French romantic literature: whereas the black character in French literature is in Alexandre Kojève's words "sealed into thingness," and therefore has no possibility of ontological development or quest for individual meaning, the mal of le mulâtre involves a striking liminality which le mulâtre attempts in some way to resolve. Le mulâtre romantique resolves this liminality by separating himself from the black characters that surround him and engaging with those who would deny him his sense of personal agency by oppression based on his racial categorization as a mulatto. In the case of Pierre Munier, the liminality is resolved an interesting parallel with how the black masculine as a whole was constructed in the French nineteenth century literary imagination: actions that evoke the military and paternal images of Toussaint Louverture.

In his article "Isaac Louverture's Memoires: A Nineteenth-Century Representation of Black Masculinity in the Name of the Father," Arthur Saint-Aubin describes how Isaac Louverture's memoir entitled Memores d'Isaac, fils de Toussaint Louverture, sur l'expedition des Français sous le consultat de Bonaparte (1825) reflected and contributed to the construction of black masculinity in the early nineteenth century. According to Saint-Aubin, Isaac Louverture's memoires as well as the memoires of his famous father Toussaint Louverture are crucial to the understanding of black masculine agency and establish two important metaphors ${ }^{38}$ that are echoed in literature: military skill and the prison cell. In the case of Dumas's character Pierre Munier, the possibility of 
his son Georges being imprisoned moves him to resolve his troubling liminality as the prison cell represents slavery. Several years after Pierre Munier's humiliation at the hands of Monsieur Malmédie, Pierre Munier is described as an old man with two grown sons, both of whom in their own ways challenge "I'aristocracie de couleur" that has resulted in their father's mal. Georges Munier, an accomplished creole gentlemen turned leader of a slave revolt, has been seriously wounded and now is being chased by the colonists who wish to imprison and then execute him. The thought of the colonists relegating his son to a state of "non-being" by placing his youngest son in a prison cell (that being an echo of the institution of slavery) causes Pierre Munier to resolve his liminality. Suddenly, Pierre Munier becomes the man whom he has always shied away from being and welcomes confrontation with the white racists whom he calls "messieurs les blancs":

Le vieillard pâlit; puis on le vit frémir de tout son corps; il était évident qu'il se livrait en lui un combat terrible. Enfin, il releva le front, secoua la tête, et regardant le blessé :

-Te prendre! murmura-t-il ; te trancher la tête ! me prendre mon enfant, me le tuer ! Tuer mon George ! Et tous cela, parce qu'il est plus beau qu'eux, plus brave qu'eux, plus instruit qu'eux... Ah, qu'ils y viennent donc !

Et le vieillard, avec une énergie dont, cinq minutes auparavant, on l'aurait cru incapable, s'élança vers sa carabine suspendue à la muraille, et saisissant l'arme oisive depuis seize ans :

-Oui, oui ! qu'ils viennent ! s'écria-t-il, et nous verrons. Ah ! vous lui avez tout pris, messieurs les blancs, à ce pauvre mulâtre ; vous lui avez pris sa vie, qu'il n'eut rien dit encore ; mais vous voulez lui prendre son fils; vous voulez lui prendre son enfant pour l'emprisonner, pour le torturer, pour lui trancher la tête ! Oh ! venez, messieurs les blancs, et nous allons voir! Nous avons cinquante ans de haine entre nous; venez, venez, il est temps que nous fassions nos comptes.

- Bien, mon père, bien ! s'écria George en se relevant sur son coude et en regardant le vieillard d'un œil fiévreux ; bien ! Je vous reconnais. (Georges 357-358, emphasis mine) 
Pierre Munier's challenge of the system that threatens his son also resolves his liminality as a parent. For the majority of the text, Pierre Munier's inability to exert masculine prerogative and agency also has manifested itself as an inability to be a decisive masculine figure for his two sons. At the time of the British naval attack, it is George Munier who suggests that his father take command of the black regiment who were in need of a commander, and it was Jacques Munier who defended his younger brother George when attacked by Henri de Malmédie. In both of these instances, Pierre Munier's internalized inferiority renders him unable to take the traditional role of the father. George and Jacques' departure for France (leaving their father defenseless in an environment that the two sons seem much more equipped to handle) leaves Pierre Munier a lonely and rapidly aging man who doesn't recognize either of his sons when they return to him. George's announcement of his love for Sarah Malmédie garners the support of Jacques Munier, who believes that George is worthy of any woman he chooses. However, Pierre Munier is terrified that George's love of a white woman will have horrifying results (Georges 238). The character of Pierre Munier as a father, therefore, is established as a worrying, fearful aging man who seems to have little in common with his two adventurous sons. The manhunt for his youngest son resolves this parental liminality and motivates Pierre Munier to fight an unjust system of racial hierarchy. Pierre Munier joins the rebellion that his son Georges has started and leaves his plantation:

Il embrassa dans un coup d'œil ces riches plaines de cannes, de manioc, de mais, ces magnifiques bosquets de pamplemousses, de jamboses et de takamakas, ce splendide horizon de montagnes qui fermait son immense propriété comme une muraille gigantesque. Il pensa qu'il avait fallu trois générations d'hommes honnêtes comme lui, 
laborieux comme lui, estimés comme lui, pour faire de celui quartier le paradis de l'ile, poussa un soupir, essuya une larme ; puis, d'détournant les yeux et secouant la tête, il regarda, le sourire sur les lèvres, le brancard où l'attendait l'enfant blessé, pour lequel il abandonnait tout cela (Georges 359).

The devotion of Pierre Munier for his son (a devotion that results in decisive and militant action) evokes the second image of black masculinity inspired by the legend of Toussaint Louverture: the devoted father figure (Saint-Aubin 15). Among the final descriptions of Pierre Munier are those of an invisible presence protecting his sons as they engage another British naval attack. This image is quite the opposite of Pierre Munier needing his sons to direct and inspire him, Pierre Munier is now protecting his sons in the image of an ideal father and a man of military skill:

Les deux frères sont au plus pressés des rangs anglais, frappant et frappés, luttant de sang-froid, de force et de courage ; deux matelots anglais lèvent la hache sur la tête de Jacques; tous deux tombent frappés par des balles invisibles. Deux soldats de marine pressent Georges de leurs baïonnettes : tous deux tombent à ses pieds. C'est Pierre Munier qui veille sur ses fils; c'est la fidèle carabine qui fait son œuvre (Georges 449)

Pierre Munier's liminality is resolved in a type of romantic confession where he admits that there were indeed years of hate between him and "messieurs les blancs" and his challenge of the aristocracy of color results in the romantic hero embracing his true nature. In this way Pierre Munier fulfills the true role of the literary Romantic hero as described in James Hamilton's psychological study of le mal de René: “The hero's quest is not the objective one of adaptation but the subjective one of self-possession, the attainment of being and his true nature." (Hamilton 416) In the case of the mulatto who is also a romantic hero, the true self is one that presents the possibility of a reversal of society based on a racial binary, the figure of a mulatto who destabilizes early French society and represents "the melting of all that is solid into air." (Bongie 242) 
Pierre Munier presents the image of the dark-skinned rebel mulatto in Georges depictions of the early romantic hero; however, the lighter-skinned sons Georges and Jacques Munier display manners of engaging with the racial binary still in operation during the post-revolutionary France of the 1830's to the late 1840's. The characters of Georges and Jacques Munier are more duplicitous, more scheming than their father and display more of an ability to challenge society by social rebellion, deceit, trickery and masks. In the next section of this chapter, I will explore the character of George Munier and examine how the liminality of the eponymous hero is resolved by rebelling against society as a French dandy. By creating a character who refuses to deny his racial heritage, Dumas invents a character that is completely new to the literary tradition of metropolitan France: the mulatto dandy.

\section{Georges Munier: The Mulatto Dandy}

An examination of Georges Munier's character requires that we examine this term in the light of Toumson's definition of le mulâtre. The term mulâtre itself has a specific connotation in the nineteenth-century era of romanticism:

C'est à l'anthropologie romantique et non à l'anthropologie des Lumières qu'est due la nouvelle articulation des deux termes : un Mulâtre est un Nègre qui n'a pas la peau noire. (Toumson 95)

Phenotypically, the black male without black skin was inscribed socially within a racial minority and also able to transgress the limitations of minority status, especially when the person's biological heritage is unknown. Therefore, le mulâtre who is evokes phenotypical anxiety within a society that is based on a racial binary. This is not entirely the case with Pierre Munier, whose African features and therefore the clearly inscribe 
him within a biracial heritage. As Dumas' novel states, the character of Pierre Munier was not pardoned for his color, despite his great wealth (Georges 53). As I have argued in Chapter Two by examining Nancy Bentley's examination of the mulatto, le mulâtre in French romantic fiction closely resembles that of American antebellum fiction in that the body of le mulâtre becomes an important subtext. As the presence of African features deny Pierre Munier access to certain degrees of societal recognition, the absence of those African features on his sons' bodies create two different sources of anxiety in the novel. Firstly, the partial absence of African features in the Munier sons subtly suggests that their mother may have been either a mulâtresse or a white woman, both of whom were considered to be the property of white men. ${ }^{39}$ The second source of anxiety presented by the partial absence of African phenotype is that the Munier sons will have other options of resolving their liminality other than military rebellion; as "white" black men, they could be rebels against society and religious systems. In Georges, Alexandre Dumas creates a mulatto dandy who is both a social and metaphysical rebel.

Dumas' historical novel Georges was completed at a time in which the literary conventions of dandyisme were undergoing a profound change in French literature. A literary import from England, le dandy was characterized in the years between 1810 and 1830 as an effeminate, idle fop. An aristocrat by birth, le dandy could afford to be idle and therefore caught the attention of France during the Bourbon Restoration when the learned populations of France were eager to reassert trappings of aristocratic privilege. This literary image underwent significant changes after the French bourgeoisie came to 
prominence after 1830 . Aristocracy would, from the 1830 's onward, be characterized less by bloodline and more by wealth and merit. This change in French society resulted in a new kind of literary hero. France became fascinated with the literary hero who was exceptional, but not necessarily from noble birth (Moers 130). Certain aspects of $l e$ dandy remained; for example, le dandy was a superior person who saw himself as a man without peer. The new literary dandy redefined the notion of being déclassé, expanding it beyond mere biological lineage or social standing. As Domna C. Stanton notes in her work on dandyism entitled The Aristocrat as Art: A Study of the Honnête Homme and the Dandy in Seventeenth- and Nineteenth-Century French Literature, the dandy can even be a peasant. The conflict for le dandy is that he is completely convinced that there is no model for the kind of man he aspires to be, a conflict that Stanton defines as a kind of déclassement. This déclassement of le dandy situates him for reclassement, which he demands on his own terms. (Stanton 71).

This is an accurate portrayal of young Georges Munier, whose physical description is characteristic of several masculine figures in early French nineteenth century literature. Due to the radical upheavals, illnesses, military and political coups and exile that characterized the first half of this century, French writers were fond of portraying male characters that were far from robust (Pasco 32). At the same time, the emphasis on intellectual ability and ambition made the typical romantic male figure a person in possession of incredible intellectual insight and even cunning. This is the case with Dumas' description of Georges Munier. Alexandre Dumas emphasizes his small stature 
and places his unimpressive physical presence in contrast with his striking intelligence

and will-power:

. . . un enfant de douze ans a eu près, mais dont la nature grêle et chétive ne tenait en rien de la haute stature de son père, ni de la puissante organisation de son frère ... le petit Georges paraissait-il deux ans de moins qu'il n'avait réellement, tant, comme nous l'avons dit, sa taille exiguë, sa figure pale, maigre et mélancolique, ombragées par de longs cheveux noirs, avaient peu de cette force physique si commune aux colonies ; mais, en revanche, on lisait dans son regard inquiet et pénétrant une intelligence si ardente, et, sans le précoce froncement de sourcil qui lui était déjà habituel, une réflexion si virile et une volonté si tenace, que l'on s'étonnait de rencontrer à la fois dans le même individu tant de chétivité et tant de puissance. (Georges 54)

Unlike his father, Georges Munier's initial physical description is devoid of any African features. In contrast to the African mulatto phenotype and robust physical presence central to the character of Pierre Munier, Georges Munier's description closely resembles that of another literary dandy: Julien Sorel in Stendhal's Le Rouge et Le Noir:

C'était un petit jeune homme de dix-huit à dix-neuf ans, faible en apparence, avec les traits irréguliers, mais délicats, et un nez aquilin. De grands yeux noirs, qui, dans les moments tranquilles, annonçaient de la réflexion et du feu, étaient animés en cet instant de l'expression de la haine la plus féroce (Le Rouge et Le Noir 24)

Also very characteristic of the male romantic hero in the nineteenth century is a change in generational perspective from father to son. The characters of Georges Munier and Julien Sorel both have strained relationships with their fathers. Julien Sorel's relationship with his father requires that he submit to his father's physical abuse; Georges Munier's relationship with his father requires that he watch his father submit himself to societal abuse. Despite the tender relationship between his father and himself, Georges Munier is hard pressed to respect the man who allows himself to be subjugated by those who are not of his caliber. At the time of the naval attack, Georges Munier clearly sees the difference between his father and Monsieur Malmedie, and 
wonders why his father doesn't insist on the same respect as other men in his community:

N'ayant pas d'armes, il se tenait contre son père, et serrait de toute la force de sa petite main le canon de la belle carabine damasquinée, partant alternativement ses yeux vifs et investigateurs de son père au chef de bataillon, et se demandant sans doute intérieurement pourquoi son père, qui était deux fois riche, deux fois fort et deux fois adroit comme cet home, $\mathrm{n}^{\prime}$ avait pas aussi comme lui quelque signe honorifique, quelque distinction particulière (Georges 55)

Georges watches as his father is berated publicly by Monsieur de Malmedie. Unable to endure the public humiliation of his father, Georges tries to pull him away from his enemies with such force that Pierre Munier mistakes him for his older brother Jacques. Attempting to regain his father's dignity, Georges encourages his father to lead the black troops into battle against the British. The victory that his father wins over the British naval advance ends with young Georges holding the captured British flag which his father has won. This attracts the attention of Henri de Malmedie, Monsieur de Malmedie's son, who demands the flag from Georges. Georges refuses to surrender the flag, going so far as to push Henri de Malmedie. This results in the latter taking a sword and slicing Georges Munier on the forehead. In her book chapter entitled "White Negroes, Nothing More: The Ambiguous Role of the Mulatto in Alexandre Dumas' Georges," Molly Krueger-Enz comments on the significance of Georges Munier's wound: ... Henri pulls out his sword and slashes Georges' forehead so that the latter will always be reminded of the white's superiority and domination, and he leaves a scar that will forever brand Georges (Krueger-Enz 95)

The young Malmédie's wounding of the eponymous hero is a reference to the statute that a slave or a person of color was not allowed to harm a white person. This scar not only serves as a reminder of white superiority and domination, it is a subtle reference to 
Le Code Noir and the only reference to Le Code Noir inscribed on a black body that did not have black skin. Henri de Malmédie's words, more than his violent response, reveals the right by which he wounds the son of a wealthy landowner and courageous military leader without fear of reprisal: "Ah! mauvais mulâtre, tu oses me toucher? s'écria Henri. Eh bien, tu vas voir" (69). The scar that results from this altercation is the reminder of the negritude (Hoffman's term for blackness) of the Munier family on a body that, in childhood, did not display any characteristics of the mulatto phenotype.

This scar on Georges Munier's body sets him apart from other male mulattoes in the story and determines how he will resolve his liminal appearance (white or black) and standing in society (following the example of his father or choosing another path). The character of Georges Munier, at an incredibly young age, has a self-awareness that is characteristic of romantic heroes. In the exchange that marks Georges for life two groups of people become the "other." Of course, the white men who rule in the aristocracie de couleur become the other, having marked their perceived sense of superiority on the body of young Georges. However, certain mulatto individuals also become the other, such as Georges; own father. Georges determines he will not be like his father or the other mulattoes who allow themselves to be "marked" by the subtext of their bodies. The only lesson that Pierre Munier tries to teach his son is that the aristocracie de couleur must be respected:

Georges, qui, en voyant couler son sang, n'avait pas laissé échapper une seule larme, il éclata en sanglots dès qu'il se retrouva les mains vides en face de son père, qui le regardait tristement sans essayer même de le consoler. (Georges 73) 
In his article Self, Society, Value and the Romantic Hero, Frederick Garber states that awareness of the self also includes identification of "the other":

Accompanying this self-awareness and in part determining its degree is a concomitant sensitivity to the boundaries of self and non-self, boundaries to the distinction of which the hero devotes a good deal of energy, care and alertness (Garber 322)

Thus at a young age, Georges appreciates that he is different from the mulattoes that allow themselves to be disrespected by whites. Inexplicably, Georges has claimed a right of self-determination that he did not need to see modeled. Unlike his father, he will instigate a rebellion that is, at first, a social rebellion:

Georges, né dans les mêmes conditions que son père ... avait observé d'instinct la conduite de son père, dont il avait, tout jeune encore, pénétré les motifs ; or, l'orgueil viril qui bouillonnait dans la poitrine de cet enfant lui avait fait prendre en haine les blancs qui le méprisaient, et, en dédain, les mulâtres qui se laissaient mépriser. Aussi se résolut-il bien à suivre une conduite tout opposée à celle qu'avait tenue son père, et à marcher, quand la force lui serait venue, d'un pas ferme et hardi au-devant de ces absurdes oppressions de l'opinion, et si elles ne lui faisaient point place, a les prendre corps à corps comme Hercule Antée, et à les étouffer entre ses bras. Le jeune Annibal, excite par son père, avait juré haine éternelle à une nation ; le jeune Georges, malgré son père, jura guerre à mort à un préjugé (Georges 105 - 106).

The image of Georges Munier as a soldier is of particular importance in analyzing this character as a dandy. The literary representation of the dandy had continued to evolve during the course of the July Monarchy, gradually shedding the previous trappings of foppish behavior and inertia that was common during the anglomania of the Bourbon Restoration. By the middle of the 1840's the dandy had become the ideal social rebel, his representation culminating in 1845 in Jules Amédée Barbey d’Aurevilly's essay “Du Dandysme et de Georges Brumwell.." ${ }^{\prime 0}$ Alexandre Dumas' eponymous hero is a dandy in this changing, evolving literary tradition; a soldier at war against the prejudice against mulattos. From youth, Georges Munier is seen as engaged in a war to overcome the 
prejudice against mulattoes that defines his colonial world. As Stanton observes, military imagery makes up a significant part of the "constellation of signs" (45) that compose le dandy. Le dandy of the July Monarchy and subsequent years was actually a semantic field of literary signs that sets the rebel against society:

The quest for supremacy of the honnête homme and the dandy is inscribed in a language of military conquest, an extended vocabulary of domination and subjection that transforms society into a metaphorical battleground (Stanton $p$ 64)

Georges Munier's declaration of war may have started in Mauritius, but his training as a dandy takes place in metropolitan France. The battle against the British navy only delayed the eventual conquest of Mauritius by England. Under new colonial rule, Pierre Munier fears for the safety of his sons who have incurred the wrath of the Malmédie family. Georges Munier and his brother Jacques are sent to France to continue their education. Again, there are similarities between Georges Munier and other major male characters in French literature that represent the rebellion inherent in dandyism: Jacques and Georges flee the coup (like the provincials, Stendhal's Julien Sorel, Balzac's Eugène de Rastignac, and Flaubert's Fréderic Moreau) to pursue their education in Paris, where the prejudice of color is noted as being less virulent (Krueger-Enz 135)

In Paris, Georges finds himself tortured by his classmates because of his small stature. He is for a while protected by his older brother; however Jacques Munier eventually leaves Paris for a life at sea. It is at this point where Georges Munier's development into a dandy begins in earnest. Georges refuses to allow himself to be bullied, and earns the respect of his tormentors by fighting with them at every opportunity. He develops great skill at fencing, firearms, and equestrian. As he becomes a young man, he learns to accentuate his good looks and use his wealth and education to travel in the highest 
circles of Parisian society. Once again, the development of Georges Munier has been compared to the literary heroes of other nineteenth century works:

Racault posits that Georges's goal is to be recognized socially by the aristocracy of the Ile de France. The way he achieves this is by his fortune on the one hand, and his careful study of elegance, good manners, and how to emphasize his natural beauty on the other. This is typical of the Romantic Bildingsroman by Balzac or Stendhal, in which the protagonist takes on an aristocratic society with the goal of assimilating, all the while despising it (Kreuger-Enz 387)

These lessons are, for Georges Munier, only tools to develop an almost superhuman level of self-control. As Molly Kreuger-Enz wrties, Georges Munier is among the French characters who "take on an aristocratic society." He does this not to conquer France, but to return to Mauritius. His training in the conquest of France's colonial society includes goes to gambling halls simply to conquer his fear of gambling addiction, dating lovely women solely for the purpose of controlling "les sens ardents d'un homme des tropiques," (112), and participating in a pistol duel at a closer range than his opponent has ever seen. This sang-froid, more than any other skill Georges learns, completes his image as a dandy:

Dandyism is more than a cult or a literary pose. It is indeed a philosophy of life which has historical roots in society . . . the essence of dandyism, "le culte de soi-même," lies in the conflict of the superior man, the dandy, with society. He refuses to be constrained by the temporal laws of society, and he refuses to submit to the indignities of emotional involvement (Ross Ridges 60)

Having symbolically "conquered" France by mastering the social graces of the French elite, Georges travels abroad and becomes a man of the world. A year in London polishes his international reputation as a man of distinction, and service in the military gives Georges the opportunity to develop an unbelievable level of self-control. Finally Georges Munier returns to l'lle de France to confront the prejudice that has marked him 
both emotionally and physically. It is Georges' cold, calculating return to the site of his struggle, rather than completely escaping to an exotic or foreign locale, that expands his representation as a traditional romantic hero and inscribes him into the image of the dandy:

Dandies are heroes in an unheroic age, and see themselves as better than their surroundings and superior than their contemporaries. However, the dandy distinguishes himself from the romantic hero in that, rather than fleeing bourgeois society and finding refuse in nature, he hides his frustration behind an impenetrable mask or air of aloofness and seeks to dominate the society they despise. (Rossbach 83)

The domination of Mauritius that Georges Munier undertakes will lead him to rebel against the white plantocracy of the island and align himself with black slaves. His alignment with black slaves will fail as well, leading him to a place where he will rebel against religious systems and death.

Georges Munier returns to his homeland accompanied by Lord Williams Murrey, the British governor assigned to maintain peace on in the colony. The two quickly progress from being travel acquaintances to friends, and Georges Munier is invited to a ball as Lord Murrey's special guest. In the few days that transpire between Georges' return and Lord Murrey's ball, Georges re-enters the life of the Malmédie family by saving the life of Sarah Malmédie, the niece of Monsieur de Malmédie and Henri de Malmedie's financé. His cool-headed rescue of Sarah from a shark attack both brings Georges to Sarah's attention and places the Malmédie family in his debt. As a result, the two powerful planter families are once again in a situation of social rivalry.

It is at Lord Murrey's ball that Georges publically declares war on the racial prejudices that govern the island. Elegantly dressed, the eponymous hero arrives fashionably late 
to the event. His entrance is announced to great effect in the presence of all the assembled French and British aristocracy and officials:

La foudre, tombée au milieu de l'assemblée que nous venons de réunir sous les yeux du lecteur, n'eût certes pas produit plus d'effet que n'en produisit cette simple annonce. Chacun se retourna vers la porte à ce nom, se demandant quel était celui qui allait entrer ; car, quoique le nom fût bien connu à l'ile de France, celui qui le portait était depuis si longtemps éloigné, qu'on avait à peu près oublié qu'il existât. (Georges 189) Murrey's ball (indeed, the character of Lord Williams Murrey himself in Dumas' novel) symbolizes the effort of the British government to assuage the racial tensions that troubled Mauritius. Georges Munier cannot accomplish his personal mission to conquer racism while simultaneously cooperating with Murrey's political agenda. The public shock that accompanied Georges Munier's elegant and calculated entrance was the first step in a process by which Georges starts to avenge his family's indignities while simultaneously distancing himself from both the white French colonial planters and the British political environment:

The largely fictional corpus of dandyism includes a panorama of social classes in which the superior man can and must be set off from the mass. In this narrative space, the dandy's name signals his preeminence immediately both to the reader and to his fictional audience, insiders and outsiders alike. (Stanton 91)

Having entered the high society of Mauritius, Georges spends the night conquering that society with his wit, elegance and social grace. His education, military experience and social polish make him the center of attention at the ball. However, race still remains the deciding factor of social standing among the Malmédie family; Monsieur de Malmédie refuses to allow Georges to dance with his niece, Sarah Malmédie. The fact that Georges has saved her life only days before does nothing to change the opinion of 
the Malmédie family towards him. Georges's old rival does not fail to notice Georges's

behavior as an "act of war" on racist society, and Henri de Malmédie responds in kind:

Si Georges, de retour à l'ile de France, fut rentré humblement dans la condition, qu'aux yeux des blancs la nature lui avait faite, et se fut ainsi perdu dans l'obscurité de sa naissance, Henri ne l'eut point remarqué, ou, dans ce cas, ne lui eut point gardé rancune des torts que, quatorze ans auparavant, Henri avait eut envers lui. Mais il n'en était point ainsi ; l'orgueilleux jeune homme avait fait sa rentrée au grand jour, s'était mêlé, par un service rendu, à la vie de sa famille ; il venait, comme son égal de rang et comme son supérieur en intelligence, s'asseoir à la même table que lui : c'était plus que Henri n'en pouvait supporter, Henri lui déclara intérieurement la guerre. (Georges 195)

By refusing to allow Sara to dance with Georges Munier, the Malmédie family declares that they will maintain the racial hierarchy that has characterized French colonial society. The "metaphorical battleground" of the Munier / Malmédie conflict is the reconciliatory government of British occupation. The tension between Georges and the Malmédie family doesn't go unnoticed by Lord Murrey, who asks Georges if there is any amicable way of making peace between the two powerful colonial families. Georges informs Lord Murrey of the source of this conflict:

- Je l'ai espéré un instant, milord; j'ai cru que quatorze ans de domination anglaise avaient tué le préjuge que je revenais combattre; je me trompais; il ne reste plus à l'athlète qu'à se frotter d'huile et à descendre dans le cirque.

- N'y rencontrerez-vous pas plus de moulins que de géants, mon cher don Quichotte ?

- Je vous en fais juge, dit Georges en souriant. Hier, j'ai sauvé la vie à mademoiselle Sara de Malmédie !... Savez-vous comment son cousin m'en remercie aujourd'hui ?

- Non.

- En lui défendant de danser avec moi.

- Impossible!

- C'est comme j'ai l'honneur de vous le dire, milord.

- Et pourquoi çela?

- Parce que je suis mulâtre. (Georges 204) 
Lord Williams Murrey's comparison of George's war to Don Quichotte's is quite telling.

The two families are in a social battle; however, the British governor sees Georges' efforts as nothing more than romantic jousting against imaginary enemies. Georges himself admits having harbored the hope that British presence may have put racial tensions to rest; however, the actions of the Malmédie family have proved otherwise. The only way to prove equality would be to marry Sara de Malmédie, which Georges swears he will accomplish in three months (204). As such, Sara becomes the spoils of war; ${ }^{41}$ denial of her hand in marriage would be victory for the Malmédie family, and gaining her hand will be victory for the dandy.

A true gentleman, Georges Munier arranges to meet with Monsieur de Malmédie to ask for Sara's hand in marriage. As the Munier and Malmédie families are two of the most influential on Mauritius, Lord Williams Murrey is in attendance. Georges is flatly refused, despite the fact that Sara herself declares her love for him (268). Enraged at Georges Munier's audacity in asking for Sara's hand, Henri de Malmédie raises a baton he is carrying, gesturing as if to strike Georges. This near assault is not only reminiscent of their initial altercation at the British naval attack, but it demonstrates Henri de Malmédie's belief that he has the right to physically attack individuals of black ancestry. Understanding racism as the reason for both their refusal of Georges's marriage proposal and the posture of physical attack, Georges demands a duel with Henri de Malmédie as satisfaction for the two insults. Henri responds with the ultimate insult to the mulatto dandy: "Je ne me bats pas avec un mulâtre ... "(270). 
In order to force Henri's hand, Georges plans a public insult. The entire city of Port Louis was making preparations for les fêtes de Yamsé, during which Henri de Malmédie was to compete in the traditional horse races. Having entered the race anonymously, Georges resorts to the weapon of public spectacle that characterizes him a dandy. A superior equestrian, Georges outpaces all of the other riders, holding back his horse until the race is between himself and Henri de Malmédie. Before crossing the finish line, Georges pulls his horse neck to neck with Henri de Malmédie's horse and soundly slaps Henri in the face with his riding crop (Georges 291). This seals his enmity with the Malmédie family. To further advance his battle with racist society as a whole, Georges also agrees to lead a slave rebellion (Georges 314).

Georges' efforts to provoke a duel with the Malmédie family get the attention of Lord Murrey, who mysteriously manages to obtain permission for Georges to marry Sara. Georges' response reveals that he is in opposition not only with Malmédie family, but white colonialism as a whole:

Merci, milord, continua-t-il, merci; je reconnais dans ce qui se passé aujourd'hui l'appui de votre généreuse philanthropie et de votre bienveillante amitié. Mais, du jour où $M . d$ Malmédie m'a refusé sa nièce, où $M$. Henri m'a insulté pour la seconde fois, où j'ai cru devoir me venger de ce refus et de cette insulte par une injure publique, ineffaçable, infamante, j'ai rompu avec les blancs ; il n'y a plus de rapprochement possible entre nous. (Georges 329, emphasis mine)

It becomes clear from the above text that Georges Munier's public insult of Henri de Malmédie was more than an effort to provoke a duel ; it was a definitive break with "les blancs." The assault on Henri de Malmédie's person, as well as the refusal to grant Georges Munier the right to marry Sarah Malmédie, place two male bodies in comparison: the body of the white male and the body of le mulâtre who, in Roger 
Toumson's words, is "un nègre qui n'a pas de peau noire" (95). Georges Munier's challenge to the Malmédie family is more clearly understood when we compare Dumas' above text, Roger Toumson's definition of le mulâtre and Nancy Bentley's observation of violence inflicted on a white male body. As Bentley observes, violence or abuse inflicted on a white male body can never be a means to personal dignity. Unlike the idea of violence enacted on the bodies of females or black males, the idea of a white male achieving dignity by suffering physical humiliation is nonsense, heretical and obscene. (Bentley 502 - 503). Lord Murrey, representing the British intervention in the racial hierarchy of a French colony, is asking the impossible; the public humiliation of a white male body could not be overlooked. By asking Georges (le nègre qui n'a pas de peau noire) to do so, Lord Murrey is asking him to renounce his claim to agency and personal recognition by renouncing the whiteness of his body. By the same logic, Georges understood that violence on Henri de Malmédie was a way to guarantee recognition by demanding the Malmédie family act in some way to reclaim their dignity. By publically inflicting physical violence on Henri de Malmédie's body, Georges Munier purposefully sets himself in unending rebellion against white society.

Having separated himself from the white colonizers of Mauritius, Georges continues his journey as a dandy by separating himself from the black population of Mauritius. Either ignorant of or indifferent to his duplicitous agenda to place the lives of black slaves at risk, Georges had aligned himself to the rebel slaves as their leader. To his surprise, the eponymous hero discovers that Lord Murrey has learned aware of the uprising and arranged Georges' marriage to Sara as way of ending the slave rebellion. 
Georges is arrested after refusing to betray the slaves under his charge. The rebel slaves enact Georges' escape by sending him a file that Georges uses to leave his barred cell. Now a fugitive from the law as well as a rebel leader, Georges rushes to Port-Louis to lead the rebellion. When he arrives, Georges sees the rebels drinking from several open barrels of alcohol that Lord Murrey had purchased in anticipation of the uprising. As anticipated, the inebriated slaves were unable to maintain ranks or follow orders. When the revolt fails, Georges sees black rebel slaves as childish and undisciplined.

Furthermore, the behavior of the black population that he leads completely changes Georges' view of the black population. The barrels of spirits that Lord Murrey used to foil the rebellion were a temptation that was too great to resist: "bientôt le naturel I'avait emporté sur la discipline, et meme sur la crainte." (Georges 341 - 342) Already "rompu avec des blancs" in order to lead the slave revolt, Georges now breaks completely with the black race as well:

Ainsi, tout ce long labeur de Georges sur lui-même était perdu; toute cette haute étude de son propre cœur, de sa propre force et de sa propre valeur était inutile ; toute cette supériorité de caractère donnée par Dieu, d'éducation acquise sur les hommes, tout cela venait se briser devant les instincts d'une race qui aimait mieux l'eau-de-vie que la liberté (Georges 342-343)

Wounded from the rebellion, Georges eventually falls into the hands of the Britishcontrolled Mauritius government. At this point in the text, Dumas completes George Munier's most dramatic demonstration of dandyism with the use of another Romantic literary convention: the romantic prison.

Evoking memories of revolution and the oppression of ideas, the literary prison holds a place of prestige in the French romantic imagination (Brombert 3). Rebelling against 
the white colonial society and rejecting the black community for whom he has nothing but contempt, Georges Munier will become a metaphysical rebel. In his book The Hero in French Romantic Literature, Georges Ross Ridges defines le dandy as a fusion of social and metaphysical rebellion (96). In prison, Georges defies both death and the religious system of his time. As soon as he is physically able to stand before colonial legal system, Georges takes responsibility for his role as the leader of the slave rebellion. Georges' testimony is not a defense, but rather an explanation of the war he has fought his entire life. He only stops short of mentioning that the true reason for his rebellion was the refusal of his proposal to marry Sara de Malmédie:

Ce que Georges dit ne fût point une défense, ce fût l'histoire de toute sa vie: il ne cacha point qu'il était revenue à l'ile de France dans l'intention de combattre, par tous les moyens possibles, le préjugé qui pesait sur les homes de couleur; seulement, il ne dit pas un seul mot des causes qui avaient hâté l'exécution de son projet. (Georges 400) Having protected his family from any complicity in his actions, Georges Munier sets himself to defy death and religion. The almost inhuman level of self-control that he has developed all of his life culminates in a stubborn refusal to let his enemies see him emotionally disturbed:

Sembler maître de soi, ne trahir par sa mise comme par sa conduit, aucun attachement particulier, telle est la meilleure méthode pour dominer les autres, ou, au minimum, éviter leur emprise (Cannu 90-91)

Georges' metaphysical rebellion takes the form of a rebellion against the religious system of his time. Throughout the novel, Georges is described as a prideful man; he admits his pride before the priest who comes to visit him. Georges' pride, however, is stated in the text as what sustains him: "Mais aussi, à cette heure même, c'était cet orgueil qui le soutenait, c'était cet orgueil qui le faisait fort, c'était cet orgueil qui le 
faisait grand." (404) In the romantic prison cell, Georges Munier's rebellion is compared to the rebellion of Satan; a rebellion that interested both early romantics and would inform images of dandyism in mid-century French literature. The priest is not a person of authority with Georges nor is he Georges' confessor; in fact, Georges teaches the priest as much as the priest talks with him (408). The day of his execution, Georges prepares himself for public display in the same manner that he prepared himself for Lord Murrey's ball. The priest warns Georges of the pride that he fears may cost Georges his soul:

Le prêtre entra et regarda Georges. Jamais le jeune homme n'avait été si beau : ses yeux jetaient des flammes, sont front semblaient rayonnant.

- Oh! mon fils, mon fils ! dit le prêtre, gardez-vous de l'orgueil ; l'orgueil a perdu votre corps, prenez-garde qu'il ne perde encore votre âme. (Georges 400)

Georges Munier's rebellion is not only against religion, but also death itself. Georges purposefully befriends his executioner, asking him the details of his execution and promising a diamond ring as payment for his services. The day of his execution, Georges' exchange with his executioner shows contempt for death:

Georges alors aperçut le bourreau, qui se tenait dans l'ombre de la porte.

- $\quad$ Ah! C'est vous, mon ami? dit-il. Approchez.

Le nègre était enveloppé dans un grand manteau et cachait sa hache sous son manteaux.

- Votre hache coupe bien ? demanda Georges.

- Oui, répondit le bourreau, soyez tranquille.

- C'est bon ! dit le condamné. (Georges 411)

These final images of metaphysical rebellion not only complete Georges's portrait as le dandy, they convey the idea that the mixed-race dandy has no society to which he belongs. He is separated by increments from the white society who refuses to recognize him, and from the black society who he sees as being inferior. Despite the aristocracy of 
wealth into which le mulâtre could be born, the negritude of le mulâtre would always set him apart. This is the case with Georges Munier, who defies society again by marring Sara Malémedie on his way to the scaffold. After being rescued by his father and brother after the marriage ceremony, Georges Munier displays his final act of societal rebellion by fighting Lord Williams Murrey at sea. By killing Lord Murrey, Georges Munier rejects the possibility of living in peace with a society that tolerates the racial prejudice against the mixed-race population of Mauritius.

The third and final portrayal of le mulatre romantique is the trickster, the mulatto who would attempt to conceal his blackness by racial performativity. In the final section of this chapter, I will examine the character of Jacques Munier as a trickster and the story of Jacques Munier as a passing narrative.

\section{Jacques Munier: Le Mulâtre as Trickster}

The third and final aspect of le mulatre romantique that Alexandre Dumas portrays in Georges is the image of the trickster, or the mulatto who simply disregards the social ordering of race. Taking advantage of the indeterminacy of his race, the trickster benefits from access to a world from which they would otherwise be excluded. This particular representation of mixed-race males is extremely rare in metropolitan French Romantic literature; the only other figure of any significance ${ }^{42}$ before Dumas's Georges being an unnamed planter in Victor Hugo's Bug-Jargal (1826). Of the three mulatto characters that dominate this historical novel, Jacques Munier is by far the most modern, for he indulges in what would later come to be known as "race performativity" or race passing. Jacques Munier can be easily studied as a romantic character by 
examining him as a "rogue male" or "demonic male" that was common in Romantic literature; the rogue male was a certain type of Romantic hero, an adaptation of the wily Ulysses character who lives by his wits (Boyesden 595). By adding the dimension of race, however, Dumas expands the representation of the rogue male. In this manner, Dumas distinguishes the character of Jacques Munier from other representations of le mulâtre in nineteenth-century French literature by exploring the complexities of race passing. In this portion of Chapter Three, I will examine how Alexandre Dumas expands the Romantic trope of the demonic male in order to present a new literary image, the mulatto who is a trickster. Jacques Munier's story becomes a passing narrative as Dumas creates a trickster who, due to his connection with his generative space, finds himself able to indulge in race performativity.

Dumas wastes no time casting the character of Jacques Munier in complete ambiguity. The reader realizes that as the son of a dark-skinned mulatto man Jacques Munier must be biracial by birth; however, Jacques's phenotype places his age, ethnic origin into question:

L'ainé des deux enfants était ... un grand garçon de quatorze ans, à qui I'habitude de la chasse, plus encore que son origine africaine, avait brunie le teint ; grâce à la vie active qu'il avait menée, il était robuste comme un jeune homme de dix-huit ans ; aussi avait-il obtenu de son père de prendre part à l'action qui allait avoir lieu (Georges 53 - 54) Dumas emphasizes Jacques' ambiguous, liminal character by calling attention to the young man's weapon of choice: un fusil à deux coups. A careful reading of Jacques' introduction in the text makes Dumas' metaphor quite clear; Jacques' duality will be one of the keys to his success. It is with this two- barreled rifle that Jacques makes a name 
for himself as a hunter, and the skill with which he wields this weapon disguises his youth:

Il était armé de son côté d'un fusil à deux coups, le même dont il avait l'habitude de se servir dans ses excursions à travers l'ile, et avec lequel, tout jeune qu'il était, il s'était déjà fait une réputation d'adresse que lui enviaient les chasseurs les plus renommés (Georges 54)

It is also with this two-barreled weapon that Jacques exhibits his French nationality by fighting alongside his father to repel the attack. However, the most telling metaphorical use of Jacques' weapon is when Jacques uses his weapon to exert his "whiteness" in front of the villainous Monsieur de Malmedie. Jacques Munier comes to the defense of his younger brother after witnessing Henri de Malmedie's attack. Jacques disarms Henri de Malmedie and strikes the boy to the ground. Monsieur de Malmedie insists that Jacques be whipped for striking his son Henri. Jacques Munier stands up to this insult by seizing his weapon of choice. This weapon, recently brandished against the English, seems to give Jacques a type of adult masculinity and sense of agency so lacking in his father:

- Me faire fouetter, moi, dit Jacques en ramassant son fusil à deux coups et en redevenant d'enfant homme. Eh bien, venez donc vous y frotter un peu, vous, Monsieur de Malmédie?

- Taisez-vous, Jacques ; tais-toi mon enfant, s'écria Pierre Munier.

- Pardon, mon père, dit Jacques, mais j'ai raison, et je ne me tairai pas. M. Henri est venu donner un coup de sabre à mon frère, qui ne lui faisait rien ; et moi, j'ai donné un coup de poing à M. Henri ; M. Henri a donc tort, et c'est donc moi qui ai raison. (Georges 71, emphasis mine)

Again in this passage Dumas makes a veiled reference to Le Code Noir, the French social legislation that forbids black persons from striking a white person. Using his considerable physical strength to defend his younger brother George, Jacques Munier 
draws blood from Henri Malmédie. Malmédie's order that Pierre Munier have his son whipped is, in essence, calling the Munier family the descendants of slaves and thus subject to Le Code Noir. Jacques' challenge to Malmédie, armed with his double barreled rifle, can be thus read as Jacques' claim to whiteness and equality with the Malmédie family despite his bi-racial heritage.

Jacques Munier's response to his father's public humiliation is much different than Georges. The steel-willed child bursts into tears, but Jacques Munier swears vengence: “De son côté, Jacques se mordait les poings de colère, et jurait qu'un jour il se vengerait de Henri, de M. de Malmedie et de tous les blancs." (Georges 73) In order to protect him from repercussions, Jacques is sent along with Georges to Europe. Unable to focus on his studies in France, Jacques pursues and finds great success as a seaman, pirate and slave trader. For Jacques Munier, the sea is a "generative space" that defines his individuality and eventually gives him agency. In her book Romancing the Novel, Adventure from Scott to Sebald, Margaret Bruzelius describes the "rouge male" or "the demonic male" and explains his connection to a certain space that energies and empowers the character. Jacques comes into manhood and defies the Malmédie family after repelling an attack by the sea. The sea becomes the means of his chosen profession. The sea enables this character to become, in the romantic literary tradition, the "rouge" or "demonic male":

The demonic male is characterized . . . by his visceral connection to the generative space. This space is not only the source of the hero's story but of the demonic male's power, and it feeds his ability to circumvent the rules of the public world.... The demonic male's connection to the generative space also provides him with the power to control others and transform himself. ... (Bruzelius 93) 
There is an important connection in romantic and the modern passing narrative;

between the shape-shifting rogue male who can transform himself, and another literary trope: the trickster. I argue that the rogue or demonic male's transformative ability is very similar to the mulatto who makes the choice to "pass for white." Bruzelius expands the description of the rogue male as one whose transformative ability can take the form of being other than what they are: "While heroes in adventure are condemned to be only themselves, incapable of anything but the whitest lies, the demonic male can disguise himself, exhibit male and female qualities, and embody a dizzying array of personae" (91).The mulatto has commonly been referred to as a trickster who at best could disregard social conventions of race and, at worse, presents the idea of race passing: "The mulatto is the trickster figure par excellence, one who traverses social worlds, who is both everywhere and nowhere" (Derby 52). "Ultimately, the passing figure becomes one that produces its own meaning and one to whom viewers attach various meanings within the confines of race ... Because the passing figure signifies or confuses meaning, it is a trickster." (Hollens 61). Connected to the generative space of the Atlantic, Jacques Munier discovers the transformative ability of race passing or, more accurately, masters the process of race performativity.

"Passing" or race performativity in literature was not studied in depth until the twentieth century, which makes Dumas' representation of Jacques Munier all the more original. Whereas "passing" can refer to the crossing of any boundary that divides groups, the term is most often used in a racial context. In her book Clearly Invisible: 
Racial Passing and the Color of Cultural Identity, Marcia Dawkins comments on the use of the term "passing" as being most common in a racial context:

Passing, usually understood as an abbreviation for "racial passing," describes the fact of being accepted, or representing oneself successfully as, a member of a different group. Generally speaking, passing refers to the means by which nonwhite people represent themselves as white. (1)

Motivations for passing is most often in order to enjoy some type of privilege or social standing that presumes whiteness as a prerequisite; economic empowerment or social mobility are among the most common. However, motivations may be strictly emotional, a manner of enacting revenge on an unjust racial system, or simply a process which the passing figure enjoys:

Passing may even lead an individual who succeeds in it to a feeling of elation and exultation, an experience of living as a spy who crosses a significant boundary and sees the world anew from a changed vantage point, heightened by the double consciousness of his subterfuge. Thus persons who pass may enjoy their roles as tricksters who play... a "capital joke" on society ... Passing my lead to the higher insight of rising above and looking through the "veil" of the color line, to an experience of revelation, to seeing while not being seen ... (Sollors 253)

As the eldest son of a free, wealthy family Jacques Munier's motivations to pass seem to be reduced to the psychological. In her introduction to the book Passing and the Fictions of Identity, Elaine Ginsberg explains the connection between race passing and trespassing:

As the term metaphorically implies, such as individual crossed or passed through a racial line or boundary - indeed trespassed - to assume a new identity, escaping the subordination and oppression accompanying one identity and accessing the privileges and status of the other (3)

In his book Neither Black Nor White Yet Both: Thematic Explorations of Interracial Literature, Werner Sollors explains that motivations for passing include the love of 
deception, acts of subversion or the desire for revenge (250-251). I argue that Jacques

Munier's principle motivation was the latter of these three: it was in racial

performativity that Jacques Munier realized the vengeance on all white men to which he aspired after his battle with the British. Unlike his father Pierre and his younger brother Georges, Jacques Munier will employ his wiles to subvert the prejudices of a society that has victimized his family. This results in Jacques Munier being a different type of marginalized racial character, one who overcomes marginalization by exploiting the racial system itself.

When Jacques Munier is reunited with his family after several years absence, neither his father nor his younger brother recognize him. His physical appearance is even more enigmatic than when he was a boy. The complete ambiguity of his appearance calls not only his biological race, but his nationality into question: ... son visage et ses mains, hâlés par le soleil des tropiques, étaient arrivés jusqu'à la teinte des Indiens de Timor ou de Pégu. Il était vêtu de la veste et du pantalon de toile bleue particuliers aux chasseurs de l'ile de France, et avait, comme eux encore, un large chapeau de paille et un fusil jeté sur l'épaule ; seulement, il portait, de plus qu'eux, suspendu à sa ceinture, un sabre recourbe, de la forme des sabres arabes, mais plus large, et ayant une poignée à la manière des claymores écossaises. (Georges 214)

Living in connection with his generative space and participating in an illegal trade, Jacques Munier has learned to present himself in any identity that will give him the greatest level of agency. This does not restrict reading this character as a trickster who indulges in race passing: "Not always associated with a simple binary, some instance of passing ... demonstrate the multiplicity of racial or related identity categories into which one might pass." (Ginsberg 3). In possession of a white body, Jacques Munier could present himself as any number of "non-black" racial identities by changing the 
flags and colors of his ship and simply acting as if he belonged to other cultures. In this manner, Jacques Munier's race passing is more accurately examined as "race performativity." Borrowing Judith Butler's concepts of gender performance in her work Gender Trouble (1996), critical race theorists (such as Rita Keresztesi Treat, "Writing Culture and Performing Race in Morning Dove's 'Cogewea, The Half-Blood'; Gil Jagger's Sexual Politics, Social Change and the Power of the Performative; and Nadine Ehlers' Racial Imperatives: Discipline, Performativity and Struggles against Subjection) all examine race as performance. An individual can, as a result, present themselves as a different race by "subversive repetition" and "discursive resignification" (Butler 16). Race, therefore, is performative as well as biological, and can redefined by an individual's actions. In his book To Be Suddenly White: Literary Realism and Racial Passing, Steven Belluscio observes that if passing can be thought of as the performance of ethnicity, then passing is not focusing so much upon what one is as upon what one does (253). Jacques Munier, acting as a white pirate and slave trader, assumes the identity of a white male by exercising the prerogatives of white masculinity.

One of the principle areas in which he exercises whiteness is in his several romantic adventures. Throughout his travels, Jacques Munier presents himself as a white European:

Comme il nageait dans l'or et roulait sur l'argent, les belles créoles de la Jamaïque, de la Guadeloupe et de Cuba lui avaient fait d'une fois les doux yeux; il y avait même des pères qui, ignorant que Jacques fut un mulâtre et le prenant pour un honnête négrier européen, lui faisaient de temps en temps des ouvertures sur le mariage ... Quant à des maitresses, Dieu merci, il n'en manquait pas ; il en avait de noires, de rouges, de jaunes et de chocolat, selon qu'il chargeait au Congo, aux Florides, au Bengales ou a Madagascar ... Jacques était sensuel comme un créole. (Georges 231 - 232) 
The above text presents Jacques Munier as a man who could share the same point of view towards creole women as a white man. The fact that he was quite wealthy made him attractive to women throughout the Caribbean, but it was his apparent whiteness that made him attractive to their families. Despite his racial performativity, he is described as "sensual comme un créole," referring to his black heritage. The heat of the Caribbean was portrayed in French Romantic literature as being detrimental to the strength and vitality of white Frenchmen and women, aging them prematurely; however, the black and mulatto race were rumored to increase in laziness and sensuality due to the tropical heat (Garraway 232-233).

The aspect of Jacques Munier's character that expands his story from that of the romantic figure of the demonic male or trickster into an authentic, modern passing narrative is the internal, psychological journey that he experiences. The process of race passing inevitably marks the trickster's psyche as he achieves two necessary goals: hiding his past and coming to terms with his whiteness. The bi-racial individual who chooses to engage in race-passing must keep their past a secret (Sollors 253). This need for secrecy places a strain on family relations, particularly between the older generations who cannot pass for white. This places a significant distance between Jacques Munier and Pierre Munier and makes a united family unit impossible:

Le pauvre père Munier avait fait tout ce qu'il avait pu pour garder son fils près de lui; mais Jacques lui avait répondu de sa douce voix:

- Cela ne se peut pas, mon père.

Et, à l'intonation tendre mais ferme de cette voix, le vieillard avait compris que c'était de la part de son fils une résolution prise ; il n'avait donc pas insisté. (243) 
In her book Racial Imperatives: Discipline, Performativity, and Struggles against

Subjection, Nadine Ehlers connects the process of race passing to the notion of social death:

To pass meant to leave behind, to subject oneself to the loss of a prior identity . . . to pass-over or pass-through into whiteness was indisputably to abandon a 'real' and substantive social identity. The notion of loss is present in the very terminology of passing. 'Passing' and 'crossing-over' are both metaphorically employed to describe the transition from life to death, or to signify a journey to a realm beyond the earthly plain. Thus, to pass or cross-over racial lines calls forth imagery of an experience that is a form of death, a social death that is a passing-on, a passing away (59)

The impact of studying Jacques Munier as a trickster who participates in race passing is the realization that Jacques Munier gains agency, but loses identity in the process. Jacques Munier loses the only family that he has, while simultaneously avoiding the establishment of a family of his own.

Another consequence of Jacques Munier's passing, or his racial performance, is the revelation of the contempt that he has gradually developed for the black race as a whole. Elaine Ginsberg describes this process as one in which the passing individual must realize everything that having a white identity entails, because one cannot pass for something that one is not. In other words, the ability to successfully pass assumes the presence of a "pre-passing" identity that one is (Ginsberg 4). The subtext of the male mulatto's body suggests that if a mulatto could pass for white, he could conceivably share the prejudices of white society and despise their own heritage. Jacques Munier's connection with his generative space also provides the opportunity to develop contempt for the black (non-mulatto) race. As a slave trader, Jacques Munier notices with disdain the love that the fictional slaves have for alcohol and their proclivity for 
war. These two aspects of the African culture result in a continual supply of slaves for trade:

La guerre, parfois éteinte en Europe, est éternelle en Afrique; il y a toujours quelque peuplade qui a soif, et, comme les habitants de ce beau pays ont remarqué, une fois pour toutes, que le plus sûr moyen de se procurer des prisonniers était d'avoir beaucoup d'eau-de-vie ... Quand les prisonniers manquaient, les mères vendaient leurs enfants pour un petit verre (Georges 227)

This disdain for the black race as a whole and the resulting self-hatred comes to the forefront when Jacques Munier meets his younger brother and informs him of his plans to leave Mauritius. Having learned of Georges's public humiliation of Henri de Malmédie, Jacques invites Georges to flee Mauritius with him. When Georges refuses and informs Jacques of the Malmédie's refusal to allow Georges to marry Sarah, Jacques reminds him of their place in French colonial society: "Sans compter, mon cher, que nous sommes de mulâtres, pas autre chose." (300) His subtle self-hatred becomes more evident when he informs Georges Munier of Henri de Malmédie's plan to ambush and publically humiliate Georges. Having presented himself as a trader from Holland named Captain Van den Brock, Jacques has learned of their plans: "On me prenait pour un brave Hollandais, pour un pur-sang; on ne se défiait pas de moi" (301). In one of his many white personae, the trickster is privy to information that he would not otherwise have. He informs Georges of the plot against him:

- Qu'un de ces soirs, pendant que tu serais à la ville, on s'embusquerait à huit ou dix sur la route de Moka; qu'on te surprendrait au moment où tu t'y attendrais le moins; qu'on te coucherait sur une échelle, et qu'on te donnerait vingt-cinq coups de fouet.

-Les misérables! Mais c'est le supplice des nègres !

-Eh bien, que sommes-nous donc, nous autres mulâtres ? Des nègres blancs, pas autres chose. (Georges 301) 
In race passing, therefore, Jacques Munier finally realizes his revenge against the Malmedie family and the system of racial discrimination that has marked his family. Not only does he live as a white male, he accesses information that he uses to thwart plans to further humiliate his family. However, this revenge has come at a price; Jacques Munier has internalized a type of self-hatred that makes it impossible for him to make the kind of stance that either his brother or his father have made. As the trickster who participates in race passing, Jacques Munier represents the mulatto who completely rejects his blackness: "Chez les Mulâtres tout se passe en somme comme si le Blanc en chacun d'eux déplorait - ou méprisait, même - cette espace de « double » nègre avec lequel il est forcé de cohabiter." (Hoffman 246) Jacques Munier is the clearest representation of this particular image of le mulâtre.

The final chapter of Dumas' novel recounts the story of all the three mulattoes in a sea battle. On his way to his execution, Georges Munier is met by Sarah Malmédie who proposes to him publically. After a rushed marriage, Georges and Sarah are rescued by Jacques and Pierre Munier and escape to Jacques' ship the Calypso. The three mulattoes and the new bride soon discover that they are being pursued by Lord Williams Murrey's ship, the Leycester. A daring battle at sea results in the Calypso crew, under the leadership of Jacques Munier and his family, managing to destroy and sink the powerful British ship. The three mulattoes have all realized, in various ways, the agency to which they aspired: Pierre Munier has regained his dignity, Jacques Munier has saved his family by duping society, and Georges Munier has married Sara Malmedie. The analysis of the three characters as the early romantic hero, mulatto dandy and trickster explain 
much of the attendant anxiety that Nancy Bentley refers to in her work. All three characters subvert French society that, regardless of its republican ideals, was indeed greatly dependent on a racial binary. The male mulatto challenges this racial inequality by claiming his right to agency, be that claim through military rebellion, societal elitism or trickery. However, the novel ends on a suspended note; the Munier family is exiled from their homeland with no destination. The final words of the eponymous hero reveal a type of ambiguity in relation to society: "Si je ne devais pas vivre avec toi, Sara, dit Georges en se tournant, sur mon honneur, je voudrais mourir comme lui!" (Georges 452) Georges's admiration of the man whom his family has killed reveals a kind of ambivalence towards society as a while. I argue that this aspect of the novel underscores the romantic nature of Dumas' characters. Le mulâtre romantique has a choice: he can either assimilate into society by renouncing personal agency, or embrace his agency and accept an ambiguous position in society. In this manner, I argue that le mulâtre romantique fits into the company of romantic heroes at large. In his article "Self, Society, Value and the Romantic Hero," Fredrick Garber comments on the ambivalent nature of the romantic hero towards society:

Society, for these heroes, no matter what degree they considered themselves unique, special or merely different, obviously had much to do with the terms under which they chose to assert themselves. The hero may insist that he makes up his own rules (and there is always some sense in which he does), but the very nature of society and of the structure of his own personality find points of antagonism which prove to be elements in a mutual attraction as well as a necessary repulsion. (324)

The personal agency and quest for recognition that the eponymous hero is realized, in great part, by his marriage to the beautiful Sara Malmédie. By demanding recognition as a black male who has won the affections of a white female, George's character 
expands the common nineteenth century theme of interracial romance. The theme of le mulâtre and interracial romance is the subject of the next chapter. 
Chapter Six: Surviving Storms and Defying the Symbolic Order: Le Mulâtre and Interracial Romance

The theme of impossible love, or at least a love of which society at large would not approve, occurs often in French Romantic literature and is quite important in regards to the representation of race in the French Romantic tradition. As Doris Kadish observes in Politcizing Gender: Narrative Strategies in the Aftermath of the French Revolution, romantic love stories in the nineteenth century are often related to post-revolutionary political issues (111). How would romantic love stories and the "post-revolutionary political issues" of race be represented in French metropolitan literature?

Althought the theme of interracial love (also known as le couple domino) was common in French Romanticism, the combination of persons usually consisted of a white man and a black woman. Le couple domino consisting of a black man and a white woman represented a taboo that eventually resulted in the death of one or both characters. In such couples, the black male initiated the romantic interest. William Cohen observes the popularity of le couple domino in his seminal work on race and French civilization The French Encounter with Africans:

Nearly all novels that contained black characters included a discussion of interracial sex. The black's presumed excessive sexuality was usually expressed in an attack on innocent white womanhood. The good black was the one who had the chance to have sexual contact with a white woman but who resisted (246)

The black male who passed this boundary was usually either deranged (the character of Féo in Chapter Three, Le Mulâtre Gothique), or sentenced to suffer from a love that could never be requited: “Intrinsèquement impossible selon les préjugés de l’époque, l'amour du Noir pour une Blanche n'a droit d'exister que comme souffrance, comme 
torture intérieure." (Chalaye 23). The idea of a white woman who would willingly participate in an interracial romance was unthinkable; the white woman who would defy societal norms of race to participate in such a romance even more so. The idea of $l e$ couple domino also seemed to be consistently accompanied by the unusual signifier of a slave rebellion or military coup. In his book Islands and Exiles, Chris Bongie observes this connection between the themes of revolt and interracial romance in French Romantic fiction:

It is this displacement, this excessive connection between romance and revolution, upon which nineteenth-century Romantic novels ... depend: to talk revolution, for them, is equivalent to talking (interracial) romance. $(220-221)$

This changed with the interest of le mulâtre in French literature after 1830. Bolstered by the changing literary tenents of Romanticism ${ }^{43}$ and the more racially tolerant July Monarchy, images of le mulâtre began to resemble more closely the traditional romantic hero. A fervent abolitionist before his reign, Louis-Philippe established an administration that was much more racially liberal than those of either Louis XVIII or Charles X. Increasing numbers of mixed-race children came to France for education, mastered the French language, established important social and political networks, and returned to the colonies to assume places of influence in the French Caribbean. Consequently, there was a significant increase in representation of mixed-race planters at l'Assemblée Nationale, which irritated the white French creole population who saw blood purity as one of their few remaining social and political assets. Anxiety was more intense when evoked by mixed-race males, a population that was increasingly educated, cultured and affluent. Shared by both the colonial and metropolitan population, this 
anxiety was most likely rooted in the possibility that white women may choose them as suitable mates. Eventually this racial phobia found voice in the literature of the July Monarchy. Rebecca Schloss comments on the political anxieties evoked by such literature in her book Sweet Liberty: The Final Days of Slavery in Martinique:

... the idea that a white woman could love an enslaved or free man of African descent, and cast aside a white man in his favor, flew in the face of elite ideals of white femininity and masculinity, not to mention concerns about racial purity and discussions of beauty as white. As a result, the stories touched a deeply felt, if never spoken, fear that indeed white women might choose such relationships if given the opportunity (Schloss $122-$ 123)

The thematic background of interracial romance involving a white female in French literature after 1830 undergoes an interesting and significant shift. The scenes of rebellion that provide the background for the texts Chris Bongie refers to are replaced in certain texts by life-threatening tropical storms. In this chapter I will examine two texts of French Romanticism: Les Epaves by Mme Charles de Reybaud (1836) and Georges by Alexandre Dumas (1843). In both of these texts, terrifying tropical storms provide the background in which le couple domino meet for the first time, defy societal acts of racism and sexism, and declare their love for each other. In both of these texts, the male is bi-racial. A mixed-race male involved in an interracial relationship was one of the ultimate rebels, and therefore suitable material for the rebellious romantic hero:

Dans le discourse raciologique des auteurs blancs du début du XIXe siècle, le désir que le nègre - et plus précisément le métis - éprouve pour la jeune créole est une impertinence et une vanité causant la perte du prétendant qui a cru pouvoir transgresser les tabous de la société coloniale (Maignon-Claverie 75)

The tropical storm occupied a particular space in the French Romantic imagination. Popularized by Bernadin de Saint-Pierre in Paul et Virginie, the tropical storm or 
hurricane seems to both announce and prohibit romantic relationships that transgress societal taboos. A Lacanian reading of Paul et Virginie provides insight into how the tropical storm or hurricane came to have special meaning in the French Romantic imagination. Representative of the Law or the Symbolic Order, the nom/non-du-père is the power of any society to disapprove of the relationships that structure it. Unlike the eponymous heroine of Saint-Pierre's novel, le mulâtre and the white woman in each of these works survive the storm. Furthermore, the colonial setting of these two novels, Martinique and l'Isle de France, introduce unique multi-cultural backgrounds for the protagonists. The survival of the two lovers, I will argue, is symbolic of both the le mulâtre and the white female claiming personal agency in a racist and patriarchal symbolic order. As such, le couple domino that consists of le mulâtre and the white female in these two works marks an important transition in the representation of black masculinity in Romanticism.

In order to support this hypothesis, I will first establish the tropical storm as a paternal metaphor for le nom / non-du-père in the hugely popular novel Paul et Virginie (1788). Then I will briefly trace the history of both Martinique and Mauritius to demonstrate show each of these colonies provide the ideal geographic setting for the authors of Les Epaves and Georges, respectively, to place le mulâtre as the black male in an interracial romance. As Roger Little states in Between Totem and Taboo: Black Man, White Woman in Francographic Literature, treatment of Blanche / noir relationships are influenced by the date of the composition, the culture of the author and the geographical site of the action (14). Finally I will show that, through various levels of 
intertextuality, both Mme de Reybaud and Alexandre Dumas use the tropical storm to establish the agency of le mulâtre and the white woman in French Romantic literature.

\section{$\underline{\text { Le Nom / Non du Père: The Tropical Storm as a Lacanian Paternal Metaphor }}$}

Originally a portion in the fourth volume of Bernadin de Saint-Pierre's semi-scientific essay Études de la nature (1788), the story of the two eponymous heroes and their tragic death quickly pervaded many aspects of early French nineteenth-century culture and literature. In his article "Paul et Virginie: The Shipwreck of an Idyll," Lieve Spaas comments on the place this novel made in nineteenth century French culture:

At the time of the French Revolution, Paul et Virginie was read more than any other book. Parents named their children after the protagonists, and the novel resulted in the production of several items bearing the images from the novel, such as stamps, plates, wall paper, fans and ornate boxes and clocks (316 - 317)

The popularity of this novel was so widespread, affecting even the popular culture of the time, that it is safe to assume that even those who did not read the novel was aware of the major points in the text. The strength of Bernadin de Saint-Pierre's work, to his critics, seemed to be contained within his ability to "connect with his readers on a sentimental level through his depiction of the natural world, a depiction which goes beyond a mere account of the natural environment to encompass the moral virtues of those who live in harmony with it." (Ford 119) In Bernadin de Saint-Pierre's texts, then, nature becomes a text in and of itself (Ford 121). The death of Virginie is particularly touching and "provides one of the most memorable scenes in French literature." (Cook 213) The storm that claimed Virginie's life, however, was not the first destructive tropical storm in the novel. When examined as the second destructive storm in the novel, the hurricane that claims Virginie's life takes on a deeper meaning. According to 
Cook, both storms carry connotations of forbidding certain romantic and sexual

passions:

The importance of water images in the novel is evident to any reader. Water has a number of symbolic functions: it isolates the island and guarantees its purity; it is essential to life and its presence in the idyllic habitat is crucial, not least, of course, for Virginie's bath ... . at the very spot where, earlier, Paul had shared the bath; the water now serves to reflect the two palm trees planted at their birth and which now intertwine. Paul's friendship is described as "plus pure que l'eau des fontaines ..." but a fire is burning inside her, a fire which the water cannot extinguish. The harmony and delight of the water is suddenly transformed into the opposing element as the status of water in the novel undergoes a transformation: freshness gives way to burning and Virginie runs to her mother for consolation. This is a dramatic moment, full of latent sexual images; it is followed, in the next passage, by the storm (Cook 212)

The scene described in the quote refers to a midnight bath in which Virginie sought relief for an unspecified mal that had been affecting both her mood and relationship with those who live with her:

Cependant depuis quelque temps Virginie se sentait agitée d'un mal inconnu ... une langueur universelle abattait son corps ... On la voyait tout à coup gaie sans joie, et triste sans chagrin ... Dans une de ces nuits ardents, Virginie sentit redouble tous les symptômes de son mal. Elle se levait, elle s'asseyait, elle se recouchait, et ne trouvait dans aucune attitude ni le sommeil ne le repos. (Paul et Virginie 157-158, 159)

In the above quote, Virginie experiences a combination of emotional and physical distress that would later become known as le vague des passions or le mal of the romantic hero. This mal reaches a frightening extreme as her thoughts turn to Paul and "un feu devorant la saisait" (Paul et Virginie 160) The cause of Virginie's mal (the stirring of romantic passions for Paul) is quite obvious to her mother, who doesn't dare tell her daughter what is happening to her. This awakening of passion is followed by a hurricane that ravages the landscape (161). Despondent over the futures of their children and aware that the same passion that Virginie has experienced will soon be experienced by 
Paul, their mothers agree to allow them to marry as soon as they become of age and are able to provide for the family unit (163). Prospects for their future seem bleak until news arrives from France. Virginie has been named the sole heiress of her great-aunt's considerable estate, and she is sent to France to prepare herself to receive her inheritance. When Virginie refuses to marry against her wishes, she is immediately disinherited and sent back to Mauritius. Virginie's travel back to the French colony takes place during hurricane season, which results in the heroine's tragic and memorable death (225).

The sudden appearance of the storm, the images of water somehow overtaking and overpowering the eponymous heroine, suggests that nature itself is forbidding the progression of Paul and Virginie's mutual child-like affection to a romantic and / or sexual relationship. A substantial amount of scholarship connects the theme of Virginie's bath and the following hurricane to the theme of passion and sexual awakening. In her article "La Chaumiere Indienne: Counterpart and Complement to Paul et Virginie," Roseann Runte notes: "The bath, once symbolic of their purity, is later symbolic of their sexual awakening." (777). Dorothy Betz connects the themes of passion and destruction in her article "Bernadin's Paul et Virginie": "When passion enters the childrens' lives, it appears as evil ... After a night spent cowering from a violent thunderstorm, the families emerge to find the garden in ruins" (139). The second hurricane prevents the marriage to Paul that the reader assumes would have taken place had Virginie survived. In her article "La Mort mystérieuse de Virginie," Janine Rossard notes the impact that Saint-Pierre's novel has had on such writers as Théophile 
Gautier and Gustave Flaubert as well as the Romantic movement overall: "La mort de Virginie est finalement plus le signe d'une sensibilité nouvelle que d'une sensibilité qui finit . . . scène de Virginie à la fountaine ou du naufrage, le vent nouveau du romantisme y souffle." (418).

The scenes of Virginie at the start of her romantic passions and the end of her life connect, therefore, the Romantic themes of forbidden passion and death. However, a careful reading of the novel leaves some doubt as to exactly what aspect of Paul and Virginie's future was forbidden.

In his book Sick Heroes : French Society and Literature in the Romantic Age 1780 1850, Alan Pasco discusses the Romantics's interest with the theme of incest. The idea of incest in Romantic literature was quite common; the act itself did not necessarily have to be committed in any text, it could be implied, inferred or averted (114). Although not related by blood, Paul and Virginie were born into the same creole "family" and, until reaching the age of young adulthood, lived as brother and sister. Therefore, the theme is incest is greatly implied: as Pasco states, "As the century ended, the titillating aroma of incest wafted not just from Bernadin's novel but from legions of others as well (114)." Lieve Spaas also reads a challenging of the incest taboo in the novel: "Because their children are like loving siblings, the sensuality between them inevitably evokes the notion of incest which permeates the novel." (Spaas 319) However, I argue that incest is not the forbidden aspect of the romantic relationship. The transgression that would have taken place had Virginie survived, I suggest, is rather a defiance of the class boundaries that separated the two families. 
Although close in age and raised as brother and sister, Paul and Virginie came from two different worlds. Paul is the illegitimate son of Margarite, a woman of no social standing who was abandoned by Paul's father when she discovered that she was pregnant. Virginie's father died shortly after bringing his wife to the colonies in hope for a better life. The father figure in Paul et Virginie is, therefore, consistently associated with ideas of absence, abandonment or death. As a result, there is the absence of the figure who, according to Lacanian theory, establishes the Symbolic Order by conferring his name and prohibiting certain relationships (le nom-du père / le non-du-père).

Bernadin de Saint-Pierre's novel has traditionally been read as the creation of an ideal space of love and equality, a Rousseauian paradise applied to the family unit. A close examination of the text itself, however, reveals instead a life full of hardship and poverty in which the needs of the family are barely met. Furthermore, nothing in the "education" of either child made it possible to hope for a better future. I therefore propose an alternate reading of Paul et Viriginie; not one of an idyllic paradise, but rather one cut off from society. The two families suffer all of the difficulties that come from societal alienation. As Lieve Spaas notes: "We are far from a Garden of Eden; instead we are in a French colony where the occupants are social exiles who have fled from abandonment and European prejudices." (318) Both Margarite and Mme de la Tour have defied the Symbolic Order by having romantic relationships of which society would not approve: Margarite's lover was an aristocrat and she was not, and Mme de la Tour married a man who was not an aristocrat in spite of that fact that she was. Despite the extremely difficult life they have lived in by defying the class structures of society, 
Margarite and Mme de la Tour agree to continue setting aside societal order by marrying their children and therefore promoting an unacceptable form of exogomy. In order to encourage her daughter's return to France, Mme de la Tour assures Virginie that she will be wed to Paul upon her return: “Je n'ai d'autre projet que de te rendre heureuse et de te marier un jour avec Paul, qui n'est point ton frère" (169). In revealing her plans to marry Virginie to Paul, Mme de la Tour removes the incest taboo only to replace it with the societal taboo of a romance that defies the Symbolic Order. In his article "Harmony and Discord in Paul et Virginie," Malcolm Cook comments on the unlikely future of a relationship that crosses class boundaries in the mind of the reader: ... there are distinctions which are apparent to us and of which the children remain blissfully unaware: the mothers are social opposites ... Is there any likelihood, given these factors, that the couple will ever be able to overcome the obstacles which prevent their union? (Cook 213-214)

The image of the tropical storm, therefore, announces the return of the Symbolic Order/ Replacing le nom / non du père, nature itself forbids the continuance of romance across class boundaries and the possible establishment of a classless society. The paternal metaphor and everything that it implies (the symbolic order of culture, the laws of society, and the prohibition of relationships that give shape to societal structures) are all the more powerful in the absence of a biological father (Bernstein 110).

The fact that Viriginie and Paul are both raised outside of a society that would seem to indicate that both children are of equal social standing. However, according to Lacan's description of the Symbolic Order, education or upbringing does not necessarily change the child's place in society. In her book chapter entitled "Structuralist and PostStructuralist Psychoanalytic and Marxist Theories," Celia Britton notes that the Symbolic 
Order "pre-exists the child, who, even before birth, already has a particular position in the family, probably a name, and so on." (203). In their book Romantic Masculinites, Tony Pinkney, Keith Hanley and Fred Botting refer to the ability of the paternal metaphor itself, even in the absence of a father, to position the subject as a subject of language (67). Despite the efforts of their mothers to create a classless ${ }^{44}$ micro-society, le non-du-père forbids a union (or even the possibility of a union) that would ever allow these ideas to be more than romantic fiction. Virginie has the societal standing of an aristocrat, and language inscribes her and her family into a different social standing than Margarite and her son. When Virginie experiences passions capable of causing her to trespass class boundaries, the tropical storm appears and destroys the life that the two families have struggled so hard to establish. When Virginie refuses to marry inside of her class and returns to Mauritius, the second storm claims her life.

The use of the tropical storm as a paternal metaphor replacing le non-du-père can be applied to the literary representation of other social boundaries as well. In her book Confessional Subjects: Revelations of Gender and Power in Victorian Literature and Culture, Susan David Bernstein notes that the historical and cultural operations of the paternal metaphor also include the aspects of gender and race (112). In the remainder of this chapter, I will examine two texts: Les Epaves and Georges. Both texts portray two protagonists who survive a terrible storm. ${ }^{45}$ Mme Charles de Reybaud and Alexandre Dumas both used Bernadin Saint-Pierre's metaphor of the tropical storm to represent society's disapproval of interracial romances between a white female and a mixed-race 
male. The protagonists survival of the storm, I argue, displays the agency of both le mulâtre and the white woman in the midst of a racist and patriarchal society.

\section{Emancipation by Loving a Mulatto: Mme Charles de Reybaud's Les Épaves}

Les Épaves is one of several novellas written by Mme Charles de Reybaud, the penname of Henriette-Etiennette-Fanny Arnaud. Although currently understudied in the canon of French Romantic literature, Mme Charles de Reybaud's work was very popular in the mid-nineteenth century. Focusing on themes of "slavery, racial prejudices, and oppression," (Krueger-Enz 230) the whole of Mme Charles de Reybaud's oeuvre has been called a type of "feminist-abolitionism" (Weigman 27) that explores the possibility of more humane colonial holdings and greater racial equality if women were in leadership. In this section I will demonstrate how Mme de Reybaud explores both the theme of racial equality and feminine agency. By creating a romance between a wealthy young white French heiress and a mixed-race male, Mme de Reybaud created a story in which le mulâtre becomes both the site of a white woman's romantic passions and the means by which she defies the Symbolic Order. Before proceeding to the literary analysis of this text, I will explore the particular importance of Martinique as the setting for this story.

France was the first European superpower to take major interest in this island, rapidly turning it into a sugar-producing colony requiring a large population of slaves. Martinique was captured by the British during the Seven Years War; however, the income generated by sugar production made Martinique so valuable that France gave up all of Canada in order to regain Martinique in the Treaty of Paris (1763). Martinique 
again passed into British hands during the French Revolution; as a result, France's 1794 abolition of slavery never affected Martinique's black and mixed-race population. When the United Kingdom agreed to recognize the French Republic with the Treaty of Amiens in 1802, Martinique again returned to France; however, Napoleon's re-establishment of slavery again kept freedom out of the grasp of Martinique's slaves. Martinique had a substantial mixed-race population that posed a significant threat to a society based on racial hierarchy:

By the time France regained control of Martinique in 1802, nearly 150 years of racial mixing had made it more and more difficult to distinguish the approximately 10,000 gens de couleur on the island solely on the basis of their skin color. Many administrators and elite colons feared that without skin color as a viable visual demarcation, the supposedly impermeable boundaries between races and classes would disintegrate, heralding the downfall of the colony. Consequently elite Creoles and officials worked hard to thwart any such melding. Despite their efforts, the island's mixed race population grew steadily throughout the Napoleonic and Restoration periods and then mushroomed during the July Monarchy (Schloss 9)

The British captured Martinique again in 1809 and held it until 1814. Martinique's definitive return to French control occurred during the Bourbon Restoration, which had as its goal a repression of revolutionary ideals. The constant passing back and forth of this colonial holding (the most valuable since the loss of St Domingue), resulted in great uncertainty concerning the racial relations on Martinique. France was uncertain how Britain had treated les gens de couleur libres and to what extent manumission was allowed. As a result, France resorted to the application of Le Code Noir to define race relations on the colony during the Bourbon Restoration. The July Monarchy, much more liberal than the Bourbon Restoration, provoked a heightened sense of insecurity among white plantation owners. This insecurity was compounded by the progress of developing 
beet sugar in Europe, which threatened the wealth of those who made their fortune from cane sugar in Martinique.

This is the geographical setting which Mme de Reybaud chooses to explore the theme of interracial romance. Les Epaves is particularly pertinent to the French population that had witnessed the changes in race relations from the Bourbon Restoration to the July Monarchy. Set in 1720, Les Épaves tells the story of a blossoming romance between Cécile de Kerbran, a young French heiress, and a mulatto named Donatien. Cécile is in Martinique under the "tutelage" of Monsieur de la Rebelière and his wife, Éléonore de la Rebelière. The exact nature of the Rebelière's guardianship over Cécile is not fully explained; however, Cécile is described as "a minor" at the beginning of the story and remains under Monsieur de La Rebelière's guidance until the day she becomes an adult, known in the text as her "emancipation" (Les Epaves 75). Monsieur de la Rebelière and his wife are a childless couple in a very unhappy marriage. Originally from Belgium, Monsieur de la Rebelière is described as thin, balding and prematurely aging due to Martinique's hot climate. Originally of very humble beginnings, Monsieur de La Rebelière has managed to increase his social standing by marrying into a wealthy Creole family. Mme de Reybaud goes to great lengths to describe Éléonore as not only white and attractive, but belonging to "la race créole":

Mme de La Rebelière était le type créole dans toute sa nonchalance hautaine et gracieuse ... ses traits étaient charmants, ses cheveux noirs, sa peau délicate et veinée ; elle avait cette pâleur fraiche et animée particulière à la race créole, et ces grands yeux sombres qui sont une beauté rare dans tous les pays (Les Épaves 3)

Éléonore's physical beauty stands in sharp contrast to the negative aspects of her personality. Unlearned and uncultured, she displays the indolence of a spoiled child. 
This unflattering portrayal demonstrates Mme de Reybaud's feminist perspective on a culture that would not provide white Creole women the opportunity for challenges that would develop their character:

The assumption that white women would live in relative comfort, with no need to earn a living, undergirded the idea of appropriate white female behavior throughout the first half of the nineteenth century (Schloss 21)

Both Monsieur de La Rebelière and his wife share a deep seated racial prejudice, and Monsieur de la Rebelière is so cruel to his slaves that Cécile is surprised that there has not been an uprising among his several slaves:

Déjà plus d'une fois, depuis son arrivée à la Martinique, elle s'était demandé, en voyant la misérable condition des nègres, si les quatre cents esclaves de l'habitation La Rebelière ne se lèveraient pas quelque jour contre ce maître, dont le fouet impitoyable ne se reposait jamais (Les Epaves 6)

The Family Romance of the French Caribbean established colonial planters in a paternal position over their slaves (Garraway 34). Monsieur de la Rebelière is also a father figure in regards to his wife, whom he often leaves on their plantation as he travels. As a father figure, he is cruel, sexist and insensitive. As a husband, he is portrayed as an aging, impotent man insensitive to and possibily unable to meet Eléonore's romantic and physical needs. His condescending behavior is displayed when Eléonore insists that he grant her permission to visit "les eaux chaudes," a portion of land in Saint-Pierre where the couple owns a dilapidated cabin that they have not used in the history of their marriage. Eléonore remarks that her husband has failed to take her to visit this property despite promising her several times that he would do so. Her husband grudgingly allows her to take this trip for the sake of silencing her : « Ma chère Eléonore, que vous êtes enfant ! dit tranquillement M. de Rebelière ; il faut bien en prendre votre parti et vous 
accoutumer à tout cela, puisque c'est ici que nous vivrons en famille presque toute l’année. " (39)

A careful reading of Eléonore's insistence on a trip "aux eaux chaudes" recalls the night of Virginie's midnight bath. The emotional discomfort that led Virginie to the basin is similar to the ennui that motivates Eléonore to leave her estate. Virginie's mal is described as a restlessness that compels a trip to a basin:

... depuis quelque temps Virginie se sentait agitée d'un mal innconu ... On la voyait tout à coup gaie sans joie, et triste sans chagrin. . . . Elle errait ça et là dans les lieux les plus solitaires de l'habitation, cherchant partout du repos, et ne le trouvant nulle part (Paul et Virginie 157 - 158)

Virginie's bath is what evokes passionate feelings for Paul, which results in "le feu devorant." Eléonore's mal is described as an ennui that compels her to take the trip to "les eaux chaudes":

... elle se consumait de chagrin et surtout d'ennui ... C'était ainsi qu'elle avait voulu aller aux eaux chaudes, s'aventurant à travers ces campagnes désertes pour le seul plaisir de changer de place et de faire quelque diversion à la monotonie de ses habitudes. (Les Epaves 43)

Eléonore manages to assuage her husband's half-hearted concern for her safety by taking Cécile and a large contingent of black slaves with her. Eléonore tells her husband that she and Cécile will spend the time at Saint-Pierre overseeing the renovation of their dilapidated cabin. Consequently, the dangerous trip again recalls certain portions of Paul et Virginie, which features two women who brave life together in an isolated colonial locale.

The trip to Saint-Pierre is interrupted by a gradually rising tropical storm. Frightened, Eléonore decides to seek shelter at a nearby plantation, relying on her standing as a 
white Creole lady of high society to procure the hospitality of the plantation's owner.

An elderly black female slave answers their knock on the door of the plantation's house.

Hardly recognizing her presence, Eléonore enters the house and brusquely asks for the master of the plantation.

- Je suis Mme de la Rebelière; je vais aux eaux chaudes; le mauvais temps m'a surprise en route, et je vous demande l'hospitalité pour cette nuit.

A cette demande précise et laconique, faite en patois créole, le jeune homme s'inclina respectueusement et répondit en fort bien français :

- Je suis trop heureux, madame, de pouvoir vous offrir un asile ; tout ici est à vos ordres et à votre disposition; veuillez-vous asseoir. Vous devez être fatiguée.

Alors, avec les manières aisées et polies d'un gentilhomme de cette époque, il fit avancer des sièges et donna des ordres pour recevoir la troupe restée dehors. (Les Epaves 45)

Their host is a well-educated young man named Donatien. Donatien arranges accomodations and a meal for Eléonore and Cécile, but chooses not to eat with them. Donatien's accent is not that of a Creole colon, and his physical appearance places his ancestry in almost complete ambiguity:

Tandis qu'il s'exprimait avec un pur accent et l'attitude aisée d'un homme qui sait son monde, Cécile et Mme de la Rebelière le considéraient avec un singulier étonnement. Au premier abord, elles n'avaient été frappées que par la male beauté de son visage ; mais en l'écoutant, la distinction de son langage et se ses manières les surprit bien autrement ; c'était sous tous les aspects l'homme le plus remarquable qu'elles eussent rencontré ... ses traits, d'une régularité qui rappelait les beaux types antiques, exprimait une fierté calme ; ses cheveux, lisses et luisans, ne ressemblaient que par la couleur a ceux des nègres, son teint était clair ; mais de légers nuances bronzées s'étendaient des temps à la région supérieure du front, et ses lèvres minces avaient une certaine pâleur brune. (Les Epaves 48)

Despite his polished behavior and speech, Eléonore correctly guesses that Donatien is not a white Frenchman and most likely the love-child of a plantation romance. Her deep-seated racial prejudice has trained her to believe Donatien beneath them, and she instructs Cecile not to refer to him as "monsieur" (47). Both women, however, find 
Donatien disarming. Eléonore and Cécile have barely begun to make themselves comfortable in Donatien's home when the rain that stopped their journey turns into a tropical storm: “En effet, l'orage venait d'éclater; de larges ondées battaient contre les fenêtres ; les échos profonds de la montagne se renvoyaient incessamment le formidable bruit du tonnerre." (47) Similar to Paul et Virginie, this storm is the first of two that will take place in the text. The tropical storm, replacing the paternal presence of Monsieur de La Rebelière, announces the stirring of romantic passions that will transgress the Symbolic Order of class, race and gender on Martinique.

Eléonore and Cécile discover that Donatien's plantation is not far from "les eaux chaudes," and the two women often visit Donatien's estate while renovating the La Rebelière family cabin. As suggested by the arrival of the tropical storm as well as the rather suggestive images evoked by "les eaux chaudes," both women yield to an increasing passion for Donatien. Younger and raised in France, Cécile finds Donatien completely captivating and immediately becomes infatuated with him:

D’ailleurs ces préjugés de caste, qui parfois réveillaient, dans l'âme de la fière créole, une secrète honte, une sorte d'effroi, ne troublaient pas cette jeune fille élevée en France; elle ne comprenait pas ces distinctions subtiles qui font un nègre d'un homme à peu près blanc; elle ne voyait pas encore, par ses yeux, que les couleurs tranchées, et les nuances ne la frappaient pas, (Les Epaves 21)

Even Eléonore's racial prejudice, formed by a life in Martinique, fails to keep her from falling in love with Donatien. During the six weeks that Eléonore and Cécile spend in Saint-Pierre, Eléonore begins a process of shedding her prejudices in the presence of a truly educated and sensitive man:

Elle était d'ailleurs singulièrement captivée par le langage éloquent et poli du mulâtre ; M. de La Rebelière était un esprit court et stérile qui ne l'avait pas habituée aux belles 
idées ; il lui semblait qu'elle entendait pour la première fois un homme d'esprit, et en cela elle avait raison. (15)

By falling in love with Donatien, Eléonore de La Rebelière replaces one white male body, that of her husband, with another "white" male body, that of Donatien le mulâtre. ${ }^{46}$

The whiteness of Donatien's appearance is essential to the text, for it allows Eléonore to give in to passions that any other black body may have prevented: "eut-il été le premier né d'un roi, il suffisait d'une goutte de sang noir sous sa peau pour le faire descendre à un degré au-dessous du blanc le plus roturier." (Les Epaves 49). The intrigue of Eléonore's one-sided romance is that it is completely forbidden by both class and race. Eléonore quickly enters into a type of interior torment by desiring a man that her prejudices, more so than her marriage, denies her. Donatien's captivating presence is more than physical; Eléonore feels a respect that she has not experienced with her husband:

One reason why she is so attracted to Donatien, despite her racial prejudices, is that he treats her politely and respectfully, unlike her husband .... Now, for the first time, Eleonore is spoken to as a person with an opinion who can appreciate "les belles idées" and not just an ignorant creole woman. (Krueger-Enz 160)

As a result, le mulâtre becomes the catalyst by which Eléonore realizes her dissatisfaction with the limitations placed on her by French colonial society.

Eléonore and Cécile's stay in Saint-Pierre is unpleasantly interrupted by the arrival of Monsieur de la Rebelière himself: "Un soir cependant M. de La Rebelière arriva; sa femme et Cécile venait de rentrer; toutes deux pâlirent en le voyant." (Les Epaves 57) Monsieur de La Rebelière announces that they will leave the following afternoon, sending his wife and Cécile into a depression that lasts the rest of the day. Monsieur de 
La Rebelière fails to notice the chagrin of either his wife or his young ward. He does notice, however, the only other plantation that exists near their cabin. He asks his wife to whom it belongs, and learns that the habitation and the slaves on the habitation belong to a mulatto named Donatien. The proximity of a mulatto to his wife and young ward appeases, rather than evokes, his spousal jealousy:

- Quelle est donc cette case neuve la haut sur la montagne? Vous ne m'aviez pas dit que nous avions un voisin, ma chère Eléonore ; comment s'appelle-t-il ?

- C'est un mulâtre nommé Donatien, répondit-elle froidement. A ce mot, les soupçons qui bourrelaient $M$. de La Rebelière s'évanouirent subitement ; il ne lui vint pas à l'esprit que sa femme put avoir seulement jeté les yeux sur un homme de cette espèce-là.

- Un mulâtre ! répéta-t-il avec un long soupir comme un homme tout à coup soulagé d'un poids énorme, un mulâtre! Autrefois on ne voyait guère que des noirs et des blancs, mais aujourd'hui cette race mêlée est partout. (Les Epaves 59)

After dinner that evening, Eléonore advises Cécile to say nothing of their visits to Donatien's estate due to her husband's prejudices: "Si vous saviez ce que c'est les préjugés de caste!" (Les Epaves 57) Eléonore's passion for Donatien seems to have awakened in her a desire to be free from her husband's (and be extension, creole society's) perspectives on life. Life with Monsier de la Rebelière resembles a form of slavery, and Eleonore deeply dreads returning to that life: “Ah! Ma chère Cécile, c'en est fait du bonheur que j'avais trouvé ici; je retombe sous le joug; si vous saviez quelle supplice c'est de vivre avec M. de La Rebelière. (Les Epaves 57) Attempting to give voice to her passions, Eléonore withdraws from her husband that evening and writes Donatien's name several times on a large piece of paper. Strewn with hearts and childish pictures, the paper betrays Eléonore's romantic feelings for Donatien. Monsieur 
de La Rebelière's response to finding this paper betrays both the level of his racial prejudice and his potential for spousal abuse:

Un peu avant le jour, M. de La Rebelière s'éveilla et s'aperçut que sa femme n'était pas encore couchée. Alors il se leva doucement, et vint voir ce qu'elle faisait. Elle s'était endormie, la tête appuyée sur une table. Sa main, qui tenait encore la plume, reposait sur une grande feuille de papier toute barbouillée de chiffres, de cœurs enflammés, et où le nom de Donatien était vingt fois écrit. $M$. de La Rebelière vit tout cela par-dessus l'épaule de sa femme à la lueur d'une lampe qui s'éteignait.

Pale, les yeux hagards, les dents serrées, il chercha instinctivement à son côté le couteau qu'il avait quitté en se déshabillant ; puis l'idée d'une autre vengeance lui vint subitement (Les Epaves 72)

Monsier de La Rebelière avenges his humiliation by leading a raid on Donatien's estate, demanding his right as a white colon to sell any black person who cannot provide proof of manumission. As he anticipates, Donatien is legally classified as un épave, a former slave without proof of manumission from a master. He immediately arrests Donatien, has him beaten and returns him to the de La Rebelière plantation.

The actions of Monsieur de La Rebelière are very significant when analyzed in the light of the Family Romance of colonial France. Donatien's capture and imprisonment places him in the position of a child in regards to the de La Rebelière family, therefore giving the father the right to protect his wife from any romantic connection to his "son." The process of imprisonment is characteristic of Romantic representations of the power struggle between white and black masculinity: "The implements of power include the theater of war and the prison cell, the later posited as an echo of the institution of slavery" (Saint-Aubin 18). Indeed he imprisons Donatien on his own property to further enforce his paternal authority over Donatien. 
The story of Donatien's imprisonment horrifies Eléonore and Cécile. The elder Creole woman correctly deduces that her husband has somehow discovered her passions for Donatien:

Elle comprenait que quelque délatation, quelque funeste hasard avait appris à son mari ses relations avec le mulâtre, et qu'il avait deviné la passion qu'elle portait cachée si profondément dans son cœur ; mais elle savait bien qu'il tuerait Donatien sous ses yeux, sans jamais lui reprocher le motif de cette affreuse vengeance. (Les Epaves 79)

Eléonore's emotionally marriage is a type of slavery, one that she rightly fears to leave. Cécile, however, finds herself in a position to act. During the time that Monsieur de La Rebelière conducted his raid to capture Donatien, Cécile has reached the age of an adult and is legally "emancipated." She responds to Monsieur's account of Donatien's imprisonment by offering to purchase him for herself:

- Puisqu'il est à vendre, j'ai envie de l'acheter, dit Cécile après un moment de réflexion, et comme si elle n'eut pas attaché à cette proposition une grande importance; monsieur, vous pourrez épargner ainsi les frais d'un encan. C'est décidé, cet épave m'appartiendra.

- Ma belle pupille, répliqua vivement $M$. de la Rebelière, cela ne se peut pas ; je m'y oppose.

- $\quad$ Oh ! dit-elle, en essayant de rire, se je le voulais bien, pourtant ? Je suis majeure à présent. Vous ne pouvez pas me dire : Je m'y oppose.

- Allons, vous plaisantez toujours.

- Mais non, je ne plaisante pas, je vous jure.

- Serieusement, il ne faut pas songer à avoir ce mulatre; qu'en feriez-vous? C'est un mauvais drôle: vous êtes trop bonne pour pouvoir le dompter. II m'a insulté, menacé ; je veux le punir. C'est moi qui l'achèterai.

M. de La Rebelière se tourna vers sa femme et ajouta en la regardant: J'ai juré qu'il mourrait sous le fouet d'un commandeur! (Les Epaves 78)

Raised in France, Cécile has always had compassion for the slaves that labor under Monsieur de La Rebelière. In the above text, Cécile's romantic passion for Donatien intensifies her liberal views on race, and gives her the courage to defy the wishes of 
Monsieur de La Rebelière. In this manner Cécile begins to defy the man who exercised a form of paternal authority over her only the day before. When she learns of Monsieur de La Rebelière's plans to have Donatien killed, she determines to save him. Only an "emancipated" woman was able to do this:

What is particularly important from our point of view is that the Blanche / Noir couple traditionally encapsulates the more radically scandalous transgression of perceived power relationships, with emancipation involved for both parties, thereby reversing notions of dominance by White and male over Black and female, a precedence which is further problematized in the white female's relationship with the black male (Little 4)

Cécile learns that the keys to Donatien's cell are in Monsieur de La Rebelière's bedroom. By placing the keys to Donatien's cell in the master bedroom, Mme de Reybaud links two types of white masculine power: the power to enslave Donatien with the power to "enslave" and abuse Eléonore. Cécile manages to steal the keys and goes to visit Donatien. Seeing him beaten and chained, she again resolves to save him: "Elle jura dans son cœur de protéger ce malheureux, de se mettre entre lui et son bourreau, de l'arracher aux mains impitoyables qui l'avaient ainsi déchiré. (Les Epaves 82)

In a hasty, whispered conversation, Cécile discovers that Monsieur de La Rebelière has arrested Donatien illegally. Having been raised in France during the eighteenth century, Donatien claims the right of a free Frenchman: "Mais je suis libre, libre de droit, par ce beau privilège qui donne la liberté à tous ceux qui ont touché la terre de France, où nul n'est esclave!" (Les Epaves 83) This law of emancipation, applied only sporadically since the Bourbon Restoration, was of particular interest to Mme de Reybaud's reading audience due to the increasing population of free gens de couleur in the 1830 's: 
... Martinique's Creoles [also] tried to prevent the island's free mixed-race citizens from taking advantage of their rights as French citizens. Between 1831 and 1835, Martinique's white population declined from 9,362 to 9,000; due to recent legislation facilitating manumission, however, the gens de couleur population more than doubled from 14,055 to 29,955 , and the enslaved population decreased from 86,499 to 78, 076 . Although nearly 30,000 free mixed-race Martinicans now technically enjoyed full civil and political rights, approximately 20,000 of them had earned their freedom in the last ten years. (Schloss 165)

Cécile informs Donatien of her plans to purchase him at auction. Alone in their cell, Donatien and Cécile realize their devotion for each other, stopping barely short of confessing romantic passion. Before she leaves, Cécile hears the wind of an arriving storm. By the time she leaves Donatien, Cécile finds herself braving a terrifying storm: L'orage allait éclater; les éclairs lui montraient le chemin. Elle tremblait, maintenant qu'elle avait accompli cette tentative hardie, et elle rentra dans la chambre de M. de La Rebelière avec plus de frayeur qu'elle n'y était venue trois quarts d'heure auparavant. . . . Cécile posa les clés sur la table à côté de la veilleuse. Au même moment un coup de tonnerre ébranla la maison. (Les Epaves 84)

The arrival of the storm announces Cécile's willingness to challenge her former guardian, the final clap of thunder seeming to announce Cécile's destiny as the woman who will undo the prerogatives of the Symbolic Order.

Before his auction, Cécile discovers that Donatien belonged to the house of Rethel, whose estate she serindipidoulsly inherited when she became a legal adult. The raid on Donatien's estate, conducted the very day of her emancipation, was therefore a violation of Cécile's rights as a legal, land-holding adult. She rushes to the auction, commanding that Donantien be removed from sale on the grounds that she already owns him. Before Cécile's arrival, however, Donatien insults Monsieur de La Rebelière by publically exposing his common heritage and timid efforts to concel his true 
parentage. Monsieur de La Rebelière was, despite all outward appearances, the son of an indentured servant:

Vous, fils d'un engagé qui a vécu trois ans sous le fouet d'un commandeur; vous qui, devenu riche à force d'iniquités avez renié jusque au nom de votre père : il s'appelait Rebel le tonnelier, vous êtes M. de La Rebelière. Etrange noblesse dont tout le monde ici peut vérifier les titres! Mon origine vaut la vôtre, je pense ; il est plus honorable d'être esclave comme moi que noble comme vous, monsieur ! (Les Epaves 53)

Enraged, M. de La Rebelière strikes Donatien with his walking cane. Younger and stronger, Donatien disarms de La Rebelière and breaks the cane that he used to strike him. Humiliated again by Donatien, M. de la Rebelière resorts to Le Code Noir to insist on Donatien receiving twenty-nine lashes for insulting him in public. Having rescued Donatien from being sold, Cécile now rescues him from public abuse and humiliation by marrying him:

Cécile se mit devant Donatien; elle était pâle, mais elle avait le front haut et le regard assuré. Cette terrible situation lui inspira sur-le-champ une de ces résolutions qu'il faut plus de courage pour déclarer que pour mettre à l'exécution, et se tournant vers $\mathrm{M}$. de La Rebelière, elle dit d'un accent bref et ferme :

- Non, vous ne toucherez pas à cet homme ; il n'est plus esclave ; dès ce moment il est libre, car je déclare ici, moi, Cécile de Kerben, que je l'épouse .. . Lisez, lisez l'article du Code Noir : Tout esclave qui épouse une femme libre est libre de droit (Les Epaves 101)

Cécile de Kerben's public marriage proposal to Donatien was the ultimate emancipation for both le mulâtre and herself. By marrying Donatien, she procures liberty for un épave without participating in the slave market by purchasing him. In the process, she defies the Symbolic Order by initiating, rather than responding to, an interracial marriage.

In Les Epaves, Mme de Reybaud uses the body of le mulâtre as the site upon which two women place their romantic passions. As a married, uneducated woman, Eléonore 
de Rebelière can only suffer from her romantic passions; even if she were to leave the emotional and physical abuse of her husband, she does not have the education or the financial means to live independently. This is not the case with Cécile de Kervens; she was raised outside the prejudices of French Caribbean and had financial means. Her decision to marry a mixed-race male represented the very domestic arrangement that evoked such anxiety for the white creole population in the 1830 's: the wealthy white metropolitan or Creole female who marries a mulatto male.

Defiance of the Symbolic Order by proposal to a mulatto would be a theme Alexandre Dumas used as well. Like Mme de Charles Reybaud, I argue that Dumas made use of the tropical storm as a paternal metaphor in his novel Georges.

\section{Surviving The Storm: Interracial Romance in Georges}

Mauritius was well known to the French reading public as the setting of the wildly popular Paul et Virginie. The actual history of the island and metropolitan France, however, is relatively short. An island with no indigenous population, Mauritius was first settled by the Dutch in 1638 and then abandoned in 1710 . The colony came under French rule in 1715 and renamed l'Isle de France when Guilliome Dufresne D'Arsel landed on the island en route to India. The Isle de France became a francophone colony as French colonists increased sugar production on the island and imported slaves from Africa for the necessary manpower to harvest the sugar. During the Napoleonic Wars, France used this island as a naval base to attack British ships, which motivated Britain to conquer the island. The colony came under British control in 1810 and never again returned to France. A very diverse colony by the early nineteenth century, Mauritius 
was home to individuals from Europe and, due to immigration from India and China, Asia was well. Molly Kreuger-Enz comments on the importance of Isle de France on Dumas's novel in her article "The Mulatto as Island and the Island as Mulatto in Alexandre Dumas's 'Georges'”:

The Isle de France is an appropriate choice of setting for the tensions of identity represented in Dumas's novel, as it is a cultural crossroads situated next to continental Africa, colonized by Europeans, and inhabited by many Asians . . . This island is a place of diverse racial and cultural mixings, and is separated geographically from the rest of the world while at the same time linked to Europe via commerce and politics. For Dumas, the island's exoticism was heightened by its earlier use in Bernadin de Saint-Pierre's novel Paul et Virginie (1788). (385-386)

When Alexandre Dumas, himself a bi-racial writer whose life was affected by the realities of racism in metropolitan France, chose to set his novel in Mauritius, he chose a colony that was very diverse ethnically and linguistically. At the same time, Dumas chose a locale firmly established in the French Romantic imagination as the site of a tragic love story. What may have been even more interesting to Dumas was the fact that Britain had abolished slavery in 1835. By the time Georges (the only novel in which Alexandre Dumas deals explicitly with the topic of race) was published, slavery had been abolished on Mauritius for eight years. Therefore, Mauritius was quite possibly the perfect setting for a story of a blanche / noir romance.

The youngest son of a wealthy mulatto plantation owner, Georges Munier was born into the colonial aristocracy of wealth on the Isle de France. However, the Munier family endured outrageous racial discrimination. When his sons dare to defy the system of racial hierarchy, Pierre Munier sends them to France to complete their education in safety. Georges' sojourn in France was in several ways preparation to undertake his 
battle against the racial prejudices against les hommes de couleur on Mauritius. An educated, cultured, wealthy and handsome young man, Georges Munier has no problem attracting the attention of several young women in France. The Blanche / Noir romance in Alexandre Dumas' text, therefore, seems to take on a different meaning based on geographical location and, like Mme de Reybaud's Les Epaves, seems to projecting racial prejudices onto the European colonial world.

Soon after Georges returns to Mauritius he meets Sara de Malmédie, Monsieur de Malmédie's niece. Sara notices his looks, natural charm and intelligence as Georges serves as an interpreter to assist Sara in her attempt to purchase a fan from an Asian merchant named Miko-Miko. Georges' use of Chinese, which he learned from the Asian servant who kept the Munier household after the death of his mother, amazes Sara de Malmédie, her British governess Henriette and the elderly black servant who accompany her.

The initial attraction that Sara feels for Georges also seems to mark the beginnings of Sara's transition from adolescent girl to young woman. Georges Munier's charm disarms Sara to the point that she is initially uncomfortable discussing it with her governess (151). Sara's governess fulfills a maternal role in Sara's life (indicated by Sara's calling her "ma mie Henriette"), and despite her governess's efforts to prepare Sara for "civilized" life of the aristocracy, Sara prefers to live close to nature and obey her heart and her instincts:

Je sais que les femmes d'Europe, celles qu'on appelle les femmes comme il faut, du moins, ont trouvé un admirable milieu entre la franchise et la dissimulation ... . je ne suis pas une femme civilisée, je suis une petite sauvage, élevée au milieu des grands bois et au bord des grandes rivières. Si ce que je vois me plait, je le désire, et, si je le désire, 
je le veux ... Quand j'ai demandé, on m'a donné presque toujours; et, quand on m'a refusé par hasard, j'ai pris, et on m'a laissé prendre. (Georges 154)

Dumas's portrayal of Sara de Malmedie, an aristocrat by birth but raised on Mauritius, offers a favorable comparison to Virginie. The comparison becomes even more vivid when Sara spends an afternoon bathing. Watching Sara from the shore, Henriette and Sara's servant are terrified as they see a large shark swim silently towards the young girl. Sara initially tries to swim to the shore, but soon sees that it is useless:

Elle jeta un dernier coup d'œil vers le rivage qu'elle n'avait plus de temps de gagner. Alors elle comprit qu'il était inutile de disputer plus longtemps une vie condamnée, elle leva les yeux au ciel, joignit les mains hors de l'eau, implorant Dieu, qui seul pouvait la secourir. (Georges 173)

Comparing the above quote to the scene of Virginie's death reveals a certain degree of inter-textuality: "Virginie, voyant la mort inévitable, posa une main sur ses habits, l'autre sur son Coeur, et levant en haut des yeux sereins, parut un ange qui prend son vol vers les cieux." (Paul et Virginie 224 - 225). Unlike Virginie, Sara doesn't perish; Georges Munier, an expert marksman, suddenly appears and manages to kill the shark from the shore with a double-barreled rifle (173). I suggest that the text describing Sara's near death experience establishes her as "the Virginie who lived," the female aristocrat raised on Mauritius who, despite being well acquainted with European mores of feminine behavior, will still chose to follow her heart and defy societal norms.

The social norms become apparent the next evening at Lord Williams Murrey's ball. Forbidden to dance with Georges Munier and aware of the racial prejudices behind it, Sara refuses to dance with anyone and demands to be escorted home. In the absence of a biological father, Sara de Malmédie has heretofore submitted to the paternal role of 
her uncle, whose name she also shares. Le non-du père (in Alexandre Dumas's text, also le nom-du-père) inscribes Sara de Malmédie within a social order which forbids her romantic interest in Georges Munier.

The intertextuality between the characters of Virginie de La Tour and Sara de Malmédie is joined by references to the tropical storm itself. Soon after Lord William Murrey's ball, Georges Munier and Pierre Munier are reunited with Georges' elder brother Jacques Munier. Georges declares his love for Sara de Malmédie and his intentions to marry her to his father and brother. All three men understand that the colony's racial hierarchy will affect the outcome of Georges' decision to pursue Sara. Jacques Munier is in full support of Georges' love for Sara, although he would not defy the miscegenation taboo for personal reasons: "Quant à Jacques, il comprenait parfaitement que Georges aimât une femme blanche, quoique, pour mille raisons qu'il déduisait à merveille, il préférât de beaucoup les femmes noires." (Georges 238). Pierre Munier, however, is terrified by Georges' intention to pursue and marry Sara de Malmedie. Once again, the image of the tropical storm appears (initially as a figure of speech) when le mulâtre declares his love for la blanche and the possibility of le couple domino defies the Symbolic Order:

A ce récit, Pierre Munier frémit de tous ses membres; Georges, mulâtre, fils de mulâtre, aimait une blanche, et déclarait, en avouant son amour, que cette femme lui appartiendrait. C'était une audace inouïe et sans exemple aux colonies, qu'un pareil orgueil ; et à son avis, cet orgueil devait attirer sur celui dans le cœur duquel il s'était allumé, toutes les douleurs de la terre et toute la colère du ciel (Georges 238 emphasis mine)

Georges Munier wastes no time in pursuing Sara de Malmédie, and employs the assistance of the Asian merchant Miko-Miko to deliver a message to the Malmédie 
estate. Posing as a door to door merchant, Miko-Miko was able to deliver a card to Sara from Georges while simultaneously taking note of the entrances and exits to the Malmédie estate. When Miko-Miko returns to the Munier household, he draws a picture for Georges outlining the plans of the Malmédie household. After finding a pavilion where he could meet Sara undetected, Georges sends Miko-Miko back with a letter to Sara declaring his love for her. The letter also plainly states the difficulties that life with him would bring (Georges 247). Georges' letter requests that Sara meet him at ten o'clock that evening to tell him her response.

As the evening advances, a tropical storm begins to brew over the island. Jacques Munier leaves his family to secure his ship, and Georges and his father ride back to the Munier estate. The storm terrifies Pierre Munier, but seems to energize Georges:

Aussi, Pierre Munier était-il doublement effrayé de voir Jacques partir et Georges prêt à partir, mais, toujours faible devant une force morale quelconque, le pauvre père avait plié, et, tout en frémissant aux mugissements du vent, tout en palissant aux grondements de la foudre, tout en tressaillant à chaque éclair, il n'essayait même plus de retenir Georges près de lui. Quant au jeune homme, on eut dit qu'il grandissant à chaque minute qui le rapprochait du danger ; tout au contraire de son père, à chaque bruit menaçant, il relevait la tête : à chaque éclair, il souriait ; lui qui avait jusqu'alors essayé de toutes les luttes humaines, on eut dit qu'il lui tardait, comme à Don Juan, de lutter avec Dieu. (Georges 251)

The storm that Georges Munier braves to see Sara provides the background in which Sara reads his letter. Sara's decision to accept Georges in greatly influenced by his decision to brave a hurricane in order to see her:

Alors elle se releva tout à coup ; sa résolution était prise. L'homme qui, au milieu de pareils dangers, quand les plus braves tremblaient dans leurs maisons, venait à elle, traversant les forets déracinées, les torrents grossis, les précipices béants, et tout cela pour lui dire : " Je vous aime, Sara ! m'aimez-vous ? " cet homme était vraiment digne d'elle. (Georges 254) 
Sara's attraction for Georges Munier also announces the awakening of her sexuality as an adult woman. The toy that Georges uses to disguise the note that confesses his love for Sara is designed to appeal to her childlike passions (Georges 245). The decision to accept his love for her, and to give her love to him, is accompanied by a strange sensation that she cannot explain. There is an interesting intertextuality between the passage in Georges and the awakening of Virginie's sexuality in Paul et Virginie:

Elle pense à l'amitié de Paul, plus douce que les parfums, plus pure que l'eau des fontaines, plus forte que les palmiers unis, et elle soupire. Elle songe à la nuit, à la solitude, et un feu dévorant la saisit. (Paul et Virginie 160 emphasis mine)

Virginie's awakening and forbidden sexual attraction for Paul is as unknown to her as the sensation that grips Sara Malmédie, also awakened by the thoughts of a man forbidden to her : "Une sensation inconnue, rapide, dévorante, courut par tout son corps ..." (Georges 255).

Sara's torrent of emotions is interrupted by the arrival of Georges Munier. The two confess their love for each other, and Georges swears to defy any obstacle that would keep them apart. This exchange is followed by a violent report of thunder:

A ces mots, Georges appuya ses lèvres sur celles de la jeune fille ; et, craignant sans doute de ne plus être maitre de lui-même en face de tant d'amour, de jeunesse et de beauté, il s'élança dans le cabinet voisin, dont la fenêtre, comme celle du pavillon, donnait sur le chantier, et disparut. En ce moment, un coup d tonnerre si violent retentit, que Sara tomba à genoux. Presque aussitôt, la porte du pavillon s'ouvrit, et M. de Malmedie et Henri entrèrent. (Georges 256)

The paternal metaphor of the hurricane relents as the paternal figure of Monsieur de Malmédie appears. Already engaged to her cousin Henri, Sara de Malmédie must defy the Symbolic Order twice by refusing to marry Henri and entering an interracial marriage. 
When Georges Munier fails to obtain permission to marry Sara, he publically insults Henri de Malmédie and agrees to lead a slave revolt (Chapter Five). His defiance of the Symbolic Order complete, Georges requires the same of Sara. Le non-du-père of Mauritius under British colonization is represented in the text by Lord Williams Murrey, who is willing to "give" Sara to Georges in exchange for Georges overlooking the insults suffered at the hands of the Malmedie family. This offer is unacceptable to Georges, who requires that Sara give herself to him of her own free will:

Si mademoiselle Sara m'aime, mademoiselle Sara est libre, maîtresse de sa main, maîtresse de sa fortune, c'est à elle de se grandir encore à mes propres yeux en descendant jusqu'à moi, et non à moi de m'abaisser aux siens en essayant de monter jusqu'à elle.

- Oh ! monsieur Georges, s'écria Sara, vous savez bien ... .

- Oui, je sais, dit Georges, que vous êtes une noble jeune fille, un cœur dévoué, une âme pure. Je sais que vous viendrez à moi, Sara, malgré tous les obstacles, tous les empêchements, tous les préjugés. (Georges 329)

The above text shows that Georges expects Sara to refuse le non-du-père that he has already refused: the requirement that Georges renounce his battle against color prejudice.

Sara de Malmédie does defy the colonial non-du-père towards the end of Dumas' novel. Wounded, imprisoned, and sentenced to execution, Georges Munier waits in his cell wondering if Sara would have chosen him if she could. Sara's refusal of le non-dupère takes place quite literally in the midst of society. Dressed in the black garb of a widow, Sara de Malmédie awaits Georges in front of the church that he must pass on the way to the scaffold. Her determination to prove her love for Georges has emboldened her to exercise a measure of authority over the assembled crowd: 
Sara étendit la main d'un mouvement lent et solennel; il se fit un grand silence dans toute cette foule.

Ecoutez, dit-elle, sur le seuil de l'église où il entre, sur le seuil du tombeau où il est près d'entrer, à la face de Dieu et des hommes, je vous prends tous à témoin que moi, Sara de Malmédie, je viens demander à M. Georges Munier s'il veut bien me prendre pour épouse. (Georges 414)

The representation of le mulâtre involved in an interracial relationship evokes two specific types of anxiety: the black male capable of winning the affection of a white female and the emancipation of the white woman who lives under a racist and patriarchal society. Interracial romance with a male mulatto seems to consistently feature a white female. As Leon Francis Hoffman notes in Le Nègre Romantique, the male mulatto who chooses a romance with a black female is unknown in French Romantic literature. As a result, le mulâtre is the harbinger of the end of racism and sexism in these two novels that connect race and gender. By surviving the metaphorical storm, le mulâtre and the white woman challenge "le non du père" by defying the taboo of blanche / noir romance in French literature. As such, le mulâtre serves as a major trope of transition in the French literary imagination.

The various representations of le mulâtre that I have examined in Chapter Three though Chapter Six of this dissertation trace an evolution from the gothic villain to the romantic hero. The male mulatto in interracial romance is the last racial taboo explored before the disappearance of le mulatre in the middle of the nineteenth century. In the next chapter, I explain the sudden disappearance of le mulâtre from metropolitan French literature and how the image of le mulâtre and his demand for recognition and agency forms a bridge from la littérature négrophile and negritude. 


\section{Conclusion: Calming the Anxiety: Le Mulâtre Becomes La Bourgeoisie de Couleur}

I have argued throughout this dissertation that Nancy Bentley's observations of the mulatto in American antebellum fiction, and the "attendant anxiety" that he seems to evoke (Bentley 503), can be applied to French Romantic literature. In Chapters Three through Six of this dissertation, I have explored various representations of this anxiety: memories of Saint-Domingue, Oedipal revolt, interracial romance, etc. This dissertation has focused on the period of time from the early 1820's to 1848, during which period novels that featured mixed-race characters were largely authored by white writers who portrayed the mulatto as "a romantic and denigrated character" (Maignon-Claverie 48). Images of le mulâtre in French metropolitan literature are extremely rare after the advent of the Third Republic. The sudden disappearance of mixed-race males from the French literary imagination is as interesting as the anxiety they evoked. Jennifer Yee calls attention to this curious disappearance of le mulatre along with other literary representations of métissage in her article "Neither Flesh nor Fowl: Métissage in fin-desiècle French Colonial Fiction:"

What we have observed is the "étouffement" of the hybrid child in French novels under the early years of the Third Republic... The theme of métissage could have had a place in the fashionable literature of dégenerence, yet it never took on such a role. On the contrary, the Third Republic seems to have had great difficulties in acknowledging the presence of the half-breed child, and the great majority of colonial novels ignore its presence... (Yee 55)

The disappearance of the mulatto and other métis images is rather surprising considering that these years were the height of French colonial expansion. In her book Reproducing the French Race: Immigration, Intimacy, and Embodiment in the Early Twentieth Century, Elisa Camiscioli notes that interracial couples were "either tolerated 
or actively encouraged" during the earliest phases of colonization of Africa and Asia

(79). The presence of a large mixed-race population throughout France's colonies and their absence in French metropolitan literature is both strangely reminiscent of the years prior to the Bourbon Restoration and puzzling in light of the fact that these same images appeared in the years between 1806 and 1848.

This étouffement, I argue, is the result of le mulâtre's new place in the French cultural imagination: the colonial subject. In the years following the abolition of slavery, certain black individuals throughout France's colonies began distinguishing themselves from other black individuals on the basis of their lighter skin color and ability to mimic the French culture (Lewis 11). France's assimilationist policies characteristic of the Third Republic, particularly the French colonial system of education which largely ignored France's history of race-based slavery, resulted in a population known as la bourgeoisie de couleur. It is this perfectly assimilated, colored citizen of France that French Martinican students sternly renounced in Légitime Défense (1932). Inspired by the surrealist movement and dedicated to the principles of Marxism-Leninism sweeping Europe in the interwar period, these students targeted the black bourgeoisie throughout the French Caribbean as the tool of black oppression:

Issus de la bourgeoisie de couleur française, qui est une des choses les plus tristes du globe, nous déclarons - et nous ne reviendrons pas sur cette déclaration - face à tous les cadavres administratifs, gouvernementaux, parlementaires, industriels, commerçants, etc., que nous entendons traitres à cette classe, aller aussi loin que possible dans la voie de la trahison (2).

In this concluding chapter, I trace the historical process by which le mulâtre evolves from a romantic literary character to find a place in France's colonial imagination. It is in 
this process that the threatening character of le mulâtre is "tamed" in the French imagination. However, it is this overly docile, assimilated character that will evoke the rebellion of the negritude writers in their search for a black identity.

The quest for identity that motivated the negritude writers was not possible until they were motivated by a rediscovery and interest in African history. Significantly, the mulatre's quest for identity was a part of his desire to reclaim a history that was his: that of France's revolutionary history and colonial empire. I argue that the disappearance of le mulâtre is a result of three literary and historical events: the decline of Romanticism, the rise of scientific racism and the assimilationist policies of the Third Republic.

\section{From Romanticism to Social Romanticism}

Romanticism, with its gothic and exotic images, interest in historical events and emphasis on introspection was the perfect literary expression for representations of the mixed-race individual (Hoffmann 329). Le mulâtre was most common in French literature from the mid-1820's to the mid-1840's. As I have shown in Chapter Three, le mulâtre in the 1820's was demonized due to his association with memories of the SaintDomingue revoltuion. Le mulâtre more closely resembled the traditional romantic hero (Alexandre Dumas' Georges, Les Epaves by Mme Charles de Reybaud and Le Mulâtre by Victor Séjour) in the 1830's and 1840's, the height of the Romantic movement. In her book Trauma and Its Representations: The Social Life of Mimesis in Post-Revolutionary France, Deborah Jenson notes the increase in mixed-race literary characters during the years between 1830 and 1848 (147). The loss of interest in le mulâtre can be explained 
in part by the decline of romanticism in the mid-nineteenth century. The July Monarchy may have been more liberal in their attitudes towards racial relations, but it was also a time of domestic unrest and class struggle. Riots in Lyon in 1831 and 1832 demonstrated the desperation experienced by the working class. These were the difficulties that French novelists chose to write about, since traditional romanticism no longer seemed to interest the French reading public:

Romanticism was increasingly out of tune with the spirit of the age as the century advanced; the new sober mood and materialistic aims of the industrial era had little sympathy for obscure flights of individual imagination and no use whatsoever for an art that 'bakes no bread' ... The disciplined objectivity of Realism came to replace - at least for a time - the autonomous imagination of Romanticism. (Furst 50)

Lilian Furst's observation of realism replacing romanticism might be more accurately thought of as an evolution from traditional romanticism (characterized by the mal of the individual romantic hero and le vague des passions) to a social romanticism which focused more on sentimentality evoked by the plight of the working class. In his book Social Romanticism in France 1830 - 1848, David Evans studies France's problematic transition from an agricultural to industrial country. The social unrest resulted in a "working class literature" that sought to reconcile the divisions and individuality valued by traditional romanticism.

Romantic socialism held a special place for le mulâtre. As I have shown in Chapter Six of this dissertation, the 1830's witnessed a shift to more positive representations of le mulatre, even going so far as to explore interracial romances between le mulâtre and white women. These successful interracial romances portray le mulâtre as the member of the black race that could reconcile racial hostilities in French colonies. One of the 
most notable indications of this trend was the pamphlet Lettres sur la race noir et la race blanche, published in 1839 by Gustave d'Eichtal and Thomas Ismayl Urbain. Gustave d'Eichtal was a pioneer in the science of race and the secretary of the Société ethnologique, a group committed to the study of the relationship between race and the social characteristics of various peoples. Anticipating the abolition of slavery and eventually a large black electorate ${ }^{47}$ members of the Société ethnologique sought to pre-empt the tensions between races by portraying le mulâtre in a positive light:

Romantic socialism was a movement was devoted to rescuing the organic connections that bind mankind together from what romantics saw as the destructive rationalism of the Enlightenment and the social upheaval of the revolutionary decades, both in France and in the overseas empire, Haiti in particular ... Romantic socialists used metaphorical, figurative, and gendered language to describe the unity they sought. One of the most creative examples of this expressive mode is the mulatto discussed by d'Eichtal and Urbain. Resolving embodied differences, whether between the sexes or between the races, was part of the vernacular of social reconciliation employed by romantic socialists, and the mulatto was expressed in that vernacular (Andrews 246)

D'Eichtal and Urbain's work depended greatly on the gendering of races. The white race was the "masculine" white race, predisposed to reason, government and scientific progress. The black race was the "feminine" race, predisposed to emotion, passion and the arts. The mulatto was portrayed as a fusion of these two racial characteristics and proof that the two races could exist harmoniously:

The central precept of the letters is an argument for the symbolic and sociological potential of interracial marriage and of its metis to renew a troubled humanity, hardly a mainstream idea in the early nineteenth century. The mulatto is depicted in their letters as a harbinger of hope, a panacea for that which ails contemporary society, and as a symbol of the reconciliation of conflict and division in the human family (Andrews 241)

The idea that the mulatto embodied not only a mixed phenotype but mixed personality traits of the gendered races quickly gained ascendency in the French cultural 
imagination. This resulted in the mulatto having a unique place in the rising tide of scientific racism during the third and fourth decades of nineteenth-century France. The abolition of slavery in 1848 , which coincided with the decrease of traditional and social romanticism, resulted in a rapid increase in theories of polygenism.

By 1850 scientific racism and polygenism had gained the upper hand in France. The belief in polygenism despite decades of interaction with viable, intelligent and cultured mixed-race individuals is admittedly difficult to explain. Paul Broca, the founder of the Société d'anthropologie, re-introduced eighteenth-century theories of métissage that claimed children of biracial unions were stunted both morally and physically. Broca was also responsible for developing the theory of "unilateral hybridity," (1859) which stated that the only combination of gender and race capable of producing children was the white male and the black female. Broca's theory of unilateral hybridity did not garner much of a following, but ideas on polygenism remained and affected the readiness of the French public to accept literature which features le mulâtre. William Cohen observes this change in the French literary imagination:

While polygenic convictions were expressed in specialized works of biology, they were also echoed in popular opinion, as can be seen in the literature of the time in regard to sexual contact between the black and white races. Novels seemed to assert the impossibility of successful union between the two races. Interracial sex was presented as the violation of the distance between the two species; the failure of such unions was proof of the unbridgeable biological gap. (Cohen 234-235)

This renewed pessimism concerning métissage seemed to be evoked by the extensive colonization of Africa. Jennifer Yee observes the difference between métissage in France's Antillean colonies and métissage in continental Africa: 
In the younger African colonies it was comparatively easy to reject the possibility of cross-breeding, while in the old island possessions which dated from France's first colonial period, racial mixing presented itself as a fait accompli. In other words, métissage is something which happened in the past, but which is presented as doomed in the more hypocritical present. (54)

The image of le mulâtre seemed to have a unique geopolitical significance that was changing in the mid-nineteenth century and, depending on the country or continent of origin, was either welcomed as a part of or perceived as a threat to the French nation. Despite the abolition of slavery, colonial rule was nonetheless based on "a clear demarcation between whiteness and color, civilization and savagery, ruler and ruled" (Camiscioli 80). France needed a new conception of the bi-racial children being born in its more recent colonies and who were seen as a threat to the racial purity of France.

The document traditionally viewed as the synthesis of the racial climate in France during the latter half of the nineteenth century was Arthur de Gobineau's Essai sur I'inégalité des races humaines, published between 1853 and 1855. In his essay, Gobineau traced the fall of great civilizations to their intermingling with other races. Gobineau's conception of "race" was not limited to biological race; he considered the difference between classes to be a difference in race as well. Gobineau's pessimistic view of racial contact anticipated an eventual mixing of races that would result in the purity of the Aryan race being lost and, consequently, the grandeur of European civilization would gradually decrease. However, the mulatto did have a place in this racially hybrid, mediocre future: the colonies. Unlike the black (non-mulatto) inhabitants of France's colonies, le mulâtre had great potential for productive citizenship in what Gobineau saw as the colonial "state": 
L'Etat est partagé en deux factions, que ne séparent pas des incompatibilités de doctrines, mais de peaux: les mulâtres se tiennent d'un cote, les nègres de l'autre. Aux mulâtres appartient, sans aucun doute, plus d'intelligence, un esprit plus ouvert à la conception. Je l'ai déjà fait remarquer pour les Dominicains : le sang européen a modifié la nature africaine, et ces hommes pourraient, fondus dans une masse blanche, et avec de bons modèles constamment sous les yeux devenir ailleurs citoyens utiles (Essai 186)

According to Gobineau's essay, the potential for mulatto population to contribute to the French society greatly surpassed that of the white French peasant, who would marry within his own race and class and quickly stagnate in his potential for progress. Le mulâtre, on the other hand, could continue to "improve" as long as they were carefully supervised and allowed to mix with the white race. Gobineau's essays, building on the tradition that d'Eichtal and Urbain started in the late 1830's and coupled with the rise of polygenism, redefined the mulatto and "tamed" the anxiety he produced by and placing him as a colonial citizen and the ultimate carrier of French culture.

Gobineau's work, published for the second time in 1884, seemed to have had a strong influence on French colonial policy. The Third Republic embraced assimilationist stances in its colonies, particularly in the realm of education. Education for wealthy children of color had existed in France's colonies since the 1820's, but a system of education did not exist for black (non-mulatto) children, either enslaved or free, until 1882. (Felostrat 31) The center for colonial education for French colonies from the late nineteenth century to the mid-twentieth century was Bordeaux, a major port of the Atlantic slave trade. The cornerstone of the curriculum planned for France's colonies was Latin, French and French history. French history ignored France's past as a major European power financed by the Atlantic slave trade and presented France's colonial history as "une mission civilisatrice." French became the language of the black cultural 
elite, and French Romantic literature served as the model for literary studies throughout the colonies. By erasing the cultural memory of slavery, France was able to assimilate the mixed-race population into la bourgeoisie de couleur. These culturally assimilated individuals of various racial heritages took great pride in their French heritage and citizenship; consequently, they posed no threat to the preeminence of French culture over African or Antillean cultures.

Colonial education, for most students seeking professions other than elementary education or positions as colonial fonctionaires, culminated in travel to France: "This trip to the mother country climaxed the elitist course in the assimilationist educational system. Going to France was intended to immerse the colonial student in the bosom of French culture and then return them as a model to the colonies." (Felostrat 32) It was in France during the interwar period, however, that children of la bourgeoisie de couleur were exposed to the surrealism that presented an alternative to the now out-dated French Romantic model of literature. Furthermore, they were exposed to the MarxismLeninism that would provide a different political paradigm to observe the existence of their fathers: la bourgeoisie de couleur, having lost all sense of black identity in an effort to assimilate to France, had become a tool of oppression for the black proletariat in France's colonies. A rejection of cultural assimilation and the search for a black identity were the bedrock of the negritude movement. Influenced by their understanding of black American writers from the Harlem Renaissance, the negritude writers created a literature that explored themes of alienation, race, revolt, the search for identity and exile (Sharpley-Whiting 12, Cunningham 765 and Nwaegbe 11). 
The negritude movement was, initially, a reaction against the loss of black identity as a result of French cultural assimilation. Therefore, negritude dealt with themes of alienation, revolt and the search for identity, and the question for personal agency. These themes, embodied in black characters, were first explored in French Romanticism. Nineteenth-century romantic representations of le mulâtre, his search for recognition and demand of agency, anticipated how negritude writers would explore these same literary themes.

Having traced the history of the mixed-race image from the French literary imagination to the cultural imagination of the writers of Légitime Défense, I will conclude this chapter by showing how the search for blackness and the attendant themes of alienation, fragmentation, and loneliness are anticipated in the representations of le mulâtre in Romanticism.

The exploration of le mulâtre as a unique black Romantic character is made possible by the role mixed-race individuals played in French history. As children of the assimilated black classes, negritude writers themselves were at a loss to fully explore the themes of alienation, black identity, fragmentation and racial marginalization. This changed when they were inspired by a rediscovery of African history and civilization. The literary theme of recognition, according to Ethan Kleinberg, is predicated on history. The exploration of black person as a complete individual, capable of confrontation with whiteness, was severely limited as long as Africa was excluded from the Hegelian conception of history:

The black, the colonized, is denied history ... He is thrown into a world of symbols and meanings that are not his own. Therefore at the moment of initial confirmation prior to 
the possibility of a struggle for recognition there is an epistemological assertion ... From the very moment that the white colonizer sets foot onto "his" colonial territory, he has determined the inhabitants as less than he, unequal and unworthy of his human Desire. This "fact" is reinforced by the color of the inhabitant's skin and the European understanding of what this means. The black is redefined in European terms and as such is excluded from human potentiality (Kleinberg 124)

This was not the case with the mixed-race population in the nineteenth century, who shared a history with France itself. The black man who was not biracial, remaining as he did outside the history of France, could not demand recognition for his humanity.

Therefore, le noir as a literary personnage remained locked into one of the two paradigms assigned by the Enlightenment (either l'esclave royale, le bon nègre or some adaptation or combination of the two). The history of le mulâtre, on the other hand, shared the history of revolutionary France. An essential (and yet unrecognized) part of the French nation, marginalized due to French racism, le mulâtre was the quintessential Romantic character. The exploration of his psyche as a black man with white skin allowed Romantic writers to place black masculinity in confrontation with white masculinity. As I have shown in Chapter Three through Chapter Six of this dissertation, this confrontation took various forms. These forms ranged from deranged villains who either vowed vengeance on whiteness or became the tool of vengeance for former black slaves (Chapter Three) to mulatto males who entered into interracial romances (Chapter Six). In each of these representations, le mulâtre came into a confrontation with white masculinity that demanded recognition of his humanity. This could not be fully accomplished with le noir until the re-discovery and validation of African history in the early twentieth century. As such, le mulâtre serves as a "bridge" and a harbinger of 
sorts, both connecting the racial discourses of the Enlightenment to those of negritude and foreshadowing the revolt against these discourses (créolité).

In this dissertation, I have explored the several ways in which le mulâtre enters into confrontation with white masculinity and literary traditions to destabilize the discourse of race in French Romantic literature from the time of his appearance in the early nineteenth century to his disappearance in the mid-nineteenth century. The mulattos' search for agency and demand of recognition of his humanity connects all of the works that I have studied in this dissertation. By carefully examining the marginalization that le mulâtre experiences in each of these works in this dissertation with the search for identity in negritude demonstrates that le mulâtre can be read as a link connecting the lack of agency observed in la littérature négrophile with the modern aesthetic of blackness in negritude, which centers on a prise de conscience of blackness and a search for individual and collective black identity. 
${ }^{1}$ I examine the la littérature négrophile in detail in Chapter Two.

${ }^{2}$ La mulâtresse appeared with much more frequency in French literature, both before the Bourbon Restoration and after. Examples include the anonymously published La mulatresse comme il y a peu de blanches (1802), Amanda in Petrus Borrel's story Jacquez Barrou le charpentier (1833), Paquita in La fille aux yeux d'or (Honoré de Balzac, 1835), and the poetry of Charles Baudelaire.

${ }^{3}$ I discuss the importance of la littérature négrophile in depth in Chapter Two

${ }^{4}$ Atkinson, Geoffrey. The Sentimental Revolution, French Writers of 1690-1740. Seattle, University of Washington Press, 1965.

${ }^{5}$ As I argue in Chapter Two, the appearance and treatment of le mulâtre in French Romanticism and the evolution of la littérature négrophile must be analyzed in light of the readership of French Romanticism, a population that James Allen refers to as le menu peuple in his work "Popular French Romanticism" ${ }^{6}$ Hugo's treatment of the mulatto characters in Bug-Jargal is quite atypical. The mulatto phenotype in Western literature is usually one of exotic beauty.

7 "In the colonies the racial terminology could be even more complex, tracing blood back for seven generations. . . In Paris, such distinctions were largely irrelevant. The phrase gens de couleur (literally, "people of color") was used in French metropolitan legislation of the second half of the eighteenth century to cover all possible combinations of European and African ancestry." (Peabody 76)

8 "Qui oserait encore plaider la cause des Noirs après les crimes qu'ils ont commits?" Chateaubriand, Francois-René de. Le Génie du christianisme (1802), vol 2. Paris : Ernest Flammarion 1948.

${ }^{9}$ Gouges, Olympe de. L'Esclavage des noirs ou l'heureux naufrage (1789). Paris: Duchesne 1792

${ }^{10}$ Popkin, Jeremy. "The French Revolution's Other Island", in The World of the Haitian Revolution, Geggus, David $\mathrm{P}$ and Norman Fiering, eds.

${ }^{11}$ Sepinwall, Alyssa G. "The Specter of Sant-Domingue: American and French Reactions to the Haitian Revolution." in The World of the Haitian Revolution, Geggus, David P and Norman Fiering, eds.

${ }^{12}$ An example of this in Victor Hugo's historical novel Bug-Jargal, which places mulattoes at the center of the Saint-Domingue Revolution, citing that the white colonizers did not think the slaves capable of carrying out such a large-scale revolution on their own: "Ce n'est pas que les esprits même les plus prompts à s'alarmer, s'attendissent sérieusement des lors à la révolte des esclaves, on méprisait trop cette classe pour la craindre: mais il existait seulement entre les blancs et les mulâtres libres assez de haine pour que ce volcan si longtemps comprimé bouleversât toute la colonie au moment redoute où il se déchirerait." (Hugo 44)

${ }^{13}$ The image of a mulatto was assumed to be the child of a white father and a black mother. When I say the paternity was recognized, I do not refer to the claiming of paternity by an individual; I rather refer to the refusal of French nineteenth century literature to consider any other combination of interracial conception other than white father and black mother.

${ }^{14}$ The use of the term negritude in this dissertation is not to be confused with Cesarean negritude ideology, but rather is used as a translation of the word "blackness." Le mulâtre in nineteenth century French literature does not identify with and embrace his blackness, but rather is forced to negotiate racial identity in other ways.

"The nègre, in short, was primarily imagined as a man ... Outside of the African context, the term nègre generally evoked a subjected male human whose very essence was associated with slavery and the mechanical functioning of the colonial enterprise" (Curran 10) "For the most part the slave figure is male" (Lively 83)

${ }^{16}$ "Legal theorists in France notwithstanding, no serious colonial debate about slavery's legitimacy took place. No legal contradiction existed between not enslaving Frenchmen and enslaving Africans" (Boucher $157,158)$

17 "Romance recognizes characters; sentimentality creates recognition between groups that are not always already the same." (Festa 55)

${ }^{18}$ The negrophile literature of the Enlightenment did much to rehabilitate the image of blackness, but not always from an abolitionist standpoint. This does not place it outside the realm of negrophile literature nor of sentimental literature, as Lynn Festa notes: "Janus-faced, the sentimental can be used to argue 
both sides of a question; thus it is employed as a rhetorical strategy, by both proslavery writers and abolitionists, borrowed by supporters and adversaries of colonial trade alike" (Festa 15)

${ }^{19}$ The process of redundant humanization was also very popular in the visual arts of the eighteenth century. The best known example is of the medallion showing a black slave in chains kneeling under the inscription, "Am I Not a Man and a Brother?" reproduced in Anthony Benezet's Some Historical Account of Guinea (1788). See also the frontispice of Jean Baptite Labat's Nouveau voyage aux isles de l'ameriques (1742)

${ }^{20}$ It is of crucial importance to distinguish the mulatto, seen as the offspring of sexual license and libertinage between the black and white races, from le métis. Le métis, children of French settlers and the non-black indigenous population of French colonies, were welcomed into the French colonial enterprise as long as the indigenous individual converted to Catholicism and was married to the French settler by the Catholic Church. Under Louis XIV's Assimilationist policies, marriage of French settlers to non-black, indigenous women was encouraged. This was not the case with the mulatto, who was always considered a product of societal disorder.

21 "At some moment in the late eighteenth-century ... under the impact of translated English and German works, the French sentimental adventure story transmuted itself into yet another distinct genre, termed the roman noir, which appropriated genre markers from translated foreign literature while generally obeying local norms with regard to narrative structure and ideological content. This new form underwent further modifications as a result of the evolving social and political landscape in the wake of the restoration of the French monarchy during the 1820's and 1830's, at which point a new term was coined to describe it: the roman frénétique." (Hale, Terry. "French and German Gothic: the beginnings." IN The Cambridge Companion to Gothic Fiction, ed Hogle, Jerrold. New York, Cambridge University Press, 2002. p 63)

${ }^{22}$ Balzac may have had a writing partner, A. Lepoitevin de l'Egreville.

${ }^{23}$ Allen, Popular French Romanticism p 112

${ }^{24}$ The chemicals Féo mixes can also be read as a reference to the reported use of poisons during the Saint-Domingue uprising, which also was noted as a time of very frequent sexual attacks on white women by rebel slaves.

${ }^{25}$ Born Juan Victor Séjour Marourt Ferrand, Séjour was the son of François Louis Séjour Marcou, a free mulatto from Santo Domingo, and Eloisa Phillippe Ferrand, a free octoroon from New Orleans.

${ }^{26}$ In his book Neither White nor Black Yet Both, Werner Sollors reads the identity of the abusive person, described in the text as le gerant, as Alfred himself (165). The actual identity of the abusive person is ambiguous. In either case, the abuse of Jacques Chambo renders him unable to protect his sister from future abuses, which will become the role of the mulatto son.

${ }^{27}$ A slave was powerless in relation to another precisely because he had to depend exclusively on a single person for protection. (Patterson, 28)

${ }^{28}$ As I shall show in my analysis of Bug-Jargal, the law of partus sequitar ventrum helps establish an Oedipal triangle which placed the black or mulatto mother under the son's protection.

${ }^{29}$ The attentive reader will notice the phonetic similarity of the name of George's wife, Zélie to his mother, Laisa.

${ }^{30}$ Bongie provides an account of the mulatto as a "threateningly indeterminate identity." (Bongie 232)

${ }^{31}$ Two characters in Hugo's novel participate in what is now known as race-passing; the sang-melé whom $d$ 'Auverney duels after he has dared to dance with d'Auverney's fiancée Marie ( $p$ 47), and the battle-field captain who, surrounded by other white officers, insists that the Saint-Domingue uprising is the fault of the black slaves and not the mixed-race plantation owners ( $p$ 82).

${ }^{32}$ I examine Biassou's character in depth in Chapter Five of this dissertation, Le Mulâtre gothique.

${ }^{33}$ Tue mon père, je tuerai le tien.

${ }^{34}$ Leon Francois Hoffman (Le nègre romantique) and Pratima Prasad (Race and the French Colonial Imagination) both note the interest of le noir in the literature of the early nineteenth century ("a plethora of texts with black protagonists were published in the early part of the nineteenth century" Prasad 100) Both attribute this to several factors, such as memories of the Saint-Domingue revolution, the increase in 
abolitionist movement in the 1820 's, the 1823 poetry competition sponsored by the French Academy which declared slavery and abolition as a theme, the famous shipwreck of The Medusa in 1816, and the earthquake in Martinique in 1839. David O'Connell notes that several romantic writers portrayed le noir as a literary exercise during the 1820 's and 1830 's as the marginalization of the character and potential for rebellion made him a romantic subject ("The Black Hero in French Romantic Fiction," 518).

${ }^{35}$ In his book The Black Musketeer, Eric Martone observes that even though the setting of Dumas' novel George is in lle de France, present-day Mauritius, the images evoked by the novel are reminiscent of Saint-Domingue.

${ }^{36}$ Monique Ilboudo's novel Le Mal de Peau (2001) tells the story of a mulatto woman, born of an act of sexual violence by a white man, who as a young woman falls in love with a white man.

${ }^{37}$ In his book The Romantic Hero and his Heirs in French Literature, Lloyd Bishop explains that le mal du siècle, which is caused by History, must be distinguished from le vague des passions, which is more of a subjective, personal longing.

38 "Read in tandem, the memoir of the son and that of the father allow readers to index two specific representations of black masculine subjectivity and agency in a way that reveals how this subjectivity and agency come to be constructed in part as responses to white masculine agency, that is in response to specific institutions and practices of power. These implements of power include the theater of war and the prison cell, the latter posited as an echo of the institution of slavery . . black masculine agency establishes itself as an engagement with (if not necessarily as a resistance to) the practices of the white supremacist patriarchy in place in France during the first half of the nineteenth century." Saint-Aubin, Arthur. "Isaac Louverture's Memoires: A Nineteenth-Century Representation of Black Masculinity in the Name of the Father," Nineteenth-Century French Studies, vol 39 nos 1 \& 2, Fall-Winter $2010-2011$, pp 13 $-114$.

${ }^{39}$ The absence of Georges and Jacques Munier's mother allows Dumas' novel Georges to deal strictly with the issue of race alone. Race was established in French society in masculine terms. As Andrew Curran states in Anatomy of Blackness, the raced body was a male body (Curran 103)

40 "The essential fascination, the greatness of the man lay solely in his dandyism . . Barbey does away with apologies: to be merely a dandy, pure and exclusive in dedication to a pose, is for the first time a distinction." (Moers 262)

${ }^{41}$ I explore the theme of interracial romance and the male mulatto in depth in Chapter Six.

${ }^{42}$ In 1847, Paul Féval will explore the topic of race passing with his novel Le Mendiant Noir, in which would-be assassin Juan Carrel is willing to commit murder in order to keep his mixed-race heritage a secret. However, Paul Féval doesn't go as far as Dumas does in examining the familial, sociological, and economic aspects of race passing.

${ }^{43}$ Here, I refer to the shedding of the Neo-Classical boundaries of literature that dominated the first part of the nineteenth century. After 1830, French writers experienced more freedom to explore topics that did not offend the public sensibilities.

${ }^{44}$ " Déjà leurs mères parlaient de leur mariage sur leurs berceaux, et cette perspective de félicité conjugale, dont elles charmaient leurs propres peines, finissait bien souvent par les faire pleurer ... elles se consolaient en pensant qu'un jour leurs enfants, plus heureux, jouiraient à la fois, loin des cruels préjugés de l'Europe, des plaisirs de l'amour et du bonheur de l'égalité. » (Paul et Virginie 119)

${ }^{45}$ The theme of le couple domino surviving a tropical storm is also used in Le Docteur Noir (1846), a sevenact play written by Auguste Anicet-Bourgeois and Philippe Dumanoir. I have not included an analysis of Le Docteur Noir in this chapter due to the differences between analyzing a play and prose; however, the extreme popularity of the play attests to the interest the French public had in artistic representation of le couple domino during the July Monarchy.

46 "Un mulâtre est un nègre qui n'a pas de peau noire" (Toumson 147)

${ }^{47}$ The black electorate that the leaders of la Sociéte ethnologique anticipated did indeed take place. The 1848 abolition of slavery was accompanied by universal male suffrage. Several individuals of mixed-race were elected to l'Assemblé nationale. Temporarily suspended during the Second Empire, universal suffrage and colonial parliamentary representation was re-instituted with the Third Republic. 


\section{Bibliography}

Allen, James Smith. Popular French Romanticism: Authors, Readers, and Books in the $19^{\text {th }}$ Century. Syracuse: Syracuse University Press, NY 1981. Print.

Anolik, Ruth B. and Douglas L. Howard, eds. The Gothic Other: Racial and Social Constructions in the Literary Imagination. Jefferson, N.C.: McFarland and Company Publishers, INC 2004. Print.

Antoine, Regis. Les écrivains français et les Antilles: des premiers pères blancs aux surréalistes noirs. Paris : G.P. Maisonneuve et LaRose, 1978. Print.

Arnold, A. James. "Recuperating the Haitian Revolution in Literature: From Victor Hugo to Derek Walcott" IN Tree of Liberty: Cultural Legacies of the Haitian Revolution in the Atlantic World. Charlottesville : University of Virginia Press 2008. Print.

Aubert, Guillaume. "“The Blood of France": Race and Purity of Blood in the French Atlantic World." The William and Mary Quarterly 61.3 (Jun 2004) 439 - 478. Print.

Bandèche, Maurice. Balzac. Paris : Julliard 1980. Print.

Barnes, Elizabeth. Incest and the Literary Imagination. Gainesville, Florida: University Press of Florida, 2002. Print.

Belluscio, Steven. To Be Suddenly White: Literary Realism and Racial Passing. Columbia: University of Missouri Press, 2006

Benot, Yves and Marcel Dorigny, eds. Rétablissement de l'esclavage dans les colonies françaises 1802. Paris : Maisonneuve et LaRose, 2003. Print.

Bentley, Nancy. "White Slaves: The Mulatto in Antebellum Fiction." American Literature 
65.3 (Sept 1993) 501 - 522. Print.

Berlin, Isaiah. The Roots of Romanticism. Princeton, Princeton University Press, 1999.

Print.

Bernard, Claudie. "Georges," or the 'Mixed-Blood' Settles Scores" in The Black

Muskateer: Reevaluating Alexandre Dumas within the Francophone Word. ed

Eric Martone. Newcastle: Cambridge Scholars Publishing, 2011. Print.

Betz, Dorothy M. “Bernadin's Paul et Virginie." Explicator (Spring 1995) 53. 3138 -

141. Print.

Black, Lynette C. "Baudelaire as Dandy: Artifact and the Search for Beauty." Nineteenth-

Century French Studies 17. 1 \& 2 (Fall Winter 1988 - 1989) 187 - 195. Print.

Bok, Christian. "The Monstrosity of Representation: Frankenstein and Rousseau."

English Studies in Canada 18 (1992): 415 - 432. Print.

Bongie, Chris. Islands and Exiles: The Creole Identities of Post/Colonial Literature.

Stanford: Stanford University Press 1998. Print.

Botting, Fred. "In Gothic Darkly: Heterotopia, History, Culture." IN A New Companion to the Gothic Punter, David ed. West Sussex 2012. Print.

Boucher, Philip. France and the American Tropics to 1700: Tropes of Discontent? Baltimore: John Hopkins University Press 2008. Print.

Boulle, Pierre H. Race et esclavage dans la France de l'Ancien Régime. Paris : Perrin 2007. Print.

Bremond, Claude; Landy, Joshua and Pavel, Thomas. Thematics: New Approaches. Albany: State University of New York Press 1995. Print. 
Bruhm, Steven. Gothic Bodies: The Politics of Pain in Romantic Fiction. Pennsylvania: University of Pennsylvania Press, 2003. Print.

Bruzelius, Margaret. Romancing the Novel: Adventure from Scott to Sebald. Lewisberg: Bucknell University Press 2007. Print.

Bryant, Kelly Duke. "Black But Not African: Francophone Black Diaspora and the Revue des Colonies, 1834 - 1842." International Journal of African Historical Studies 40.2 (2007) 251 - 282. Print.

Burt, E.S. "A Cadaver in Clothes: Autobiography and the Dandy Baudelaire," Romanic Review vol 1 (2005) 19 - 39. Print.

Burton, Richard D. E. La Famille Coloniale: La Martinique et la Mère Patrie, 1789 - 1992. Paris : I’Harmattan 1994. Print.

Butler, Judith. Bodies That Matter: On The Discursive Limits of "Sex." New York, NY: Routledge 1993. Print.

Camiscioli, Elisa. Reproducing the French Race: Immigration, Intimacy, and Embodiment in the Early Twentieth Century. Durham: Duke University Press 2009. Print.

Case, Frederick I. The Crisis of Identity: Studies in the Guadeloupian and Martinican Novel. Sherbrooke: Naaman 1985. Print.

Chalaye, Sylvie. Du Noir au Nègre : l'image du Noir au théâtre de Margarite de Navarre à Jean Genet (1550 - 1960), Paris : I'Harmattan, 1998. Print.

Charlton, Donald G. The French Romantics: Vol 2. New York: Cambridge University Press 1984. Print.

Chollet, Roland. “Du premier Balzac à la mort de Saint-Aubin: Quelques remarques sur le 
lecture introuvable." L’Année balzacienne 8 (1987) : 7 - 20. Print.

Cohen, Margaret. The Sentimental Education of the Novel. Princeton: Princeton University Press, 2002. Print.

Cohen, William B. The French Encounter with Africans: White Response to Blacks, 1530 1880. Bloomington: Indiana University Press 1980. Print.

Cohen, Yehuda. The French: Myths of Revolution. Portland: Sussex Academic Press 2011. Print.

Cook, Malcolm C. "Harmony and Discord in Paul et Virginie." Eighteenth-Century Fiction 3.3 (April 1991) $205-216$. Print.

Cooper, Frederick and Ann L. Stoler, eds. Tensions of Empire: Colonial Cultures in a Bourgeois World. Berkeley: University of California Press 1997. Print.

Curran, Andrew S. The Anatomy of Blackness: Science and Slavery in an Age of Enlightenment. The John Hopkins University Press 2011. Print.

Cutter, Martha. "Sliding Significations: Passing as Narrative and Textual Strategy in Nella Larsen's Fiction," IN Passing and the Fictions of Identity Ginsberg, Elaine K ed. Durham: Duke University Press 1996. Print.

Daut, Marlene L. "'Sons of White Fathers' Mulatto Vengeance and the Haitian Revolution in Victor Séjour's 'The Mulatto'” Nineteenth Century Literature 65.1 (June 2010) 1 - 37. Print.

Davis, Thadious M. Nella Larsen: Novelist of the Harlem Renaissance. Baton Rouge: Louisiana State UP, 1994. Print.

Denby, David J. Sentimental Narrative and the Social Order in France, $1760-1820$. New 
York:Cambridge University Press 1994.Print.

Didier, Beatrice. Écrire la Révolution (1789 - 1799). Paris: Presses Universitaires de France 1989. Print.

Dominguez, Virginia R. White by Definition: Social Classification in Creole Louisiana. New Brunswick: Rutgers UP, 1988. Print.

Doyle, Laura. "The Folk, the Nobles, and the Novel: The Racial Subtext of Sentimentality." Narrative 3.2 (May 1995) 161 - 167. Print.

Dubois, Laurent. A Colony of Citizens: Revolution and Slave Emancipation in the French Caribbean 1787 - 1804. Chapel Hill: University of North Carolina Press, 2007. Print.

- - . Avengers of the New World: The Story of the Haitian Revolution. Massachusetts: Harvard University Press, 2005. Print.

Dubois, Laurent. “La République Métissée: Citizenship, Colonialism, and the Borders of French History," Cultural Studies 14.1 (Winter 2000) 15 - 34. Print.

Dumas, Alexandre. Georges. Editions Gallimard, 1974. Print.

Ehlers, Nadine. Racial Imperatives: Discipline, Performativity and Struggles Against Subjugation. Bloomington: Indiana University Press, 2012. Print.

Ellis, Markman. The History of Gothic Fiction. Edinburg: Edinberg University Press 2000. Print.

Evans, David. Social Romanticism in France 1830 - 1848. New York: Octagon Books 1969. Print.

Ezra, Elizabeth. The Colonial Unconscious: Race and Culture in Interwar France. Ithaca: 
Cornell University Press 2000. Print.

Festa, Lynn. Sentimental Figures of Empire in Eighteenth-Century Britain and France.

Baltimore: The John Hopkins University Press 2006. Print.

Flannigan, Arthur. "Alphonse de Lamartine's Toussaint Louverture and the Staging of White Masculinity." Nineteenth-Century French Studies 35.2 (Winter 2007) 333 351. Print.

Ford, Rebecca. "Reading Bernadin de Saint-Pierre: Letters and the Book of Nature." Nottingham French Studies 48.3 (Autumn 2009) Print.

Foucault, Michel. "Utopias and Heterotopias." IN Leach, N (ed). Rethinking Architecture: A Reader in Cultural Theory. London: Routledge 1997. Print.

Furst, Lilian R. "The Romantic Hero, or Is He an Anti-Hero?" Studies in the literary Imagination 9.1 (Spring 1976) 53 - 67. Print.

Gallagher, Catherine. “Oroonoko's Blackness," IN Aphra Behn Studies, Todd, Janet ed. Melbourne: Cambridge University Press 1996. Print.

Garber, Frederick. "Self, Society, Value, and the Romantic Hero." Comparative Literature 19.4 (Autumn 1967) 321 - 333. Print.

Garraway, Doris L. The Libertine Colony: Creolization in the Early French Caribbean. Durham: Duke University Press 2005. Print.

Garrigus, John D. Before Haiti: Race and Citizenship in French Saint-Domingue. Palgrave MacMillan 2006. Print.

Geggus, David Patrick and Norman Fiering. The World of the Haitian Revolution. Bloomington: Indiana University Press 2009. Print. 
Gifford, Paul. Love, Desire and Transcendence in French Literature: Deciphering Eros. Burlington: Ashgate Publishing CO 2005. Print.

Gilroy, Paul. The Black Atlantic: Modernity and Double Consciousness. Cambridge: Harvard University Press 1993. Print.

Ginsberg, Elaine K. Passing and the Fictions of Identity. Durham: Duke University Press 1996. Print.

Giraud, Raymond. The Unheroic Hero in the Novels of Stendhal, Balzac and Flaubert. New Jersey: Rutgers University Press 1957. Print.

Glinoer, Anthony. "Du monstre au superhomme: Le Roman frénétique de la Restauration." Nineteenth Century French Studies, 34. 3 \& 4 (Spring - Summer 2006) 223 - 234. Print.

Goodwin, Stephan. Africa in Europe: Interdependencies, Relocations and Globalization. Plymouth: Lexington Books 2009. Print.

Grana, César. Bohemian versus Bourgeois: French Society and the French Man of Letters in the Nineteenth Century. New York: Basic Books 1964. Print.

Grigsby, Darcy Grimaldo. "Revolutionary Sons, White Fathers, and Creole Difference : Guillaume Guillon-Lethière's 'Oath of the Ancestors' (1822)." Yale French Studies $101(2001) 201-226$. Print.

Grove, Richard. Green Imperialism: Colonial Expansion, Tropical Island Edens and the Origins of Environmentalism 1600 - 1860. Cambridge: Cambridge University Press 1995. Print.

Hadlock, Philip. "The Other Other: Baudelaire, Melancholia, and the Dandy." 
Nineteenth-Century French Studies 30.1 \& 2 (2001) 58 - 67. Print.

Hale, Terry. "French and German Gothic: The beginnings," IN The Cambridge Companion to Gothic Fiction. Hogle, Jerrold E. ed. New York, N.Y.: Cambridge University Press 2002. Print.

Hamilton, James. "The Anxious Hero in Chateaubriand's René," Romance Quarterly 34. 41987 415- 422. Print.

Hamm, Jean-Jacques. "Egotism and Narcissism : Avatars of the Masculine Imagery in Nineteenth-Century French Literature" IN Echoes of Narcissus, Spasses, Lieve and Selous, Tresta, eds. New York, NY: Berghahn Books, 2000. Print.

Hetherington, Kevin. The Badlands of Modernity: Heterotopia and Social Ordering. New York: Routledge, 1997. Print.

Hoffman, Léon-François. Le nègre romantique: personnage littéraire et obsession collective. Paris: Payot 1973. Print.

Hook, Derek. Foucault, Psychology and the Analytics of Power. New York, N.Y. : Palgrave MacMillan 2007. Print.

Hunt, Lynn. The Family Romance of the French Revolution. Berkeley: University of California Press 1992. Print.

Hurley, Kelly. “British Gothic Fiction, 1885 - 1930." IN The Cambridge Companion to Gothic Fiction. Hogle, Jerold E. (ed). New York, N.Y. : Cambridge University Press 2002. Print.

Jack, Belinda E. Negritude and Literary Criticism: The History and Theory of "NegroAfrican" Literature in French. London : Greenwood Press 1996. Print. 
Jackson, Cassandra. Barriers between US: Interracial Sex in Nineteenth-Century American Literature. Bloomington: Indiana University Press 2004. Print.

James, C . L . R. The Black Jacobins: Toussaint L'Ouverture and the San Domingo Revolution. New York: Vintage Books 1989. Print.

Jarden, Andre and Tudesq, Andre-Jean. Restoration and Reaction, 1815 -1848. trans. Foster, Elborg. London: Cambridge University Press 1983. Print.

Jennings, Lawrence C. French Anti-Slavery: The Movement for the Abolition of Slavery in France 1802 - 1848. New York: Cambridge University Press 2000. Print.

Jennings, Lawrence. "Slavery and the Venality of the July Monarchy Press." French Historical Studies 17 (1992) 957 - 978. Print.

Jenson, Deborah. Trauma and Its Representations: The Social Life of Mimesis in PostRevolutionary France. Baltimore: The John Hopkins University Press 2001. Print. ---- “Editor's Preface: Nineteenth Century postcolonialités at the Bicentennial of the Haitian Independence." Yale French Studies 107 (2005) 2 - 3. Print.

Joffrey, Nora ed. Gender, Race and Religion in the Colonization of the Americas: Women and Gender in the Early Modern World. Burlington: Ashgate Publishing 2007. Print.

Kadish, Doris Y., ed. Slavery in the Caribbean Francophone World: Distant Voices, Forgotten Acts, Forged Identities. Athens: University of Georgia Press, 2000. Print.

Kapor, Vladimir. "Shifting Edenic Codes: On Two Exotic Visions of the Golden Age in the Late Eighteenth Century," Eighteenth-Century Studies 41.2 (2008) 217 - 230. 
Print.

Khair, Tabish. The Gothic, Postcolonialism and Otherness: Ghosts from elsewhere. New York: Palgrave MacMillan 2009. Print.

Kleinberg, Ethan. Kojève and Fanon: The Desire for Recognition and the Fact of Blackness. In French Civilization and Its Discontents: Nationalism, Colonialism, Race. Stovall, Tyler and Georges Van Den Abbeele, eds. New York: Lexington Books (2003) $115-128$. Print.

Kreuger-Enz, Molly. "The Mulatto as Island and the Island as Mulatto in Alexandre Dumas's "Georges,"”" The French Review 80.2 (Dec 2006) 383 - 394. Print. Kramer, Leonie. "Utopia as Metaphor." In Utopias: Papers from the Annual Symposium of the Australian Academy of the Humanities, Kamenka, Eugene, ed. 134 - 144. Melbourne: Oxford University Press, 1987. Print.

Krueger-Enz, Molly. "The Mulatto as Island and the Island as Mulatto in Alexandre Dumas's “Georges"”" The French Review 80.2 (Dec 2006) 383 - 394. Print.

---. "Who Belongs to Whom? Codes, Property, and Ownership in Madame Charles Reybaud's “Les Epaves” Nineteenth-Century French Studies 39. 3 \& 4 (Spring-Summer 2011). Print.

Lee, Debbie. Slavery and the Romantic Imagination. Pennsylvania: University of Pennsylvania Press, 2002. Print.

Little, Roger. Between Totem and Taboo: Black Man, White Woman in Francographic Literature. Exeter: UK University of Exeter Press 2001. Print.

Lively, Adam. Masks : Blackness, Race and the Imagination. New York: Oxford University 
Press 2000. Print.

Loombia, Ania. Colonialism / Postcolonialism. London : Routledge, 1998. Print.

MacCloy, Shelby. The Negro in the French West Indies. Lexington: University of Kentucky Press 1966. Print.

Maignan-Claverie, Chantal. Le Métissage dans la Littérature des Antilles françaises: Le complexe d'Ariel. Paris : Editions Karthala 2005. Print.

Malchow, H. L. Gothic Images of Race in Nineteenth-Century Britain. Stanford: Stanford University Press 1996. Print.

Martone, Eric. The Black Muskateer : Reevaluating Alexandre Dumas within the francophone world. Newcastle upon Tyne: Cambridge Scholars Publishing 2011. Print.

Miller, Chris. The French Atlantic Triangle: Literature and Culture of the Slave Trade. London: Duke University Press 2008. Print.

Moers, Ellen. The Dandy. New York: The Viking Press 1960. Print.

Morrison, Toni. Playing in the Dark: Whiteness and the Literary Imagination. New York, NY: Vintage 1993. Print.

Moses, Claire Goldberg and and Leslie Raben. Feminism, Socialism, and French Romanticism. Bloomington: Indiana University Press 1993. Print.

Noël, Erick. Etre noir en France au XVIIle siècle. Paris: Editions Tallandier 2006. Print. O’Connell, David. "The Black Hero in French Romantic Fiction." Studies in Romanticism 12.2 (Spring 1973) $516-529$. Print.

Ormerod, Beverly. "The Representation of Women in French Caribbean Fiction." IN An 
Introduction to Caribbean Francophone Writing: Guadeloupe and Martinique, 101 - 118 Haigh, Sam ed. Oxford: Berg 1999. Print.

Pasco, Allan H. Sick Heroes: French Society and Literature in the Romantic Age, $1750-$ 1850. Devon: University of Exeter Press 1997. Print.

Paulson, Ronald. "Gothic Fiction and the French Revolution." ELH 48.3 (Autumn 1981) 532 - 554. Print.

Peabody, Sue and Tyler Stovall, eds. The Color of Liberty: Histories of Race in France. Durham: Duke University Press 2003. Print.

Perry, Ruth. "Incest as the Meaning of the Gothic Novel," The Eighteenth Century 39.3 (Fall 1998) $261-278$. Print.

Peyre, Henri. What is Romanticism? trans Roda Roberts. Alabama: The University of Alabama Press 1977. Print.

Piquenard, Jean-Baptiste. Adonis, ou Le Bon Nègre: anecdote coloniale. Paris, 1836. Print.

Portes, Laurent. "Utopia and Nineteenth-Century French Literature." In Utopia: The Search for the Ideal Society in the Western World, 241 - 247. Roland Schaer, Gregory Clays, and Lyman Tower Sargent, eds. New York: Oxford University Press 2000. Print.

Prasad, Pratima. Colonialism, Race, and the French Romantic Imagination. Routledge Publishing 2009. Print.

Praz, Mario. The Romantic Agony. London: Oxford University Press 1951. Print. Prungnaud, Joëlle. Gothique et Décadence, Recherches sur la continuité d'un mythe et 
d'un genre au XIXe siècle en Grande-Bretagne et en France. Paris : Honoré Champion, 1997. Print.

Pucci, Suzanne R. "Snapshots of Family in the French Eighteenth Century: The Case of Paul et Virginie," Studies in Eighteenth-Century Culture 37 (2008) 89 - 118. Print.

Punter, David. "Narrative and psychology in Gothic fiction." IN Gothic Fictions: Prohibition / Transgression. Graham, Kenneth W., ed. New York AMS.

Racault, Jean-Michel. Mémoires du Grand-Océan: des relations de voyages aux littératures francophones de l'Océan Indien. Paris : Presses de l'Université ParisSorbonne 2007. Print.

Racault, Jean-Michel. “Virginie entre la nature et la virtue: Cohésion narrative et contradiction idéologiques dans Paul et Virginie," Dix-huitième siècle 18 (1986) 389 - 404. Print.

Reinhardt, Catherine A. Claims to Memory: Beyond Slavery and Emancipation in the French Caribbean. New York, NY : Berghahn Books 2006. Print.

Ridge, George Ross. The Hero in French Romantic Literature Atlanta: University of Georgia Press 1959. Print.

Rioux, Jean-Claude. "Crime, nature et société dans le roman de la Restauration." Romantisme, Revue du dix-neuvième siècle. 52 (1986) 4 - 16. Print.

Roberts, Kathleen Glenister. Alterity and Narrative: Stories and the Negotiation of Western Identities. New York: State University of New York Press 2007. Print. Rossard, Janine. "La Mort Mystérieuse de Virginie." The French Review 42.3 (Feb 1969) 409 - 418. Print. 
Sade, Donatien Alphonse Françoise de. "Reflections on the Novel." IN The 120 Days of Sodom and Other Writings, trans. Austryn Wainhouse and Richard Weaver 108 109. London: Arrow Books 1991. Print.

Saint-Aubin, Arthur F. “Isaac Louverture's Memories: A Nineteenth-Century Representation of Black Masculinity in the Name of the Father." NineteenthCentury French Studies, 39. 1 \& 2 (Fall - Winter 2010 - 2011) 11 - 32. Print.

Saint-Aubin, Arthur F. "Testeria: The Dis-ease of Black Men in White Supremacist, Patriarchal Culture." Callaloo, vol 17. 4 (Autumn 1994) 1054 - 1073. Print. Sauvigny, Guillaume de Bertier de. The Bourbon Restoration. trans Case, Lynn M. Philadelphia: The University of Pennsylvania Press 1966. Print.

Seeber, Ed. Anti-Slavery Opinion in France During the Second Half of the Eighteenth Century. Baltimore: The John Hopkins University Press 1937. Print.

Sepinwall, Alyssa Goldstein. "The Specter of Saint-Domingue: American and French Reactions to the Haitian Revolution." in The World of the Haitian Revolution, Geggus, David Patrick and Norman Fiering, eds. Indianapolis: Indiana University Press 2009. Print.

Seshadri-Crooks, Kalpani. Desiring Whiteness: A Lacanian Analysis of Race. London: Routledge 2000. Print.

Schloss, Rebecca Hartkopf. "The February 1831 Slave Uprising in Martinique and the Policing of White Identity." French Historical Studies 30.2 (Spring 2007) 203 - 236 Print.

---. Sweet Liberty: The Final Days of Slavery in Martinique. Pennsylvania: University of 
Pennsylvania Press 2009. Print.

Schoelcher, Victor. Abolition de l'esclavage: examen critique du préjugé contre la couleur des Africains et des sang-mêlés. Paris : Pagnere, 1840.

Smith, Andrew. Gothic Literature. Edinberg: Endinberg University Press 2007. Print. Soja, Edward W. "Heterotopologies: A Remembrance of other spaces in the citadel L.A." IN Postmodern Cities and Spaces. Watson, S and Gibson, K. (eds) Oxford, Blackwell

Spaas, Lieve. "Paul et Virginie: The Shipwreck of an Idyll." Eighteenth-Century Fiction 13.2 \& 3 (Jan - April 2001) $315-324$. Print.

Spitzer, Alan B. The French Generation of 1820. Princeton: Princeton University Press 1987. Print.

Stanford, Raney. "The Romantic Hero and That Fatal Selfhood," The Centennial Review 12.4 (Fall 1968) $430-454$. Print.

Stanton, Doman C. The Aristocrat as Art: A Study of the Honnête Homme and the Dandy in Seventeenth- and Nineteenth-Century French Literature. New York: Columbia University Press 1980. Print.

Stinchcombe, Arthur L. Sugar Island Slavery in the Age of Enlightenment. Princeton: Princeton University Press 1995. Print.

Stovall, Tyler and Georges Van Den Abbeele, eds. French Civilization and Its Discontents: Nationalism, Colonialism, Race. New York: Lexington Books 2003. Print. Taylor, Patrick. The Narrative of Liberation : Perspectives on Afro-Caribbean Literature, 
Popular Culture, and Politics. Ithaca and London : Cornell University Press 1989.

Print.

Toumson, Roger. Mythologie du métissage. Paris : Presses Universitaires de France 1998. Print.

Turner, Victor. The Ritual Process. New York: Aldine de Gruyter 1995. Print.

Waller, Margaret. The Male Malady: Fictions of Impotence in the French Romantic Novel. New Jersey: Rutgers University Press 1993. Print.

Ward, Patricia A. "The Political Evolution of Victor Hugo's Gothic Vision." Modern Language Quarterly 3.34 (September 1973) 272 - 282. Print.

Weigman, Robyn. American Anatomies: Theorizing Race and Gender. Durham: Duke University Press 1995. Print.

Woelff, Larry and Marco Cipolloni, eds. The Anthropology of the Enlightenment. Stanford: Stanford University Press 2007. Print.

Yee, Jennifer. Exotic Subversions in Nineteenth-Century French Fiction. London: Legenda Publishing 2008. Print.

---. "Métissage in France: A Postmodern Fantasy and Its Forgotten Precedents." Modern and Contemporary France 11.4 (2003) 411 - 425. Print.

---. "Neither Flesh nor Fowl: “Métissage" in fin-de-siècle French Colonial Fiction," L’Esprit Créateur 38.1 (Spring 1998) 46 - 56. Print.

Young, Robert. White Mythologies: Writing History and the West. London: Routledge 1990. Print. 
VITA

Huie Tomaz Cunningham completed his Bachelor of Arts in Physiology with a minor in French from Southern Illinois University at Carbondale in 1990. After serving eight years in the United States Army as a paramedic and French translator, he received an honorable discharge and returned to Southern Illinois University at Carbondale to pursue graduate studies. He completed his Master of Arts in Foreign Languages and Literatures and Teaching English as a Second Language in August 2003. His research project, entitled "Anti-Semitism in France from Charlemagne to Vichy," traced the history of French Jewry from France's beginnings as a nation to France's collaboration with Nazi Germany during World War II. His research interests in Linguistics focused on second-language acquisition for adults.

After several years as an unclassified graduate student, he formally enrolled in the Romance Languages Ph.D. program at the University of Missouri in August 2007. His dissertation focuses on the various representations of blackness in French literature in the eighteenth and nineteenth centuries. He has also completed a graduate minor in Black Studies. His teaching and research interests include Eighteenth and NineteenthCentury French Literature, The French Short Story, Masculinity Studies, and French 
history and civilization. He is currently an Instructor of French at Jackson State University in Jackson, Mississippi and teaches courses in Elementary French (FR 101 and FR 102) and French History and Civilization (FR 230, FR 231, FR 430 and FR 431). 